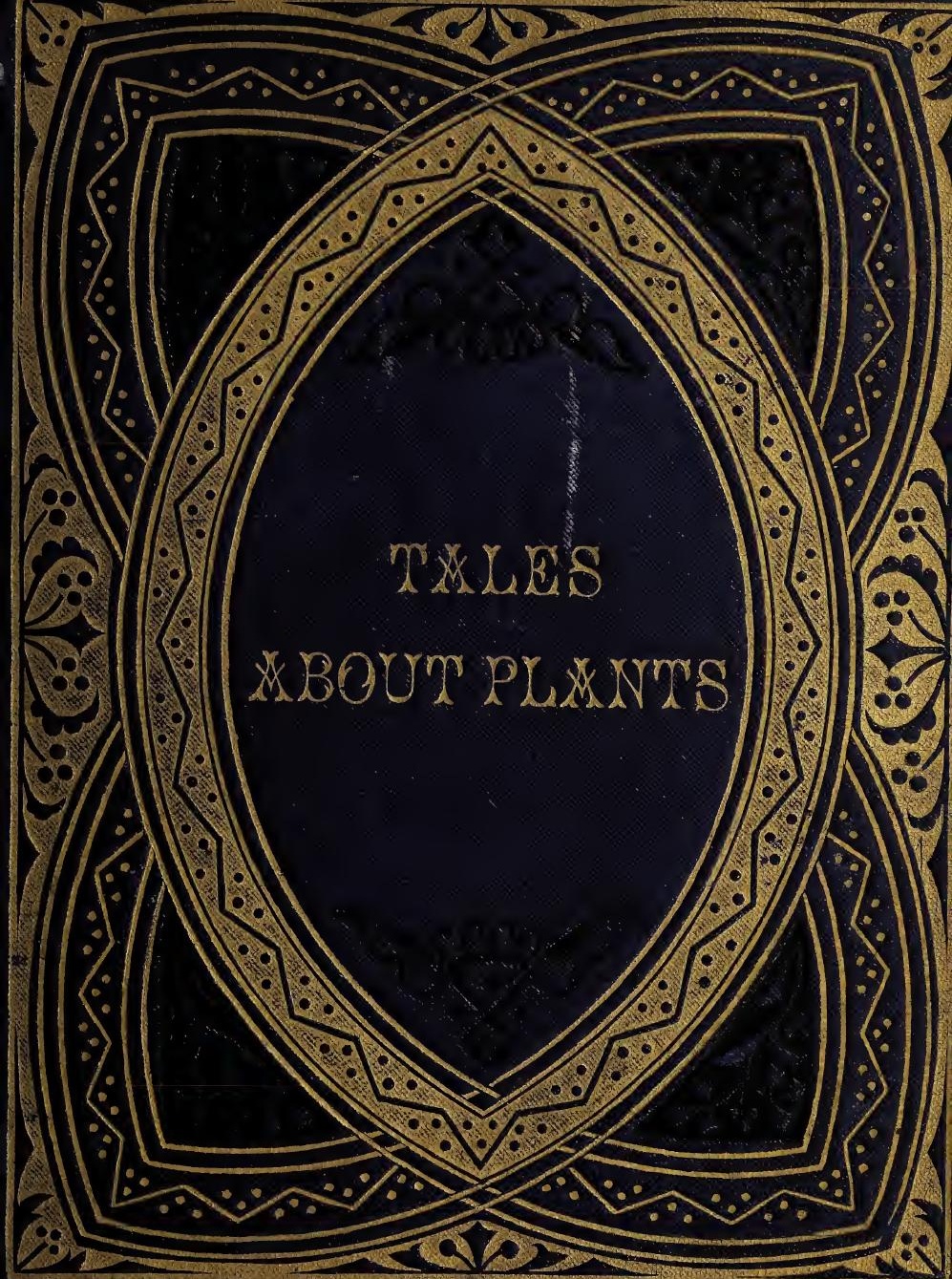




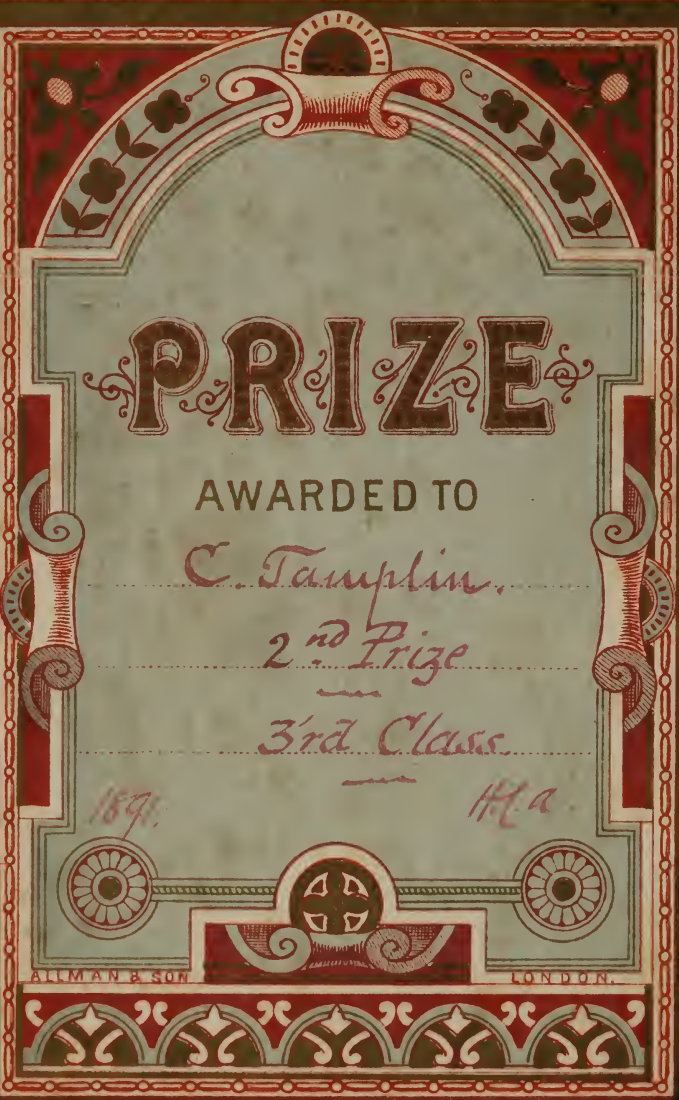


i, gCrion froad,

:.ni: 3ton-01-Thames
6. Gordon Poad.

\section{TALES ABOUT PLANTS.}


$7 \quad 190 \% 9$ 


\section{'TALES ABOUT' PLANTS.}

BY PETER PARLEY,

AUTHOR OF TALES ABOU' ANIMALS, TALES ABOUT EUROYE, ASIA, ETC.

\section{WITH NUMEROUS ENGRAVINGS.}

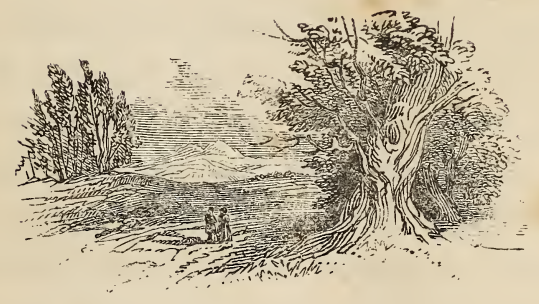

LONDON: WILLIAM TEGG. 
(n)

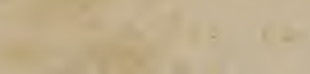

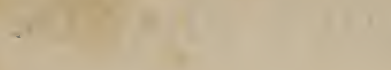

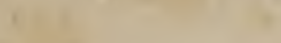

$-1-$

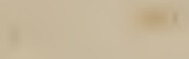

$\sqrt{2}$

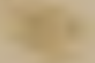

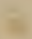

$\sqrt{2}$

11.

1

$=$

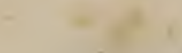

$-$

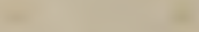

$-$

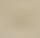

$1+1$

. 


\section{PREFACE.}

PETER PARLEY TO HIS YOUNG FRIENDS.

Having already told you all I know about animals, I thought you might next like to hear something of the other branches of natural history, and as I know of none more interesting than that relating to plants, I am now going to tell you all I know about them. Perhaps you will think that you know enough about plants already, because you have all of you seen oaks and elms, and flowers and vegetables; but there are many things about plants, of which I suspect you know nothing, and some of these you will find in the little book now before you. Plants are indeed interesting objects of study ; they are, like animals, endowed with life, and in this they 
differ from the rocks and stones around them; but their life is more feeble than that of animals, and their powers more limited. They cannot move about from place to place; they can neither bark like a dog, nor sing like a bird; but still, low as they rank in the scale of creation, they show the power and wisdom of their Almighty Creator as forcibly as the construction of the human frame itself. I shall tell you much about them that I think you will like to know, particularly of their native countries, their habits, and the persons who discovered them. I shall also tell you about the products of plants; most of which you have in daily use, though probably without thinking much about their origin. Tea, sugar, liquorice, and tamarinds are all products of plants ; as are muslin and cambric, and many other things that you see and use every day. I shall tell you a great deal about these things, and I shall endeavour as much as I can to make my book entertaining to you. I wish also to make it instructive and useful; and for this 
reason I shall not only tell you all I know about each plant separately, but I shall arrange all the plants I speak of, according to what botanists call the natural system; in which those plants are classed together, which bear a natural resemblance to each other. This you will find very useful, as it will enable you to guess something: about the nature of a plant the moment you see it; and, at any rate, it will show you what plants it is most prudent to shun, from the probability of their being poisonous. Botany is in itself a very comprehensive science, and one which it will require much time and study to understand; but this little book will shew you the first step towards acquiring some knowledge of it. I have here brought you into a fertile country, and opened a pleasant path before you, but it depends upon yourselves whether you will follow it to your advantage. No difficulty, however, will present themselves to prevent you from studying the great book of nature, which lies, as it were, open before you. The earth 
teems with beauty; and every bank is covered with objects which only require to be seen to excite your wonder and admiration; but which, if not pointed out, you would probably suffer to pass by unnoticed. In the following pages I have endeavoured to prevent this from being the case; and if I have succeeded in opening your eyes to any natural beauties, which would otherwise have passed unseen, and in making you feel more grateful to the Supreme Being, who has created all these wonders, I shall be satisfied, and my end will have been fully answered. 


\section{CONTENTS.}

Chapter

1. Peter tells about the different kinds of Clematis, or Virgin's Bower, and Traveller's Joy. Of the Use the French Beggars make of the latter. Peter also tells of the different kinds of Anemone, with the Story of M. Bachelier; and of the Hepatica . .

eter tells about the Meadow Rue and Marsh Marigold. May Games. The Ranunculus, Ficaria, Globe Flower, Winter Aconite, Christmas Rose, Flos Adonis, and Peony. History of the Chinese Peony. Botanical Collectors. Love in a Mist, Columbine, Monkshood, and Larkspur . . . . . . 16

3. The Story of Douglas, the Botanical Collector . . 35

4. Peter tells about the different kinds of Poppy. Opium, and the mode of gathering it. Poppy Oil, and the mode of collecting of the Poppy Seeds for making it in Belgium. The Prickly Poppy; the Welsh Poppy; the Eschscholtzia; the Horned Poppy; and the greater Celandine. Qualities of the Order Papavaraceæ . . . . . . . . . . . 48

5. The Fumitory Tribe ; the Water Lily Tribe; the Nutmeg Tree. The Magnolia Tribe. History of the Magnolia of Mallardiere . . . . . . .

6. Umbelliferous Plants. Story of Peter the Wild Boy. Story of the shipwrecked Sailors. Rapid Growth of the Siberian Cowparsnip . . . . . . . . 79

7. The Ivy. Gooseberries and Currants. The Barberry. The Vine. Gathering the Grapes and making 
Chapter

Wine. Drying Raisins and Currants. The VirPage ginian Creeper, or Five-leaved Ivy. The Pitcher Plant, and the Evening Primrose Tribe . . . . 98

8. The Myrtle Tribe. Story of the French Abbé. The Voyage to Dieppe. The Clove and other Spices. The Myrtacea of New Holland . . . . . . 122

9. Pomegranate. Brazil Nuts. Garden Syringa. The Witch Hazel. Dogwood. The Aucuba, or Japan Laurel. Misletoe. Superstitions respecting this Plant. Cucumber Tribe. Indian Fig Tribe. Cochineal Insect. Fig Marigold Tribe. Ice Plant. Caper Plant. Mignionette, Heartsease, and Violet 148

10. The Plants belonging to the Cruciferæ. The Cabbage Tribe. Mode of making Sauer Krout. Mustard and Cress. Sea Kale. Radish. Cruciferous Flowers, and other Plants belonging to the Order . . . 172

11. The Passion Flower. St.John's Wort, and other species of Hypericum. The Camellia. The Tea Plant. The Maple and Sycamore. The Dool Tree of Cassilis

13. The Horse Chestnut. Flax. The Cotton Plant, and other Plants belonging to the Mallow Tribe. The Rock Rose Tribe. The Lime Tree. The Mahogany Tribe. Satin Wood. The Bead Tree, Pride of India, and Indian Lilac. Purple Willow Herb, and Henna. Oranges and Lemons. The Jujube and other Plants belonging to the Buckthorn Tribe. Plants belonging to the Crowberry, Staff Tree, and Bladder Nut Tribes. The Roman Catholic Rosary 208

14. The Box Tree. Other Plants belonging to the Order Euphorbiaceæ; Castor Oil Plant; and Brazilian Indian Rubber Tree. Calandrinia. Pinks and Carnations. Other Plants of the Natural Order Silenaceæ. The Tamarisk Tree. The Rue Tribe. 
Chapter

The Geranium Tribe. The Balsam Tribe. The Garden Nasturtium: The Wood Sorrel Tribe . . 237

15. The Rose Tribe, including Roses, Brambles, Strawberries, \&c. Apples, Crabs, Pears. The Mountain Ash, the White Beam Tree, the Quince, and the Medlar. The Hawthorn. Almonds, Peaches, Nectarines, and Apricots. Plums and Cherries. The Feast of the Cherries at Hamburgh. The common and Portugal Laurels . . . • . 260

16. Beans and Peas. Sweet Peas. Kidney Beans. Lupines. Laburnum. Broom. False Acacia or Locust. Gleditschia. Kentucky Coffee Tree. Acacias. Gum Arabic. Liquorice. Tamarinds. Indigo. Rice Paper. Saintfoin, Lucern, and Clover 289

17. The Saxifrage Tribe, London Pride, and Hydrangea. The House Leek Tribe. The Turpentine Tribe. The Nettle Tribe; Nettles, Hemp, Hops. Trees belonging to the Nettle Tribe. The Fig, the Banyan Tree, the Upas Tree, the Bread Fruit Tree, and the Cow Tree. The Mulberry. Mode of treating Silkworms.

18. The English Oak. American Oaks. Other kinds of Oak. The Cork Tree. The Beech. The sweet Chestnut. Hornbeam. Hop Hornbeam. Hazel. Characteristics of the Cupuliferæ . . . . . . 351

19. The Birch. Lines of Vegetation marked in ascending lofty Mountains. Birch Tents and Canoes. The Alder. The Elm. The Nettle Tree. The Walnut. The Hickory. The Willow Tribe, Napoleon's Willow, and Johnson's Willow. The Poplar. Uses of Trees belonging to the Willow Tribe. Plane Trees. Great Plane Tree of Buyukdere . . . . 377

20. The Mezereon. The Spurge Laurel. The Sweet Bay. The Camphor Tree. The Cinnamon. Pepper. 
Chapter

Beet, and Mangold Wurtzel. Rhubarb. Heaths. Page Arbutus Tree. Bilberries and Cranberries. Rhododendrons, Azaleas, and Kalmias. The Primrose Tribe. Convolvulus. Phloxes. Lobelias. Campanulas or Blue Bells.

21. Jesuit's Bark, or Quinquina. The Coffee Tree. Ipecacuanha. The Honeysuckle Tribe. Snowberry. The Jasmine. Elder Tree. Laurustinus and Guelder Rose. Viper's Bugloss. Forget-me-not. The Compositæ. The Nightshade Tribe ; Tobacco; the Potatoe, the Loveapple or Tomato, and the Egg Plant. The Mint Tribe. Verbenas. Snapdragon and Foxglove. The Olive Tribe, the Ash Tree, the Manna Ash, and the Periwinkle . . . . . 423

22. The Scotch Pine; the Spruce Fir; the Silver Fir, the Larch, the Cedar of Lebanon, and the Deodara. The Cypresses. The White and Red Cedars. The Arbor Vitæ. The Junipers. The Yew and the Salisburia. Distinguishing Marks of the Dicotyledonous Plants . . . . . . . . . 446

23. The Ginger Plant. The Indian Arrow Root. The Narcissus Tribe. American Aloe. Snowdrop, Snow Flake. Corn Flag, Iris. Pine Apple. Orchis Tribe. Date Palm. Cocoa Nut. Sago Palm. Cabbage Tree. The Lily Tribe, Tulips, Lilies, Onions, and Garlic. Crown Imperial, Squills, Star of Bethlehem, Hyacinths, Lily of the Valley, Asparagus, Butcher's Broom, New Zealand Flax, the Yucca, and the Aloe . . . . . . . . 466

24. The Grass Tribe, including Wheat, Rye, Barley, Oats, Indian Corn, Millet, Rice, the Sugar-cane, and the Bamboo. Aquatic Plants. Rushes, Duckweed, \&c. Mosses, Ferns, Lichens, Seaweed, and Fungi . . 


\section{PETER PARLEY'S}

\section{TALES ABOUT PLANTS.}

\section{CHAPTER I.}

PETER TELLS ABOUT THE DIFFERENT KINDS OF CLEMATIS: OR VIRGIN'S BOWER, AND TRAVELLER'S JOY. OF THE USE THE FRENCH BEGGARS MAKE OF THE LATTER. PETER ALSO TELLS OF THE DIFFERENT KINDS OF ANEMONE, WITH THE STORY OF M. BACHELIER; AND OF THE HEPATICA.

MY dear Boys and Girls, during the long winter nights, when the fierce winds and the deep snow prevented us from walking out to enjoy the blessings of Nature, we fell back upon another great virtue; we cultivated a good and neighbourly feeling; we met together round the winter fire-side of my little brown cottage; you, my little dears, to listen, and I to relate my various adventures in different parts of the world. You no doubt remember that nearly the whole of last winter was occupied by your hearing, 
and my relating "Tales about the Sun, Moon, and Stars," and about "Rome and Greece." Now that the spring is far advanced, summer is near, and the beauties of Nature are breaking forth, we cannot do better during your holidays than to cultivate an acquaintance with the works of nature. Let us then discourse profitably on the goodness of God as seen in the vegetable world, and speak of trees and plants, "from the cedar that is in Lebanon, unto the hyssop that springeth out of the wall." Well! well! I see you wish me to begin, so come with me into my garden, and I will tell you some of my tales about plants.

Though I have but a small house, I have a large garden, and I have many beautiful flowers in it, which delight the eyes of an old man like me to look at. I have a pleasant bower too at the end of my garden, where I sit and enjoy my flowers; and bless God for his mercy in having given me so many comforts in my old age, and such a happy home after all my adventures.

\section{The Crowfoot Tribe (Ranunculacea).}

Now look my children at that plant which hangs down so gracefully over my bower! See how its 
beautiful purple bell-like flowers project on their

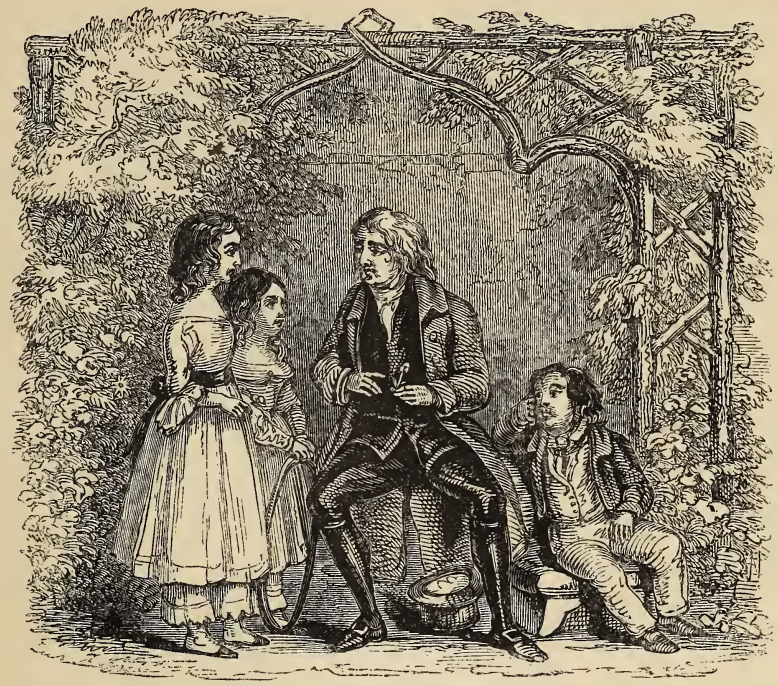

long footstalks from the mass of leaves, and how bright and transparent they look, with the sun shining behind them. That plant is called the Clematis Viticella, or Purple Virgin's Bower.

It does not grow wild in England, but it was brought to this country from Spain above two hundred years ago. This was in the time of Queen Elizabeth; and 
when she saw the plant, with its elegant drooping purple flowers, she said, " Let it be called Virgin's Bower; since it will make such a beautiful bower for young maidens to sit in."

There is another kind of Clematis also hang-

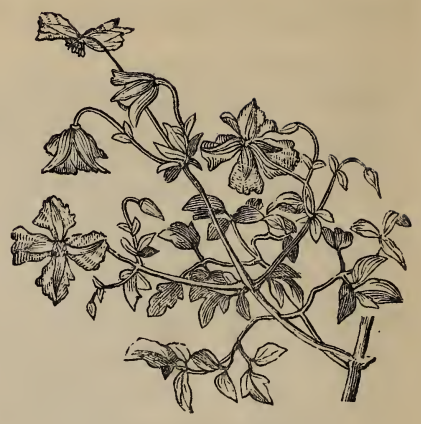

PURPLE VIRGIN'S BOWER. ing down over our

heads. Look at its large, star-like white flowers, how they shine through the dark green leaves. This plant comes from Japan; and like nearly all the plants that have been brought to England from that country it is very handsome. It is more tender than the purple Virgin's Bower; but it grows well in my sunny garden; and when the winter comes,

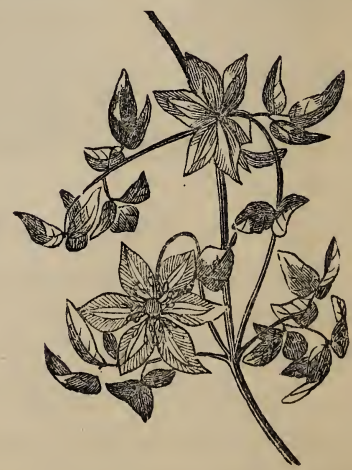

SHOWY-FLOWERED CLEMATIS. 
I cut down its long shoots, that it may spring up more vigorously next year. This kind is called Clematis florida, the Showy-flowered Virgin's Bower.

Besides these plants, and many others of the same kind which have been brought from foreign countries, there is a Clematis which grows wild in England, and which I will show you when we walk out together in the lanes. This kind is called the Clematis Vitalba, or the Traveller's Joy; and its English name has been given to it, because it grows over the hedges by the road sides, and makes them look gay and cheerful, for the travellers to look at, as they journey onwards.

The Traveller's Joy grows wild in France, as well as England, and in that country it is called the beggar's herb; because the beggars who wish to make good people pity them, and give them money, gather the leaves of this plant and bruise them, and then they scratch their arms and legs, and bind the bruised leaves of the Traveller's Joy on the place. These leaves are what is called acrid, and they would blister your lips if you were to chew them: they are also poisonous, and would make any person die in dreadful pain who was to eat them. When they are tied upon the slight scratches on the beggars' arms and legs, they make them become bad wounds; and 
then charitable people who see them, and who do not know how wicked the beggars have been, are sorry for them, and give them money. When the stem of the Traveller's Joy becomes old and withered it loses its acridity; and the shepherds in France and Germany cut the old wood stems which are quite hollow, into short pieces, and lighting them at one end, they smoke them like pipes.

The flowers of the Traveller's Joy are not so handsome as those of either of the other kinds of Virgin's Bower that I have told you about, but they smell like sweet almonds; and their seeds are beautiful. If you will come with me into the lanes in September or October, you will see the hedges covered with what look like tufts of Marabout feathers, waving gracefully in the wind. These are the long, light silky tails of the seeds of the Traveller's Joy; and their All-merciful Creator has provided them with these appendages; because as the plants grow in hedges, the seeds might fall into the middle of the hedges among the branches, and never reach the ground, if they had not been provided with this kind of wing, which the wind acts upon, and blows them away from the top of the hedge to the ground.

All these kinds of Clematis are called climbing 
plants; because they have not thick, strong trunks like trees: and when they grow, their long slender stems would lie on the ground, if they had not something to climb up to support themselves. They will climb twenty feet high or more when they are trained against a bower; and when they are not near a house, or any thing they can be trained against, they will hang over a hedge, or run up the trunk of a tree, twisting their slender tendrils round the branches, and hanging their light festoons of flowers, or feathery seeds from bough to bough.

It is because they climb up trees or trellis work by means of their tendrils like the vine, that they are called Clematis; for Klema is the Greek word for the tendril of a vine.

There are many other kinds of Clematis besides these, but it will be time enough for you to know them when you are old enough to study botany; and I will now only tell you about one more, which you would hardly know to be a Clematis, because it does not climb; but if you will look at the flower you will see it is like one of those which hang down over our heads. It is called Clematis integrifolia, or the Hungarian climber; but the last you will see is a very bad name, because though it comes from Hungary, it is not a climber, and so I think it would be 
better to call it the entire-leaved Clematis, for that is the meaning of the Latin name.

Did you ever see the Wood Anemone? It is a beautiful little flower, growing among the long grass in thick woods, and on the grassy banks of hedges. It is one of the flowers of early spring; and even in March when the sun shines brightly, the little wood anemones may be seen, raising their heads above the grass, and opening their snow white flowers to the sun, as widely as possible, as though to get as much as possible of warmth and light. When the weather is wet and gloomy, the little anemones close their petals, and hang their drooping heads as if they were mourning for the loss of that sun, in which they had so much delighted. Botanists call this flower Anemone nemorosa.

When the wood anemone is brought into gardens, and planted in rich soil, its flowers become double; but I do not think these cultivated flowers half so beautiful as the little wild ones. There are many other kinds of anemone, which grow wild in England; some have bright yellow flowers, some are bluish, and some have large white flowers. They are all very beautiful, and they all blossom in early spring.

Besides these, there is the Purple Anemone, or 
pasque flower, which is also a native of England, where it grows on open heaths, and in exposed places. It is called pasque flower, because it flowers about Easter, which the French call Pâques; and its botanical name is Anemone Pulsatilla. This flower has light, feathery, silky seeds, like those of the traveller's joy, which produce a beautiful shining appearance when they are waved to and fro in the wind; and it is because the plant looks most beautiful when its seeds are blown about by the wind, that the Greeks called it anemone, which, in their language, signifies wind flower.

Have you ever been in a seed shop and seen boxes filled with dark brown curiously shaped roots, that look something like bundles of little shrivelled black figs. These uglylooking roots are those of the Garden Anemone; and if you buy some, and plant them in your garden, they will produce you a beautiful flower something like this. There are two sorts of gar-

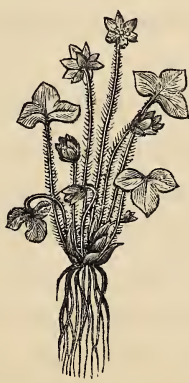

PINK HEPATICA.

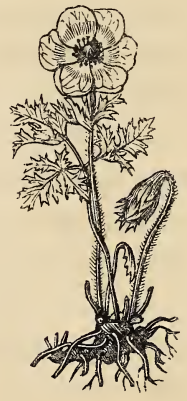

L

GARDEN ANEMONE. 
den Anemone; and of the sort of which I have just shown you a flower (which is called the Poppy Anemone) there are more than two hundred varieties! You may well be surprised; but you will be still more so when you hear that of the other kind, which is called the star anemone, there are as many varieties. And all these are so distinct, that people who are accustomed to grow them know them at first sight, and can call them by their different names. I do not know a tenth part of their names; but if I did, and could tell them to you, you would not be able to remember them without seeing the flowers, so it would not be of much use. But I may tell you that I have seen garden anemones bright orange, bright scarlet, and bright purple; and in Holland, what they call Dutch anemones, broader than my hand. These last are very fine flowers, and are now often to be met with in England.

I am now going to tell you a curious story about the way in which it is said that these garden anemones were first made common in Europe, for they came originally from Asia. There was a gentleman in Paris, whose name was M. Bachelier, who procured some of these beautiful flowers from the East Indies; but he was of a very selfish disposition, and though he was very proud of having these fine 
flowers in his garden, he would not let any one have any of them but himself. He kept them thus ten years, till at length a counsellor of the parliament, who was very fond of flowers, having tried several times to buy some of them, was determined to try if he could not punish M. Bachelier for his selfishness. The counsellor accordingly went to see M. Bachelier at his country house, and when they were walking in the garden, and came near the anemones, which were in seed, the counsellor let fall his gown over that part of them that was near the walk, and as he swept it along, the seeds, which are rough (though not so feathery as those of the pasque flower), stuck to it. The counsellor then gathered up his gown, and carried off the seeds without M. Bachelier knowing any thing about it.

I do not mean to say the counsellor was right, though in a year or two he gave the seeds away freely to any body that asked for them, and it was by his means that this beautiful flower became so common as it now is; but still he ought not to have taken what did not belong to him; yet I am glad that selfish man was punished. Nobody can be good that is selfish; and when we give other people a share of what we have, we enjoy what we keep much 
more than any selfish person can do who has kept all he had to himself; and we have besides the pleasure of seeing the people we have given something to, enjoying themselves, and the satisfaction of knowing that we have made them happy.

I am sorry to tell you that all these beautiful anemones are poisonous: but the wild sorts are the worst; for plants are like children, their bad qualities are softened, and often entirely removed by cultivation. The bruised leaves of all the wild kinds will raise blisters on the skin, and if eaten, they will cause a heat and soreness in the throat and tongue, and violent sickness : a large quantity would occasion death. Even that beautiful little wood anemone which I first told you about would poison cattle if they were to eat it; but that Almighty Being who has created both it and them, has placed it in woods where cattle rarely come, and not in fields, where they could hardly fail to eat it. Thus wisely has every thing been arranged, and thus do we always find in nature every plant fitted to its place.

Early in the month of March, and often before the last snow has melted entirely away from the ground, the pretty little Hepatica opens its blue, white, or pink blossoms to the sun; and nothing can be more 
beautiful than to see patches of it forming complete masses of flowers, gleaming amid the desolation around them. The flowers of this plant are always welcome, because they seem to assure us that winter has given place to spring, and spring is always a joyous season. Even my old breast warms when I hear the birds singing, and see the first young delicate leaves beginning to unfold; it seems to bring back the feelings of my youth, and my garden never looks so beautiful in my eyes, as when it is blooming with the hepaticas, and other flowers of spring.

In Canada, the red hepatica forms a rich carpet through the woods; for this little plant is found wild in North America as well as in Europe, and it is a favourite every where. In English gardens, the flowers are generally double; and the pink and white varieties look like little double roses. The blue is also very pretty, and might be compared to a little double blue rose, only we have no blue roses. However, all the three kinds are so pretty that I don't know which I like best, and if you will come and see me early next spring, you will find all three blooming in my garden.

The flower of the Hepatica remains a long time in the bud-that is to say, the buds that form this year 
will not expand till next spring; and yet the little flower shut up in this bud is as fully formed, and of as fine a colour, as if it were just going to open. This is not the case with most flowers. If you take an unripe rose-bud, and cut it open, you will find the petals of a pale whitish, or rather pale greenish pink, and not at all of the beautiful deep rose colour that they will have when the flower is just ready to expand. Do you know what I mean by the word petals? The petals are the flower leaves. Here is a bud of the pink Hepatica, which I have just gathered. You see the outside of the bud is of a brownish green : this is the calyx or covering. Now this calyx consists of three leaves, as you will see when I open them with a pin. There! now these calyx leaves are called sepals; and these bright pink ones, which form what is called the corolla of the flower, are the petals. Thus you see the flower leaves are called petals, and the calyx leaves sepals, to distinguish them from the common green leaves of the plant, which are called simply leaves.

The Hepatica is called by the country people Noble Liverwort. I am sure I don't know why they call it noble; for though it is as pretty modest looking a flower as any I am acquainted with, I certainly 
cannot see anything noble about it. Liverwort is also not a very appropriate name, for it might lead people to suppose that it was good to be taken medicinally to cure diseases of the liver; while the fact is, that it is poisonous, like all the plants we have yet been talking of. You will never guess why it is called Liverwort. It is because its leaves are three lobed, and something in the shape of a liver; but so little, that I think no one would ever guess it without being told.

\section{QUESTIONS.}

1. Why is Clematis Vitalba called the Traveller's Joy? 2. What are the qualities of all the kinds of Clematis? 3. What is the derivation of the word Clematis? 4. Why are some plants called climbers? 5. Why are Anemones called by that name, and what is its meaning? 6. When does the Hepatica come into flower? 7. Why is it called Liverwort?

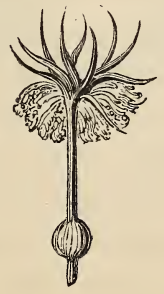




\section{CHAP. II.}

PETER TELLS ABOUT THE MEADOW RUE AND MARSH MARIGOLD. MAY GAMES. THE RANUNCULUS, FICARIA, GLOBE FLOWER, WINTER ACONITE, CHRISTMAS ROSE, FLOS ADONIS, AND PEONY. HISTORY OF THE CHINESE PEONY. BOTANICAL COLLECTORS. LOVE IN A MIST, COLUMBINE, MONKSHOOD, AND LARKSPUR.

The Crowfoot Tribe, or Ranunculacee. Continued.

So! here you come with flowers in your hands, and looking as gay and blooming yourselves as any flowers you can bring. I suppose you want to know the names of these. Well, well, I'll tell you, and also all I know about them; but first I'll tell you where you gathered them. It was by the side of the little brook that runs through the field behind my garden. Ah! ah! I see you laugh-I knew I was right.

One of these is not a very pretty flower; it is called the common meadow rue (Thalictrum flavum). There is another kind which grows in Scotland, which is much prettier; but the prettiest of all the English kinds is that which grows on the sea coast, and is called Thalictrum minus. The common sort is used 
by country people, who cannot afford to employ doctors for trifling complaints, to raise blisters behind their ears when they have the toothache.

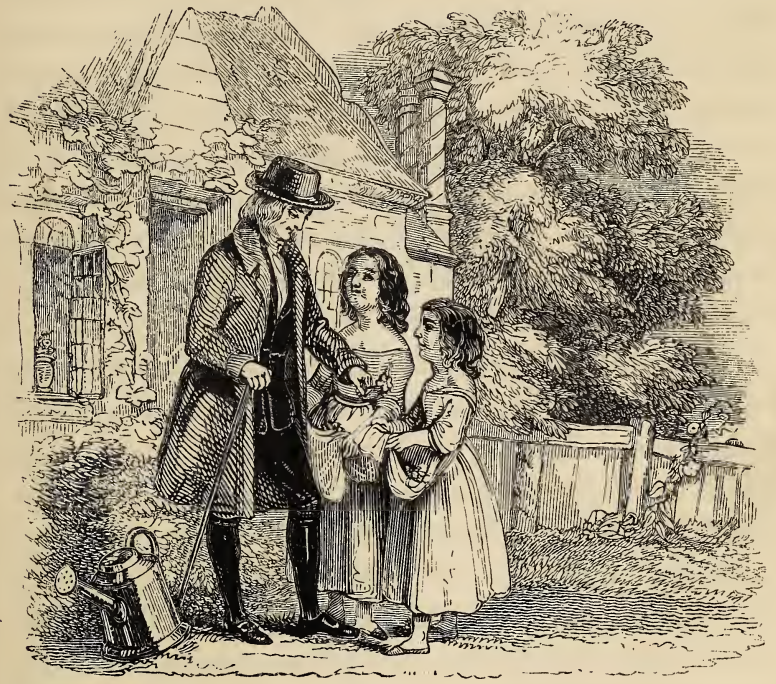

This is a much more beautiful flower; look what a fine bright yellow it is; it is like a great buttercup. It is called Caltha palustris, or the Marsh Marygold. The word Caltha signifies a cup or bowl, and you 
may see the shape of the flower is quite like that of a cup or basin. Palustris signifies a marsh, or ground near water. Thus you see these hard names, as they seem to be, are easy to be remembered when we know their meaning. The Italians call this flower the spouse of the sun; because, I suppose, its great, broad, bright yellow head, when it is fully expanded in their warm climate, puts them in mind of that luminary. In England it is always cup-shaped like this. In some parts of England it is called waterblob, but this appears to me a very ugly name. What do you think of it?

The marsh marygold is a favourite flower with the country people; and in some parts of England they gather these flowers on May-day, and strew them before their doors, or twine them into garlands. You must have seen Jack-in-the-Green dance on Mayday with the chimney-sweepers. Now, in some parts of Warwickshire, and other counties of England, they do not have the chimney-sweepers to dance on Mayday, but the milkmaids; and one of the milkmaids carries a long pole, ornamented with ribbons and garlands of flowers. In other places there is what is called a May-pole fixed on the village green, and the young men and maids hang it with garlands of 
flowers, and dance round it; choosing one to lead their dances, who is called Queen of the May.

These May games are very old. They were even common before the Britons knew the true God, and when they believed in the gods and goddesses of the Romans, who were heathens. The Romans used to worship a goddess of flowers, whom they called Flora; and these dances were originally in her honour. Very few people who dance in the May games have any idea of their origin; but it is curious to trace these things, and to see how many things we do merely because we see others doing them. Well, well, I am forgetting your flowers; now let me look at the others you have gathered, that I may tell you about them.

This is the common buttercup, or crowfoot of the meadows. It is a very common little flower, but it is a very important one to botanists, for it gives its name to the natural order Ranunculaceæ. You look at me, as if to ask what that means; and I will tell you as simply as I can. A great while ago people who were fond of plants found it difficult to remember them; and so, to help their memory, they put those that were a good deal alike together in what they called orders or classes. There are a great 
many ways of doing this, that you will know more about when you get older; but in what is called the Natural System, and which modern botanists consider the best, those plants are put together that are like each other in their qualities, as well as in the construction of their flowers and seeds.

Do you understand this? If you do not, I must try to make it a little plainer. All the plants I have been telling you about belong to the order Ranunculaceæ; because they are all more or less like this little Ranunculus in their seeds, and in the way in which that little bundle of yellow threads, which are called stamens, grows out of the centre of the flower. Look at this little flower, and you will see in the centre of its five bright shining yellow petals a little heap of green grains; these are called the carpels or seed vessels, because every one of them contains a seed; and it is in having all those little yellow threads, which, as I have just told you, are called stamens, growing from beneath these carpels, that all the plants agree which belong to the order Ranunculaceæ. Look! I will pull off all the petals of the flower, that you may see how the stamens grow from beneath the heap of little green grains that are in the centre. Another point in which all the plants be- 
longing to this order agree, is in having the carpels growing close together, but not growing together. Do you know what I mean? It is that though these carpels grow as near together as possible, they are yet quite distinct, and are not joined together so as to form one head.

All the plants belonging to this order also resemble this little buttercup in their properties. They are all more or less poisonous, and the leaves of all of them would make your lips and tongue very sore, and perhaps raise blisters, if you were to chew them. They would also make you very sick and uncomfortable if you were to swallow them, and some of them would kill you.

The buttercup you have brought me, and which you found near the little brook, is called the Creeping Crowfoot (Ranunculus repens); but the commonest kind, which spreads all over the meadows in summer, and which makes them look quite yellow, is the Upright Crowfoot (Ranunculus acris). Some people fancy, because these buttercups look so yellow, that the cows eat them, and that they make the butter look so rich, and of such a fine colour in summer. But the cows do not eat them; and when cows have been a long time in a field where there were many 
buttercups, the dry stalks of these flowers will be found to have been left standing by the cows, who have eaten all the grass around them. Thus wonderfully does the instinct implanted in animals by their Creator teach them what they may eat with safety, and what they ought to avoid.

When we go into my garden, I will show you some of these buttercups, which have been grown in rich soil, and have been thus made to become double. They look like little yellow roses; and they are called Yellow Batchelor's Buttons. You look surprised, and I dare say thought them quite different flowers from the common buttercup; but they are nothing but the double variety of the upright meadow crowfoot. The White Batchelor's Buttons, or Fair Maid of France, is the double variety of another kind of crowfoot (Ranunculus aconitifolius), which grows wild among the Alps.

There are many other kinds of Ranunculus, but it would take me too long to describe them all; and I must tell you about the beautiful double Persian Ranunculuses (Ranunculus Asiaticus). These are those very splendid double flowers, which you may have seen nosegays of in Covent Garden market. When people want to grow this kind of ranunculus in their 
gardens they buy the roots, and plant them. The roots are kept by the seedsmen in little boxes like those of the anemone, and each of them looks like a bundle of very little dark-brown carrots.

Here is a root of the Ranunculus, and another of the Anemone, that you may see the difference between them.

The flowers of the Persian Ra-

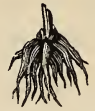

RANUNCULUS

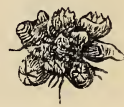

ANF.MONE ROOT. nunculus are of a great many different colours; some are dark purple, some are blackish, and some scarlet; some are orange, and some yellow ; some are spotted, and others quite white, or with each petal bordered with a line of dark red or purple. They are all very handsome; and beds of them make a splendid appearance in spring. The first flowers of this kind grown in England were brought here from Persia in the time of Queen Elizabeth.

But I have not told you the meaning of the word Ranunculus. It is from Rana, a frog, so whenever you hear a frog croaking, you will think of the botanical name of the buttercup.

This is the Lesser Celandine, or Pilewort (Ficaria Ranunculoides), which grows wild in woods, and which is well known by most little folks from the 
pretty verses that were written about it by Wordsworth. The flowers are of a bright shining yellow, and the leaves of a shining green; but the most curious thing about the plant is that when the flowers fade, littlenew roots begin to form above the old roots; and as
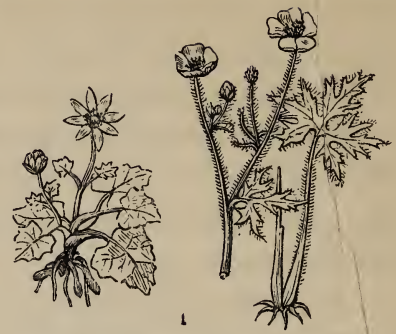

LESSER CELANDINE. BUTTERCUP. these little new roots are whitish, and very small and fleshy, they look very much like grains of wheat. These new roots growing above the old ones do not go deeply into the ground, and when a heavy shower of rain comes it lays them quite bare; and formerly when the country people saw this they used to fancy it had been raining wheat!

Now, look round my garden, and see if you cannot find a flower which is something like the Crowfoot. You are quite right in bringing me the Globe flower (Trollius Europæus), for that is the flower I meant. This plant grows wild in the north of England and Scotland ; but near London, it must be cultivated in the gardens. Do you know what I mean when I say cultivated? Any plant the seeds of which are 
sown, or the roots of which are planted by man, is said to be cultivated; while those that spring up naturally, without any care, are said to grow wild. When flowers are cultivated, by taking up their roots in the fields or meadows, where they grow wild, and planting them in a garden, the soil of which is rich, they grow much larger and finer than they did in their native place; and, in a few years, they often become double.

This is not the case, however, with the Globe flower, for it remains very nearly the same in the garden as it was in its wild state. And so do those two beautiful flowers of early spring, the Christmas Rose and the Winter Aconite. Have you ever seen, peeping up, even amidst the snow, a large cup-shaped white flower beautifully tinged with pink. This is the Christmas Rose (Helleborus niger), and the Winter Aconite (Eranthis hyemalis,) is not long in following it. As soon as I feel the first warm breath of spring, I go into my garden and look round for this little yellow flower; and I generally find it surrounded by a circle of leaves, and seeming to repose upon them.

I am now going to show you a bright scarlet flower, that I think you will like to know the name of. It is 
called the Flos Adonis; because the ancient Greeks and Romans, who you may have heard believed strange fables, fancied that because it was the colour of blood, it sprang from the blood of Adonis. This scarlet flowered Adonis (Adonis autumnalis) is called an annual, because it dies every year; and must be raised again every year from seed. I let my seeds ripen on the plant and sow themselves, and in consequence, my plants flower early; but if you buy the seeds and sow them in March or April, your flowers will not appear till autumn.

There is another kind of Adonis (Adonis vernalis) which has yellow flowers, and which flowers in spring; but this kind is called a perennial, because it does not die every year, and it is increased by dividing the root, instead of sowing the seed. If you were to sow the seed, young plants would come up, but they would not produce flowers till they were two years old. All the plants I have told you about before the Adonis, are perennials, except the climbing sorts of Clematis, and they are called shrubs, because their stems are woody.

\section{THE PEONY.}

I am now going to show you one of the most splen- 
did flowers in my garden. Can you guess which it is? Yes, you are right, it is the double Pæony (Pæonia officinalis). Of what a rich crimson are its petals! It is a native of Switzerland, and grows wild among the Alps, on which account, the Italians and Spaniards call it the Mountain Rose. It has, however, been long an ornament of British gardens; for it was introduced in the time of Henry VIII (1548), nearly three hundred years ago. There are many other kinds of Pronies, white, pale pink, and deep rose, and one of the kinds with white petals is sweet-scented. Another kind is a native of Britain, though it is very seldom found wild now; and the seed vessels of this kind (Pæonia corallina) are almost as handsome as the flower.

I am now going to tell you about the Chinese tree Pæony (Pæonia Moutan). Many many years ago, when the Dutch East India Company sent an embassy to China (1656); the persons belonging to this embassy went to Pekin; and they were there allowed to visit the gardens of the emperor. As soon as they came home they spoke continually of these beautiful gardens, which they seem to have admired more than any thing else that they saw; and in which they said there was a Pæony called the Moutan, with 
a trunk like a tree, twelve feet high, and covered with great double flowers like roses, as large as a child's head. People laughed at this story, and thought that it was only one of those travellers' wonders, which nobody believes.

Above a hundred years after the book was published, which gave an account of the travels of these Dutchmen, an English gentleman, Sir Joseph Banks, read it; and he thought to himself that he should like to see this "king of flowers," as the Chinese called the great Pæony. So as he was very rich, he sent some botanical collectors to China, to buy a plant of it from the Chinese, and bring it home. They did so after a great deal of trouble, and it is now tolerably common in gentlemen's gardens. In general, however, it is only three feet or four feet high ; but in some places it has grown as high, and produced as large flowers, as it does in China. When these plants were first introduced into France, one of them is said to have been sold for a hundred guineas.

I told you just now that Sir Joseph Banks sent botanical collectors to China to bring home this fine plant. Now, do you know what is meant by a botanical collector? If you do not, I will tell you. A 
botanical collector is a man who has studied botany thoroughly, and knows nearly all the plants that are natives of his own country, or that have been introduced into it from other places; and who goes into foreign countries to try to find new plants. Now, as in all civilized countries, where travellers go frequently, all the plants are known, it is clear that the collector who wishes to find new plants, must go into uncivilized countries, where few travellers have been before him. Thus the poor collector is obliged to go through the greatest difficulties and dangers. Sometimes he is obliged to wander for several days together without finding a bed to lie on; and at others he can scarcely get any thing to eat. He is also liable to be attacked and killed by savages, or by wild beasts. When we see the beautiful flowers that are growing in our gardens, and which have been brought there from so many different parts of the world, we little think of the toils and dangers that have been gone through to obtain them. But I shall tell you more about botanical collectors by and by.

I must now show you some other flowers belonging to the crowfoot tribe. Here is the little Love-in-amist peeping through its mass of leaves (Nigella 
damascena). This genus is interesting to botanists, because it differs from all the other plants of the Crowfoot tribe, in having its carpels growing together so as to form one head, instead of being distinct. The seeds of another species of the genus (both are natives of France) were formerly used instead of pepper. Then here is the Columbine (Aquilegia vulgaris), and the Monkshood (Aconitum Napellus). But I must tell you a story about this last.

I have already told you that all the plants belonging to this order are poisonous. Love-in-a-mist is perhaps the least so, but even it would kill you if you were to take much of it; and this is the case with all the rest. Of all these plants, however, Monkshood is the most deadly poison. Many years ago a friend of mine knew a man who had it growing in his garden. This man, who was poor, was very fond of celery, but he did not often eat it, because he could not afford to buy it. One day he was digging in his garden, and he saw the root of the Monkshood which looked nice and white like celery; and he came in to his wife and family with it, crying "We will have a treat to-day!"

My friend happened to call upon the family just as they were going to eat this poisonous plant, and 
as he knew what it was, he told them not to touch it; but the man did not mind what was said to him, and he ate it, and gave some to his wife and children. One little boy would not swallow it, because he said, it made his mouth smart; and he escaped with being dreadfully sick for many days, but all the rest died.

I could tell you many other cases, but this will be enough to show you the dangerous nature of the plant. Many people have died from using the root instead of horse radish ; and the ancient Greeks and Romans dipped their arrows in its juice when they went in pursuit of wild beasts. It is a great pity the Monkshood is so poisonous, for it is both pretty and curious, The upper part of the flower is something like a monk's hood, and when you pinch it, two long stamens start out from under it, the ends of which look like eyes. You may gather one of the long spikes of flowers to try to make the stamens start out as I told you they would; but first let me look at your hands to see if you have any scratches or cuts on them, as it would be very dangerous to let the juice of this plant touch any sore place.

The Larkspur is a beautiful genus of plants. Do you know what I mean by the word genus? I told you before that an order consisted of all the plants 
that were a good deal like each other in some particular respects; but a genus consists of plants which are very much like each other indeed. For example, all the different kinds of Larkspur form one genus: and so did all the different kinds of Anemone; and all the different kinds of Clematis. And each of these different kinds is called a species. Thus there are many species in a genus; and many genera in an order. So now let me tell you about the Genus Delphinium; that is, in English, the Larkspurs.

They are very curious plants, as well as very beautiful ones. If you look at some of them, you may almost fancy that you see a little bee nestling in the centre of the flower; and others look like clusters of roses; while others have bright deep dark blue flowers, which shine in the sun as if they were made of burnt silver.

The first of these kinds, the common Bee Larkspur (Delphinium elatum), grows sometimes six feet high. It is a native of Siberia, but has been cultivated in British gardens for nearly three hundred years. The rolled-up petals in the centre of the flower are so like a bee, that a story is told of a poor boy who cried till he went into fits, because some silly person threw a handful of these flowers at him, and he 
thought that they were real bees, and would sting him.

It is the Rocket Larkspur that looks so like a string of fairy roses. This plant (Delphinium Ajacis) grows in its wild state in little valleys among the Alps in Switzerland, and it has been cultivated in British gardens still longer than the bee larkspur. There is one thing very curious in these flowers. This is the spur-like shape which is taken by the back of the single flowers. Now, when the flowers become double they lose this spur.

The Siberian Larkspur (Delphinium grandiflorum) has its flowers of a rich metallic hue. These flowers are blue, and when the light glances on them, they look as if they were made of burnt silver, or burnt steel. There are many other species belonging to the genus, but these are the most remarkable.

All the plants I have told you about, and many others, belong to the natural order Ranunculaceæ, or Crowfoot tribe; that is to say they all resemble in many important particulars the wild ranunculus, or common crowfoot. They are all more or less poisonous; and they all, besides resembling each other in the particulars I told you about when I was describing the common buttercup, exude, when their 
34

stems are cut or broken, a watery juice, which if it were to touch any scratch or other sore place would probably make it fester.

\section{QUESTIONS.}

1. Why is the common buttercup an important flower to botanists?

2. What is a botanical collector? sonous of all the Crowfoot tribe? word genus?

5. What is the 6. What are the principal properties of the Ranunculaceæ ?

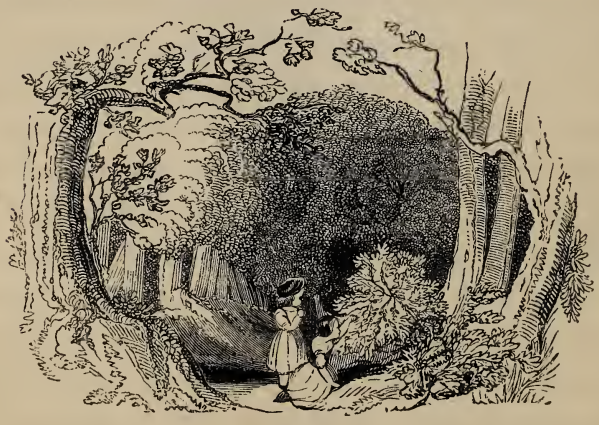




\section{CHAP. III.}

THE STORY OF DOUGLAS, THE BOTANICAL COLLECTOR.

Mr. David Douglas was a Scotchman who was employed by the Horticultural Society of London to collect seeds for them in different parts of North America. This society consists of a number of ladies and gentlemen, who pay a sum of money every year to keep up a fine garden, where all kinds of trees and shrubs and vegetables and flowers are grown; and to send out collectors to other countries to find new plants. The parts of North America that Douglas was sent to, were not the large towns, but where the Indians live, whom I have already told you of in my tales about America.

Douglas, when he was a very little boy, was so fond of birds, that he collected all the different kinds he could get, especially hawks and owls. As he was poor, he had, however, great difficulty in getting food for these creatures; and for the sake of feeding some young owls, a nest of which he had taken, he used to contrive ways of catching mice and small 
birds. Not being very clever at this employment, he used frequently to spend the penny that was given him every day to buy his own lunch, in purchasing bullock's liver for his young birds; though he had to walk six miles to school and back again, which I am sure was quite enough to make him hungry.

When Douglas grew older, he used to sit and read all the time he could spare; and his favourite books were Sindbad the Sailor, and Robinson Crusoe. He was soon employed as a gardener; and as he was now obliged to work hard all day, he used to learn passages of his favourite books, and of others about plants, by heart at night, that he might say them over to himself, and think of them while he was digging in the garden during the day. When the summer came, he used to go out at all his leisure hours into the neighbouring fields and lanes to collect all the plants he could find; and his master, seeing how fond he was of this amusement, gave him a little garden of his own to plant them in.

Industry, a strict performance of one's duty, and an ardent desire to acquire knowledge, are qualities that never fail to meet with their reward; after working for some years in the gardens of Scone palace near Perth, Douglas was chosen from among 
a number of other young men to go into the Highlands of Scotland to collect plants. He did this so well, that he was afterwards sent, when only twentyfour years of age, to North America; which was thought a great honour, as only the cleverest persons were chosen.

When Douglas was a young man working in the gardens in Scotland, he had a little dog that he was very fond of; and this little dog he took with him in all his travels. Before he reached America he stayed a short time at Juan Fernandez; the island on which Alexander Selkirk was wrecked, whose adventures gave rise to the story of Robinson Crusoe. On this island, he found an Englishman whose name was Clarke, and who had lived there five years. When this man saw strangers coming, he abandoned his hut, and fled into the woods; but when he heard the strangers speak English, he sprang forward, and welcomed them with the greatest joy.

This poor man had no clothes but what he had made himself. "His little hut was built of stones and turf, and thatched with straw of the wild oat." In one corner lay a bundle of straw and his blanket; and this for a bed, and a log of wood to sit upon, were all his furniture. He had no vessel for cooking 
in but an iron pot, and this having lost its bottom, he supplied its place with a piece of wood. You may easily suppose such a vessel as this could not be set on the fire, as that would have burned out the wooden bottom; so that poor Clarke could only boil any thing by making a hole in the ground in which he placed his vessel, and then surrounding the upper part with fire on every side. When we read these things, and hear of the troubles which so many of our fellow creatures are obliged to submit to, how thankful we ought to feel to our Heavenly Father, for having given us a roof to shelter us, a comfortable bed to sleep in every night, and plenty of food to eat, dressed in any way that we may fancy. Poor Clarke longed to taste roast beef, and tried very often to contrive a means of roasting meat; but the flesh of the wild cattle that he lived on was very different from English beef. It was tough, dry, and full of sinews; and there were no butchers to skin it, and cut it up properly. So poor Clarke was obliged to do without roast beef, and as he could not get that, he was content with what he had; and thanked God that he was placed in a situation where he had plenty of food however coarse or ill-cooked it might be. 
From Juan Fernandez, Douglas went to some other islands, called the Gallipagos, which are mountainous and volcanic. In one of these islands the birds were so tame that they came and sat on Douglas's shoulders, and even perched upon his gun, not knowing how dangerous an instrument it was in the hands of a man. So confiding are all living creatures in mankind, till they are taught caution by the cruelty they meet with.

At last Douglas arrived at Upper California, on the north-western coast of America, where he was to begin his labours. As there were scarcely any roads in that country he embarked in a boat on the river Columbia, and thus proceeded into the interior of the country. He was delighted with the wild and romantic scenery; high mountains rose on each side of the river, clothed with enormous trees. Douglas soon began to examine these woods, in search of plants ; but unfortunately, he had five Indians with him to manage his boat, who belonged to a tribe which was at war with another tribe inhabiting a village, near which he had ventured. When he drew near the Indian village, and the people in it saw the other Indians, they uttered a loud shout, and sent for their warriors; but one of the chiefs in the village, 
said he would protect the strangers, and asked them to stay in his house for the night. The next morning about three hundred warriors came clad in their war garments; and they danced their war dance, and sang several death songs, so that Douglas thought that he and his party would soon be murdered, but the good chief protected them and pacified the Indian warriors, who at last went away.

After this, Douglas gathered a number of beautiful flowers, which he dried between pieces of paper, to send home; and marked the places where they grew, that when he returned at the proper season he might know where to find them when they were in seed. While he was thus employed, he was obliged to sleep in the woods, only rolled up in his blanket, and with a large tree over his head. Sometimes he could get nothing to eat but the seeds of a large firtree; but one day he killed a young eagle, which he cooked in the Indian way, by making a hole in the ground, and lining it with flat stones; and then putting in the bird, and making a fire on those stones, which covered the top.

In this way he travelled on; sometimes catching fish in the rivers for food; and, when he had nothing to eat, smoking some tobacco which he had brought 
with him, to take away his hunger. One day, when he was doing this, one of his Indians ran after the smoke he puffed away, to try to catch, and swallow it ; crying, " Oh, master, master! Why do you throw away that good smoke! See, I take it into my body !" After this, he went through many troubles, but at last happily returned to England. After staying a short time in London, and seeing that all the seeds and specimens he had brought had arrived safely, he went back to America to collect more. When he went back to the same country where he had been before, the Indians were quite glad to see him. "Oh! said they, "Here is the Man of Grass come back again,"-for they called him the Man of Grass because he was always searching among the tall grass for new plants.

One day the Indians saw him mixing some powders to make a kind of soda water, and when they saw it bubbling up, they thought it was boiling, and called to him to stop when they saw him going to drink it; and at another time, they saw him use a burning glass to light his pipe, when they cried, " $\mathrm{Oh}$ ! oh! our Grass Man should be called the Man of fire now ; for he drinks boiling water, and brings down the sun to light his tobacco." 
When Douglas went farther into the country, he found the same difficulties as before. His best food was dry buffalo meat, which was as hard and tough as leather; and sometimes he had nothing at all to eat but a kind of moss, which he boiled till it became a jelly, in one of the pits lined with stones, which I have already described to you.

It would take me too long to tell you all his adventures; but I must relate one about some rats. He was sleeping one night in an Indian camp, with his faithful dog, as usual, lying by his side, when he was awakened by the barking of his dog, and opening his eyes, he saw himself surrounded by a herd of large rats. Some of these creatures were eating his seeds, and dried plants, pushing their noses in between the leaves of the paper he had put them in; and one very large rat was dragging away a box containing his soap, brush, and razor for shaving; while another, still bigger, had seized hold of his inkstand. Douglas was very angry, but the rats did not seem to mind either him or his dog; till at last he laid hold of his loaded gun, and fired at the rat which was taking away his inkstand. This killed the largest rat, and the others immediately ran away. Douglas afterwards measured the one he had killed, and found its 
body and tail were a foot and a half long, and its whiskers three inches long.

I am now going to tell you how poor Douglas died. After he had collected all the plants he could in the western part of North America, he went to the Sandwich Islands. Here he found many very curious things; and one day when he was wandering among the mountains, his guide showed the pits which the natives contrive to catch wild bulls in. These are deep holes sunk in the ground, and then covered with sticks and pieces of turf. When the wild cattle are frightened by noises which the natives make on purpose, they come galloping down the mountains, and treading upon the covering to these pits, which looks like the rest of the grass, the sticks give way, and they fall in.

Douglas thought this very curious, and he said to his guide that he should like to see one of the wild bulls in a pit; but there were none there at that time. That night he slept at the house of one of the missionaries who lived at a place called Hido, in one of the Sandwich islands ; and the next morning he took for a guide, an Englishman who was called Ned, to show him part of the road. Ned could not go far with him, as he had business to attend to, and so, 
after showing him the road, and telling him to take care of the bullock traps, he went home ; and Douglas went on, accompanied by only his faithful dog. Douglas had not travelled far, when he heard a dreadful roaring and noise in a pit that he had just passed; and feeling sure that a wild bull had tumbled in, he was very curious to see it. So he laid his bundle on the ground, and telling his dog to take care of it, he went back to look into the pit.

When Douglas reached the pit, there he saw the wild bull tearing up the bottom with his feet, and tossing his head against the sides, quite mad with rage to find himself entrapped. Douglas thought this very curious, and approaching too near to look at the creature more closely, his foot slipped, and he fell in himself. You may easily imagine what a dreadful situation he was in; the wild bull butted him with its horns, and then trampled on him till he was quite dead.

And where was the poor little dog all this time? When he saw his master fall, and heard his cries, mixed with the roaring of the wild bull, he was frightened; but still he did not dare to leave the bundle his master had committed to his care; and there he lay trembling, till he heard the footsteps of 
Ned the guide, who happened to be passing that way, but who thought Douglas must by that time be many miles on his journey. When the dog heard footsteps he barked with all his might, though still without leaving his bundle; and he barked so long and so loud, that at last Ned turned to see what was the matter; and when he saw the little dog lying on the bundle without his master, he knew that something extraordinary must have taken place.

I do not know what it was that made Ned turn back to look into the pit, for the bull was then quiet; but he did look into it, and there he saw poor Douglas lying stretched out quite dead, and the wild bull standing over him, and looking at him, as though ready to but him again if he should stir. As soon as Ned saw this, he ran as fast as he could to his own house, which was not very far off, for a gun, and when he came back he shot at the wild bull and killed it. As soon as the bull was dead, Ned went and fetched some of the natives to help him to get poor Douglas's body out of the pit ; which they did, and placed it on a bullock's skin, that they might carry it away.

Before the wild bull was quite dead, Ned went to the place where the bundle lay, to pick it up, and 
take it with him to his house; but the dog barked, and would not suffer him to touch it. When, however, the poor dog saw his master's body laid on the bullock's skin, he left the bundle, and jumped up beside his master, fondling on the dead body, and

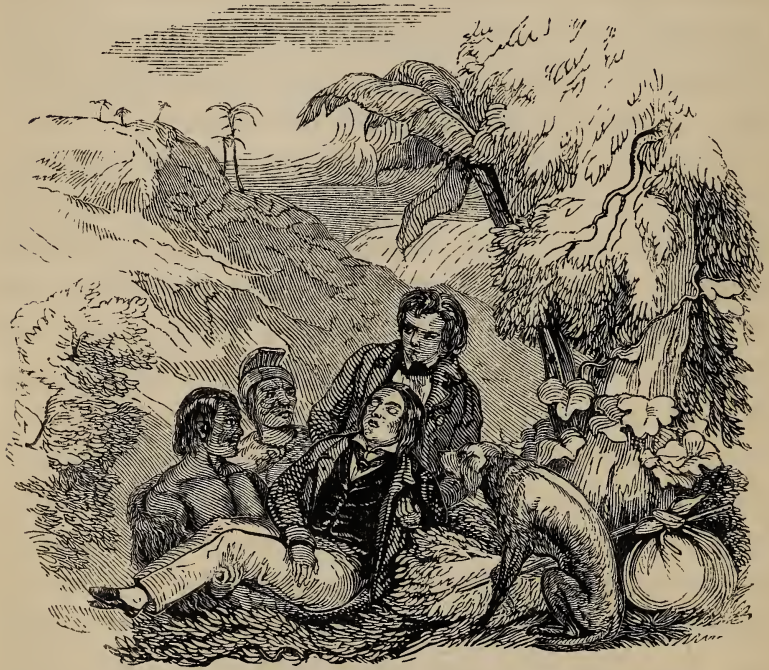

licking its hands and face. The bundle was put in beside him, and four men, each taking a corner of the skin, carried it, with all that it contained, to the 
water's edge, whence it was conveyed in a boat to the residence of the British consul at Wahoo, and there poor Douglas was buried. Many persons, hearing of the fidelity of the little dog, wished to have him, and he was given to one of the friends of his owner.

\section{QUESTIONS.}

1. Where was Douglas sent to collect plants? 2. What does the Horticultural Society of London consist of? 3. What was Douglas fond of when he was a little boy? 4. Why was Douglas chosen to go and collect plants? 5. Where did he begin his labours? 6 . What was he called by the Indians? 7. How did he die?

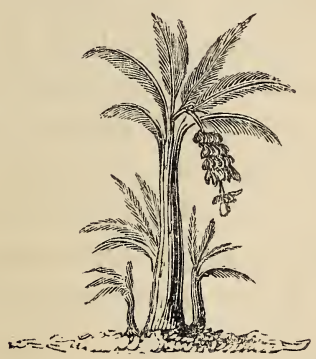




\section{CHAP. IV.}

PETER TELLS ABOUT THE DIFFERENT KINDS OF POPPY. OPIUM, AND THE MODE OF GATHERING IT. POPPY OIL, AND THE MODE OF COLLECTING OF THE POPPY SEEDS FOR MAKING IT IN BELGIUM. THE PRICKLY POPPY ; THE WELCH POPPY; THE ESCHSCHOLTZIA; THE HORNED POPPY ; AND THE GREATER CELANDINE. QUALITIES OF THE ORDER PAPAVARACEE.

\section{The Poppy Tribe (Papavaracea).}

Have you ever seen a beautiful bright scarlet flower in the corn fields, rising up among the corn, and making the whole field look at a little distance like a Turkey carpet? That is the Corn Poppy (Papaver Rhœas), the coquelicot of the French, and the plant from which the coquelicot colour takes its name. You admire this flower, and no doubt like to see it in the corn fields; but ask the farmer what he thinks of it, and you will see him shake his head, and tell you that there is no weed that gives him more trouble.

Now, shall I tell you why the farmer has so great a dislike to this pretty flower? Its roots take the 
nourishment from the ground, and its leaves prevent the corn from having room to grow; so the farmer does all he can to prevent it from ever appearing in his fields. But it is no easy matter to get rid of it. Every flower produces a capsule or seed vessel, called a poppy head, and every one of these heads contains from twenty to thirty thousand little brown half transparent seeds. So that one poppy head would be sufficient to sow the whole field; and you may now easily understand why the farmer would like his corn fields much better without their ornament of scarlet flowers.

The corn poppy is often grown in gardens, and when cultivated it becomes double, and takes a great many very beautiful colours. Some of these double flowers are fringed, some are striped, and some are quite white. Those beautiful flowers that you see in yonder bed are all corn poppies, increased in size and beauty by the rich soil they grow in, and the care of the gardener-that is, of myself.

There is another kind of poppy grown in gardens, which is called the Opium Poppy (Papaver somniferum). Fetch me one of those large double flowers from the bed on my right hand; and fetch me one from that bed on my left. Look at the two. 
They are both poppies, and not very unlike in the flowers; but see what a difference there is in the leaves. Those of the corn poppy are thin, fine, deeply cut, and covered with a soft down; while those of the opium poppy are smooth, thick, and of an oblong shape. Now, let us look at their dried heads. I have some that I can show you. The capsule of the opium poppy is large and roundish, and it is surmounted by a kind of crown curving upwards like a little cup; while that of the corn poppy is small, oblong, and covered with a flat lid. Under this lid or crown you will see little openings, like windows, through which the seeds fall out when they are ripe. Now, shall I tell you why the large white poppy is called the opium poppy? It is because it produces the drug called opium, which is sometimes given to sick persons, to still their pains and make them sleep; but which, if they were to take too much of it, would kill them. You have heard of laudanum. Well, laudanum is only opium steeped in brandy or spirits of wine; and paregoric is laudanum with oil of aniseed and camphor added to it. There is another preparation of opium, which is called morphine, which is the quieting part of the opium divided from the intoxicating part, and which is therefore thought the best for sick people. 
It is in Turkey, Persia, and India that the poppies grow that produce the opium; and there are large fields of them in these countries, planted all in rows, to enable people to reach them easily. When the petals of the flowers begin to fall, and the poppy heads are yet green and full of juice, a number of persons go into the fields, each armed with a little penknife with two blades, and with these blades they make two little scores with one stroke on each poppy, by drawing the knife upwards. This is done at night, and the next morning they go to collect the juice; which, when it first comes out, looks like milk, but which gets hard during the night, and in the morning looks almost like gum. This substance is the opium, and the Turks scrape it off each poppy head with a piece of iron like a blunt knife. They then put it in boxes, and set it to get soft in the sun; after which they knead it into little flat cakes, and pack it up in leaves for sale. They are obliged to get up early in the morning to scrape it off, as the heat of the sun would melt it.

Look! I will make a little cut in this green poppy head, from which the petals of the flower have just dropped. You see the milk follows my knife. This milk will harden in the course of the night, and to- 
morrow, when I take the poppy head off the shelf, on which I am going to lay it, this milk will have become opium, and I will show it to you. You had, however, better not touch it; as though only a very small quantity will be produced, a very little opium would be sufficient to poison a child; and if you were to eat enough to kill you, you would go to sleep, and never wake again.

The seeds of the opium poppy are not poisonous. In Germany, people eat them boiled in milk; in Italy, they make comfits of them; and in some parts of France they mix them with honey and flour, and make them into a kind of cake. In Holland and Belgium they grow poppies in fields to use the seeds to make oil. I once went to a farmer's house near Alost, between Brussels and Ghent, just about the time that the poppy seeds were ripe. Early in the morning, as soon as the dew was off the grass, the farmer called his wife, and bade her reach out all the table cloths and sheets she had clean, and give them to the servants to carry them to the field. She did so, and then getting all her children together, they all proceeded to the harvest.

"What can your wife and children do in the field?" said I to the farmer; "and what are all 
these sheets and table cloths for? Surely you are not going to sleep in the field?" "No, no, my good friend," said he, laughing; "you shall soon see what we are going to do-aye, and help us too, if you are willing." I was young then, and willing enough to help in any thing that would be of service to my

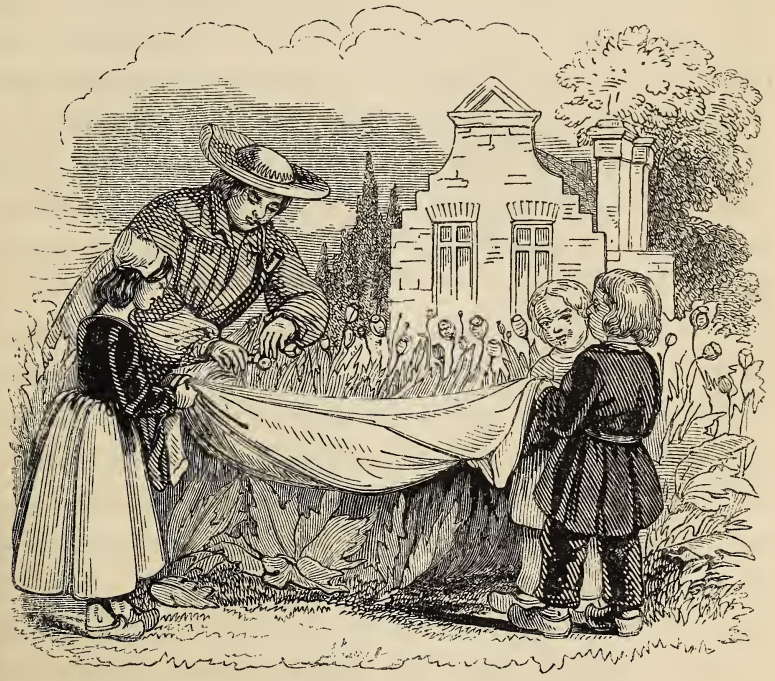

friends. So we all went to the field, and they set me to hold one corner of a table cloth, while the farmer's 
wife and two of his children held the other corners. We could not spread it out, because there was not room between the rows of poppies; so we held it curled up lengthways like a hammock. Then the farmer's eldest son went on the other side of the row of poppies, and bent every head down one by one, so that the seeds fell out, through the little holes I was showing you, on our table cloth. This was done quite fast, though I have been slow in telling it; and when all the poppies opposite the table cloth were emptied, then we carried it on to another row. And there was such laughing and singing, and we were so merry-but I was young then, and could be as merry as any of them.

When the seeds were all gathered they were taken to the barn, and left on the table cloths to dry; after which they were put into sacks, and taken to the mill to be ground, and afterwards to the press, where all the oil was pressed out of them; and then the husks that remained were given to the fowls, and made them very fat. So nothing was lost. The oil made from the poppy is very good; and a great deal of the oil sold in flasks for salads is of this kind, and not olive oil, as it is said to be. It has been calculated that all the olives that are grown would not 
make above a fourth part of the oil which is sold as olive oil.

There are a great many other kinds of poppies; but that with very large red flowers, which you see growing in my garden, is one of the most splendid. Each of its bright scarlet petals has a dark spot at its base, inside the cup of the flower. This species is called the large Scarlet Poppy (Papaver bracteatum); and there is another kind very much like it, which is called the Eastern Poppy (Papaver orientale). Nothing can be handsomer than these flowers when they first expand; but it is a great pity that they seldom last longer than a day. In warm, dry, sunshiny weather, the flowers that have opened in the morning generally lose their petals before night. When the weather is moist and dull, they do not drop so soon; but then they never look half so beautiful as they do in the sunshine.

There is a Mexican plant, the flowers of which bear some kind of resemblance to the poppy, but which has prickly leaves. This is the Argemoné Mexicana, or Prickly Poppy. Its flower is yellow; and the capsule which contains its seeds is something like a green fig covered over with sharp prickles. But its leaves are the most curious, as 
they are prickly, and curled up like those of the holly, and all the veins in them are white, while the other part is green, except a narrow white margin round the edge. This plant is a native of Mexico, the West Indies, and part of Peru; for which reason it used formerly to be called the Golden Thistle of Peru. When cut or broken, a milky juice comes out of the sten; but instead of being white, it is yellow.

There are several kinds of argemoné, the handsomest of which has large white flowers; and this is called Argemoné grandiflora. The juice and seeds of these plants are said to throw people to sleep, but I believe they are not poisonous: that is to say, I suppose they would not kill any person, unless he were to take a great quantity of them; but it is better not to run any risk, and never to put any thing into our mouths unless we are quite sure it is good to eat.

The Welch Poppy (Meconopsis Cambrica) has bright yellow flowers, of a poppy-like shape, and is very ornamental in gardens. That large orange yellow flower, with bluish green finely cut leaves, is called the Eschscholtzia Californica, because it comes from California, on the north-west coast of 
North America. This plant was one of those sent home by poor Douglas, whose story I have told you. The Eschscholtzia is a curious plant as well as a beautiful one. When the bud is going to open, the calyx does not divide into sepals, as it does in most other flowers, but it cracks at the lower part, where it joins the stem, and as the petals get longer, and ready to unfold, it rises gradually like a grenadier's cap, till at last the flower fairly pushes it off. Look at that flower of the Eschscholtzia. You see it has no calyx ; but here is one in the very act of pushing its calyx off. The seed vessel of the Eschscholtzia is like a very long and very narrow pod of very small beans; and the seeds in it are fixed along the sides like very very small dark brown fairy beans. Some people call this the Californian Poppy, but I think it is best known by its botanical name of Eschscholtzia.

When I was at Brighton last autumn, I went from that place to Shoreham, and on the road, growing on the cliffs close to the sea side, I saw some beautiful large yellow flowers, with bluish leaves. I went close to them to examine them, and I found some seed pods on the stems from which the flowers had fallen, sticking out, and curving downwards like 
horns. This was the Yellow Horned Poppy (Glaucium luteum), also sometimes called Bruisewort. Its flowers are very handsome, and the plant bears them in great abundance; but they seldom last above a day. The stem is full of a yellow milky juice, which is poisonous, and is even said to drive those people mad who swallow it.

The Scarlet Horned Poppy (Glaucium Phœniceum) is a much smaller flower, and it also very soon fades; and the Purple Horned Poppy, (Rœmeria hybrida,) fades still sooner. It is a great pity that these beautiful flowers fade so soon; but beauty is seldom lasting, at

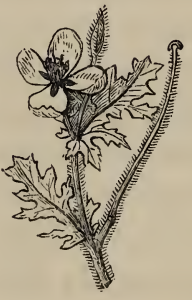

RED HORNED POPPY.

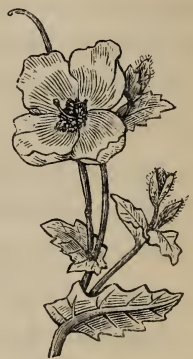

YELLOW HORNED POPPY. least beauty of this showy kind.

The Great Celandine, or Swallowwort (Chelidonium majus), has small yellow flowers, and small narrow pointed pods, like those of a radish, each of which divides into two pieces when it is ripe. This plant is a native of England, and is generally found 
in church yards and shady lanes. Its milk, when you break the stem, is of an orange colour, and very nauseous taste. I must now tell you a curious story about this plant. The country people, seeing that sparrows were fond of picking its pods, used formerly to believe that the old birds gave it to the young ones to make them see. Young sparrows sometimes having their eyelids glued together, with a kind of matter, for a day or two after they are hatched, these silly people thought they would be blind if the old birds did not rub their eyes with this herb. You laugh at this folly; but remember it was only the result of ignorance; and you would not know any better if you were not taught. So you have only to thank God, that he has mercifully permitted you to live at a time when knowledge is so easily obtained; and that he has given you parents who are able to pay for your being instructed.

I shall now only tell you of one plant more before I bid you good by till to-morrow, and that is a little American flower, that I have gathered in its native habitat on the banks of the Delaware. It is called the Canadian Blood-root, because when the root is broken, a red juice like blood issues from it; and this juice only comes from the root. This plant also is 
poisonous ; and if eaten, it would make a person feel very sick, and then a sort of faintness and stupor would come on, and if the person had eaten much he would die. Notwithstanding it is poisonous, it is worth growing in a garden, as it has a very pretty little white flower, and it is very hardy.

All these plants are said to belong to the order Papaveraceæ, that is, the Poppy tribe, because they are all more or less like the poppy. They all, when their leaves or stems are cut or broken, discharge a thick milky juice, which is sometimes white and sometimes yellow; and they all poison by stupifying. Some of them are not so poisonous as others; but all of them would destroy life if taken in sufficient quantities. In the construction of their flowers they are a good deal like the ranunculaceæ; but each flower produces only one head, which consists of several seed-pods, not distinct but all grown together; and their juice is milky and stupifying, instead of being acrid and watery.

\section{QUESTIONS.}

1. What scarlet flower is very common among corn? 2. What plant is it that produces opium? 3. What part of the plant produces 
the opium, and how is it obtained? 4. What part of the poppy is used for making oil ? 5. What country is the prickly poppy a native of? 6. What is peculiar about the bud of the Eschscholtzia? 7. What are the qualities of the plants belonging to the order Papaveraceæ?

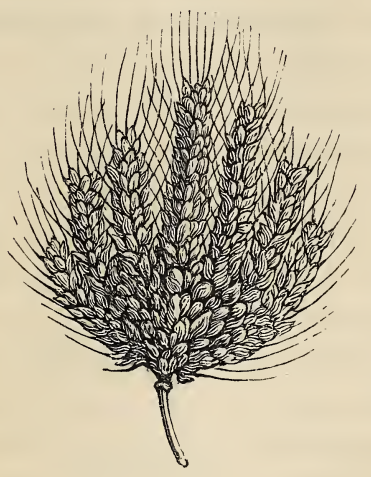




\section{CHAP. V.}

THE FUMITORY TRIBE; THE WATER LILY TRIBE; THE NUTMEG TREE. THE MAGNOLIA TRIBE. HISTORY OF THE MAGNOLIA OF MALIARDIERE.

\section{The Fumitory Tribe (Fumariacea).}

THE hedge at the bottom of my garden is nearly covered with a climbing herbaceous plant which is often found wild in woods. It is called the Climbing Fumitory (Corydalis claviculata), and its delicate white flowers, and light and graceful stems, make it very

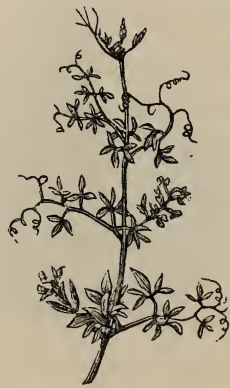

THE C:LIMBING FUMITORY.

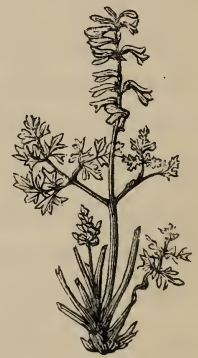

L

THE YELLOW FUMITORY. ornamental. The common fumitory of the corn fields (Fumaria media), and the Yellow Fumitory of the gardens (Corydalis lutea) also grow against my hedge, and though not very beautiful in themselves, 
they look well there. They are all natives of Britain, and though not poisonous, they are very bitter, and not good to eat. They have also a very disagreeable smell like smoke, from which the name of fumitory is derived.

\section{The Water Lily Tribe (Nymphacea).}

Who has not seen that queen of the lake, the Water Lily (Nymphæa alba)? Can any thing be more beautiful than the cream-like colour of its numerous petals, with its rich centre of broad, yellow stamens? Look, too, of what a remarkable shape its leaves are. They are round, and lie floating on the surface of the water, while the beautiful flower seems proudly to repose upon them. If we examine the water lily botanically, we shall find it very curiously constructed: the sepals of the calyx are thick and succulent like the petals, and in fact they only differ from them in being green on their backs. The stamens are also shaped like the petals, but they are narrower, yellow, and with anthers fixed to their points. The water lily, at the approach of night, closes its petals, and sinks beneath the surface of the water, as if going to bed; but when the morning comes it arises, and opens its flowers to meet the first beams of the rising 


\section{4}

PETER PARLEY'S

sun. There are many other curious things in the construction of this plant which you will understand when you are old enough to learn botany thoroughly. I am only teaching you the first steps, in order to make the road easier for you to travel when you wish to pursue it regularly.

The yellow water lily (Nuphar lutea) is more common than the white in England. It is not very handsome in its shape, but it looks well from the brilliant yellow of its flowers. There are many kinds of water lilies in different countries, some of which have blue flowers and
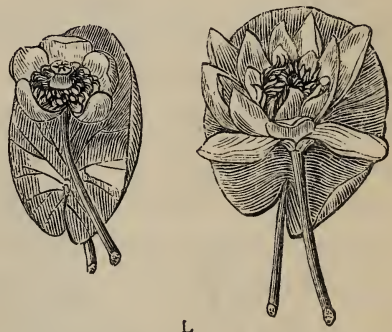
some red. One kind of yellow water lily. water Lily. water lily was also considered sacred among the Egyptians, who called it the Lotos, and dedicated it to their goddess Isis. It was also considered the emblem of fertility, because it was found on the waters of the Nile, when they overflowed the country. The seeds were dried, and then ground and made into a kind of bread, and eaten by the Egyptians, as well as the roots. The flowers of this species are large 
TALES ABOUT PLANTS.

and white. There is also a blue water lily (Nymphea cærulea), which is very fragrant, and which is found wild in the canals and in the rice grounds of Egypt, especially near Rosetta; and there is a beautiful deep rose-coloured water lily (Nymphea rosea) found in India.

Nearly allied to these is the Nelumbo or Sacred Bean of India (Nelumbium speciosum). The flowers of this plant are large and very beautiful, being either of a delicate rose-colour or white, and they smell like aniseed. The leaves are very large, being sometimes two feet in diameter; and they are round, having their footstalk in the centre. The flower rests on the centre of this immense leaf, and is thus protected from the water. The fruit is large, and filled with seeds (each of which is nearly as big as an acorn), which taste like almonds, and which are considered to have been the beans which Pythagoras forbade his pupils to eat. The root grows in the mud at the bottom of the river, and the stem is sometimes very long, as it always rises to the surface of the water before it spreads out its enormous leaf. Another and very splendid kind of water lily was discovered in 1837 in the river Berbice in the West Indies. The leaves are round, and from five feet to 
six feet in diameter, of a bright green above, and a brilliant crimson below! The flower itself resembles that of the common water lily; but it is nearly four feet in circumference, and has many hundred petals which are white on the outside, but of a deep rosecolour in the centre! It is also very sweet-scented. This magnificent plant being discovered in the same year that the present queen ascended the throne, was named, in compliment to her Majesty, Victoria regalis.

THE NUTMEG TREE.

You must all of you have heard of nutmegs and mace, and probably you may have seen these spices, but perhaps you do not know that they are both part of the fruit of the nutmeg tree (Myristica moschata). The nutmeg is the kernel, and the mace a kind of skin covering the stone. The tree is a native of Ceylon, and the Molucca

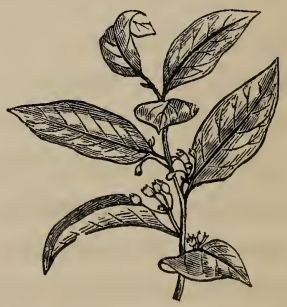
Islands. The leaves are dark green on the outer surface, and gray below. The flowers are white, 
small, and bell-shaped, and the young fruit appears inside the flower like a little red knob. After the flowers drop, the fruit gets larger and larger, till at last it attains nearly the size of a pear. When it is ripe it bursts open, and shows the bright orange-red mace, enclosing the shining jet black stone within. The nutmeg is the kernel of this stone, and it is not taken out for sale till it is sufficiently dry to rattle when shaken. The outer

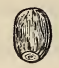
part or husk of the fruit part or husk of the fruit nutmeg. is thrown away. This tree is grown in hot-houses in England, but it has never been known to ripen fruit here.

The MagnoliaTribe (Magnoliacece).

When the first botanical collectors went to America, no trees that they found surprised them more than the Magnolias. You have seen the Magnolia grandiflora, the large flowered evergreen Magnolia. It is that tree which is trained against my cottage, and the leaves of which are so much like those of the laurel on the upper surface, but which are brownish, as if covered with rust, beneath. The blossom you see is 
very much like that of the water lily; and its fragrance is so overpowering, that you would scarcely be able to bear the scent, if you were shut up in a room with one.

My plant is scarcely so high as myself, and has only two blossoms, which are yet in the bud, though it is trained against a warm wall, and nourished with all the care I can give it; but in America I have seen Magnolia trees growing like oaks in a forest, and bearing thousands of blossoms that made the air faint with their fragrance. In America we call these trees the Big Laurels; and they grow in woods which are often several miles in extent. I am now going to tell you a story about the introduction of the large Evergreen Magnolia into France.

Above a hundred years ago, a French captain happened to go to America, and on the banks of the Mississippi he saw some woods of this beautiful tree. He was very much delighted with the splendour of the flowers, and their fragrance, and as he had a sister at home who was very fond of plants, he procured one of the young trees, and took it home with him. The tree was almost dead before it reached France, though its roots were packed in abundance of moss; and frequently moistened during the voyage. 
The residence of the captain's sister was at Maillardiere near Nantes, and there the young magnolia was planted. Its mistress valued the sickly plant as an evidence of her brother's love; and she watched and tended it, till at last it began to revive, and seemed, though slowly, to have taken root in the soil. Not long afterwards the captain was lost at sea, and his sister, who grieved much at his death, did not long survive him. Thus no one remained who cared for the poor magnolia; but as it was left unmolested it grew and flourished, and year after year it became taller and taller, till at last it shot up into a tree.

During all this time the new proprietor of the garden had fancied it a laurel; and when he saw how it grew, and how much bigger it was than other laurels, he was proud of it, as he thought it was a proof of the excellent soil and richness of his garden. One day he called to his friends to come and look at his laurel, as he had discovered a flower bud on it, quite different to anything that ever he had seen on a laurel before. His friends came and looked, and wondered, and admired; till at last one, wiser than the rest, declared that it was no laurel, and advised its possessor to consult M. Bonami, Professor of Botany at Nantes. M. Bonami was accordingly sent 
for, and the moment he saw the tree, he knew what it was, and was extremely delighted.

Now it happened that the following year there was a general meeting of the states of Brittany held at Nantes, at which all the great lords who possessed estates in the neighbourhood were present; and the lady of the highest rank who was there was the Princess de Rohan Chabet. M. Bonami took advantage of this opportunity, and procuring a branch of the magnolia covered with flowers (for the second year it bloomed much better than it did the first), he presented it to the princess. Nothing could exceed the admiration with which this branch of flowers was gazed at by all the company. The large size and snowy whiteness of the wax-like flowers and their delightful fragrance enchanted every body. All the ladies whose rank permitted them to take the liberty, crowded round the princess; while the more humble ones stood on tiptoe, and stretched their necks to obtain a glance at the precious flower.

You may easily suppose the princess was very much pleased at possessing flowers that were so very generally admired; and when she returned to Paris, which she did the next day, she took her sprig of magnolia, carefully preserved in water, with her. 
When she went to court, she wore a flower of the magnolia in her hair, and another in her bouquet; and all the courtiers were as much surprised and delighted as the princess had been herself. At last the king, Louis XV., came to look at the magnolia, and to ask the princess where she had obtained it. Now it happened that a year or two before this time, some English botanical collectors had found the magnolia in America, and had brought home seeds of it, from which a few plants had been raised; and these plants from the description which the collectors gave of the tree, sold at very high prices, ten and twelve guineas each. The French king had bought two of these plants, which were of course very small because they were so young, and he was very proud of them; though he knew it must be a very long time before they would become trees or bear flowers. This being the case, when he heard that there was a full grown tree forty feet high, and covered with blossoms, in his own dominions, his delight knew no bounds. "I must have that tree brought to Versailles," he cried; and sending for his head gardener he commanded him to have the great magnolia brought to Paris.

The head gardener shook his head, and respectfully informed his majesty that he was afraid that so large 
a tree would not bear removal. The king then sent for the first botanists in France, to consult them; but they were all of the same opinion, and at last the king, after having sent two of his gardeners to examine the tree, was obliged to let it remain where it was.

The tree of Maillardiere now had become celebrated, and no stranger visited Nantes, without proceeding to the magnolia; and the proprietor of the garden in which it stood, made so much money by selling its flowers, that he built himself a house close by it. At last, the French revolution began, and in the wars that followed, a battle was fought near Nantes; and the house behind the magnolia was set fire to by the soldiers.

You may easily suppose that while the house was burning the poor magnolia did not escape; and it was a piteous sight to see its beautiful shining green leaves parching and cracking in the fire. Then one of the branches was caught by the flames, and then another; and though they did not burn long on account of the quantity of sap in the young growing wood, the beauty of the tree was destroyed.

There are few cases so bad, but what they may be amended by patience and perseverance. When the proprietor of the tree saw what a dreadful state 
his favourite was reduced to, he did not rashly cut it down in despair, but he began to think what he could do to remedy the misfortune. He then set to work, and cut off the blackened ends of the branches, and where they were much decayed cut them in quite close to the trunk. He then laid some manure to the roots, and took care by watering to afford them sufficient nourishment to enable the tree to throw out new shoots. It did so, and in time became more beautiful than ever; its summit towering up in the centre, and its lower branches sweeping the ground. In this state it used to look like a pyramid of flowers, it having sometimes above four hundred upon it all expanded at one time. It is still in existence, but it is now above a hundred years old; and as might be expected it begins to show pretty evident marks of age.

There are a great many other kinds of magnolia. One with bluish green leaves, and a cup-shaped flower (Magnolia glauca) is called beaver wood in America; because it grows in swamps where the beavers are very abundant, and they are fond of eating its wood. They also
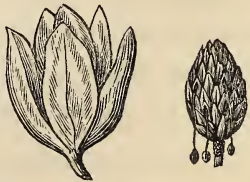

MAGNOLIA FLOWER AND FRUIT: 
build their curious dens with it; because it is so soft that their sharp teeth can cut it through like a saw. Another kind (Magnolia tripetala) is called the Umbrella tree; because its large leaves grow in tufts, each of which spreads out like an umbrella. One kind (Magnolia macrophylla) has leaves about three feet long, and nearly a foot wide; the flowers are also often eight or nine inches in diameter: and another (Magnolia acuminata) is called the Cucumber tree, because its fruit is shaped like a cucumber, and its leaves have that taste. This kind has bluish flowers, and sharply pointed leaves. Magnolia cordata has yellow flowers; and Magnolia auriculata has heart-shaped leaves.

All these magnolias have cup-shaped flowers and cones, as they may be called, which contain a great number of bright scarlet seeds. These seeds, when they are ripe, spring from their cells, and hang down suspended by a fine white silky thread. On some parts of the mountains, which the Indians call the Great Father Mountains, these trees grow so abundantly, as to make the mountains at a little distance look white with their blossoms.

There is a kind of magnolia which grows in China, and is there called Yulan, which is Chinese for the 
lily tree. The flowers are white, and come out before the leaves appear in spring; and these flowers are so abundant, that five thousand have been known in England to be on one tree at one time! This kind is called by botanists Magnolia conspicua. Magnolia fuscata is also a native of China. It is a little plant generally kept in a pot in a greenhouse; and, even in China, it.seldom grows above four feet high. It has little dark purplish brown flowers which have a very delightful smell. There are also two magnolias, which are natives of Japan, the purple flowered (Magnolia purpurea), and the Kobus, or slenderbranched (Magnolia gracilis); but the flowers of both these kinds are neither so large nor so abundant as those of Magnolia conspicua.

\section{THE TULIP TREE.}

Now come into my garden and look at the leaves of this tree. You see how curiously they are shaped. They look as if the points had been cut off, and indeed the whole leaf is something in the shape of a saddle. My tree is very small; but if you had been with me in the American woods, you would have seen Tulip trees taller than the oaks. I have seen them a hundred feet high, covered with their curious 
yellow, white, and reddish flowers which look like little tulips, and their cones of reddish seeds.

When the tulip tree was first discovered by the English botanical collectors in America, they fancied it was a kind of poplar; from its wood, when the tree was cut down, being something like that of the poplar, but more yellow: and the wood of this tree in America is called poplar wood to this very day. The wood is used in America for a great variety of purposes; and among others for making shingles, which are a kind of wooden tile used for covering houses in a country where wood is much more plentiful than brick. When a tulip tree is cut down if the chips of the heart wood are left to decay on the ground, covered with the leaves, so as to be moist, they become of a beautiful blue, and smell like hartshorn. The first tulip tree that was brought to England was placed in a pot, in a greenhouse! when as may be supposed it soon died. Others were brought and planted in the open ground, where they soon grew to be a good size.

Both the tulip tree and the magnolias belong to the natural order Magnoliaceæ, and are, as well as the other plants belonging to it, distinguished by their seeds being produced in cones, and by the 
manner in which their leaves are folded up, in what is called a spathe, before they unfold. Their bark is used in America, for strengthening persons who have been ill, and are getting better, as the Peruvian bark is here.

One of the finest tulip trees in Europe stands in the gardens of the palace of Lacken near Brussels. When this palace was in the possession of Buonaparte, the empress Josephine resided there a short time. Josephine was very fond of flowers, and she had a splendid collection of foreign plants in her palace at Malmaison near Paris. When she saw this splendid tulip tree she was quite delighted; and when she found it was the only one in Europe that had borne seeds, and there were actually ripe seeds then upon it, she was quite enraptured. "I must have those seeds," said she. In vain the gardener represented that they were on the topmost branches; and that they would be difficult and dangerous to reach. She insisted on his trying. Several long ladders were procured, and they were tied together till a very long one was made and reared against the tree. The poor gardener sighed and again represented the danger, but was ordered imperiously to ascend. He did so, and had almost reached the top, when stretching 
forward to secure the seed, the ladder slipped, and he fell from the height of seventy feet. Of course, he was killed, and the empress, who had been watching eagerly for the seed, burst into tears, when she saw what her folly had done. She told her attendants to try to revive the poor gardener; but it was too late, for the blood gushed out of his nose and mouth, and he was soon quite dead. The empress was very sorry, and gave a pension to his wife and children; but during the rest of her life she repented the unreasonableness and folly she had been guilty of. Let us learn from this, when we wish any thing that our reason tells us we ought not to have, to consider whether we may not find a moment's pleasure dearly bought by an age of repentance.

\section{QUESTIONS.}

1. What other spice belongs to the same tree as the Nutmeg? 2. Of what country is the nutmeg tree a native? 3. What is remarkable about the seed of the magnolia? 4. What countries do the magnolias come from? 5. What other remarkable tree, besides the magnolias, belongs to the same natural order? 6 . In what are the seeds of the order Magnoliaceæ produced? 


\section{CHAP. VI.}

UMBELLIFEROUS PLANTS. STORY OF PETER THE WILD BOY. STORY OF THE SHIPWRECKED SAILORS. RAPID GROWTH OF THE SIBERIAN COWPARSNIP.

UMBELLIFEROUS PLANTS, OR THE PARSLEY TRIBE.

$$
\text { (Umbelliferc.) }
$$

You have probably seen Parsley when in flower or in seed; and if you have, you must have observed that it spreads out so as to make a large broad head. This head is what botanists call an umbel. Now the plants that I am going to tell you about to day, are all more or less like the parsley; and they all have their flowers and seeds in large heads or umbels, for which reason they are called umbelliferous plants, and are said to belong to the natural order Umbelliferæ.

Many of the plants belonging to this order are deadly poisons; and others, which are poisonous in a wild state, become eatable by cultivation; while others are not poisonous even when wild. It has been observed that all the umbelliferous plants which grow wild near water, or in marshy ground, are 
poisonous. Some of these plants so strongly resemble parsley and celery that many persons have been poisoned by mistaking them for those vegetables. As knowledge advances, however, these unfortunate mistakes will be less frequent; as a very slight knowledge of botany will be sufficient to teach that all herbaceous plants bearing their flowers in umbels are dangerous in a wild state. The number of the umbelliferous plants is so great, that I can only attempt to describe a few of the commonest and best known.

Marsh Pennywort (Hydrocotyle vulgaris) is a little creeping plant with round leaves, and small compact umbels of pinkish flowers. It grows in moist meadows; and, because the sheep feeding in such meadows frequently have the rot, this plant was supposed to give it them, and hence it was called Sheep'sbane and Whiterot. The fact is, however, that the sheep will not eat it.

Sanicle (Sanicula Europæa) is very common in English woods, and it was formerly held in very great esteem for its supposed power of healing wounds. It was called sanicle from the Latin word sano to heal; and even now, in woods in retired country places, old women may occasionally still be 
seen looking out for its dark green glossy leaves shining among the decaying refuse of the year, to gather it for poultices. Many, many years ago, people fancied that drinking water in which it had been steeped, would cure their cuts and wounds, without applying any dressing to them; but this strange fancy has long since passed away.

The Eryngo (Eryngium maritimum), or Sea Holly, grows on the sea shore, in the loose sand, which its long creeping roots help to bind. The whole plant is of a bluish green, almost like the colour of the sea it grows so near; and its heads of flowers are like little round lumps rather than spreading umbels. The root is considered wholesome and strengthening, and it is sold by the druggists candied, that is, dipped in syrup of sugar, and then dried. It is a curious circumstance, that candied eryngo, having been first made at Colchester, is still made there better than any where else; and that almost all this sweetmeat used in Britain is procured from one of the descendants of the person by whom it was first made.

Water Hemlock, or Cowbane (Cicuta virosa), is a most deadly poison. It grows in marshy ground at Isleworth, and several other places in the neighbourhood of London; and as it has no bad smell when it 
is quite young, cows sometimes eat it, and die in consequence. It is what is called an acrid poison, and burns and destroys the coats of the stomach. If any one were to eat it, the only way to prevent death would be to swallow a great quantity of oil, so as to occasion sickness.

You will be surprised to hear that Celery (Apium graveolens) grows wild in Britain, as you know that gardeners are obliged to take a great deal of trouble to make it grow in gardens; but the fact is, that the wild celery, which is called Smallage, and which grows in ditches in Britain, is so unlike the cultivated sort, that no one would suppose them to be the same. It is also not only unlike in appearance, but in qualities. The garden celery is mild and wholesome; but the smallage is acrid, and even poisonous, if taken much of. When gardeners cultivate the celery, they make deep trenches, and plant it at the bottom. They then, as the plants grow, draw the earth round them so as to keep the stems constantly covered, and to leave only a little tuft of leaves visible at the top. Covering the stems in this manner with earth not only whitens them, but it makes them mild, crisp, and good to eat. Parsley (Apium petrosilinum) belongs to the same genus as 
celery, and there is a kind of parsley brought from Hamburgh, the root of which is eaten. The common parsley is a biennial; that is, it does not ripen its seed till the second year after sowing. It is a native of Sardinia, and was introduced into England about three hundred years ago.

Fool's Parsley (Æthusa Cynapium) is a very poisonous herb; and as it often comes up wild in gardens among the other parsley, I will tell you the difference between them. When in flower, the fool's parsley has two long beards hanging down from each flower, while the common parsley has none. The divisions of the leaf of the fool's parsley are narrower and more pointed, and the leaves are of a darker and much bluer green. The smell of the fool's parsley also resembles that of garlic. You see there are several ways of finding out the difference between these plants; and it is because there are so many, and yet that mistakes have been so often made, that the poisonous plant is called fool's parsley; as it is supposed that only foolish people, who do not pay proper attention, could take the one for the other.

Would you like to know what carraway comfits are made of? They are made of the seeds dipped in sugar of an umbelliferous plant, called the Carra- 
way (Carum Carvi). Here is a sprig of it, with one umbel showing the flowers, which are white, and the other the seeds, the husks of which are brown. The carraway is called Carvi in France, and Kümmel in Germany ; and in both places it is used with white brandy to make what is called a liqueur. In England the carraway is cultivated for its seeds, some of which are used by the

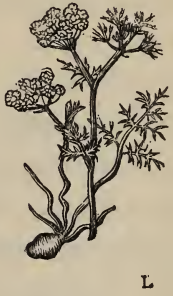

EARTH NUT.

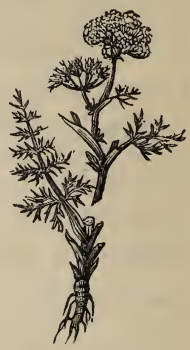

CARRAWAY PLANT. confectioners, as before mentioned, to make carraway comfits; and others are pressed to extract their oil. Carraway seeds are also used for putting into cakes and biscuits, as no doubt you well know.

Large fields of carraway plants are grown in Essex, like corn. The seeds are ripe in August, and they are so small, that if great care were not taken in gathering them, a great part would be lost. To prevent this, women and children are employed to cut off the head of each plant separately, and to put it into a linen cloth, which is held to receive the heads in the same manner as cloths are held for the poppy 
seeds in Flanders. These cloths are then carried to a spare place in the field, where there is a large piece of sail cloth. Here the thresher stands with a small flail in his hands, with which he gives each bundle two or three blows, which is sufficient to get all the seeds out; and then he is ready for another. The seeds are then carried to the barn to dry, and afterwards they are packed up in sacks for sale.

The roots of the carraway are long, like those of a carrot, and they used formerly to be eaten boiled like carrots. About two hundred years ago, it was more common to see boiled carraway roots on English ta.bles than parsnips; and yet now many persons would scarcely believe that any one could ever have thought of eating them. Coriander (Coriandrum sativum), and Cumin (Cuminum cyminum), are also cultivated in the same manner for their seeds, though the latter is grown in the south of France, and not in England.

I never see earth nuts without thinking of the story of Peter the Wild Boy, who was so fond of these nuts, that he suffered himself to be caught by them when he did not care for any thing else. Did you ever hear his story? If you have not, I will tell it to you. 
HISTORY OF PETER THE WILD BOY.

About a hundred years ago, a farmer in Hanover, having lost one of his cows, went into a wood to look for her. After searching a long time, he at last saw his cow at a distance, standing quite still in the midst of the forest. Overjoyed, he ran up to the place where she stood, when, to his great surprise, he saw a naked boy, apparently about twelve years of age, kneeling down and sucking her like a calf. You may easily guess how surprised the farmer was, and he was still more so when he looked at the boy. The boy stared at the farmer, and the farmer at the boy, and it was no wonder that he did so, for you never saw such a boy in your life. His hair hung loosely over his shoulders, his body was quite naked, and covered with hair, and the nails of his hands and feet were like claws.

I said the farmer looked at this strange boy, and the strange boy looked wildly at him. At last the farmer spoke to him, and then the strange boy, uttering a shrill cry, ran up a tree like a monkey.

The farmer, who was very much frightened, drove his cow home, and told his neighbours what had 
happened; and the news excited so much attention, that it soon reached the ears of the burgomaster of

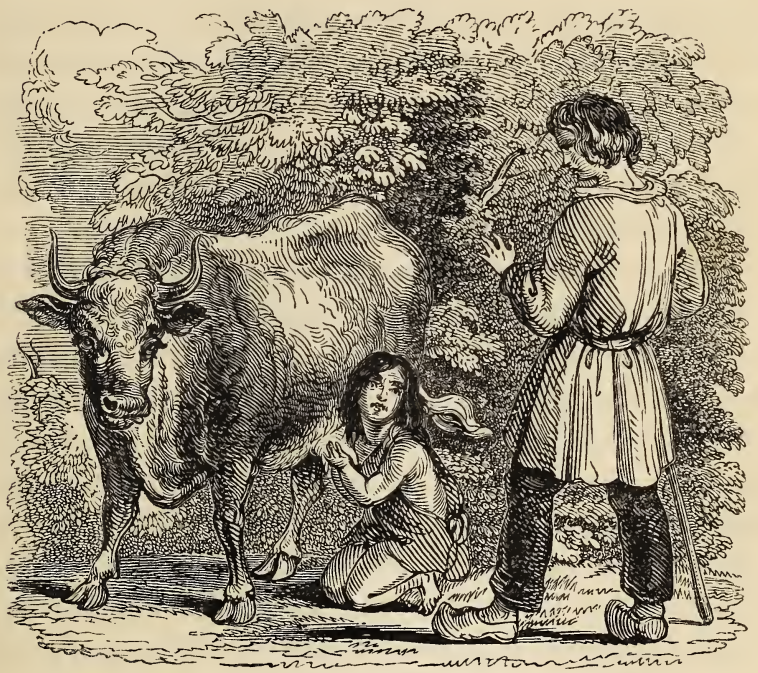

the town, who sent people into the woods to try to catch the wild boy. They soon found him, but he no sooner saw them than he ran up a tree, too high for them to climb after him; and there he sate grinning and making faces at them, and pelting them 
with boughs like a monkey. Nothing that they could think of would tempt him down. They laid food of all kinds-apples, and I know not what bebesides-at the foot of the tree, but he did not care for them. At last some one thought of earth nuts, and a quantity of fine ones, just dug out of the earth, were laid at the foot of the tree. The moment the wild boy saw them, his eyes sparkled, and he darted down to seize them.

Of course he was now easily caught, and carried to the town, being indulged with his favourite earth nuts to eat on the way. Nobody at first could imagine where this wild boy came from, but at last it was recollected that a little boy only two years old, whose parents were dead, had, several years before, wandered into the woods, and never been heard of since. It was supposed that the wild boy might be this child, but if it was, no one could tell how he had lived till the time he was found.

Whatever might be his origin, the wild boy was very kindly treated in the town, and was dressed in good clothes, and well fed. He never liked any thing, however, so well as earth nuts, and he would leave every thing if he saw them. The boys in the town called him Peter, and he learnt at length to 
call himself Peter: but he never could be taught to pronounce any other word. He was, however, very fond of music, and would jump about with great delight when he heard any one playing. He was afterwards sent to England, where he remained till his death.

I have told you the story of Peter the Wild Boy, because he was so fond of earth nuts; and I will now tell you something about the roots he was so fond of. The Earth Nut (Bunium flexuosum) is very common in woods in England, and in many parts of the continent. It is sometimes called the pig nut, because pigs are remarkably fond of it; and when they are turned into woods, they root up the pig nuts with their long snouts, and eat till they make themselves quite fat. I do not suppose you or I could eat a raw pig nut, though Peter the Wild Boy did; but when pig nuts are boiled, they are very good, and when roasted in the ashes, they are almost as nice as chestnuts. In Holland and Switzerland they are put into soup to thicken it.

If you remember, when we were speaking about making laudanum from poppies, I told you that to make elixir of paregoric, the laudanum was mixed with camphor and oil of aniseed. This oil is made 
from the seed of an umbelliferous plant called Anise (Pimpinella anisum), which is grown every year in large quantities in Malta and Spain, in fields, for the purpose of gathering the seeds for sale. Formerly, that is, about three hundred years ago, people in England fancied that holding a sprig of aniseed in the hand would cure a disease called the falling sickness; but people are now wiser, because they are better informed.

There are other kinds of Pimpinella, which are called Burnet Saxifrage, and some of which are considered so good in salads, that the Italians have a proverb which says, What is a salad without burnet?

There is a kind of umbelliferous plant called Skirret (Sium sisarum), the tubers of the root of which are very good when boiled, and served up with melted butter or milk. They are often dressed in this manner in France, and also in the north of Scotland, where they are are called crummock. There is another plant of the same genus which is poisonous, and is called the Water Parsnip (Sium angustifolium); but there is not much danger of its being mistaken for the skirret, as the water parsnip grows in water. The Water Dropwort (Enanthe crocata) 
is a much more dangerous plant, as it looks so much like celery that many persons have died from eating it, having mistaken it for that plant. This plant is so strong a poison that many persons have felt giddy merely from smelling it.

The common Fennel (Fœniculum vulgare) is well known from its use with mackerel; but there is a kind, scarcely ever grown in England, which is common in Italy, and is called there Finnochio. The Italians are very fond of the stalks of this plant, which they blanch like those of celery, and eat sliced with oil, vinegar, and pepper, as a salad. Dill (Anthemum graveolens) is a plant greatly resembling fennel.

The Samphire (Crithmum maritimum) grows on the rocky shores of the sea, in places where there does not appear enough earth to support any kind of plant. Its long string-like roots, however, twine about the rocks, penetrating into every fissure they can find, and throwing out bunches of leaves and flowers in places where no human foot could tread. For this reason, it is extremely difficult to gather this plant, which is used for making pickles; and the people employed for this purpose are obliged to suspend themselves from the rock above. When this 
is to be done, several persons repair to the cliffs, with a rope often above one hundred feet long, which one of them fastens round his body ; and taking a basket and strong stick in his hands, he is let down by his companions, who place a piece of wood on the brink of the rock, to prevent its edge cutting through the rope. Thus prepared, the samphire gatherer descends, and steadying himself with his stick, which he thrusts into the fissures of the rocks, he gathers the plants he wishes. When he has gathered all he can reach, he shouts to his companions, who draw him up.

The samphire is called, in France, the Herb of St. Peter; and it is from the French name Saint Pierre, that our name of samphire is derived. The samphire, though it grows on the rocks close to the sea, never grows in the water, and a knowledge of this fact was once the means, under God, of saving the lives of four men.

One stormy night in November, 1821, a vessel was wrecked near Beachy Head, and every one on board washed overboard. Four of the crew reached some low rocks, on which they kept their footing; but in the darkness of the night, and amidst the fearful howling of the storm, they knew not whether the 
rocks they were upon were part of the main land, or at some distance from it in the sea, and covered at high tide with water. They feared the latter; and as they saw the water gradually advance upon them, they were seized with despair, and could not have held their footing much longer, had not one of them, clinging to the highest point of the rock, grasped in his hand a weed, which he saw, by the flashes of lightning, was a piece of samphire. He knew that the samphire always grows above the water, and consequently that this point of the rock must always be above the sea. He told his companions, and these poor creatures, in the transports of their joy, mingled their praises and thanksgivings with the wild howling of the winds and waves, and the roaring of thunder. They soon found that the tide had turned, and that their place of refuge was left high and dry; and they fell upon their knees to return thanks to that Almighty Being, who, by means of a simple weed, had saved them from despair.

The common Angelica (Archangelica officinalis) is a native of Britain; but it is grown in gardens for the sake of the young tender green shoots, which are very nice to eat when they are candied with sugar.

The Parsnip (Pastinaca sativa) is also a native of 
Britain ; but in its wild state it is very different from what it is when cultivated. It is excellent for the table; cows are very fond of it, and it produces very rich milk; wine may be made from it, and also a sort of brandy; and as it contains a great deal of sugar, cattle, pigs, and poultry, will soon get fat by eating it. It is much grown in Catholic countries for eating with salt fish during Lent.

The common Cow Parsnip (Heracleum sphondylium) is a coarse growing plant which cattle are very fond of. The seeds have a very strong and disagreeable smell. Another kind (Heracleum asperum), the Siberian Cow Parsnip, is one of the most rapid growing plants I ever knew. A friend of mine gave me some seed which I sowed in my garden, and a plant came up which expanded two or three leaves in the course of the summer, but these withered away. There must be some mistake about this, thought I, instead of being so beautiful as my friend described, this cow parsnip is not so good as the common sort.

Time passed away, and the next spring I made a kind of pond or basin in my garden to hold a little water for my plants. This pond was very near the cow parsnip, and I suppose its fibrous roots reached it. However, one day I saw the ground cracking and 
opening, and in a day or two a great bud pushed itself through. The next day the bud had opened into leaves; then the stem began to appear; till at last in less than two months my Siberian cow parsnip was fourteen feet high; with a great head of umbels that measured above twelve feet round. Its stem was like the trunk of a tree; and its great leaves spread like umbrellas.

The common Carrot (Daucus carota) is also an umbelliferous plant. I suppose I need not describe either its appearance or its use; but I may tell you, what most probably you do not know, that there is a white carrot, and a purple one; both of which are very good to eat. The seed of the carrot is very light; and it is generally mixed with sand, to separate it, before it is sown. Carrots, when cut into pieces, and boiled with sugar and ginger, are very much like the preserved ginger that comes from the West Indies; and are very good. The Wild Carrot is a native of Britain ; but, like the parsnip, it is very different from the kind grown in gardens.

There are a great many other umbelliferous plants ; but it would take me too long to tell you about them all. There is the Hemlock (Conium maculatum), which is a deadly poison, and has been often mistaken 
for parsley. This plant was known to the ancient Greeks, and was the poison taken by Socrates. The garden Chervil (Anthriscus cerefolium), so much used for salads in France; and the wild Chervil (Anthriscus sylvestris), which is poisonous, and which has frequently been mistaken for it. The Shepherd's Needle (Scandix pecten), or Venus's Comb, a very curious plant, though a common weed, from the long pointed beaks of its seed vessels standing up like the teeth of a comb. The Arracacha Earth Nut (Arracacha esculenta), the tubers of which are eaten in South America as commonly as potatoes are with us. The Prangos Hay plant (Prangos pabularia), which is used for hay in the East Indies; and the Assa-fœtida plant (Ferula assa-fœtida), from the juice of the root of which the gum thus called is obtained. This plant is a native of Persia, and it grows there five feet or six feet high. When the leaves begin to decay, the root is laid bare; and after a time part of it is cut off. The juice issuing from the cut is the Assa-fœtida, hardened in the sun; and when it is sufficiently firm it is scraped off, and packed in boxes for sale. Gum Ammoniac is also the produce of a Persian umbelliferous plant (Dorema ammoniacum); and several other gums or resins used in medicine are produced 
by plants of this order. I will not, however, tell you any more of these plants, as I think you have heard of quite as many as you are likely to remember.

\section{QUESTIONS.}

1. What are the characteristics of umbelliferous plants? 2. What kind of umbelliferous plants are most poisonous? 3. What are the points of difference between the common parsley and fool's parsley? 4. Where are carraway seeds principally grown? 5. What is peculiar about samphire as to its places of growth?

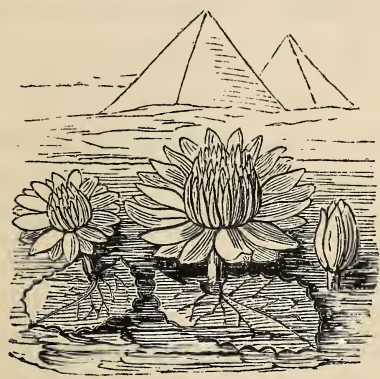




\section{CHAP. VII.}

THE IVY ; GOOSEBERRIES ANDCURRANTS. THE BARBERRY. THE VINE. GATHERING THE GRAPES AND MAKING WINE. DRYING RAISINS AND CURRANTS. THE VIRGINIAN CREEPER, OR FIVE-LEAVED IVY. THE PITCHER PLANT, AND THE EVENING PRIMROSE TRIBE.

\section{THE IVY.}

There are several different kinds of Ivy grown in British gardens, but they are all varieties of one species, Hedera helix. Helix is a droll name to give to a plant, for it is the scientific name of the snail; but it is from a Latin word signifying to turn round, and it is given to the ivy, because it turns and winds round trees; and to the snail because its shell seems also to have made many turns. The different kinds of ivy are principally distinguished by their leaves and berries. You know the leaf of the common ivy; well, when the ivy takes a tree-like form, and sends up a leading shoot instead of trailing its branches along the ground, or over a wall, its leaves become heart-shaped, like this, and these kind of leaves are 
always found on the shoot which bears the flower stalk.

The flower of the ivy is very like that of some of the umbelliferous plants; but it does not belong to that order, because it bears berries, which they do not. The berries of the common ivy are black, but there is another kind with yellow fruit, which grows in India. Besides these, there are the gold and silver-leaved ivy, and the palmate, or hand-shaped ivy. The gold-leaved ivy is very beautiful; there is a plant of

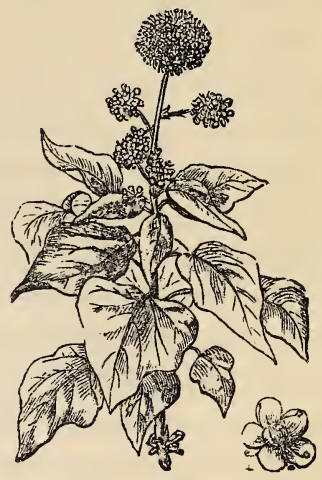

TREE IVY. it at Lee's nursery, Hammersmith, trained up against the back of one of the hothouses; which, in spring, when it has just made its new leaves, looks, to my old eyes from the road, like an immense mass of yellow flowers.

The Tree Ivy is only the leading shoot of the common ivy trained up, and the trailing shoots cut away, so as to throw all the strength into the stem. There is a plant of the tree ivy in the London Horti- 
cultural Society's garden at Chiswick, which shows this; for while the tree part grows up with heartshaped leaves in the middle, the lower part trails with its half palmate leaves on the ground.

The Giant Ivy only differs from the common kind in having larger leaves. It is generally called the Irish ivy; but why I am sure I do not know, for the plant is a native of the Canary Islands. The common ivy is a native of Britain, and in short of every other part of Europe.

The flowers of the ivy afford food for the bees in summer; and the berries are a delicious treat for the birds in winter. The plant itself covers walls and houses, or spreads over the ground, or it climbs up trees, compressing them with its stems, which, as the tree grows and expands its trunk, become buried in it; and when the ivy is taken away, leave a deep indentation in the tree it had climbed round. Birds are very fond of roosting in ivy ; and towards evening, when I sit at the window of my cottage, looking into my garden, I see the little birds come one by one, and first perch on that birch tree opposite to us, swinging their little bodies to and fro, on its slender branches, and looking carefully about to see that no danger is near; and then popping into the ivy that covers my 
verandah. The ivy belongs to the natural order Araliaciæ.

Gooseberries and Currants, or the Gooseberry Tribe (Grossulacea).

I am now going to tell you about the plants belonging to the natural order Grossulaceæ. Do you know what these are? No ; well then, I will tell you-they are gooseberries and currants. Ah! you think that you know all about them now; but you are mistaken. I am going to tell you some things about them that I think you do not know; and there are many other things that might be told of them that I do not know. However, what I do know will be enough for our present purpose.

The common Gooseberry (Ribes grossularia) grows wild in France, Germany, and Switzerland; and it is also said to be found wild sometimes in Britain, but I never saw it growing without culture in this country. It grows also in India, and in North America; for I once gathered some from the rocks near the falls of Niagara. You must not suppose, however, that these gooseberries were like the delicious ripe fruit which you gather in gardens. No, they were hard, hairy, and with scarcely any taste; and what taste they had, 
was of a bitterish sour. I see you will be contented with the cultivated sorts, and not wish to taste the wild ones.

The gooseberry is called feaberry in some parts of England. This is a corruption of fever-berry; because its juice is cooling, and pleasant for people to eat, when they have fevers. It is called gooseberry, because it was formerly always eaten as a sauce to green geese; and in France, it is called Groseiller à maquereau, because it is eaten as a sauce to mackerel.

The largest gooseberries in the world are grown in England; and the principal places where they are grown are Lancashire, and Huntingdonshire. In Lancashire, the weavers are the principal gooseberry growers; and when they want to get a very large gooseberry to win a prize at a show, they choose a tree about four years old from the cutting. They then take all the gooseberries off the tree, except three or four of the finest. They afterwards lay manure round the tree, and water it, and even put saucers of water under the fruit that the evaporation from the water may serve to swell the gooseberries; and by these means they often make their gooseberries as big as a small magnum bonum plum. 
There are a great many varieties of the common gooseberry, some of which have very ugly, and I think, silly names. One of the largest red is called the Roaring Lion; a very large white one is called the Eagle, and another Wellington's Glory; Rockwood is one of the largest yellow; and Ocean one of the green.

Besides these varieties of the common gooseberry, there are a great many different species. One of these (Ribes speciosum,) has bright scarlet blossoms something like a fuchsia. Another kind (Ribes diacantha) bears gooseberries in bunches like currants; and another (Ribes niveum) has white flowers, and bears fruit of the colour and size of the black currant, but with quite the flavour, and the appearance when cut open, of a gooseberry.

I am now going to tell you about the Currant, and you will perhaps be surprised to hear that there are as many kinds of currants as there are of gooseberries. You know that there are red currants; but perhaps you did not know that the white, the pale pink, and the striped are only varieties of that species. There are also several species which bear red currants, besides the common kind (Ribes rubrum). There is the Tree Currant (Ribes spicatum) which grows wild 
in England, and bears its fruit on an upright spike, instead of in bunches hanging down. The Longflowered Currant (Ribes multiflorum), a native of Croatia, is very beautiful, though its flowers are only green, from the graceful manner in which the long racemes hang down. Then there is the Creeping Currant (Ribes prostratum) which creeps along the ground like the ivy; and bears fruit that one must kneel down to look for as we do for strawberries. This is a native of Canada; I have seen it wild in the woods there. The Evergreen Currant (Ribes punctatum) bears bunches of beautiful bright yellow flowers, and shining green leaves, (as smooth and shining as those of the laurel though of a different shape) which remain on the tree nearly all the year. This plant is a native of Chili in South America.

The Black Currant (Ribes nigrum) is now in almost every garden; but rather more than two hundred years ago, Gerard, who wrote a book on plants, spoke of it as having uneatable and loathsome smelling fruit. There are a great many species of black currants. One of these, the red-flowered currant (Ribes sanguineum), is very beautiful. In the spring it is covered with long bunches of bright pink or scarlet flowers; and is one of the greatest orna- 
ments to our flower gardens. The fruit is small and black, with a down on it like a plum; it is not very good, but the plant is a great favourite everywhere on account of its beautiful flowers. There are several varieties of this species.

There are several kinds of black currant with large white flowers; and one of these (Ribes cereum) has round leaves, with white waxy dots like scales on their upper surface. The golden-flowered currant (Ribes aureum) has bright yellow flowers, as have its varieties and allied species; and their fruit is black or of a dirty yellow, and not very good; but the flowers are very pretty.

Now have I not performed my promise of telling you a great deal about gooseberries and currants that you did not know before? I think I have, and that you had no idea that there were so many different sorts. There are, however, a great many more; though it would take me too long to describe them all. Now come into my arbour, and try if you like gooseberries and currants any better for hearing so much about them; and while you are eating them, I will tell you about some other plants. 


\section{The Barberry Tribe (Berberidece).}

The bright red berries of the Barberry hang in bunches like currants; but they are long instead of round, and if you were to taste one you would soon find the difference. They are, however, very nice preserved in sugar, or candied; and if you ever go to Paris, and enter a confectioner's shop there, you will find that some of the nicest sweetmeats in the world are made with barberries.

There are many varieties of the common barberry, (Berberis vulgaris) which differ in the colour of their fruit. Some are white, some yellow, some purple, some violet-coloured, and some black. They grow wild in different countries, and either the common barberry, or some of its varieties, may be found in almost every country all over the world.

Go to that barberry bush in the garden, and bring me a bunch of its pretty yellow cup-shaped flowers. Take care, however, of the thorns; for they are very strong and sharp. These thorns, or spines, as they are more properly called, always come out in threes, and at the same place as the leaves, which are in threes also. So that when the plant is in leaf, there are from each bud three leaves and three spines. 
Now let us look at the flower, for I am going to show you something curious about it. Inside the cup are six stamens, which lie back upon the petals as if reposing themselves; and in the centre is a little green knob which is the stigma. The stigma sits in the centre as a queen, and the stamens seem standing at a respectful distance round her, as her attendants. Now give me a pin. With this I just touch one of the stamens, and see it comes forward, and bows to the queen, and then falls back again. Here take the pin, and make another do the same; you must only just touch it.

This is very curious; and what is more so, is, that botanists cannot give any reason for this irritability of the stamens. There is another curious fact about the barberry, and that is, it may be poisoned like a living being: if you boil poppy heads and put the liquor to the roots of the barberry, the stamens will lose their power of moving; they will become flaccid, and seem stupified and insensible as a man would be who had drunk the same decoction: and if you pour any corrosive liquid to the roots, the stamens in a few hours will seem swelled and inflamed.

The barberry is often affected by a kind of mildew; and it was formerly supposed that if there were any 
barberries in the hedge of a corn field, the corn would catch the disease from the barberries, and become infected also. But this is quite a mistake; and is as great a one, as if any person were to tell you that you would catch the hooping cough, if you went near a person who had the small pox. The corn has a mildew, but it is of quite a different species to that of the barberry.

Do you know what the mildew is? It is a small fungus which grows on the leaves of plants; so very small as to look, at first sight, like only an accidental stain on the leaf; and which can only be discovered to be a plant by the aid of a powerful microscope. I shall tell you more about these mildews by and by.

There are a great many different kinds of barberry; one (Berberis Asiatica) bears a great quantity of flowers, and produces fruit with a bloom upon it, and as large as some kinds of raisins. This species is a native of Nepaul, where its leaves and stems are used for dying yellow. The fruit of this species, and also that of Berberis aristata, also a native of Nepaul, are dried in the sun by the natives, like grapes, and are kept for winter use.

The Holly-leaved Ash Barberry (Mahonia aquifolia) is a magnificent-looking plant. It has prickly, 
shining, dark green leaves, like a holly; and a profusion of bell-shaped yellow flowers. It is an evergreen, and one of the finest plants that can be grown in a small garden. There are many other kinds of ash-barberry, all very beautiful; but none quite so much so as this.

\section{The Vine Tribe (Vitacea).}

Who is there that has not heard of the Grape-vine, and who does not know that wine is the fruit of the grape? I need not say much, I suppose, about the grape. You know what those tempting bunches of very dark purple or whitish berries are which we so often see hanging from the roofs of hot-houses, or even at the doors of the grocers' shops. And you know also that these berries in France and Germany, and other countries, are grown in the open air in what are called vineyards, and their fruit when it is ripe is gathered to make wine.

Have you ever seen a vineyard? No, you have not. Then I will describe one to you, in which I saw the grapes gathered in the south of France. The vines were all planted in rows, and tied to sticks as hops are in this country, but not so high; and they were loaded with a number of bunches of fine 
ripe rich grapes. Several old women, brown with the sun, in short petticoats and with high heeled shoes, were trotting up and down between the rows of vines, each with a small hooked knife in one hand, and a basket in the other. The basket she set on the ground under each vine in turn, and cut off the bunches of grapes one after the other, to put into it.

Then came a great stout man with a large basket on his back, like what they call in Scotland a creel; and as he passed along the rows each old woman emptied her little basket into his large one. As soon as this was full, he went to the cart, and emptied it, and came back for more. Now this cart was not like what you may have seen in fields in this country. It was a great hogshead set on wheels; so that when the man threw the grapes into it, the juice was not lost, but kept in the cask. I should have told you also that the man's creel was not of wicker work, but of wood; so that the juice did not run from it, any more than from the cask.

When the cart was full, it was taken to the press; and this was a great pit, with a wooden cover, which was raised up and down by a screw. The lid was raised quite high while the grapes were being put into it, but as soon as it was full, the great screw 
was turned by means of a horse going round and round, and as the lid pressed on the grapes, the juice ran from them, through a kind of spout in the pit, into great tubs placed to receive it. When all the juice had been pressed from the grapes, the skins and seeds were given to the fowls, and these fowls were the nicest and fattest I ever tasted.

The wine after it is drawn from the grape is at first sweet, and not at all strong; but it is put into casks, which are not closed up, and left to ferment; till by degrees it gets very strong indeed. The fermentation is then stopped by bunging up the casks; as if it were suffered to ferment too long, it would become vinegar instead of wine. Wine distilled makes the best brandy, but brandy is sometimes made from corn or fruit of different kinds.

The other principal use made of grapes is to turn them into raisins. The best grapes for this purpose are those which have grown on the sunny side of a hill. These are gathered when they are quite ripe, and all the bad and unripe ones are carefully picked out of each bunch. A liquid is then prepared, by pouring hot water on wood ashes, and then letting it run off clear; the water is afterwards poured on other ashes, till it becomes very strong. It is then strained 
off, and boiled; and while it is hot, each bunch is dipped into it separately. Dipping the grapes into this boiling water shrivels them up; and when they are taken out of the water, they are laid upon wooden sieves to drain. When the moisture has drained from them they are laid on other sieves, and exposed to the heat of the sun every day (carefully guarding them from the dew or rain) for about a fortnight, when, if the weather has been fine, they will be quite dry, and ready to be packed in boxes for sale. In some places the grapes are dipped in boiling limewater, and laid on sticks to drain and dry; but the raisins thus prepared are inferior to the first.

The dried currants, as they are called, which are bought of the grocers for putting into plum cakes and plum puddings, are also a kind of grape. The word currant is a corruption of Corinth, as these small grapes were originally brought from that city, though they are now grown in the Ionian Isles, and principally in Zante and Cephalonia. When ripe, they are dried merely by spreading them on the ground, having first cleared it and made it as firm as possible. The currants thus exposed are protected from the dew by reed mats; but they are often seriously injured by heavy rains. When dry, they are 
gathered up and put into bags for sale. It is this habit of laying them on the ground to dry that makes currants so dirty. You know, I suppose, that they are always washed before putting them into a pudding or cake; and indeed I have seen little lumps of earth picked out of a pound of currants, before they were put in the water.

Besides the common grape vine (Vitis vinifera), there are many other species; but I do not think it would interest you to enumerate them. The vine belongs to the natural order Vitaceæ; and there is only one other plant belonging to the same order that I think it necessary to tell you about. This is the Virginian Creeper, or five-leaved Ivy (Ampelopsis Hederacea). It is a very valuable plant in a smoky city like London, for it will grow quite well in the closest situations; and in autumn its leaves turn of so beautiful a crimson, that it looks like a mass of flowers. Mixed with the common ivy, and seen at a little distance, it looks like some new and undescribed plant, with dark green leaves, and bright crimson flowers. It is a native of North America, and was brought to England about two hundred years ago, in the reign of Charles $\mathrm{I}$. 
THE AMERICAN PITCHER PLANT.

One of the most interesting parts of the study of plants is, that it continually brings before us examples of the goodness and power of the Almighty. The plant before us is a native of Carolina, in North America, a country liable to alternate seasons of drought and moisture; and when the dry weather comes, the little birds who had been used for several months to find abundance of water, would be in danger of perishing from thirst, were it not that they find a supply of liquid in the hollow leaves of this plant. The leaves of the Sarracenia purpurea are indeed really pitchers, which hold water, and they are furnished with lids or covers, which are wide open when the weather is moist, but which shrink down in dry weather and prevent the evaporation of the water contained in the leaf below. When the little birds want the water, they raise up the lid with their beaks, and put their little heads into the pitcher. This plant is also called the Side-saddle flower, because part of its flower somewhat resembles a side-saddle. There is another pitcher plant, which comes from China, and which botanists call Nepenthes distillatoria. 
The Evening Primrose Tribe(Onagracea).

I am now going to tell you about the plants belonging to the order Onagraceæ. Ah! I see I no longer frighten you with my hard words, and that you will not be surprised when I tell you that this order contains some very pretty plants, most of which you know very well already.

The first I shall tell you about is the French Willow Herb (Epilobium angustifolia). It is a tall handsome plant, with very pretty pink flowers, which grows wild in England in marshy places, particularly by the side of brooks, and in moist shady places in woods. It has smooth narrow leaves, and looks so much like a willow, that I suppose people could not help calling it the willow herb, though I do not know why they called it French. Its botanic name of epilobium is from two Greek words, signifying a flower upon a seed pod; and this is just the case with the epilobium, and all the flowers of the evening primrose tribe, for the flowers of all of them do grow upon their seed pods. Angustifolium means narrow leaved; so that you see, as I told you once before, a great many of these hard botanic names, when they are 
explained, give a very good idea of the plant they are used for.

There is another kind of French Willow Herb (Epilobium hirsutum), the common name of which is Codlings and Cream, because it smells like that very nice compound. This kind grows in ditches, actually in the water; and it is called hirsutum, which means hairy, because its leaves are quite rough with small hairs.

The evening primrose is another plant belonging to the same order, and there are a very great many different kinds. One of these (Enothera biennis), the Virginian Evening Primrose, grows five or six feet high, and bears pale yellow flowers; and though it was brought originally from Virginia, it is now often found wild in England. It is sometimes called the tree primrose, because its flowers are something like those of the primrose, at least in colour, and it grows so much taller than that plant, that it may be comparatively called a tree; but I do not think the name a good one.

There are some of the kinds of evening primrose which have no stem, but their large white flowers come out of the middle of their leaves. The Tufted Evening Primrose (Enothera cæspitosa) is one of 
this kind. Some of them are tall, and have beautiful pink or lilac flowers; such as the Rosy Evening Primrose (Godetia rubicunda); and others are white, with dark purple and pink spots at the base of each petal.

All the evening primroses are very beautiful flowers, and not only beautiful, but curious. When the calyx that unfolds the bud of all the yellow and white kinds of evening primrose begins to open, it cracks first at the bottom; the points of the sepals remaining firmly hooked together at the top, as though they were determined not to let the flower expand. The flower, however, is equally determined to come out; and, after struggling some time, at last it gets sufficient force to tear the sepals asunder, and to burst forth from bondage. As soon as it has done so, as though enjoying its newly acquired liberty, it spreads its petals out quite flat, making itself as large as it possibly can. Thus it remains all night, but in the morning, at the rising of the sun, it shrinks from the rays which would soon dry up and wither its stamens and pistils, and folds its large petals about them as a cloak, to shield them from the intense heat. Thus you will always find the flowers of the yellow and white evening primroses closed when the sun 
shines brightly; but when the day is cloudy, or at night, they open their petals to their full expanse.

The Clarkia is a pretty flower with curiously shaped petals. It is a native of North America, and was named in honour of Captain Clarke, who discovered it on the Rocky Mountains. The kind that was first brought to England, in 1826, is Clarkia pulchella, with lilac or white flowers; but Clarkia elegans, which is a tall growing plant with rosecoloured flowers, was not brought to England till 1832. They are both annuals, and if you sow the seed in spring, they will come into flower in about a month or six weeks, if the soil be good and the weather fine.

The Fuchsia, as no doubt you know, is a beautiful plant, and the most beautiful of all the fuchsias, as well as the first introduced, is Fuchsia coccinea. This plant was brought from Chili, in 1788, by Captain Firth, who gave it to the director of the Botanic Garden at Kew. I have been told that the Mr. Lee, who then had the Hammersmith nursery, the grandfather or great grandfather of the present Mr. Lee, saw the scarlet fuchsia in flower at Kew, and he admired it so much, that he asked for a sprig of it, that he might try to grow it in his nursery. When 
he had obtained a sprig, he cut it into half as many pieces as there were joints, cutting off each piece clean, and close below a joint, which was put into the ground, and made firm, to induce it to throw out roots, and leaving another joint above ground to throw out leaves and flowers. This is called making cuttings.

When Mr. Lee had made cuttings of his sprig of fuchsia, he put them into his hothouse with a bell glass over each; and there they soon began to throw out roots from the lower joint, and leaves from the upper one, so that he had as many nice young plants as he had made cuttings. As soon as his young plants began to show flowers, he put some of them intc his greenhouse, and the first lady who saw them gave him a guinea for one; then another lady came and gave him a guinea for another; and so on, till he would not sell any more, because he was obliged to save some of his plants to make more cuttings. He did so, and sold them the next year, till at last he had made two or three hundred pounds out of that little sprig of fuchsia; which, if it had been given to any one who did not know the value of it, would only have looked pretty in water for a day or two, and then have been thrown away.

When the scarlet fuchsia was first introduced it 
was thought so tender as to require a hothouse in which a fire was kept night and day; but Mr. Lee found out that it would live in a greenhouse, or in the window of a room; and since his time, it has been planted in the open garden, near London, and found to stand pretty well. Its stem is indeed generally killed down to the ground every winter by the frost; but the root remains alive, and that sends up young shoots in the spring, which sometimes grow six feet high in the course of the summer, and are covered with a profusion of blossoms.

Besides the common fuchsia, there are many other kinds; the most beautiful of which is Fuchsia globosa. The buds of this plant look, before the flower is fully expanded, like the drops of coral ear-rings; and, in the summer, the whole plant is one mass of blossom. It is very hardy, and will live through the winter in the open air very well. Fuchsia virgata is also hardy, and next Fuchsia gracilis. They are both very much like Fuchsia coccinea. The most curious of all the fuchsias, is Fuchsia microphylla, the flowers of which are so very small that it looks like a doll's fuchsia.

These are all the plants that I mean to tell you about that belong to the natural order Onagraceæ; and though the flowers of those I have mentioned are 
very different from each other, they all agree in having the seed pod below the flower, so that when the seed pod begins to swell, it seems to be pushing off the fading flower before it. You will see this very plainly in the Evening Primrose, and in the Clarkia. The seed pod of the fuschia is a kind of berry; and if you will come and see me in autumn, I will show you a sprig of fuchsia coccinea with the ripe berry growing beside the flowers.

\section{QUESTIONS.}

1. What is the meaning of the word Helix, and why is it applied to the Ivy? 2. Of what country is the Common Ivy a native, and where does the plant called the Irish Ivy come from? 3. What are raisins? 4. What are the currants used in plum-pudding, and why do they take that name? 5. What part of the Pitcher plant holds water, and what is the use of it? 6. What is remarkable in the Evening Primrose tribe?

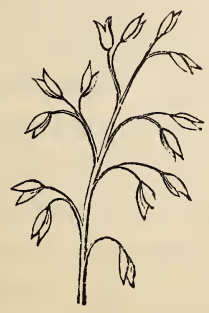




\section{CHAP. VIII.}

THE MYRTLE TRIBE. STORY OF THE FRENCH ABBE. THE VOYAGE TO DIEPPE. THE CLOVE AND OTHER SPICES. THE MYRTACEA OF NEW HOLLAND.

\section{The Myrtle Tribe (Myrtacec).}

THIs tribe of plants comprises most of what are called aromatic plants ; that is, those that are particularly fragrant. You know the common myrtle. Well! all the plants I am going to tell you about to-day, more or less resemble that plant. You have seen the flower of the myrtle I suppose, and if you have, you know that it is comprised of five white petals, and a bunch of long white stamens in the centre, like a tassel of fine threads. The calyx is clove-shaped, and divides at the top into five short sepals that look like a Vandyke edging. Now, the flowers of all the plants belonging to the Myrtle tribe are more or less like this. They have all a clove-shafted calyx terminating in five sepals, and with a long tube below; and they have all flowers which consist principally of a great number of very long stamens. The fruit of 
most of them is a kind of juicy berry which forms in the tube of the calyx, and which in general retains the short vandyke-fringe-like sepals as a kind of crown, even when it is ripe. Some of the plants be longing to the myrtle tribe have dry seed pods; but these dry seed pods form in the same way as the juicy berries in the tube of the calyx, and all the plants belonging to the order, whatever their fruit may be, agree in having tassel-like flowers.

You know that the leaf of the myrtle is fragrant, but probably you do not know the cause. Here is a leaf of the common broad-leaved myrtle; and if you hold it up to the light, you will see that it is full of very small white dots, that look almost like little holes. The midrib of the leaf also looks white and clear, and there is a clear white border all round the margin. These transparent dots and lines are all characteristic of the myrtle tribe; and you will find them in every plant belonging to the order; in some larger than in others, and in some scarcely visible, but the dots, at least, are in all.

You will perhaps be curious to know what these dots are for. Smell the myrtle leaf; now rub it between your fingers and then smell it again. Do you not perceive how much more fragrant it is now 
than it was before? The reason is, that in rubbing the leaf, you broke the thin skin that covered these transparent dots, or rather little cells; for such they were, and each was filled with a fragrant oil, which by bruising the leaf, and so breaking open the cell, you suffered to escape.

\section{THE MYRTLE.}

The common broad-leaved Myrtle (Myrtus communis) is a native of the south of Europe; particularly of the south of France and Italy. The narrow leaved myrtle is a native of Greece. There are several varieties of these which differ principally in the shape of the leaves. The ancients dedicated the myrtle to Venus, as being one of the sweetest of plants. The Greeks, who were fond of making fables out of every thing, said that the myrtle was once a nymph named Myrsine, who was a great favourite with Minerva. Myrsine, however, happened to fall in love; and Minerva, when she heard of it, was in such a passion that she changed poor Myrsine into a myrtle. This was not very consistent with the character of the goddess of wisdom, but the Greeks made their gods and goddesses do strange things. So poor Myrsine became a myrtle, and Venus, who was the goddess 
of love, when she heard of her misfortune, declared that the myrtle should thenceforward be dedicated to her.

Myrtles, being natives of a warm climate, are generally kept in England in greenhouses or rooms; but it is a fact, that some of the first myrtles brought to Great Britain were planted in the open air, and lived there to be large trees. The myrtle was introduced into England by Sir Walter Raleigh. This great man, when he was young, passed several years in the south of France; and while there, being very fond of plants, he was much delighted with the myrtle. He had a friend in England, Sir George Carew, whom he knew to be as fond of plants as himself; so Sir Walter brought home a myrtle for his friend, and it was planted on the lawn at Sir George's house at Bedington near Croydon.

Many years afterwards, in 1589, Sir Walter Raleigh visited an estate that he had in Ireland, at Youghal near Cork, and his friend gave him some young myrtles which had been raised from the old tree, and which Sir Walter planted at Youghal. This visit to Ireland was a very interesting one ; for Spenser the poet, who lived near, used to come and walk with Sir Walter in his garden, and read to him the first 
three cantos (all that were then written) of the Fairy Queen. Sir Walter was delighted with the poetry, and it was he who brought the poet to court, and presented him to Queen Elizabeth.

But I am forgetting the myrtles. The one at Bedington lived there without any protection till the year 1739, when there was a very severe frost which killed it. It is rather curious that the very severe frost which we had lately, that killed so many trees, was in 1838, very nearly a century after the severe frost that killed the Bedington myrtle. The myrtles planted by Sir Walter at Youghal are still living; and when they were measured three or four years ago, the largest was about twenty feet high.

THE STORY OF THE FRENCH ABBÉ.

Talking of myrtles reminds me of an adventure that happened some years ago to my friend Mr Douglas, whom you have often heard me talk about. Mr. Douglas was dining with a party of friends at Brighton, and after dinner, when they were all in spirits, one of them proposed to take a trip over to France. This was no sooner thought of than executed. They were all delighted at the thought of seeing France, a packet boat was just going to sail ; 
they hastened on board, and as the weather was beautiful, they enjoyed their voyage very much. They remained on deck as long as it was light, and when night came on, and it grew dark and cold, they retired to their cabins; and when they woke the next morning they found themselves within sight of the French coast.

It is not quite so easy to travel in France as in England. The moment you land on the French shore you are asked for your passport, which is a piece of stamped paper, with your name and a description of your person written on it, and signed by the French ambassador, or some person appointed for that purpose, in England. When you arrive in France, at every town you enter you must show your passport, and you must have it signed by the mayor of the place before you can leave one town to go to another. Mr. Douglas and his fellow travellers never thought of this. All they thought of was, how much they should like to visit France; and they were quite startled when they found themselves seized by the gend'armes on their landing, when it was found that they had no passports.

The soldiers would not listen to a word that the poor travellers had to say. "They are spies!" cried 
the soldiers. “ They are spies!" echoed the people; and Mr. Douglas and his companions were just on the point of being dragged to prison, when an old French abbé interposed and addressed the people.

He was an old man with a most benevolent countenance, and long white hair; and when he spoke, his voice was so mild and persuasive, that all the shouts and cries were hushed, and the people stood silent, listening to him. "My friends," said he, " these are strangers and Englishmen. I have been a stranger in England, and I met with such kindness from the people there, that I feel as though every Englishman were my friend. They are strangers who cannot mean to act as spies, for they can scarcely speak our language. They have come merely to see our fine country, and I am ashamed that they should have reason to form so bad an opinion of the inhabitants of it."

The people seemed ashamed of their violence, and the mayor of the town having come out among them on hearing the tumult, promised that the Englishmen should not be sent to prison; on condition that the old abbé would take charge of them, and not suffer them to quit his house, till they were ready to reembark for their own country. 
This was done; the good abbe took them to his house, and treated them with the greatest kindness. He showed them his garden; and he spoke of plants as one who loved them, and who had studied their structure and uses. He was indeed a man who had read much, and mixed but little with the world. He had met with troubles, but the goodness and simplicity of his character had prevented them from injuring either his heart or his temper. The English travellers were delighted with him, and after spending a most agreeable evening, they retired for the night.

The following morning at five o'clock the abbé roused his guests and conducted them to the shore, shaking hands heartily with them, and wishing them health and happiness. Before the travellers reembarked, they asked their kind preserver what they could do for him. At first he would not hear of anything; but when he found it gave them pain not to be able to do something to show their gratitude, at last he asked them if they would send him a myrtle from England. "I have seen such beautiful myrtles in pots in England," said he, "that I have often wished to have one."

They promised to comply with his modest request; but I know not how it was, the promise, the myrtle, 
and the French voyage were all entirely forgotten. The party did not meet again ; and the busy affairs of life fully occupied the attention of all. "Some years afterwards," said my friend Mr. Douglas, when he was relating this story to me, "being again at Brighton, my singular adventure and our promise were recalled to my memory; I went by the coach to Tooting in Surrey, and bought of Mr. Rollisson one of his finest myrtles, and carried it to France: but on coming to my venerable friend's residence, I had the sorrowful mortification to find that our kind, good, and pious host had ceased to exist. $\mathrm{He}$ had died the previous day. I told my former adventure to his relatives, and I saw the myrtle planted at the head of his grave, where it now flourishes, and is the pride of all who go there to offer up their devotions by the tomb of their former beloved pastor. It may be seen full of its beautiful blossoms every year in the month of August; and its history is now related by many a villager, who remembers with pleasure the good old priest, and also the relator of this simple but true narrative."

I was very much interested in this tale, and very sorry that the poor old abbé did not live to know that Mr. Douglas had brought him the myrtle. 
"Your adventure had a melancholy ending," said I. "Yes," returned he, " and a most melancholy event happened on my second voyage." I begged him to tell me what that was; and accordingly he related the circumstance in the following words:

\section{THE VOYAGE TO DIEPPE.}

" ' Let no man hereafter say, This shall be a day of happiness.' The truth of this observation I can illustrate by the following narrative: the occurrences are of a melancholy nature, and took place on my voyage from Brighton to Dieppe with the myrtle I had promised the good old priest. One of the first things I did after I was on board was to look for my favourite plant; I soon found it in the hatchway of the cabin: round about it I saw a group of happy faces consisting of (as I afterwards learned) the father, and mother, and their four children. The lady was a fine and beautiful figure, her countenance full of life and animation, her bright eyes sparkling with pleasure. She seemed as if she thought the education of her children was the greatest, the best, the highest, the holiest vocation that could possibly devolve on her as a parent. She was telling her children the history of the myrtle plant, and well 
I remember her observations; they were made in a plain and perspicuous style suited to rivet the attention of both old and young; and she gave her descriptions in a manner that at once displayed her knowledge of botany, and good sound sense on many other subjects incidentally mentioned. I introduced myself as the owner of the myrtle, I related the anecdote of my former visit to France to her children; in fact, I soon became a favourite with this happy family. I soon learned that they had a temporary residence at Brighton, and being desirous of seeing the coast of France, had taken advantage of the steam vessel going to Dieppe, intending to return with the vessel on the third day. While we were enjoying each other's company in conversation, which for the sake of the children partook of instruction and amusement, she occasionally called their attention to the works of the Almighty as seen in the wonders of the ocean, reminding them of that gratitude all creatures owe to God for the blessings they receive, and that daily in our walks and drives we see the hand of providence in all created things round about us; even the poor Indian with ' untutored mind sees God in clouds and hears him in the wind.' While we were in this scene of happiness, the report of a 
signal gun shook the vessel ; a signal of distress was also hoisted at the mast head: a dreadful fear came over all, each inquiring, but no one able to answer, what was the cause of these signals? Although much alarmed I did not lose my presence of mind; I spoke kindly to the lady, hoping to inspire her with confidence; I urged her to keep up her spirits, to rely on that being for protection whose name was in her mouth only a few minutes before, leading her children on 'from nature up to Nature's God;' but all my efforts were in vain, stupor gradually came over her, she sunk on my breast, she breathed with difficulty, a cold sweat came over her, fear had totally deprived her of reason, her pulse gradually sunk until it was scarcely perceptible: we carried her down into the cabin. We now saw boats coming off from the French coast to our assistance, and by the time she was laid down in a berth the boatmen had taken us in tow: I went down into the cabin, I told our invalid this good news. Without opening her eyes I could perceive that she understood me; a sweet smile came over her countenance, such as is occasionally seen on the face of a sleeping infant, she gave a heavy sigh, and resigned her soul into the hands of her Maker. It would be impossible to describe the 
scene that followed this melancholy event. There was on every side a deep sorrow, there was scarcely a dry eye on board ; but what was the grief of others to the heart-rending sufferings of the widower and his four children; only two short hours had elapsed since all on board were enjoying the highly cultivated and intellectual conversation of this accomplished woman, who was now lying before us a corpse. We got safely on shore; the body of our late lamented fellow traveller was next day committed to the dust; hundreds of the inhabitants who had heard the sorrowful tale followed her to the grave. I witnessed the heart-rending scene, and afterwards saw the husband, the four children, and the two female servants set off on their journey; they were enabled to proceed slowly overland towards Calais intending to cross the channel to Dover, on their way towards London, after enduring trials such as seldom fall to the lot of men."

This is a melancholy tale, and had you heard Mr. Douglas tell it. as I did, you would have been still more powerfully affected; I have given you his words, but I cannot give you his voice and manner. But we must not dwell on such gloomy subjects. We must return to our trees, for I have many others 
belonging to this tribe to tell you of, some of which, I think you will find interesting.

\section{THE CLOVE TREE.}

Do you know the name of those little brown spices which are put into apple pies, and among stewed pears, to improve their flavour? They are called cloves, from the French word clou, a nail, because their shape somewhat resembles that of a nail. Do you know what they are? If you do not, I will tell you. They grow on a tree, and you will be surprised to hear that they are not the fruit but only the dried flower buds!

Here are some cloves. Now let us examine them. You see their shape is, as I told you, like that of a nail, with a little round knob for a head. This little knob is the flower bud, as I will show you by opening it with a pin. First a scale comes off and then another, and another. These are the dried petals of the flower. Now let us see what lies beneath them. It is so dry that it crumbles between my fingers; but you may still easily see that it has been a bundle of stamens. This is the case, for the clove tree belongs to the natural order Myrtaceæ, and its flowers are very much like that of the myrtle, 
except that the bunch of stamens in their centre is of a bright yellow, instead of being white.

The lower part of the clove is the calyx, and the four points of the sepals, which form a kind of cup round the flower bud, will remain like a crown on the fruit, when its germ which is now hidden by the tube of the calyx, has swelled into a long dark purple berry. The leaves of the tree are broad, thick, and shining, like those of the broad-leaved myrtle; and the tree itself is generally about twenty feet high.

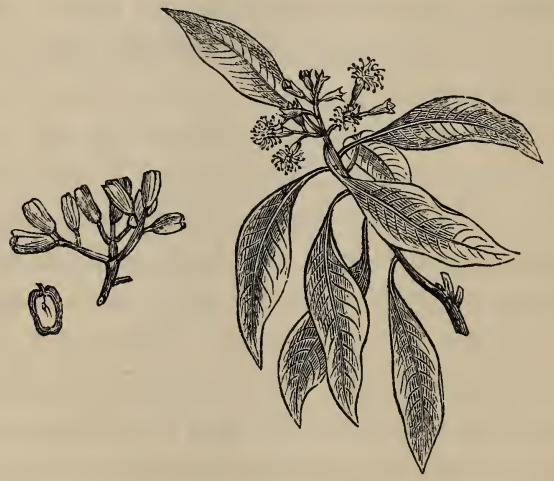

FRUIT, AND FLOWER OF THE CLOVE TREE.

The Clove tree (Caryophyllus aromaticus) is a native of the Molucca Islands; and it is cultivated 
in nearly every part of the East and West Indies. It is very long lived, and it bears such a quantity of cloves, that I wonder how they are all consumed. One tree will produce sixty pounds weight every year. When they are gathered, the negroes first spread cloths on the ground; then they climb up the trees, and pulling off all the flower buds they can reach, they let them drop on the cloths; and lastly, as there are some buds which they cannot reach with their hands, they get soft reeds, and gently knock them off the branches. When all the buds are gathered, the cloths are carried away and laid in the sun, till the cloves are dry enough to be packed up for sale.

\section{ALLSPICE.}

The Allspice, which is sometimes also called Pimenta, and Jamaica pepper, is gathered in the same manner as the clove; but the spice is the fruit, and not the flower bud, of the tree on which it grows.

The tree (Eugenia pimenta) was formerly called Myrtus Pimenta. It is evergreen and resembles that of the clove in size and general appearance, but the flowers are much smaller and not so handsome. 
The berries, when they are to be used as spice, are gathered while they are green. They are first spread out on wooden trays, and placed to dry in the sun; and afterwards they are put into large linen cloths, which four negroes hold at the four corners, and shake up and down to free the berries from the crown-like calyx, which adheres to them, as a similar one does to the fruit of the clove. It is a droll sight to see the negroes shaking the cloths up and down, while the dry berries rattle as they roll them to and fro; but though it looks like play, it is hard work for the negroes under the burning sun of Jamaica, where this spice is principally grown. One tree has been known to bear a hundred and fifty pounds of fruit, which when dry has made a hundred pounds of allspice.

\section{THE GUAVA.}

Have you ever tasted Guava jelly? If you have, you will be interested to hear that it is made from a yellowish pear-shaped berry called the Guava. The tree (Psidium pyriferum) which bears it is a native of the West Indies; but there are two other kinds of guava, one (Psidium pommiferum) a native of the East Indies, the fruit of which is not very good; and 
the other (Psidium Cattleyamum), a native of China. This Chinese guava is much hardier than the other kinds; for while they require a hothouse, to enable them to live in England, it has been known to ripen its fruit in this country against a wall in the open air. The fruit, like that of all the Myrtaceæ, is a kind of berry; and it looks very much like an Orleans plum; but when eaten, it has a little of the flavour of a strawberry.

THE CAJEPUT TREE.

The Cajeput tree is a native of the East Indies, where it is called Caju-puti by the natives. It has a black trunk and white branches, for which reason botanists call it Melaleuca leucodendron, which means the black and white tree. The leaves are long and narrow; and the flowers are white and tassel-like. You may easily imagine how curious the black trunk looks peeping through the white branches; particularly when the tree has grown to its full size of eighteen feet or twenty feet.

The cajeput oil is distilled from the leaves. This oil has a very strong sharp smell, like a mixture of hartshorn and turpentine; but when taken it tastes like peppermint. It is given as a medicine; and it is 
used by people who have the rheumatism to rub themselves with, to ease their pain. I often find it ease me, when my old limbs ache with a change of weather. This oil is clear, and of a beautiful green colour; and it is one of the few substances in which Indian rubber can be dissolved. The Chinese use the bark of this tree for covering their houses.

\section{THE MYRTACEA OF NEW HOLLAND.}

The trees of Australia are as different from those of Europe, as the kangaroo is from the European animals. There is always something peculiar in their foliage and general appearance, or in their flowers and fruit; and no trees are more remarkable in all these points than those belonging to the genus Eucalyptus. These trees are all enormously tall, so tall indeed that I shall hardly be able to give you an idea of their size. They are called Gum trees in the colony, because they produce a kind of gum which is used in medicine. There are many different kinds of eucalyptus, but they have all the same peculiar bluishgreen foliage; and they are so abundant in Van Diemen's Land and New Holland, as to cover the whole face of the country, and almost to hide all the other kinds of trees. 
The largest trees of the genus Eucalyptus are those called Stringy Bark Trees in Australia, but their botanical name is Eucalyptus robusta. The leaves are oval, of a bluish green, and the same on both sides; as they hang so as to have both sides equally exposed to the sun. The flowers consist of tufts of stamens without any petals, which look as though just bursting out of a little cup. This tree grows generally above two hundred feet high, and it has been known to have a trunk measuring sixty feet round. You can hardly form an idea of the size of these enormous trees; for you have none like them in England. But if you can imagine two of the highest trees in Kensington Gardens set one upon the other, then the tree they would form would be about the size of the smallest full-grown eucalyptus in its native country. The trees on each side of the broad walk in Kensington Gardens are generally not above sixty feet high, so that it would take three of these, set one upon another, to make two hundred feet; and yet a friend of mine living in Van Diemen's Land, measured ten of the eucalyptus trees growing in a wood there, and found not one of them less than two hundred feet high, and one was two hundred and thirteen feet! The largest of these trees was fifty- 
five feet round, and the smallest thirty-five feet; so that if the largest tree had been hollowed out, it would have made a very comfortable room. Hollow gum trees are indeed often used by travellers in the wild parts of Van Diemen's Land, as places of shelter during the night; and Frazer found a hollow eucalyptus at Moreton Bay, which was used by the natives as a burying place.

The Iron Bark Tree (Eucalyptus resinifera), called sometimes the Red Gum Tree, and sometimes the Kino Gum, by the Australians, is also an enormous tree. Here is one with a man standing beside it, to show how much bigger the tree is than a man six feet high. Does it not appear

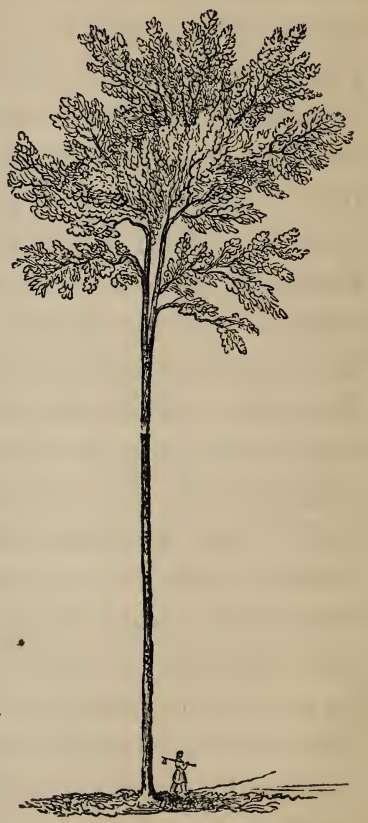
EUCALYPTUS, OR IRON BARK TREF, TWO HUNDRED FEET HIGH. presumption in a little creature like that, to attempt 
to cut down an object so immeasurably above him? Yet he did so, and with that little axe over his shoulder. How is this accomplished? By the power of mind over matter. When the Divine Creator breathed His own spirit into man, He gave him power over all creation. The horse, the bull, and even lions and tigers, great as is their strength, have been tamed by man; by the power of mind prevailing over mere brutal force. In proportion as we cultivate our minds, we increase the power that God has bestowed upon us; and in proportion as we neglect their cultivation, we sink down to the level of those brutes, above which His mercy has enabled us to raise ourselves.

When the tree of Eucalyptus resinifera has attained its full size its bark becomes very hard and strong; and hence its name of Iron Bark. It is a difficult task for the woodcutters to penetrate through this bark ; but when once it is passed, the wood is found soft, till after it has been sawed up and exposed to the air, when it becomes as hard as oak. When the trees are cut down, large cavities are often found between the circles of the wood, filled with a most beautiful red liquid gum which flows out and follows the saw. This is the red gum, but it is also called 
gum kino by the Australians; though the real gum kino is produced by the red sanders wood of India.

The Peppermint, or Blue Gum Tree (Eucalyptus piperita), has the singular property of throwing off its bark, which is very thin, in long strips or ribbands, which have a silky and bluish hue, and produce a striking effect as they glitter in the sun, and wave to and fro in the wind. The stump of this tree has the property of remaining sound a great many years after the tree is cut down. Dr. Laing found one, the trunk of which had been cut down thirtyfive years before, which did not show the least symptoms of decay.

The Powdery Eucalyptus(Eucalyptus pulverulenta), which is sometimes called the White Gum Tree in Australia, is one of the hardiest of the genus. It has nearly round leaves, which are covered with a powdery whitish bloom. The flower bud is a kind of box, the lid of which gradually opens when the flower is about to expand, and lets out a few of the sta-

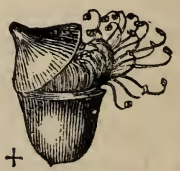

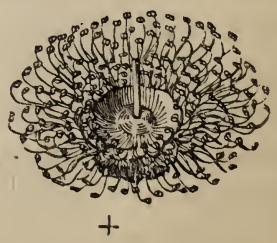

EUCALYPTUS FLOWER. 
mens, which seem struggling to get free. See, here is the calyx just opening, and a flower of the plant beside it, to show you the curious shape of the stamens. All the plants belonging to the genus eucalyptus have this curious box-like calyx; and indeed the name of eucalyptus is taken from two Greek words, which signify to cover with a lid.

There are many other kinds of eucalyptus: one called the Manna Tree, which drops a fragrant kind of gum, in pieces sometimes as big as an almond, and sometimes quite small, like crumbs of bread; and another called the Black Gum : but I think I have told you quite enough of this genus, as I have many many other genera to tell you about.

When the first colonists arrived in New Holland, they gave to many of the trees names which they had been used to in England; and among these, they called many kinds the tea tree. As these are very different from each other, and none of them in the least like the real tea tree, I suppose that the first settlers in New Holland, when they went there, missed their tea very much, and so they tasted the leaves of a great many different kinds of plants, to see which of them was most like the real tea. Had they done this in many countries, they would cer- 
tainly have been poisoned; but luckily for them, there are scarcely any poisonous plants in New Holland. At last they found out Melaleuca linariifolia, the Tea Tree of New Holland: a handsome tree, with long narrow leaves, and abundance of flowers, which look like a great number of tassels of fine green silk. The leaves of many. other plants were also used for tea, and among others those of the Scarlet Melaleuca (Tristania nereifolia), which might be called the Bottle Brush Tree,

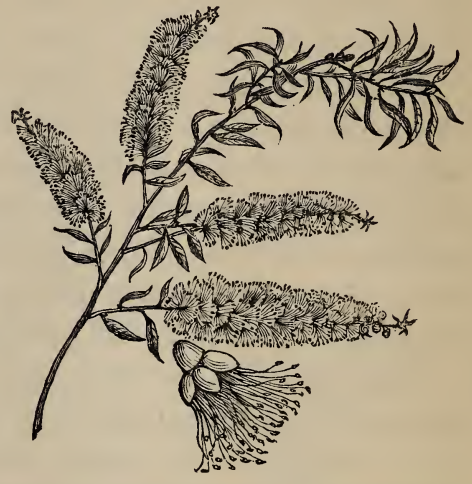
from the shape of its SCarlet Melaledca, or bottle brush tReE. flowers. Here is a sprig of them.

I have now explained to you, as well as I can, why the first settlers in New Holland called some of the trees they found there the tea tree; but I am sure I do not know why they called the Angophora lanceolata, the Apple Tree, for the fruit, like that of all the Myrtaceæ, is a berry instead of an apple. 
What they call an oak is a tree with long narrow leaves like grass; their chestnut tree bears pods like a bean plant; what they call a myrtle is a beech. You laugh at these strange names, but they make me melancholy whenever I think of them. The first settlers in New Holland were in a foreign country, where every thing was new and strange to them. The very stars were different from those they had been used to see; the animals were of strange and what appeared to them unnatural forms; and the trees were all different from any that they had ever seen before. What wonder, then, that the poor emigrants were delighted to trace even fancied resemblances to forms that had been once familiar to their eyes, and that they delighted to call these new objects by names which reminded them of home.

\section{QUESTIONS.}

1. What are the characteristics of the Myrtle tribe? 2. What part of the Clove Tree is the clove? 3. Where does the Allspice Tree grow? 4. What is the height of some kinds of Eucalyptus? 5. What country is the Eucalyptus a native of? 


\section{CHAP. IX.}

POMEGRANATE. BRAZIL NUTS. GARDEN SYRINGA. THE WITCH HAZEL. DOGWOOD. THE AUCUBA, OR JAPAN LAUREL. MISLETOE. SUPERSTITIONS RESPECTING THIS PLANT. CUCUMBER TRIBE. INDIAN FIG TRIBE. COCHINEAL INSECT. FIG MARIGOLD TRIBE. ICE PLANT. CAPER PLANT. MIGNIONETTE, HEARTSEASE, AND VIOLET.

THE POMEGRANATE.

Many botanists class the Pomegranate with the myrtaceæ, but others make it form an order in itself, which they call Granataceæ. It has bright scarlet flowers, and a fruit something like an orange, but even when ripe, retaining the points of the calyx like a crown. It was this worthless crown which made Ann of Austria, when she was queen regent of France, choose a

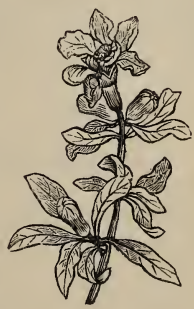

FLOWER.

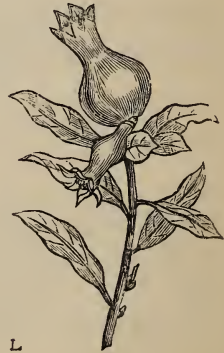

FRUIT. 
pomegranate for her seal, with the motto, "My worth is not in my crown." The pomegranate is a native of the East, and we read of it often in the Bible; but it also grows in the south of France, and it is so abundant in Spain, particularly near Grenada, that the city is said to take its name from the fruit.

\section{BRAZIL NUTS.}

These nuts are the fruit of a tree called Bertholletia excelsa, which grows about one hundred feet high in the forests on the banks of the Oronoko; and yet not growing thicker than two feet in diameter, and not sending out any branches till near the top, when its boughs hang down in rather a graceful manner; though the whole plant gives the idea of an umbrella fixed at the top of an amazingly long stick. The flowers somewhat resemble those of the myrtle; they are of a yellowish white, and have a great number of stamens in the centre, joined into a thick fleshy ring. The fruit is round, and as big as a man's head. It is divided into four cells, each containing six or eight nuts. The leaves are very large, being generally two feet long, and about six inches wide; and they differ from those of the plants belonging to the myrtaceæ, in being entirely without transparent 
dots. The tree is a native of Brazil, and has never been introduced into England. It belongs to the natural order Lecythidex, and was named in honour of the distinguished French chymist Berthollet.

\section{THE GARDEN SYRINGA.}

The flowers of this plant (Philadelphus coronarius) smell so much like those of the orange, that it has been called the mock orange; but its leaves taste like cucumber. It is common all over Europe; and there are many kinds which are natives of North America. It belongs to the natural order Philadelphaceæ.

\section{THE WITCH HAZEL.}

Many many years ago, when North America was an English colony, the inhabitants of New England were great believers in witches. If the cream they were churning did not turn into butter quite as soon as they wished, if their hens laid away, or if their cows did not give a proper quantity of milk, it was all laid to the witches. In England, they had been used to fancy the witch or Scotch elm to possess the power of driving them away; but unfortunately the Scotch elm does not grow in North America, so they were forced to look out for some other tree, which, as you 
may easily suppose, did just as well, since the whole charm lay in their own credulity.

In North America there is a little shrub, which, in winter, when all other deciduous plants look bare and desolate, is covered with a profusion of rich yellow flowers, though it has lost all its leaves. This peculiarity struck the New Englanders, and made them fix on this shrub to use as a charm against witchcraft; and as its leaves somewhat resembled those of the hazel, they called it the witch hazel. Its botanic name is Hamamelis virginica, and it belongs to the natural order Hamamelaceæ.

THE CORNEL, OR DOGWOOD TREE.

The common or Red Dogwood (Cornus sanguinea) is a native of Britain, and it takes its name from the beautiful scarlet which its leaves assume in autumn. Its wood is used for making skewers. It has white flowers, and its berries, which are purple, are too bitter to be eaten. The White Cornel (Cornus alba) has white fruit and red shoots, which are very conspicuous in winter in the shrubberies. The name this species bears among the Cree Indians is Musquamena-meethquan-peemeenattick-meenisan! There! try to pronounce that if you can! 
The Cornelian Cherry Tree (Cornus mascula) has yellow flowers, and beautiful red coral-like fruit, which makes a nice sweet-meat. This species is very common in Germany, and in the garden of the ancient chateau of Maskirch, in Bavaria, there is a labyrinth, the hedges of which are formed of cornelian cherry trees clipped close, except at the corners, where a few plants are allowed to shoot up as trees. The handsomest of all the kinds is, however, Cornus florida, or the Virginian Dogwood. This fine tree is a native of North America, and its large white flowers make it look, in summer, as if covered with a white sheet. The Virginian dogwood trees grow in groves in America, and from their spreading branches and large leaves, they form an intense shade; and the dogwoods, as they are called, are most delightful retreats from the burning heat of the sun. The fruit, which is of a bright scarlet, is produced in bunches like the berries of the mountain ash, and the birds are very fond of it. The Virginian dogwood was first brought to England in 1731.

THE AUCUBA.

One of the most valuable shrubs in English gardens is the Aucuba Japonica, sometimes called the 
Japan or Spotted Laurel. This tree, though a native of Japan, will stand the severest frosts without protection; as was proved by its living through the severe winter of $1837-8$, when the common laurels growing near it were killed. The aucuba retains its leaves all the winter, and in England they are always mottled with yellow. It has never produced fruit in this country, but in Japan it bears red berries. When it was first brought to England, which was only about fifty years ago, it was placed in the hothouse, then it was ventured into the greenhouse, and then planted in the open air, where, as I before observed, it is found to be more hardy than the common laurel. The different kinds of dogwood, and the aucuba japonica, belong to the order Cornaceæ.

THE MISLETOE.

The common Misletoe (Viscum album) does not grow upon the ground, but it is what is called a parasite; that is, it grows upon the branches of trees, and sends its roots down into the wood for support. In England, it grows generally on the apple tree, and very rarely on the oak; but on the continent it is found frequently on that tree. You have heard of the Druids, who were the priests of the ancient Britons. 
Well, these Druids had a great respect for the misletoe, particularly that which grew upon the oak; and, as it was rare upon that tree, when it was found, the Druids went in procession, clad in long white linen robes, to cut the misletoe. They had all long

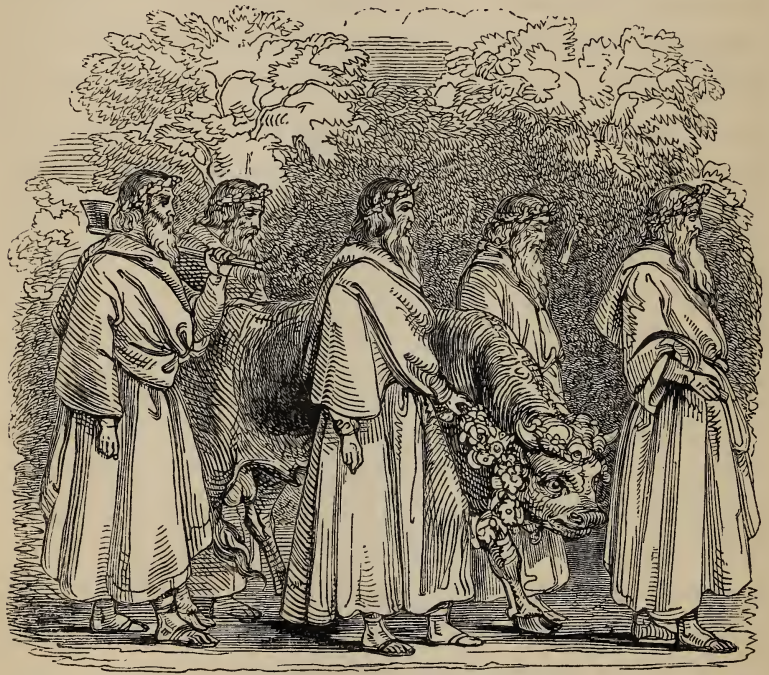

beards, and walked with their feet and arms bare, except that they wore gold bracelets on the latter. They had also gold chains round their necks, and 
the chief Druid carried in his hand a golden knife, shaped like a reaping hook.

Thus attired, the Druids proceeded to the oak, which bore the misletoe, the chief Druid going first alone, and the others following him, walking two and two, and chanting hymns. Between two of the inferior Druids was led a white bull, its horns decked with holly, and a gold chain round its neck, by which the Druids led it ; and at a little distance followed another white bull, led by Druids in the same manner; and after all the Druids came a great number of the people. When they arrived at the tree, the two bulls were tied to it, and amidst their roaring, the exclamations of the people, and the chanting of the inferior priests, the head Druid ascended a kind of ladder, held for him against the tree. When he was sufficiently high to reach the misletoe, he cut it off with his golden knife, and received it into his white linen robe. The shouts of the people and hymns of the Druids were then changed into cries of joy; and as soon as the chief Druid had descended from the tree, the two bulls were sacrificed, and burnt on an altar of stones.

The misletoe was always cut by the Druids on the sixth day of the first moon of their new year, which 
was about our Christmas; and if by any chance none could be found growing on an oak about that time, or if the chief Druid happened to let the misletoe fall after he had gathered it, the shouts of the multitude were changed into cries and lamentations, and it was considered a token of some great national misfortune.

The Saxons also revered the misletoe; and the following curious legend is related in the Edda (which is the book teaching their religion) respecting it. Friga, who was the Saxon goddess of love, made every animal, bird, and fish, and every thing that grew in the earth, or in the water, take an oath not to hurt her son Balder, the Saxon Apollo. Loke, the evil spirit, who wished to injure Balder, took the misletoe, which neither grew in earth nor water, and with it Balder was slain. All nature was instantly overwhelmed with grief for the loss of the god of the sun; and at length Thor, who was the Jupiter of the Saxons, restored Balder to life, and placed the misletoe under the sole controul of Friga, that it might never injure her again. It was from the misletoe being thus dedicated to the Saxon goddess of love, that it is hung up at Christmas in farm houses, for people to kiss under it. 


\section{The Cucumber Tribe (Cucurbitacea).}

You will be surprised to hear that it is not known with certainty of what country the common cucumber is a native. Some persons suppose it to have been found in Tartary, but no modern traveller has ever seen it there growing wild. It is evidently a native of a hot country, and probably grows naturally in woods; as it likes a hot, moist, shady situation. In England, the cucumber is generally cultivated in hotbeds; and when properly watered and shaded, it becomes long, and of a very dark bluish green, with few seeds, and very fine crisp flesh. When grown in the open border, as it sometimes is in summer, the cucumber is short and thick, of a pale greenish yellow, with flabby flesh, and a great abundance of seeds.

The Cucumber plant (Cucumis sativus) is a tender annual, and has been in cultivation since the time of the captivity of the Israelites in Egypt, as we find it mentioned by Moses. In England it is said to have been first introduced about three hundred years ago. It is now grown to a great size in this country, having frequently been known to be two and a quarter feet long. The small cucumbers that are used for 
pickling, are grown in fields, principally in Hertfordshire and Bedfordshire; and are sent up to London in great quantities.

The flowers of the cucumber plant are yellow, and somewhat in the shape of those of a convolvulus; and the leaves are large, thick, and downy. The seeds are flat and oval; and the plant, which is a climber, may be either trained over a bed, by pegging it down occasionally with forked sticks, or nailed up against a wall. I have seen a cucumber plant trained up along the rafters of a greenhouse in this manner, and the cucumbers hanging down among the grapes: and though they were not very good to eat, they looked curious, and rather pretty.

I do not know whether you have ever heard of a medicine which is vulgarly called Pill o' Cocia, but which the doctors name Extract of Colocynth. This substance is the dried pulp of a kind of cucumber, called the Bitter Apple (Cucumis Colocynthis). It is found wild in the Grecian Islands, in Egypt, and throughout the north coast of Africa. The plant grows like that of the cucumber, but the leaves are thickly covered below with white hairs, and the fruit is small, round, smooth, and of a deep yellow. It is hard on the outside, but within the rind, is a white 
spongy pulp, the taste of which is intensely bitter. The fruit is gathered in autumn, just as it is beginning to turn yellow ; it is then peeled; the seeds are taken out, and the pulp is dried rapidly in stoves. This dry pulp is the proper colocynth, but an inferior kind is made by grinding the seeds, and dry rind. When brought to England the druggists powder it, and make it into a paste with honey, and some kind of gum.

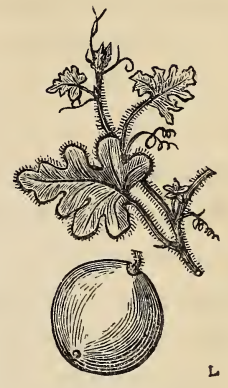

BITTER APPLE.

\section{THE MELON.}

The native country of this well known plant, like that of the cucumber, is unknown; for though Linnæus says that it is a native of Tartary, it has never been found by modern botanists wild in that country. It has been cultivated from time immemorial in Persia, and many of our best kinds come from that country. Very fine melons also come from Cashmere. There are a great many kinds of melon; some with green flesh, which are considered the most delicate; others with red flesh, and a rough rind, which looks 
as though it was covered with net work; and others which have the rind perfectly smooth.

In England, melons are generally grown on hotbeds with glass sashes over them ; but in France, they are sown in the open air like gourds. The most curious ways of cultivating them, however, are those practised in Cashmere and Persia. In Persia, the gardeners throw up ridges like our gardeners do for celery, and fill the ditches between the ridges with water. They then sow the melon seeds on the top of the ridges, and let the plants grow, till their roots come down into the water. In Cashmere, the melon growers get two or three hurdles and tie them together. Then they cover the hurdles with grass and weeds, and let them float on the surface of the water; and as soon as the grass and weeds begin to decay, so as to form a kind of soil, they sow cucumber and melon seeds in it. These are the floating gardens of the lakes of Cashmere; and there are similar gardens, which are called chimpas, in Mexico. The Water Melon (Cucumis citrullus) has deeply cut leaves and round fruit with a spotted rind, pinkish flesh, and black seeds. It has very little flavour, but its coolness, and the abundance of its juice, make 
it agreeable in the hot countries, where it is generally cultivated. There are many other kinds of melon, which it would take me too long to enumerate.

\section{GOURDS AND PUMPKINS.}

These are very numerous; but the most common are the Vegetable Marrow (Cucurbita ovifera), the Mammoth Gourd (Cucurbita maxima), and the Butter Squash Pumpkin (Cucurbita melopepo); all of which, and their numerous varieties, are excellent food. The Bottle Gourd (Lagenaria vulgaris), on the contrary, is a violent purgative and emetic; and though when the pulp is entirely removed, it makes a good bottle, if any of the pulp be left, it is dangerous. In 1837, a soldier was poisoned at Falmouth by drinking beer out of a bottle gourd that was not properly prepared. The Squirting Cucumber (Momordica elaterium) is so called because when its seed pod is ripe, and any one attempts to gather it, the pod bursts, and scatters the seeds with the moisture in which they are contained; and the Snake Cucumber (Momordica cylindrica) derives its name from its long slender fruit, which are often many feet long, and curl and wind about like a snake. 


\section{The Indian Fig Tribe (Cactacece).}

Nothing can be more remarkable than the appearance of the plants belonging to this order. They have no leaves ; or rather, there is no apparent difference between their leaves and their stems. Their flowers, which are generally large and very handsome, grow out of the stems without any foot stalk, and their fruit, which resembles a gooseberry, is eatable. They are all what is called succulent plants, that is, their stems are full of moisture, and easily bruised, and they are all, or nearly so, natives of the tropical regions of America. It is a wonderful provision of the allwise Creator that those plants which grow on hot dry rocks, or sandy plains, where no water can be procured, have their stems filled with abundance of wholesome fluid, and bear a fruit as juicy and refreshing as the European gooseberry.

One of the most beautiful plants belonging to this family is the Crimson Torch Thistle (Cereus speciosissimus). The stem of this plant is thick and upright, it is angular and nearly square, with small protuberances at regular distances, each of which is surmounted by a little bunch of spines. The flowers 
are large and of a most brilliant crimson; and the fruit is a dark purple berry, about the size of a pigeon's egg.

The Creeping Cereus (Cereus flagelliformis) has beautiful pink flowers. This species is a native of Peru, and it is curious for its shoots, which hang down like long cats' tails over the sides of the flower pot, in which the plant grows, and form a striking contrast to the upright majestic stems of the Cereus speciosissimus.

There are many other kinds, some of which have leaf-like stems, such as the Epiphyllum truncatum; others, such as the Melon Thistles (Melocacti), the Hedgehog Thistles (Mammellariæ), and the Porcupine Thistles (Echinocacti) are short and very thick ; some, like Cereus senilis, the Old Man's Head, are long and covered with long gray hairs; and some, like the Melocactus communis, are round like a melon, with ribbed sides, and a kind of woolly cap at the top. The Night-blowing Cereus (Cereus grandiflorus) only flowers in the middle of the night. About eight or nine o'clock, the buds begin slowly to expand, by midnight the flowers are in all their splendour, and before daybreak they have faded, and hang down, the withered wreck of their former beauty. 
These flowers are very large, of a beautitul wax like texture, and white with a yellow centre.

There are many other kinds of cactaceæ, all very curious plants, but the only one I shall describe to you particularly is the Opuntia cochinillifera, a kind of Indian fig, on which the insect feeds, which we call the cochineal.

When the cook prepares stewed pears, or any dish that should be of a pinkish hue, she generally puts cochineal in it to improve its colour. This is in fact

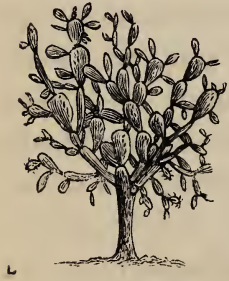

COCHINEAL CACTUS, OR NOPAL TREE.

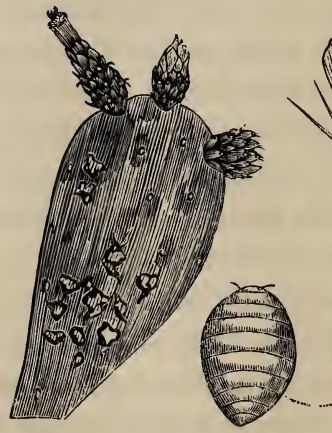

LEAF OF THE INDIAN FIG WITH THE INSECT FEEDING ON IT.
FEMALE INSECT.

MALE

INSECT.

a little dried insect (Coccus cacti), which, when alive, fed on a species of opuntia or Indian fig. The 
Indian figs have large flat, roundish, leaf-like stalks, and sometimes a white woolly substance is seen on these leaves like the American blight on apple trees. This is the covering of the female cochineal insect, and only the female insects are used for the dye. When fully grown, they are collected in the countries where the Indian fig grows, by women, who brush them off with the tail of a squirrel or a deer. They are then killed by dipping them in boiling water, or exposing them to heat in ovens, or the sun, and are then ready for sale. The substance called lac, of which sealing wax is made, is the produce of another species of coccus, which I shall speak of again by and by. Opuntias grow abundantly on the barren rocky soil of Mount Etna, and their fruit is commonly sold in the markets of the Sicilian towns.

\section{The Fig Marigold Tribe (Ficoidacea).}

The Mesembryanthemums or Fig Marigolds are also succulent plants, but they are natives of the sandy plains near the Cape of Good Hope. Nothing can be more sterile or desolate than the appearance of these plains during the dry season; but when the rains commence, thousands of mesembryanthemums spring up in every direction, opening their large star-like 
flowers, some of which are red, some yellow, and some white. The Ice Plant (Mesembryanthemum crystallinum) looks as if it were covered with little crystals of ice or rather frozen drops of water. It is an annual with white flowers, and is one of the few plants belonging to this genus, which is found wild in Europe. There are, however, other ice plants which are perrenials, and natives of the Cape of Good Hope, some of which have red and some yellow flowers, but all have the same glistening icy look, which must give so delightful a sensation of refreshing coolness in the burning arid deserts of which they are natives.

THE CAPER PLANT.

The capers which are used as a sauce to boiled mutton grow on a spiny plant (Capparis spinosa), which has been long cultivated in the south of France.

The principal caper plantations are near Marseilles, and they are said to have existed since the time Marseilles was a Greek colony. The plants, which are in rows, form little bushes each about four feet or five feet high. In the month of May, when the flower buds (which are what are called capers) first begin to appear, women and children are employed 
to pick them off; and they continue gathering some every day when the weather is fine, till the frosts begin in November. Every day's gathering is thrown into a cask with an addition of vinegar and salt, so as to keep the capers always well covered. Gathering these buds is hard work for the poor people employed, on account of the numerous spines of the plant. The

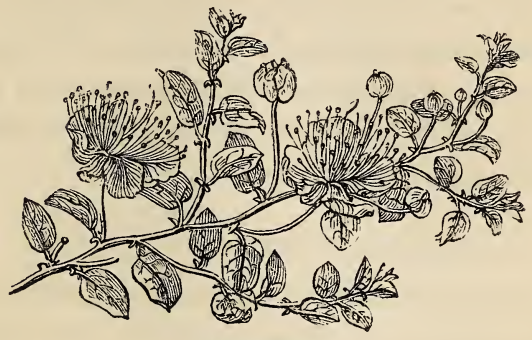

Caper flant.

flower of the caper is very handsome. The Caper belongs to the natural order Capparidaceæ.

\section{The Mignonette Tribe (Resedacece).}

The sweetness of the Mignonette (Reseda odorata) makes it a general favourite; though its flower is certainly far from pretty. It grows wild in the south of Europe, and in Asia ; and it is cultivated wherever there is a garden. You will be surprised to hear that 
there are above twenty different sorts of mignonette, some of which are natives of Great Britain; but none of them are sweet scented, except the common kind, and what is called the tree mignonette; which is only the common sort preserved through the winter, and trained up against a wall or to a stick, like a tree.

The yellow colour called Dutch pink, is produced from a kind of mignonette, called the Dyer's Weed (Reseda luteola), which grows wild in Britain. The nodding spike of this flower follows the sun; it is east in the morning, south at noon, west in the evening, and north at night.

\section{The Violet Tribe (Violacece).}

The Heartsease belongs to the violet tribe, and it is not only of the same natural order, but actually of the same genus as the violet. The botanic name of the heartsease is Viola tricolor, and that of the common sweet violet, Viola odorata. The heartsease is also called the Pansy, Love-and-Idleness, and a great many other names, which it would be tedious to repeat. It is invaluable in the flower garden, from its great variety, and the very long time it continues in flower. Some in my garden began to flower in March, and they will continue till October. Nay, 
if the winter be not too severe, a lingering flower or two will perhaps remain, till the whole mass again breaks forth into beauty.

You may save the seeds of the heartsease, and sow them, and when they come up, they will flower the first year; and you will have many, many new varieties. The heartsease is now grown as a florist's flower ; and the handsomest have many strange names given to them, and win prizes at floricultural exhibitions. I do not pretend to tell you these names. I do not know half of them; but I know the flowers they belong to are very beautiful, and give me great pleasure to look at them.

The Sweet Violet is also a beautiful little flower and from its hiding itself as it were beneath its large and bushy leaves, it has been made in floral language the emblem of modesty. Nothing can exceed the sweetness of this flower; and it is refreshing as well as fragrant. Many interesting anecdotes are related of the violet, but the one that has always pleased me most was that of John Bartram of Philadelphia, whose name afterwards become so celebrated as a naturalist.

This worthy man, who was brought up as a farmer, one day gathered a violet in his fields, and while 
thinking on some other subject, he stripped off the petals and sepals of the flower. When he had done so, he accidentally glanced at the remnant left in his hand, and was much struck with its singular shape. Here are the stamens and pistils of the heartsease, after the petals have been stripped off; taken from that excellent book the Ladies' Botany. The stamens and pistil of the violet are the same, but smaller. Bartram was so surprised at this odd shape that he gathered another flower, and examined it, and then another; in short, he was so much interested that when he went home and retired

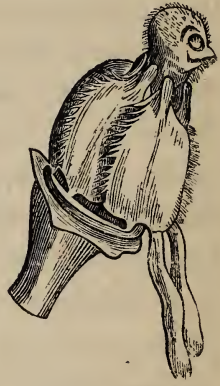

STAMENS AND PISTIL OF THE HEARTSEASE. to bed, he could think of nothing but the singular shape of the stamens and pistil of the violet. From this moment he studied botany; and finding the names of the plants were chiefly derived from the Greek and Latin, he made himself acquainted with those languages; and a knowledge of the medical properties of plants induced him to study physic.

Bartram now abandoned farming, and pursued the medical profession; spending all his leisure hours in collecting plants. About this time his fame reached 
the ears of Linnæus, who, after corresponding with him for some time, pronounced him to be "the greatest natural botanist in the world." $\mathrm{He}$ traversed North America, from Canada to Florida, in quest of plants ; and even made an excursion into East Florida after he was seventy years of age. He established the first botanic garden that was ever formed in America, and this garden, which is situated on the banks of the Schuylkill near Philadelphia, yet bears his name. Several foreign societies bestowed honours on him, and he was appointed American botanist to George the Third of England. Soon after this he died, in 1777, when he was seventy-six years old ; a striking example of the consequences that may arise from an inquiring mind being turned to the study of nature.

\section{QUESTIONS.}

1. In what country is the Pomegranate most abundant? 2. At which season of the year does the Witch Hazel blossom? 3. What does the Misletoe grow upon? 4. Of what country is the Cucumber a native? 5. What is the Cochineal, and what plant does it live apon? 6. What is the Ice plant? 7. What part of the Caper is eaten? 


\section{CHAP. X.}

THE PLANTS BELONGING TO THE CRUCIFERE. THE CABBAGE TRIBE. MODE OF MAKING SAUER KROUT. MUSTARD AND CRESS. SEA KALE. RADISH. CRUCIFEROUS FLOWERS, AND OTHER PLANTS BELONGING TO THE ORDER.

THE CRUCIFER AE.

This is one of the most extensive of the natural orders; as it contains above a hundred different genera, and nearly a thousand different species. It contains some of our most useful vegetables; as for example, the cabbage tribe, the turnip, the radish, and mustard and cress ; and many of our commonest weeds. All the plants belonging to it have the petals of their flowers somewhat in the shape of a cross, and hence the name of cruciferæ, which means literally cross-bearing. The seeds are contained in a kind of pod called a silique; like the seed pod of the horned poppy which I told you about long ago, but much shorter. All the cruciferous plants are eatable, as regards their leaves and roots; but their seeds are generally too stimulating to be used other- 
wise than as a medicine, or like mustard. Some of the roots are also too stimulating to be taken in large quantities, such as the horse radish, but the taste of these is too acrid for there being any danger of their being eaten immoderately. All the cruciferous plants abound in nitrogen; and as this is the principal gas evolved by decaying animal bodies, the smell of rotten cabbage stalks and leaves resembles that of putrid meat, and is nearly as unwholesome.

When Lord Anson went round the world about a hundred years ago, the surgeons who attended his expedition would not let the crew eat any vegetables at the newly-discovered islands they touched at, but grass; lest the strange herbs should poison them. This could never happen now. A very slight knowledge of the natural system would be sufficient to show what plants might be eaten without danger; and among others, surgeons at the present day would know that all plants with cruciferous flowers might safely be tasted, and if not found too acrid, eaten with the probability of their proving nourishing food; and also that all plants resembling the ranunculus, or having their flowers in umbels, should be carefully avoided, as being likely to prove poisonous. 
THE CARBAGE TRIBE.

It is difficult for a person who is just beginning the study of botany, to imagine that plants so different as the cabbage and the cauliflower, can belong to the same genus; yet not only do they both belong to the genus Brassica, but even to one species of that genus, Brassica oleracea. They are then only varieties, not differing more from each other, in a botanical point of view, than the different varieties of tulips, or the different kinds of heartsease.

The wild cabbage is found on the sea coast near Dover. It has sea-green leaves, with no appearance of a head, and when in flower it very much resembles wild mustard. The first variety is called in England Curly greens, or Borecole, and sometimes Scotch kale, or German greens. This vegetable is a great improvement on the wild cabbage; but there is still no appearance of a head, and the leaves are loose and open without affording much nourishment. The cow or tree cabbage, which grows twelve feet high, and which was so much talked of a year or two ago, is a subvariety of this kind.

Savoys are the next step. The curly leaves are still retained, but the plant has formed a head, and 
become decidedly a cabbage. The Brussels sprouts, which are so good when boiled and sent to table with melted butter and nutmeg, belong to this division.

We now come to the real cabbage, which forms a firm solid head, and is perhaps the most nourishing of all vegetables, not excepting even the potatoe. It is, however, so strong and rank in its taste, that few delicate stomachs can digest it. From a subvariety of this kind called in England the Drum-head or Dutch cabbage, the Germans make their favourite dish called sauer krout. The red cabbage used in England for pickling in vinegar also belongs to this division.

Would you like to know how the Germans make their sauer krout? If you would, I will tell you. In October and November the markets in most of the towns of Germany are crowded with huge piles of cabbages, since every family buys enough to make two or three large casks of krout, to serve them as vegetables all the winter; and at the same season men may be seen in the streets with a machine over their shoulders, ready to be hired for cutting the cabbages. This machine is like a small table with a ledge round it, and an opening in the middle, in which are fixed the blades of five knives, slanting 
with spaces between, so that when another frame filled quite tight with cabbages, is passed over them, the slices cut off the cabbages fall into a large tub below.

When the cabbages are all cut, a man takes as many of the shreds as will form a layer four inches thick, and puts them into a clean cask; be then strews over them two handfuls of salt, and a handful of unground pepper, with a little salad oil. He then puts on a pair of clean wooden shoes, and gets into the barrel, and treads the cabbage down till it is well mixed and smooth. He afterwards puts in other layers in the same way, treading each down, till the cask is full. A board is then put on the top, and kept down with heavy weights. In about a fortnight the cabbage begins to turn sour and ferment, and a green frothy liquid rises over the board, and swims at the top; the cask is then taken into the cellar, and the krout is considered fit for use.

The next division of the varieties of the species Brassica oleracea, that I shall tell you about, is the turnip-rooted cabbage ; commonly called by its German name of Kohl rabi. The upper part of the root and the stem of this vegetable are eaten, and not the leaves. 
The Cauliflowers and Brocoli are the last improvement which has taken place, and they are certainly the farthest removed from the parent plant. Nothing indeed can well be imagined more distinct than the close thick head of flowers of the brocoli, from the open single yellow flower of the wild cabbage. Both the brocoli and the cauliflower were first grown in the south of Europe. They differ chiefly in their size, and in the season of the year at which they are produced; the cauliflower supplying the table during summer, and the brocoli during winter.

The Turnip (Brassica rapa) is properly speaking a biennial, for it does not ripen its seed till the second summer after sowing. The turnips that are wanted for food are sown in the spring, and taken up in the autumn for use; but those roots that are wanted to produce seed are left in the ground all the winter, that they may send up a flower stem the following summer. Turnips are not only good for human food, but are very useful for feeding cattle.

The Swedish turnip is a variety of another species, Brassica campestris, which itself is grown on the continent, under the name of Colza, for oil. The Swedish turnip is thought very nourishing for cattle, and it is grown on a large scale for feeding them. 
The Rape (Brassica napus), which is grown for oil, also belongs to the cabbage tribe.

\section{MUSTARD AND CRESS.}

These two plants are so commonly associated in our minds as salad plants, that I have classed them together, though in fact, they belong to two different genera. I shall tell you about the mustard first. There are two very distinct species of this plant in common use. The Black Mustard (Sinapis nigra) is the kind grown for producing mustard flour. The plants are sown in rows, and hoed up so as to encourage them to run to seed. They soon send up tall flower stalks, and in August or September the seed is ripe. The plants are then reaped and tied up in sheaves. When sufficiently dry, they are taken to the barn and threshed; and the husks having been first taken off by a very ingenious machine, the seeds are ground into flour, which is sold by the druggists, and mixed with water before sending to table. The French do not take the husks off the seeds, and therefore their mustard is always black, and when they use it, they mix the flour with salt and vinegar. The ready made mustard that is sold in stone bottles is boiled with horse radish, and other ingredients to 
make it keep. The mustard used in England is principally grown in Durham.

The White Mustard (Sinapis alba) is principally used for salads; for which purpose the seeds are sown very thick, and the plants cut off while yet in their seed leaves. The plants grown for seed are principally cultivated in Kent. Some years ago, it was the fashion to swallow white mustard seed whole, to cure several kinds of diseases, but I never heard of its doing much good. This kind is generally used to make mustard plasters.

The Garden Cress (Lepidium sativum) is only cultivated as a small salad. It is a native of Persia and the Island of Cyprus; but it was introduced into England about three hundred years ago, and has been preserved ever since. It is rather a curious thing that an annual, of no beauty, the native of a warm climate, and grown merely as an article of luxury (for it is of little use as affording nourishment), should have been kept in cultivation so long, when so many interesting plants have been since introduced and lost for want of care.

The Water Cress (Nasturtium officinale) is a native of Britain, and generally it is the wild plants that are gathered for sale. It has, however, been culti- 
vated by planting it in the bed of a clear running stream, in rows, in the direction of the current. You will be surprised to see that the botanic name for this plant is Nasturtium, as the plant you have been used to call by that name is so very different; but the fact is, that the nasturtium of the gardens was so called because the taste of its young shoots resembled that of water cress.

OTHER VEGETABLES OF THE CRUCIFER瓜.

The Sea Kale (Crambe maritima) is one of the few vegetables not improved by culture. It grows wild on the sea coast, in various parts of Europe, and particularly in the west of England, where the inhabitants, from time immemorial, have been in the habit of watching when the shoots and leaf stalks begin to push through the sand and gravel in March and April. As soon as they see the heads of the shoots beginning to appear, they cut them off underground, as is done with asparagus. About sixty or seventy years ago, Mr. Curtis, who wrote many works on plants, happened to be travelling in that part of the country, and chanced to observe this practice; and he was so much pleased with the flavour of the sea kale, that he took some roots of it 
back with him to London. Before that time it was not grown in gardens, but now it is common there; and the gardeners imitate its natural mode of growth by burying it in sand, or covering it with earth, litter, or earthen pots, to keep it from the light.

The Radish (Raphanus sativus) is a well known garden vegetable, and its seeds come up so soon after being sown, that the plant has received the generic name of raphanus, from two Greek words, signifying to appear quickly. There are many sorts of radishes; but the two great divisions are the turnip or summer radishes, which are round, and generally white, and the spring radishes, which are long and generally red. The radish is a native of China, Japan, and Western Asia; but it was introduced into England before 1548 , and the varieties have been mostly raised in England and France.

THE ORNAMENTAL FLOWERS BELONGING TO THE CRUCIFERÆ.

Among the ornamental flowers comprised in this order are the Stocks, the Wall Flowers, the Garden Rocket, and the Candy Tuft; besides many others, such as the Alyssum saxatile or Yellow Madwort, the Arabis alba or White Wall Cress, the Sweet 
White Alyssum (Koniga maritima), the Yellow Whitlow Grass (Draba verna), the Tower Mustard (Turritis), and Buckler Mustard (Biscutella), which I shall only slightly mention, because I do not wish to confuse your memory, by telling you the names of too many plants that are nearly alike. I shall, therefore, only tell you particulars about the first four that I have enumerated.

The stocks are perhaps the most beautiful of cruciferous flowers. The Ten-week Stock (Mathiola annua) is a splendid plant, sometimes growing two feet high or more, and sending forth branches terminating in thick spikes of flowers. It is not generally, however, above a foot high, and the handsomest of the double varieties are those called German Stocks. The richness and variety of the colours, and the fragrance of the flowers, render this a most valuable ornament to the garden. It grows best in chalky soils, in warm sheltered situations ; for it is a native of the south of Europe, though it has been grown in England more than a hundred years. The Stock Gilliflower (Mathiola incana) is a native of England, and is found wild on the rocks about Hastings. It differs from the other principally in having its leaves of a bluish green, and covered with a soft down. The 
Brompton and white stocks are varieties of this species.

The Night Smelling Stock (Mathiola tristis) is not remarkable for the beauty of its flowers, which are of a dirty green, or livid colour, but it is curious, as it gives out its scent only at night. It and the Virginian Stock (Malcomia maritima) are both natives of the shores of the Mediterranean. The latter is an annual, and is very common in gardens.

The common Wallflowers (Cheiranthus cheiri) vary in colour from a clear yellow to a rich reddish brown, and their fragrance is delightful. They are natives of Europe, and have been cultivated in British gardens since 1573. The Shrubby Wallflower (Cheiranthus fruticulosus) is a native of Britain, and very common on old walls.

The Purple Candy Tuft (Iberis umbellata) is a very pretty annual flower; and there are several other annual, perennial, and shrubby kinds, which are very ornamental in a flower garden.

The Garden Rocket (Hesperis matronalis) is a very showy garden flower. It is sometimes called Dames' Violet, because between two and three hundred years ago, when beautiful flowers were not so common as they are at present, ladies were very fond of keeping it in their apartments. It is a native of 
the continent of Europe, and a variety of it is sometimes found wild in England.

OTHER PLANTS BELONGING TO THE CRUCIFERE.

I suppose you are now nearly tired of hearing about the Cruciferous plants, so I will only tell you of one or two more. The Cuckoo Flower (Cardamine pratensis) and the Shepherd's Purse (Capsella bursapastoris) are weeds belonging to this order. The former takes its name from its making the meadows white with flowers, just about the time when the cuckoo begins to sing; and the latter is called the shepherd's purse, because its seed pod looks like a purse, and the little round seeds within it like very small pieces of money. The Winter Cress, or Herb of St. Barbara (Barbarea vulgaris), is also a weed; but the American Cress (Barbarea præcox) is grown in gardens as a spring salad.

The Dyer's Woad (Isatis tinctoria) is an interesting plant, not only because it is very much used in dyeing broad cloth blue, of which colour more cloth is dyed than any other (even black cloth being first dyed blue), but because it is the colour with which the ancient Britons painted their bodies. It was from the fondness of the Britons for this paint that they received their name: Brith being the Celtic word for 
paint. The woad was anciently much grown near Glastonbury, which takes its name from the Celtic word glas, which signifies blue.

The Rose of Jericho (Anastatica hierochuntica) is the last cruciferous plant I shall tell you about, and it is one of the most interesting, as it shows the wonderful manner in which our great Creator has provided for the preservation of its seeds. The rose of Jericho grows in sandy deserts, where its seeds, if dropped, would wither, and never produce young plants. To prevent this, when the seeds are ripe, the branches curve up into a kind of ball and enclose them; and as the roots soon wither, the wind rolls this ball along the sands, till perchance it reaches a place, which, from some cause or other, is then moist. As soon as the woody branches are exposed to damp, they become softened and unfold, the seed vessels open, and the seeds drop out in a place, the moisture of which soon makes them generate.

\section{QUESTIONS.}

1. What is the meaning of Cruciferous, and why is it applied to plants? 2. What are the most distinct varieties of the Cabbage tribe? 3. Why did the Garden Nasturtium receive that name? 4. What is remarkable about Sea Kale? 5. What are the principal flowers belonging to the Cruciferæ? 


\section{CHAP. XI.}

THE PASSION FLOWER. ST. JOHN'S WORT, AND OTHER SPECIES OF HYPERICUM. THE CAMELLIA. THE TEA PLANT. THE MAPLE AND SYCAMORE. THE DOOL TREE OF CASSILIS.

\section{THE PASSION FLOWER.}

When the Spaniards first discovered South America, they found, among many other plants that excited their wonder and admiration, a climbing shrub hanging from tree to tree, and covered with beautiful flowers different from any thing they had ever seen before. One day, when a Catholic priest was preaching the sufferings of Christ for man to the Peruvians, amidst the wild scenery of their native forests, his eye suddenly glanced on this curious flower, which hung in festoons from the trees above his head, and he fancied that he saw in it an illustration of the martyrdom he had been describing. To his heated imagination, the rings of threads which surround the cup of the flower, and are mottled with blue, crimson, and white, appeared the crown of thorns stained with blood; its five anthers he 
thought represented the five wounds received by our blessed Saviour; the three styles, the nails by

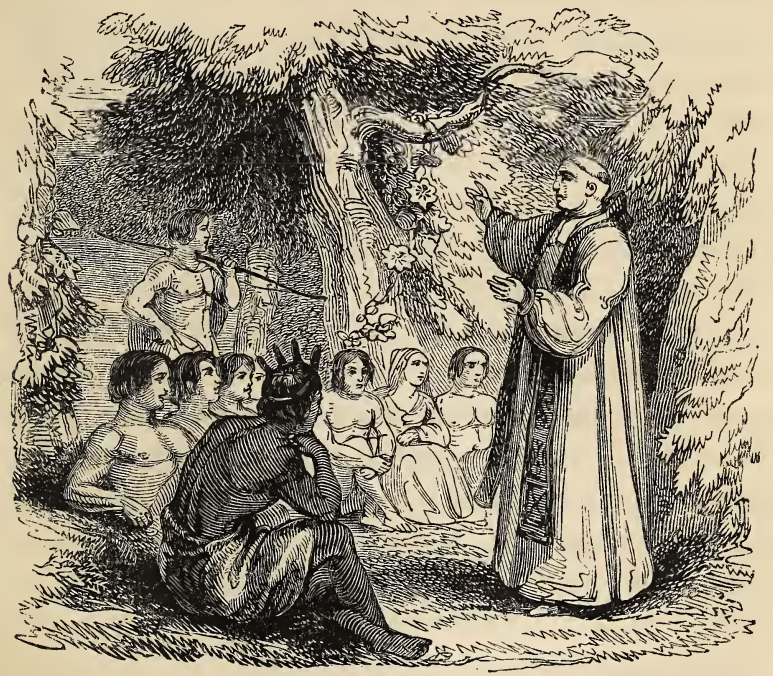

which he was fixed to the cross; and the singular column which rises from the bottom of the flower in the centre, the column to which he was bound. From this fancy, it was called the passion flower. The common Passion Flower (Passiflora cærulea) is blue; but there are others scarlet or crimson, and 
some white. The fruit, which is generally about the size of a common hen's egg, is sometimes yellowish and sometimes purple. It is filled with numerous seeds and a slightly acid pulp, which is very refreshing in a warm country. The fruit of all the kinds is known by the common name of granadillas. The natural order Passifloraceæ comprises only the passion flowers

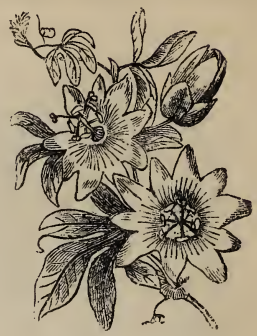

PASSION FLOWER. and the genus Tacsonia, the flower of which is pink, and scarcely distinguishable from that of the passion flower by any but botanical eyes. The fruit of the tacsonia is round, and it hangs among the leaves like a little golden ball.

\section{THE PAPAW TREE.}

The common Papaw (Carica papaya) is a native of India, but there are other kinds found in South America. The fruit, which is something like a cucumber in its appearance and seeds, is eaten by the natives of the countries in which it grows; but its most remarkable property is, that if very old pigs or poultry are fed with it for a few days before they are killed, 
their flesh becomes tender instead of tough. If newly killed meat of any kind be hung up among the leaves, it will also become tender in a few hours. This tree belongs to the natural order Papayaceæ.

\section{ST. JOHN'S WORT.}

One of the most curious of the native British plants is the common St. John's Wort (Hypericum perforatum). The flowers are of a bright yellow, with a margin round each petal of little red spots that look like drops of blood; the leaves are also spotted round their margins with purplish spots, and when held up to the light, they will be found filled with transparent dots, so large and clear, as to look like holes. These dots gave rise to the French name for the plant of mille pertuis, thousand holes. The specific name of perforatum, which signifies perforated, also alludes to them.

As you no doubt remember that the dots in the leaves of the myrtaceæ were little cells filled with a fragrant kind of oil, you will perhaps be curious to know the use of those of this plant. They are filled with a dark purplish or crimson oil, which is not fragrant, and which stains the fingers like blood when the leaf is rubbed. From the plant thus ap- 
pearing to bleed at the slightest touch, and the blood-like spots on its flowers, it was formerly believed to have sprung from the blood of John the Baptist; and many country people still fancy that a sprig of it, gathered on St. John's day, will serve as a charm against witches, and preserve them from all danger of being attacked by evil spirits!

There are many kinds of St. John's wort, one of which (Androsæmum officinale) is called Park Leaves, because it is generally found wild in parks under the shade of trees. Another kind (Hypericum calycinum) is called the Terrestrial Sun, because its large golden yellow flowers, with their long ray-like stamens, lie on the thick bed formed by their broad, shining, dark green leaves, and glitter like little suns.

All these plants, and many others, belong to the natural order Hypericaceæ, and they are distinguished by their dotted leaves, and by the large bunch of stamens in the centre of each flower being divided into five little tufts, each of which may be pulled out separately without injuring the others.

\section{GAMBOGE.}

The bright yellow colour called gamboge is the produce of a plant called Garcinia Cambogia, or the 
Gamboge Tree, a native of Siam, where it grows as large as an English oak. The leaves are large and shining, the flowers are yellow, and the fruit, which is eatable, is whitish when ripe. The gamboge is a kind of gum, which oozes out from incisions made in the bark of the tree. It is used in medicine, but it is poisonous when taken alone, and causes violent sickness. I knew a little girl who was very ill from having put her camel hair pencil frequently in her mouth while she was painting with this colour. The gamboge tree belongs to the natural order Guttiferæ; and the delicious Indian fruit called the magosteen belongs to the same order.

\section{THE CAMELLIA.}

It is just one hundred years since the Camellia japonica, or Japan rose was first brought to England. There was then only one kind, the single red, known, and it was sold at an enormous price. Now let any one in March or April visit the Camellia houses of Messrs. Chandler at Vauxhall, or Messrs. Loddiges at Hackney, and he will be struck with astonishment at the number and variety of these beautiful plants. As there are more than fifty sorts, besides numerous subvarieties, in cultivation, I shall not attempt to describe any of them particularly. 
The single red camellia is not so handsome as the double varieties, which are like roses, and there is one kind, the Waratah Camellia that has a flower like an anemone. When the Camellia was first brought to England from China (in which country it is found wild as well as in Japan) the nobleman who imported it, Lord Petre, had it put into his hothouse; but this was too warm for the poor camellia, and it soon died. It

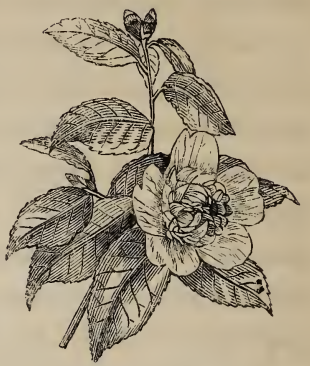

ANEMONE FLOWERED camellia. was then re-imported and tried in a greenhouse, where it did very well, and it is now found to live about London, and in the south of England, in the open air. It does best, however, in a conservatory, where it has not too much light, and is abundantly supplied with water.

\section{THE TEA PLANT.}

The green tea tree (Thea viridis) only differs botanically from the camellia in the formation of its capsule, and the divisions of its calyx. The flower to the eye appears more like that of the myrtle, except that the bunch of stamens in its centre is of a 
bright yellow instead of white. The black tea (Thea Bohea) has both the leaves and flowers much smaller than the green, and the whole plant is more tender.

Great doubts have been long entertained by botanists, whether the green and black teas that we buy in the shops, were all made from the same plant; or whether they were separately the produce of the plants called the green and the black tea. Those doubts, however, appear to be now decided by the discovery of the green tea only at Assam in India; and the fact, that both green and black tea of several kinds have been made from the leaves of that plant.

The green tea tree in its wild state grows to the height of twenty feet; but its leaves, when this is the case, are too tough and leathery to be used as tea. There is in fact almost as much difference between the cultivated and wild tea, as between the cultivated and wild cabbage; and that you know, as I have already

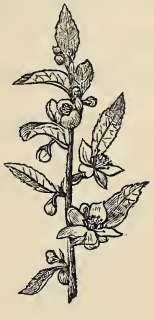

BLACK TEA.

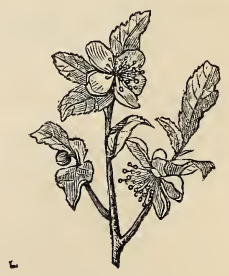

GREEN TEA。 told you, is very great. The tea sold in the shops is 
all made from low bushes, planted in rows, in ground which has been well manured, and is kept constantly watered; and this rich moist soil is absolutely essential to make the leaves sufficiently tender to be rolled up as tea.

The ground for the tea plantation having been ploughed and well manured, the seeds are sown in little patches at regular distances; and when the young plants come up, they are carefully watered, and weeded, and hoed up. The second year these processes are repeated, and manure is laid between the rows; and the third year the leaves are ready for gathering. Whenever the plants grow more than six feet high they are cut down to the roots, which soon send up a fresh supply of young shoots, and this is generally done, whether they have attained that height or not, every seven years.

The care which is bestowed on gathering the tea is extraordinary: each leaf is pulled off separately, and the gatherers are compelled to wash their hands frequently; for the finer sorts, they are, indeed, obliged to wear gloves. The most valuable teas, such as the green tea called Gunpowder, and the black tea called Pekoe, are made from the youngest and tenderest leaves. Hyson and Imperial Green, and Souchong 
and Congou are made from older leaves; and Bohea from the oldest and coarsest of all. The green tea is

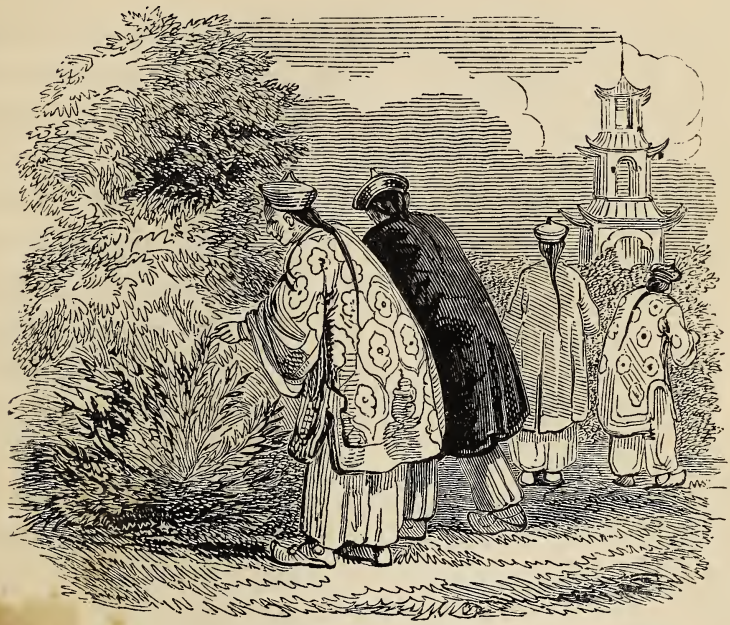

CHINESE GATHERING TEA.

dried on hot iron plates over a furnace, and the black tea in the sun. Both kinds are frequently rolled with the hands during the process of drying; and when rolled they are fanned, in order to cool them suddenly, and to make the leaves retain their curl. 
Tea was first brought to England in 1650, and it was kept ready made in the coffee houses, and sent out cold to persons who wished to buy it like beer. It was reckoned very wholesome, and people, when they felt poorly, sent to the coffee houses for a quarter or half a pint of tea to do them good. This was in the time of Charles II. In the reign of Anne, we first read of people making tea at their own houses, but the tea pots and tea cups were so very small, that it must still have been looked upon as a great luxury. Now the quantity imported into England every year, exceeds six millions of pounds.

In France, tea is still looked upon by the common people as a medicine. When I lived in that country, the servant who waited upon me, one day complained of the headache, and as I was going to make myself some tea, I asked her if she would have a cup. "No sir," replied she, apparently quite offended, "thank God, I am not bad enough for that."

The camellia, and the tea, belong to the natural order Ternstrœmiaceæ, which contains many other plants; but none I think, that would be interesting to you. They are nearly all natives of hot climates; and even the few that are hardy, are but little known in England. 
THE MAPLE, AND SYCAMORE.

After having told you about the tea plant, it appear's quite natural to tell you now about a tree that produces sugar. Not the sugar of the English shops, but a substitute for it, frequently used for it in my native country, America. I allude to the Sugar Maple (Acer saccharinum). Of this noble tree there are immense forests in North America, some of the trees in which are from eighty to a hundred feet high. In the month of February, when the snow is still on the ground, the sugar makers bore a hole in each tree, fixing to it a hollow tube, the other end of which rests in a large tub. In this way they proceed till all the sugar maples in a given space are pierced. The sap flows down the tube, and as each tub is filled, it is emptied into the boilers which are placed in a shed erected in the forest. The boiling turns the sap into a coarse brown sugar, by evaporating its watery particles ; and this sugar is afterwards refined. About three or four pounds of sugar are produced every year from each tree.

It is a wild scene, that sugar boiling in the forest; particularly at night, when the fires in the boiling sheds gleam through the trees; and figures of the 
tall brawny sugar boilers, look like demons employed in some unearthly revel. It is probable, however,

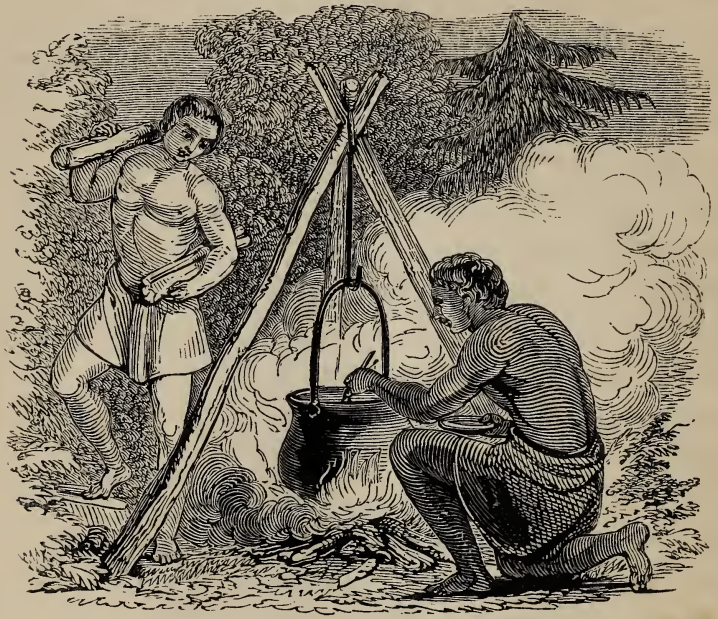

that this mode of making sugar will soon pass away, and be almost forgotten; since, as roads and commerce improve in America, the produce of the sugar cane will be to be purchased cheaper even in the remotest provinces, than the native sugar can be made.

There are many other kinds of maple; the com- 
monest of which, in England, is that found in the hedges of fields. Then there is the American Red Maple (Acer rubrum), which, in spring, when it first comes into flower, looks like a scarlet column; the Norway Maple (Acer platanoides), and the Sycamore (Acer Pseudo-Platanus), the leaves of which turn of such a beautiful colour in autumn. This tree is interesting in Scotland (where they call it the Plane tree, and the real plane tree, the sycamore), because all the Dool trees are of this species. Do you know what a Dool tree is? No, you never heard of such a tree. Then I will tell you a story connected with one which is yet standing in Scotland.

THE DOOL TREE OF CASSILIS.

In ancient times, when the great lords of Scotland held feudal sway over their vassals, and had the power of putting criminals, or indeed any person who had offended them, to death, every castle had a dool tree in its grounds.

Dool in broad Scotch signifies grief and wailing, and the tree was well called by this name; for great was the sorrow felt under its boughs. On this tree, the barons hung all their offending vassals ; and many a scene of cruelty and oppression did it witness. 
Near the ancient castle of Cassilis in Ayrshire, there is a large sycamore yet standing, on the branches of which have been hung many men. The tree stands on a raised platform of three or four steps cut in the turf, and is just before the windows of the castle, while a branch of the river runs dark and silently through the woods below.

This castle was the ancient seat of the Earls of Cassilis; and when Mary was queen of Scotland, about three hundred years ago, the earl, who then owned it, was unmarried, and the last descendant of his race. He was a brave warrior, but he had no beauty calculated to win a lady's heart; and as he was past the middle age, and had passed the greater part of his life in camps, he was stern and harsh in his manners.

In a small mansion not very far from the castle, lived a French gentleman who had followed the fortunes of Mary when she left France, and had settled in Scotland. This gentleman had lost his wife, and fearing the bad example of the court for his daughter, his only child, he had retired with her to this small estate. Rosalie, for that was her name, was very beautiful; and young as she was, for she was not yet seventeen, she had a lover; but unfortunately it was 
one whom her father did not approve of. Sir John Faa was one of the tallest and handsomest knights of Queen Mary's court, and he was also one of the most accomplished. His disposition, however, was not equal to his outward graces; he was bold and reckless, in the habit of yielding without consideration to the gratification of the moment, and totally heedless of every body but himself.

With this man the young and simple Rosalie was deeply in love; and like a silly girl, being pleased with his person and manners, she fancied him as amiable as herself. Her father, however, judged more wisely; and when he saw repeated instances of Sir John's selfishness and want of principle, he trembled for the happiness of his daughter. To remove her from the presence of this dangerous knight was one of the reasons which induced the father of Rosalie to retire to Ayrshire ; and when, soon after their arrival there, he found that Rosalie had pleased the Earl of Cassilis, he was most anxious that she should accept the earl's hand.

Rosalie was good, but she was timid, and though she would have preferred death to marrying the earl, she had not strength of mind enough to tell him the truth. Bitterly did she afterwards repent her weak- 
ness; and bitterly will any one repent, who has not courage to do what he knows to be right. More crimes are committed through weakness, than positive wickedness; and the man who is afraid to do right, will soon and easily be led to do wrong. About this time, news came from Edinburgh that Sir John Faa had quarrelled and fought with another knight in the queen's presence; and that for this offence he had been banished from the court. This news served to deprive Rosalie of her last hope; and fancying her lover lost to her for ever, she at length consented to become Countess of Cassilis.

Great was the rejoicing in the castle of Cassilis at the marriage of its lord; and who that saw the homage paid to the young countess, as she sat in all her beauty and rich attire, at the head of the feast, could have guessed that she envied the meanest of her vassals. Yet such was the case; and the young and beautiful countess would willingly have consented to become a peasant girl, and be obliged to labour hard all the rest of her life, to be free from the bonds she had just taken upon herself.

For some months after their marriage, the Earl of Cassilis excused the constant melancholy and shyness of his wife; as he thought these feelings arose from 
timidity and regret at parting with her father, who had returned to France; but as time went on, and he found her sadness still continue, he became uneasy at it, and frequently pondered on it in his mind, to endeavour to discover its cause. The earl knew nothing of the attachment which Rosalie had had for Sir John Faa ; and being unable to discover any other cause for his wife's repugnance to him, he at last concluded that it arose from personal dislike to himself. This was a horrid thought, but the conviction of its truth became stronger and stronger every day; and as this feeling increased, he found the former love he had had for his wife turn into hatred.

Wretched indeed were now this unhappy pair; they seldom spoke when they met, and the uneasiness they felt when in each other's presence was so great, that it was a positive relief to both when the earl received a command to join his regiment to assist in quelling the insurrection occasioned by Queen Mary's marriage with Lord Darnley. When the earl first quitted the castle, Rosalie felt his absence a relief; but many days had not elapsed before she began to feel an indescribable sensation of loneliness and melancholy oppress her. While she was in this state of depression her favourite attendant came one 
day into her room, and told her that a wandering minstrel had arrived at the castle, who played so delightfully, that she thought it would do her lady good to hear him. Rosalie was glad of any change, and after a little hesitation she ordered the wandering minstrel to be admitted into her presence.

This minstrel was Sir John Faa, who finding himself exiled from the court, and having dissipated his fortune in extravagance, had joined a gang of gipsies, and been elected their king. What passed between them I do not know, but the same weakness which made Rosalie accept a man she hated, made her disposed to listen to the persuasions of a man whom she fancied that she loved; and at last she had the wickedness to consent to leave her husband, and fly with her former lover. In the dead of the night, disguised in a suit of clothes which belonged to her page, and assisted by the gipsies, this weak woman escaped through a window of the castle, and proceeded to the banks of the river Doon, which runs through the grounds, and where she stood irresolute for some time, unable to decide whether she would go or return to the castle. The gipsy king did not suffer her long to hesitate, but taking her up in his arms, he carried her across the stream to where 
the horses belonging to the gang were waiting on the other side; and they were soon in a gipsy encampment far from the domains of Cassilis.

When the lady was missed from the castle, there was great confusion and distress, and a messenger was sent to inform the earl, whose rage was unbounded, when he heard what had happened. In the violence of his passion he vowed that he would exterminate all the gipsies in the kingdom, if he could not discover the villain who had stolen his lady; and the insurrection being over, he returned to his castle, with the vassals that had followed him to the wars, determined to punish his enemy.

The gipsy king, in the mean time, had made preparations for leaving the kingdom, but the night before he sailed he was betrayed by one of his own men; and he and the lady, with seven of the gipsies, were conveyed back to Cassilis. You may easily suppose Johnny Faa and his men met but with little mercy from the hands of the offended earl. They were all hung on the arm of that dool tree, which is still standing at Cassilis ; and the unhappy woman, whose weakness had been the cause of all this misery, was forcibly held up by two men, and compelled to witness the execution from the very window through which 
she had escaped. It was the mark of her little foot, when she stood irresolute on the banks of the Doon, which gave the earl the first clue to trace the gipsies; one of whom he afterwards bribed to betray them. Johnny Faa attempted to address the people while he stood upon the platform under the fatal tree, but the

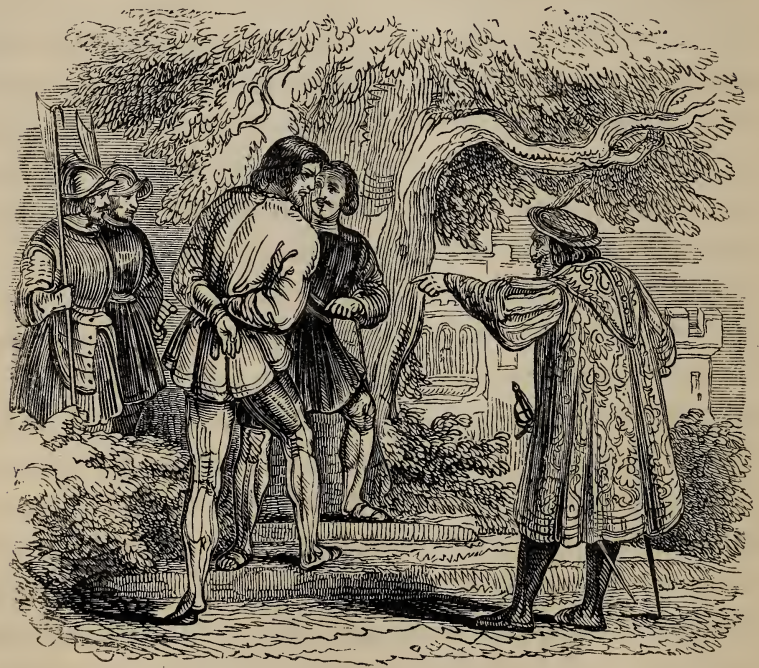

earl would not suffer him to speak, and ordered the executioner to proceed. The lady never recovered 
the shock of that dreadful night; and after her death, the earl, disgusted with the world, became a monk in the neighbouring monastery of Crossragnel, while the estates and titles of Cassilis passed to the Barons Kennedy, another branch of the family.

Such were the dreadful effects of want of principle, and weakness of resolution. Rosalie became wicked for want of courage to do right; and her wickedness brought death or misery to all connected with her.

\section{QUESTIONS.}

1. What do the country people believe about St. John's Wort? 2. What shrub does the tea plant most closely resemble? 3. Why is it now known that the green and black tea are to be made from the same plant? 4. From what tree do the Americans make sugar? 5. What is a Dool tree?

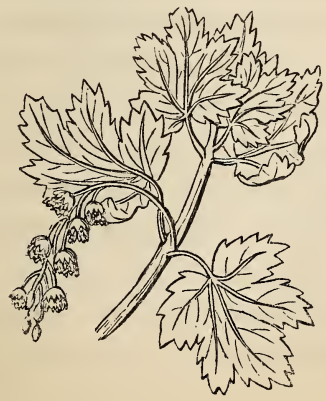




\section{CHAP. XIII.}

THE HORSE CHESTNUT. FLAX. THE COTTON PLANT, AND OTHER PLANTS BELONGING TO THE MALLOW TRIBE. THE ROCK ROSE TRIBE. THE LIME TREE. THE MAHOGANY TREE. SATIN WOOD. THE BEAD TREE, PRIDE OF INDIA, AND INDIAN LILAC. PURPLE WILLOW HERB, AND HENNA. ORANGES AND LEMONS. THE JUJUBE AND OTHER PLANTS BELONGING TO THE BUCKTHORN TRIBE. PLANTS BELONGING TO THE CROWBERRY, STAFF TREE, AND BLADDER NUT TRIBES. THE ROMAN CATHOLIC ROSARY.

\section{THE HORSE CHESTNUT.}

THE common horse chestnut is almost the only tree common in the parks and plantations of England which is remarkable for its flowers. It has been compared to a giant's nosegay, and each spike of flowers to a gigantic lupin, or an enormous hyacinth ; but I think the best comparison is that of a great candelabra, with its large branches stretching out like arms, and its spikes of flowers tapering upwards like lights.

The common Horse Chestnut (Æsculus Hippocastanum) has flowers which are very nearly white; 
but the Scarlet Horse Chestnut (Esculus rubicunda) has its flowers of a bright scarlet. Both these kinds, and several others, all belonging to the genus Esculus, have their nuts enclosed in a rough husk. The genus Pavia, called in America Buckeye, has its nuts enclosed in a smooth husk. There is one Pavia with deep red flowers (Pavia rubra), and another with yellow flowers (Pavia flava), both of which look well in a shrubbery; but the most beautiful of the genus is the white-flowered Buckeye (Pavia macrostachya). This is a low tree, seldom exceeding twenty feet in height, and often not more than ten or twelve feet. It comes into flower a month or six weeks later than the other species of the genus, and continues in beauty for a longer time. The fruit is small, but eatable, and the country people in America are very fond of it, either boiled or roasted. It is the only kind of horse chestnut that is eatable that I know of. The flowers are very beautiful, from their long white stamens, which give them a kind of feathery lightness; and the leaves hang down gracefully from the length of their footstalks. All the horse chestnuts belong to the natural order ÆEsculaceæ. 


\section{FLA X.}

I am now going to tell you about a very interesting plant, I mean the common Flax (Linum usitatissimum), from which all our linen is made. It is an annual plant, growing about two feet or three feet high, with narrow leaves, and blue flowers. It is found wild in Britain, and indeed throughout Europe, as well as in North America, and in some parts of Asia; but it is said to have been originally from Egypt. It has been very long cultivated in this country, both for its fibres, and its seeds, which are called linseed, and used for making oil.

Flax is sown very thick in fields properly prepared for the purpose. When the stalks begin to turn yellow, they are cut with a reaping-hook, and laid in small sheaves or handfuls, across each other, on the field. When they have lain two or three days, the capsules containing the seeds are pulled off the stalks. This process is called rippling. A large cloth is laid on the field, and an instrument called a ripple is placed in the middle of it. This instrument is an iron comb fixed in a beam of wood, on the ends of which sit two persons, who, by pulling the seed 
ends of the flax repeatedly through the comb, soon detach the capsules from the stalks.

When the flax has been rippled, the stalks are tied together in sheaves, and put into a pond to steep. Here they remain covered with water for ten or twelve days; they are then taken out, and the stalks spread loosely over the field to bleach. In a few days the stalk part, or what is called the boom, becomes brittle, and will break when taken up in the hand, leaving the harl, or fibrous part uninjured. The flax is now taken to the mill, where it undergoes the operation of scutching, hacking, or breaking, by which the woody part is broken and detached from the fibre; and heckling and combing, by which the fibre is cleared from the woody matter, and brought into a fit state to be spun.

I told you when I spoke of sowing the flax that it was sown very thick. This is to make the fibres fine; and it does indeed make the stalks so fine and slender, that in Flanders, where a great deal of flax is grown, the farmers are obliged to drive stakes into the ground at regular distances, to which they fasten cords, and thus form a support for the long slender stalks of flax. This has a singular appearance, particularly as these cords cross each other, 
and form a kind of gigantic net-work over the whole field. The ground is so light, that when the Flemish farmers sow their seeds they have their feet strapped to large pieces of board, to prevent them from sinking into the soil. When the flax comes up it must be weeded. The women and children, who do this work, tie pieces of coarse cloth round their knees, and then crawl along on their hands and knees to avoid hurting the tender shoots of the young flax. They also take care to keep their faces to the wind, that the young plants which have been bent down by the weight of their bodies, when they were creeping over them, may be raised again, when they have passed, by the wind.

The capsules, when separated from the stalks, are dried, and then threshed and winnowed. The linseed is afterwards taken to the mill, where it is crushed for making oil ; and the cake or husk which remains after the oil has been pressed out of it is used for fattening cattle, or for manure. Linseed oil is used by painters, and for a variety of other purposes; and the entire seeds are boiled to make a kind of tea, which is given to persons having bad coughs: they are also used for poultices.

There are many kinds of flax; but this is the only 
kind grown for use. Of the ornamental kinds some are yellow and some pink, as well as blue, and some have a purplish tinge, but all are very handsome, and well worth growing in a flower garden. The natural order of the flax is Linaceæ.

\section{THE COTTON PLANT.}

After telling you so much about the plant from which linen is made, you will naturally now like to hear something about that which produces cotton. The Cotton shrub (Gossypium Barbadense) is a native of the West Indies. It has large yellow flowers, with a purple spot at the base of each petal. The capsules are large, and they are lined with cotton, among which are imbedded the seeds. The cotton plants are raised from seed, like the tea plants; and they are sown in rows in very light rich soil. The shoots are never suffered to grow more than six feet high, and they produce two crops of cotton every year. When the seed pods are ripe they open, and show the cotton bursting out. When in this state, the capsules are gathered, and the wool is picked out of them, and carried to a kind of mill, where it is separated from the seeds. It is afterwards looked over, and any impurities that may 
remain in it having been picked out, it is packed in large sacks, and trodden down, the sacks being occasionally wetted on the outside, to make the cotton in them lie closer. It is then sent to England, where it is manufactured into cloth by some very curious machines, which it would take me too much time to describe; but which you will see if you should ever go to Manchester.

There are several other species of the same genus grown for their cotton, but the only one I shall tell you about is the Nankin Cotton plant (Gossypium religiosum). This plant grows wild in China and in Siam, and its cotton is naturally the colour of the nankin. This cloth therefore, when genuine, always washes well, because it is not dyed, and the natural colour only looks clearer and brighter when it has the dirt removed from it. This cloth takes its name from the greater part of it being manufactured in the city of Nanquin in China.

OTHER PLANTS BELONGING TO THE ORDER MALVACE $Æ$.

You will be surprised to hear that the cotton plant belongs to the same natural order as the Mallow (Malvaceæ). Yes, the common mallow that grows 
in the hedges, and that is so abundant in churchyards, belongs to the same family of plants as that valuable shrub which supplies half the civilized world with clothing. The common Mallow (Malva sylvestris) is a very curious plant when closely examined. You smile at this, and think naturally enough that nothing can be curious that is common. Alas! my dear children, long before you are as old as I am, you will have learned that you are surrounded by miracles that man, with all his boasted wisdom, cannot explain. We search and examine, and every step that we take towards acquiring a knowledge of nature shows how much there is to learn. How much skill and contrivance is shown in the formation of every flower! How beautifully every part is adapted to the purposes it is to perform, and how exquisitely every thing is finished, so that the most powerful microscope that we can use only shows us new beauties! Every thing in nature shows the work of an Almighty hand; and the more we study natural objects, the more we feel disposed to worship their Creator.

Let us look at this mallow. See how curiously the long, rosy, purplish petals are twisted in their buds! Here is one that is expanded; see how deli- 
cately it is veined! The stamens are gathered together into a kind of column, at the top of which are a number of curiously shaped anthers. Now let us examine the seed. It is contained in a collection of carpels, forming what children call the mallow cheese. This head or cheese may be eaten, and is perfectly harmless. If cut through with a knife, the two divisions will each form a vegetable star; and if examined, it will be found to consist of ten or twelve carpels, each of which contains a seed.

There are many kinds of mallow, but they are all so much alike that you will easily know them at first sight. Belonging to the same family are the bright scarlet Malope (Malope grandiflora); the pink and white Lavateras (Lavatera trimestris); the Bladder Ketmia (Hibiscus Africanus), with its cream-coloured petals, each having a rich velvety dark brown spot at its base; and the Althæa frutex (Hibiscus Syriacus), which is so ornamental in our gardens. To these may be added the common Marsh Mallow (Althæa officinalis), from which the French make the lozenges called Pate de Guimauve; the Hollyhock (Althæa rosea), with all its endless varieties of single and double, white, red, yellow, buff-coloured, and dark reddish purple; the splendid scarlet Hibiscus (Hibis- 
cus rosa-sinensis), which we see so often depicted in the Chinese paintings on tea-chests and china; and many other beautiful and splendid flowers.

\section{The Rock Rose Tribe (Cistacea).}

Those pretty little flowers with wrinkled petals of bright rose, yellow, or purple, which we so often see on rock-work, all belong to the order Cistaceæ, and to the two genera Cistus and Helianthemum. There are above a hundred species of the latter genus, all differing so little from each other, as to require the eyes of a botanist to distinguish them. There are not half so many kinds of Cistus, and some of them are quite distinct.

The Purple Cistus (Cistus purpureus) is one of the most common of the genus; but the Gum Cistus (Cistus Cyperius) is a handsome shrub, generally from two to four feet high, but some grow to above twice that height. The flowers are large (being sometimes three inches across), and white, each petal having a rich dark brownish crimson spot at its base. These flowers are very beautiful, but unfortunately they are very short-lived, and if they open in the morning the petals will probably have dropped before night. This species is frequently called Cistus lada- 
niferus, and is supposed to produce the gum ladanum; but this drug is produced by a different kind of Cistus. The Gum Cistus is also sometimes called Cistus salicifolius.

The Cretan Cistus (Cistus creticus) is the kind that bears the gum ladanum. This gum was formerly mixed with the preparation of opium and spirits of wine, which is still called laudanum, from the name of this gum, though the gum itself no longer forms a part of the composition. The gum ladanum exudes through the leaves of the plant, and looks like honey dew, and it is collected by an instrument in the shape of a rake with very long teeth, which, instead of being of wood or iron, are made of leather. In the island of Crete, when it is to be collected, five or six men, in the heat of the day, when there is not a breath of air stirring, pass through the shrubs, sweeping the leaves with their long whip-like rakes; the gum, which sticks to the leather thongs, is afterwards scraped off, and kneaded into cakes for sale.

\section{THE LIME TREE.}

Who is there that has not smelt the fragrance of the blossoms of the lime tree, or seen the bees clustering about them in the bright sunshine of a summer's 
day? The Lime Tree, or Linden, as it is sometimes called (Tilia europæa), forms a very agreeable shade, and on this account it is frequently used for planting public walks. The wood is very soft, and excellent for carving; but the most important part of the lime tree is the inner bark, which is used for forming the bast, or Russian mats.

These mats, which are in constant use in every garden for protecting trees from the frost, are made principally in Russia, where there are large forests of the lime tree. In spring, when the sap begins to move, and the bark will part readily from the tree, it is stripped off in pieces six or eight inches long. These are steeped in water till the inner bark will separate freely from its outer casing into what are called ribands, or strands. The strands are then hung up in the shade to dry, and in the course of the summer they are ready to be manufactured into mats.

There are many curious old lime trees in different parts of the world; but the most remarkable is one at Neustadt an der Linden, in Wirtemberg. This tree is partly decayed, but it is still about one hundred feet high, and in the centre of its ruined trunk, which is fifty-four feet in circumference, there is a 
kind of room in which visitors sit, and eat gooseberries from some gooseberry bushes that have sprung up from seed sown in the hollow part of the branches. Round the tree are one hundred and eight pillars, each supporting an enormous branch; and the room in the middle is ascended to by a flight of steps.

There are several kinds of lime trees, both European and American, and they all belong to the natural order Tiliaceæ.

\section{THE MAHOGANY TREE.}

When Sir Walter Raleigh was at the island of Trinidad, in 1595, his carpenter cut down some mahogany trees to repair the ship. The wood was then unknown, but the carpenter was so struck with its beauty, that he showed it to his master. At that time, however, Sir Walter had other things to think of. He had already found in Guiana as many new flowers and trees "as would be sufficient to make ten volumes of herbals;" and when he arrived at Trinidad, he had just gone through the horrors of a dreadful storm, which had rendered his vessels so leaky, that all the crew became very melancholy, before " they committed themselves to God's keeping and thrust out into the sea." And when Raleigh returned 
home, he found that his enemies had taken such advantage of his absence, to injure him with Queen Elizabeth, that all his attention was turned towards vindicating himself.

The mahogany appears to have remained after this unnoticed for many years, till a Dr. Gibbons, who resided in King Street, Covent Garden, having received a log of this wood from his brother, a West Indian planter, employed his carpenter to make a candle-box of some of it. The carpenter, whose name was Wollaston, complained that the wood was so hard that it spoiled his tools. The candle box was, however, at length finished, and the doctor was so pleased with it, that he had a bureau made of the same wood. The doctor attended the Duchess of Buckingham, who, when she heard of this new wood, also ordered a bureau of it; and, as her praises brought it into fashion, Wollaston, to whom every body applied to get their articles of furniture made, became rich, through the very log of which he had, at first, so bitterly complained.

The Mahogany Tree (Swietenia Mahagoni) is so called from the native name of the tree, Mahagoni. Its flowers are small, and of a greenish white; and its capsules are very large and prickly on the outside. The leaves are oval, and rather large; and the tree, 
which is lofty, has a very noble, and at the same time graceful appearance, from its branches drooping downwards. The best mahogany trees sent to Europe are grown at Honduras, and the proper age at which they should be cut down is two hundred years. The mode of finding them, and, when they are cut down, of dragging them to the water side, are so curious that I will tell you all I know about them.

The labourers employed to cut down the trees are divided into what are called gangs, consisting of from twenty to fifty each. Each gang has a person belonging to it who is called the huntsman, because it is his business to hunt out the trees. About the beginning of August the huntsman goes into the woods, and climbs the tallest tree he can find, looking down upon the mass of foliage below, to see if he can discover any trees the leaves of which have that reddish yellow tinge, which the leaves of the mahogany tree assume at this season. His practised eyes detect the wished for tree at an almost incredible distance; and when he descends from his post of observation, he leads his gang straight to the tree he had discovered, without guide or compass, trusting only to the acuteness of his eye, and the accuracy of his memory.

When a tree is cut down, a road is cleared for it 
through the dense mass of trees and underwood by which it is surrounded; the workmen cutting vigorously in all directions with their cutlasses and axes, till they have opened a road. The trees are then, after having been cut into logs of a convenient size, fixed on rough trucks with wheels, or merely swung

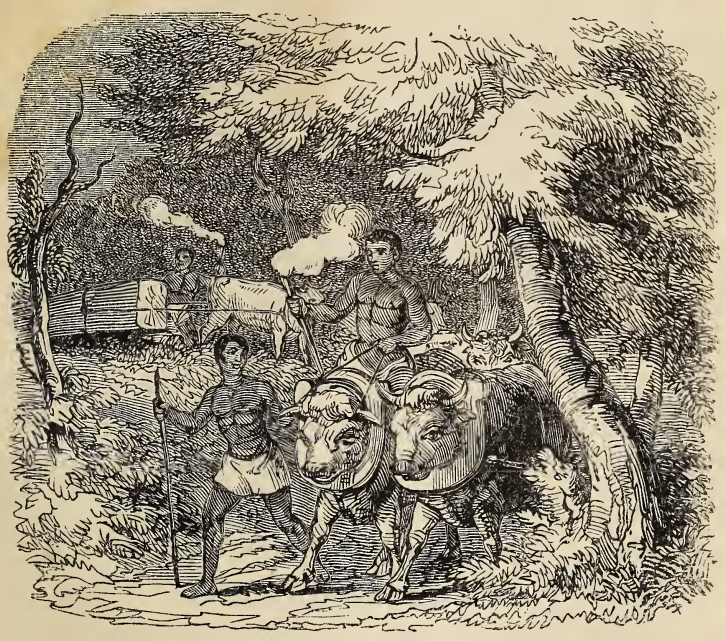

in chains and fastened to a yoke of oxen, seven pair of oxen, and eight or ten men, being required to each truck. These trucks always travel by night, (the 
heat of the day greatly increasing the labour of the oxen), and nothing can present a more extraordinary spectacle than a line of trucks coming dashing along over the rough road. They go fast, because the road generally slopes down to the water, and, when once set in motion, the more rapidly they go, the easier it is for the oxen. Thus then they go, crushing the remaining branches of underwood, and half removed trees as they hurry on; the chains rattling, the men shouting, and cracking their long whips, and the lighted torches they carry flashing at every step.

In this manner, the logs of mahogany are brought to the sea-shore, where they are shipped for Europe. There are several kinds of mahogany; but the best is the one we have already spoken of, and which grows in Honduras. The mahogany belongs to the natural order Cedrelaceæ; and there are some other interesting trees in that order; the most remarkable of which is the Satin wood (Chloroxylon swietenia); a tree with pinnate leaves and white flowers, a native of the East Indies, the wood of which, being very smooth and close grained, is used for making boxes, and inlaying, and of which formerly drawing room tables were made. Both the mahogany and the satin wood trees require a hothouse in England. 
TREES BELONGING TO MELIACER AND STERCULIACE $Æ$.

In the south of Europe is often seen a tree with pretty lilac flowers, and yellow berries. This tree is a native of India, and is called Melia Azedarach, or the Bead tree. The pulpy part of the fruit is poisonous, but the stones when cleaned are strung to make rosaries for the Roman Catholics. There is a species of this tree (Melia sempervirens) which is a native of the West Indies, and is called the Indian lilac, or Pride of India. The order Sterculiaceæ contains many plants; and among others the Theobroma Cacao, which grows in the West Indies, and the seeds of which are the cocoa nibs sold in the shops. To make chocolate these seeds are roasted, and then pounded in a mortar; after which the powder is mixed with water to make it into a paste, which is poured into a mould, and when taken out is wrapped in paper for sale.

\section{THE LYTHRACE床.}

Have you ever seen a tall growing plant with purple flowers on the banks of a running stream, which the country people call the Purple Willow herb? Its botanical name is Lythrum Salicaria, and 
it belongs to the order Lythraceæ. The Lagerstrœmia indica, or true Pride of India; the Cuphea, the flowers of which are of a very dark purple edged with white; and the Henna (Lawsonia inermis) which the Egyptian women use for staining their hands and feet, all belong to this order.

\section{The Citrus Tribe (Aurantiacece).}

I suppose you have seen an orange tree; but in case you have not, I will describe one. The tree is generally from ten to twenty feet high, with a naked trunk and a round bushy head. The leaves are smooth and shining, and they remain on the tree all the winter. The flowers are white, with a very sweet, but sickening smell. The fruit is round, and when ripe is of a golden yellow; its taste-but what need have I to describe the taste of a sweet orange to you? If you have not seen the tree, you have at least seen the fruit. You laugh. Well! well! I'll take it for granted that you know what an orange is ; and will go on telling you something about the orange tree which probably you do not know.

The sweet Orange Tree (Citrus Auranticum) is a native of Asia, though it has been cultivated from time immemorial in Europe. The principal orange 
plantations in Europe are those near Genoa in Italy, near Seville in Spain, and in Portugal. The oranges we have in England are principally from Portugal and the Azores. What is called the China orange is principally grown at Malta; it has a very thin rind, and sweet juice; while the Italian orange has a thick rind. The kind called the Malta orange is also grown in Malta; it has red pulp, and when ripe, it has a thin rind and very small seeds. The St. Michael oranges are small and very good; they come from the Azores. All these kinds, and many others are varieties of the common sweet orange.

The only orange that is really brought from China is the Mandarin orange (Citrus nobilis). The fruit of this species is reddish, and the rind is sweet and eatable, as well as the pulp. It is easily distinguished from all the other kinds, by the pulp separating of itself from the rind; so that you have only to cut open the rind, and you may take out the orange nicely peeled, without giving yourself any more trouble. This kind requires a hothouse in England. The Seville orange (Citrus vulgaris) is principally used in making wine or marmalade. The rind is thick and the pulp very bitter. Though this kind is called the Seville orange, the fruit of it used in 
England is principally grown in Italy, or in the south of France near Nice. Some of the varieties of this species are in very odd shapes; and one of these has two protuberances in its rind like horns.

The Lemon (Citrus Limonum) is as well known as the orange. The tree is more branched than the orange tree, and the branches are more spreading and do not form so round a head. The fruit of the lemon is paler than that of the orange; it is larger, and terminates at one end in a small protuberance. The rind is thick, and the pulp acid. There are a great many different kinds of lemon; but they all agree with the common kind in having oblong fruit, with a thick rind, and acid pulp.

The Lime (Citrus Limetta) may be called the sweet lemon. The tree is taller than that of the lemon, and the flowers larger and handsomer; but the fruit is round and small, with a very sweet pulp. The commonest kind is copper coloured, but there are other varieties with a golden yellow rind, and others with a pale yellow. The lime called Adam's Apple has a dark green rind, and bitterish pulp.

The Citron (Citrus Medica) was well known to the Romans, and the lemon tables spoken of by Pliny are supposed to have been made of the wood of this 
tree. I forgot that you, my little dears, have never read the works of Pliny. You have, however, no doubt, heard of him, and know that he was a Roman naturalist who lived in the time of the emperors Titus and Vespasian; and who wrote a work on natural history, which, though it contains some fables, and some very ridiculous stories, has yet the merit of containing a very interesting account of what was known about plants by the ancient Romans. The citron is very large, and is not eaten raw, but it makes a delicious preserve; and its acid is used in medicine. The Jews carry citrons in their hands at their great feast of the tabernacles.

The Forbidden Fruit (Citrus Paradisi) is the produce of a large tree. This fruit has scarcely any pulp, but the rind is tender, sweet, and eatable. It makes a fine preserve. The Shaddock (Citrus decumana) is the last of the orange tribe that I shall tell you about. It is the largest of them all, one fruit having been known to weigh above fourteen pounds. It is a native of China, but it has become almost naturalized in the West Indies, into which country it was introduced by a Captain Shaddock, whence its name. Its rind is thick, but the slightly acid flavour of its pulp is very agreeable, and it is excellent for 
quenching thirst; and, as it keeps a long time, it is valuable for sea voyages.

Oranges and lemons grow perfectly well in the open air in Italy, and similar climates; but in England they require a greenhouse. I have, however, seen an orange grove in England. Some years ago, at Nuneham Courtenay, in Oxfordshire, there was a grove of orange trees planted on the turf, so that persons might walk between them, and gather their fruit in the open air, or repose themselves on the seats that were placed under the trees. But how, you will ask, were these orange trees kept alive during winter? I will tell you. In the turf, at regular distances, were holes, each with a cover, like those made for putting in posts for drying clothes, and a piece of turf was put over each of these holes, in summer, to hide it. In winter, posts were put into the holes, and a wooden framework fastened to them, that was filled in, and warmed by stoves, so that the orange trees were kept quite warm and comfortable all winter, and ready to enjoy the summer when the boards were removed.

It is a curious thing about orange trees, that while they want plenty of light in summer, they will do with very little in winter, or indeed with none at all. 
In Paris they are taken in out of the gardens in November, and kept in a dark greenhouse, or, as is often the case, in a cellar, during winter, till the first of May, when their tubs are drawn out again into the open air. This is a gay day in Paris, and the gardens of the Tuilleries, and the Luxembourg, are always directly after filled with people, who come to look at and admire the orange trees as though they had never seen them before.

While I am talking about orange trees, I must not forget to tell you a curious mode of cheating which the Italian gardeners adopt with them. They get an orange tree and scoop out all the pith, which does not kill the tree, as the circulation of the sap is carried on from the root to the leaves through the bark. They then introduce a young rose tree and a jessa. mine, twining them together, so that their branches shall appear mixed, and leaving the roots out at the bottom, intermingled with the roots of the orange tree. They then put the plants thus curiously fastened together into rich soil, and when they begin to grow, show them as a rose and a jessamine grafted on an orange! This practice is called in France $l a$ greffe des charlatans.

You will perhaps ask why these people do not 
really graft the rose and the jessamine on the orange, instead of taking so much trouble to deceive ? The answer is, they cannot. No art of man has yet been able to graft plants belonging to one natural order on plants belonging to another, unless the two orders are very nearly allied: that is, resemble each other in a great many important points. This is not the case with the plants in question, as the rose, the jessamine, and the orange, belong to three different orders, and these orders differ widely from each other.

All the plants belonging to the orange tribe have their leaves, the petals of their flowers, and the rind of their fruit, studded with vesicles or little cells, filled with fragrant and pungent oil, like those I showed you in the leaves of the myrtle. The petals of the flowers are white and fleshy, or rather waxlike, and they are studded with green dots. The stamens are numerous, and grow together partially into a sort of column. The leaves are jointed above the footstalk, so as easily to break off at that point.

THE JUJUBE TREE AND OTHER PLANTS BELONGING TO THE ORDER RHAMNACEÆ.

Have you ever tasted jujube lozenges when you have had a cold? They are made from the fruit of 
the Jujube Tree (Zizyphus vulgàris). This is a small thorny tree, with pale yellow flowers, and oblong pulpy fruit, which becomes of a bright red when ripe. It is a native of Syria, but it has been so long grown in Italy and the South of France, that it now springs up naturally there.

Christ's Thorn (Paliurus aculeatus) was once considered a species of zizyphus. It has a very curiously shaped fruit, which the French call porte-chapeau, because it looks like a flat hat for carrying under the arm. The crown of thorns placed on the head of our blessed Saviour at the crucifixion, is supposed to have been made of this tree, which is abundant in Judea, and grows wild in many parts of Asia and Europe.

The Alaternus (Rhamnus alaternus) is an evergreen shrub, which was formerly much used for clipping into shapes of men and animals. The fruit of the Purging Buckthorn (Rhamnus catharticus) is used for making colours. When unripe, it is sold under the name of French berries for dying or staining yellow; when ripe, the juice is mixed with alum to make sap-green; and after it has hung on the tree during the autumn, the juice is used for dying purple. The bark and the berries, if eaten, form a strong 
purgative. This species is a native of Britain. The Avignon berries, which are used for staining leather yellow, are the fruit of another kind of Buckthorn (Rhamnus infectorius); and the berries of nearly all the species of the genus dye yellow.

The beautiful blue Ceanothus, or Red Root (Ceanothus azureus) belongs to this order, as does the New Jersey Tea (Ceanothus Americanus).

The Crowberry (Empetrum nigrum) is a little plant with black berries, that grows wild on the Scottish heaths. There is a kind with white berries, and another with red. The crowberry is the badge of the clan Maclean. The berries are good to eat, and are reckoned wholesome. It belongs to the natural order Empetraceæ.

The Spindle Tree (Euonymus europæus), the Staff Tree (Celastrus scandens), and several other plants, belong to the order Celastraceæ. The spindle tree is so called because the spindles used in Scotland in spinning flax are made of it. The American Spindle Tree (Euonymus latifolius) is a very handsome shrub. The French call the spindle tree Bonnet de Prêtre, from the singular manner in which the seeds, which are purple, hang down by their aril, which is bright orange, from the capsule, which is of a rose-colour. 
The aril is the skin that envelopes the seed, like the skin of the almond.

The order Staphylaceæ is principally remarkable for the Staphylea, or Bladder Nut Tree. The seeds of this tree, which are enclosed in a large bladdery capsule, are so hard and bead-like, that they are strung, like those of the Melia Azederach, for rosaries, in the Roman Catholic countries. Do you know what a rosary is? It is a string of beads, some large and some small, there being always ten small beads to every large one. When the rosary is used, the person praying says a short prayer to the Holy Virgin, called an Ave Maria, for every small bead, and the Lord's Prayer in Latin, which is called a Paternoster, for every large one; and what is called telling the beads, is saying one of these prayers for every bead in the rosary.

\section{QUESTIONS.}

1. What is the difference between the Pavia or Buckeye, and the common Horse Chestnut? 2. What plant is linen made from, and what coloured flowers has it? 3. Where is flax most grown? 4. What part of the plant is the linen thread made of ? 5. What is linseed? 6. What coloured flowers has the Cotton Plant, and where 
does it grow? 7. What part of the plant is the cotton made from? 8. To what natural order does the Cotton Plant belong? 9. What tree are the Russian bast mats made from, and what part of the tree are they? 10. Where do what are called China Oranges grow? 11. Why does the Spindle Tree take that name? 12. What is a rosary?

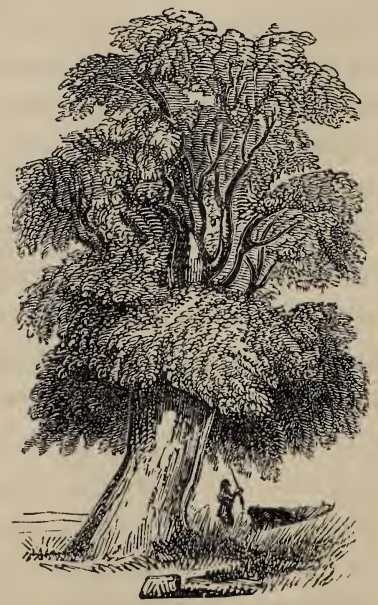

MAHOGANY-TREE. 


\section{CHAP. XIV.}

THE BOX TREE. OTHER PLANTS BELONGING TO THE ORDER EUPHORBIACEE. CASTOR OIL PLANT. BRAZILIAN INDIAN RUBBER TREE. CALANDRINIA. PINKS AND CARNATIONS. OTHER PLANTS OF THE NATURAL ORDER SILENACEE. THE TAMARISK TREE. THE RUE TRIBE. THE GERANIUM TRIBE. THE BALSAM TRIBE. THE GARDEN NASTURTIUM. THE WOOD SORREL TRIBE.

THE BOX TREE.

THE Box tree (Buxus sempervirens) is a bushy evergreen tree, with small shining leathery leaves, and still smaller flowers. In many parts of Europe, the tree box has been known to grow thirty feet high, with a trunk a foot in diameter. The dwarf box which is used for making edgings to the walks in gardens, is a variety of the tree kind.

The box grows naturally on Boxhill near Dorking, and also in several hilly and mountainous parts of France; but it is most abundant in Turkey, Persia, Circassia, and Georgia. Almost all the box used in wood engravings comes from Turkey, but a great part 
of it is grown in Circassia and Georgia. You know what wood engravings are; they are pictures carved in wood, and then blacked over and printed like letters. Well, the only wood used for these is the box, on account of its hardness, and the closeness of its grain. A large box tree is cut down, and its trunk sent to England, or France, or wherever it may be wanted by the wood engraver; it is then cut in slices, each the thickness of the tree, and these, when smoothed and polished, are called blocks, and are ready for engraving on.

Before the engraver begins his work, an artist is employed to draw the design, who first rubs the smooth surface of the block over with flake white mixed with water, to enable him to draw upon it with a black-lead pencil. He then draws the design very carefully, and with very distinct lines; and then the engraver begins to cut the block with a sharp tool like a little chisel; cutting away the parts that are to be left white, and leaving the parts that are to make black lines on the paper, so that they may receive the ink. Sometimes the same person both draws and engraves. A great many tools, like little chisels, are wanting of different degrees of fineness for wood engraving; and it is an art that requires 
not only great skill, but great patience to execute it well.

The box tree was a great favourite with the ancient Romans, who used to cut it into a great variety of forms. The art of doing this was called topiary; and figures of box were so common in all the gardens of Rome, that at last the common name for a gardener came to be toparius, signifying one who could cut trees into a variety of shapes. When trees were to be clipped into odd shapes, a frame work of wire, of the desired shape, was put over the whole tree, and the parts that projected beyond it were clipped off. The Romans also planted the dwarf box in lines, so as to form letters and words. This practice is continued in Rome to the present day ; and in the garden of the Vatican the name of the Pope who laid it out, with the date of his election, may be read in letters of box.

OTHER PLANTS BELONGING TO THE ORDER EUPHORBIACE无.

You will be surprised to hear that the little weedlike plant which you may have seen in cottage gardens, with yellowish green roundish leaves, and which is called Caper Spurge, because its flower buds 
are sometimes pickled and used instead of capers, belongs to the same natural order as the box. When the spurge is broken, a milky juice issues from the wound, which is very acrid, and would blister a delicate skin, and its seeds yield an oil which is violently purgative. You will not be able at first sight to find any points of resemblance between this little plant and the box tree, for the principal characteristics of the order lie in the flowers and the seeds. In the flowers of the box tree some contain only stamens, and the others only pistils, the latter only producing fruit; and the seed vessel, or fruit, as it is botanically called, is always divided into three distinct cells, each containing one seed or two seeds so fitted together as to look at first sight like one; and this is the case with all the kinds of euphorbia. There are also some points of resemblance in the qualities of the plants belonging to Euphorbiaceæ. They are all more or less purgative, and many of them are poisonous; even the leaves of the common box are said to be poisonous to animals if they eat them. All these plants also contain more or less of an acrid milky juice when broken.

There are many other kinds of euphorbia; from some of which is made the drug euphorbium, which 
is a violent poison, even the dust from it, if swallowed, occasioning delirium and stupor; and the Medusa's Head (Euphorbia Caput Medusæ), which is a native of Teneriffe, and which looks like a great melocactus hung round with serpents.

The Castor Oil plant (Ricinus communis), the Palma Christi of the gardens, also belongs to this order. It is a native of Europe, and of the East and West Indies. The greatest quantity of the oil used as medicine is sent from the East Indies, and particularly from Ceylon. The best oil is pressed from the seeds of the plant by grinding and pressing them as the seeds of the poppy are ground and pressed for poppy oil ; but an inferior kind is made by boiling the crushed seeds in a linen bag, and skimming off the oil as it rises to the surface of the water. These seeds are as large as small kidney beans, and are shining, and very beautifully marked. Castor oil is also made from the seeds of these plants grown in France and Spain.

In Europe the Palma Christi is an annual, or at least a biennial; that is, the same plant never lasts longer than two years; but in hot countries it lasts several years, and almost becomes a tree. It is a tall growing plant with large leaves, very strongly marked 
with purple veins on the back. The flowers are produced in clusters, and are greenish.

The Croton oil is produced from the seeds of another plant belonging to this order (Croton Tiglin). This plant is a native of the East Indies, where it grows to the size of a tree. The flowers are of a greenish white, and grow in long spikes; the leaves are large and pointed; and the fruit, or seed vessel, which is the size of a hazel nut, is like all the euphorbiaceæ divided into three cells with a large seed in each. The oil made from these seeds is so powerful in its effects, that one drop is a dose. There is a species of Croton common in the English hothouses, the leaves of which appear to be painted. This kind is called Croton picta.

The Cassava or Manioc (Jatropha Manihot) is a native of the West Indies, and also of Asia and Africa. It is a crooked branched shrub, with deeply cut leaves, and loose racemes of small yellowish or reddish flowers. The fruit is round, and consists of three cells, each containing a shining seed about as large as that of the castor oil plant. The roots are very large and thick; they are as big as what are called yams, which you may have seen in the orange merchants' shops. Every part of the plant is filled 
with a poisonous juice, and yet from the roots the ingenuity of man has contrived to extract wholesome and nutritious food. The roots are first scraped or grated, or ground in a kind of mill; and the pulp thus formed is kept for several hours under a very heavy press. By this means all the poisonous juice is pressed out, and the remainder which looks something like the floury part of mealy potatoes, but more fibrous, is ground into flour. Of this flour bread is made, which is commonly used in the West Indies instead of bread made of wheat.

Many other kinds of food are made from the cassava, but that best known in Europe is the tapioca; which no doubt you have tasted. It is made from the floury part of the cassava root, after it has been scraped and pressed; and this flour is well worked with the hands to separate it from the fibrous part of the root. It is then put into water and well stirred about. It is afterwards left to settle; and when the flour has all sunk to the bottom, the water is poured off, and the sediment placed over a very slow charcoal fire to evaporate the remaining moisture. While this is doing it is continually stirred, and this stirring forms it into the grains in which it appears when sold in the shops. 
There are many other curious plants belonging to the order euphorbiaceæ; such as the Manchineel, which is said to poison any one who sleeps under its shade, and the Excæcaria, the juice of which produces blindness, but I shall only tell you about one more, and that is the Siphonia elastica, which is one of the trees, the milky juice of which produces the Indian rubber.

The caoutchouc or Indian rubber is made from eight or ten different trees in different parts of the world; in fact all the plants which have a milky juice produce it in a greater or less degree. The Indian rubber used in England is nearly all sent from Brazil, and is the dried juice of the Siphonia or Hevea elastica, called Hhevé by the natives. This tree was first discovered in 1735 , by $\mathbf{M}$. de la Condamine when he visited Brazil in that year; though Indian rubber, made from other trees, that I shall tell you about presently, had been introduced, and in common use in Europe long before that period. Indian rubber is still made from several trees in India, and other countries; but the largest quantity of that used for making waterproof clothes is imported from Brazil, and is the produce of the Siphonia elastica.

To produce the caoutchouc, the trees are bored in 
the rainy season, when a thick yellowish white juice exudes, which turns black by exposure to the air. While in a fluid state it may be made to take any form required by spreading successive layers of it over models of clay. That sent to England is generally in the form of a bottle, and small pieces of the clay that served as a model may often be found inside. While the substance is still soft, various lines are drawn upon it with some kind of sharp instrument, which remain on it, when it is become dry and hard.

A method has lately been discovered of dissolving caoutchouc, and applying it to any article which it may be wished to render waterproof. To make this waterproof cloth, the Indian rubber is dissolved in the oil distilled from gas tar, and then spread over the surface of a piece of cloth, on which another piece of cloth is laid, and the whole pressed together by passing the layers between a pair of rollers. The Macintoshes and other articles made of this cloth are perfectly waterproof. The French call Indian rubber gumme elastique; and the name is a very good one; for the juice it is made from is a kind of gum, and nothing can be more elastic than Indian rubber. If you break a little bit off a piece and twist it up, you will see it jump and untwist itself; its elasticity 
prompts it to collapse, and it cannot do this till it is untwisted.

THE CALANDRINIA.

Let us now take a walk round my garden; I have some flowers to show you; and here is one of the most beautiful. Look at it! What a delicate rosecolour its flowers are, and how curiously its buds are speckled! Now touch the leaf. You are surprised to find how thick and succulent it is. I believe I explained the meaning of the word succulent to you before, and this quality in the leaves is one of the characteristics which distinguish the order Portulaceæ, to which this plant belongs. It is called Calandrinia Discolor,

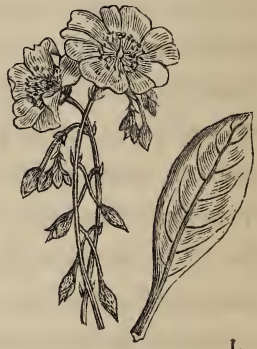

CALANDRINIA DISCOLOK. and it only expands in bright sunshine.

There is another kind, called Calandrinia Speciosa, which has bright dark scarlet flowers, that lie on the ground, half buried in a thick bed of leaves, with their petals closed all night, as if fast asleep, but in the morning, when the sun rises, one by one they open their dark eyes, as if rejoicing in its beams. In 
the evening, as soon as the sun ceases to shine on their bed, they shut themselves up again, and go to sleep.

The common Purslane (Portulaca sativa) belongs to the same order. The leaves are small and almost round, and the flowers are like little stars.

\section{PINKS AND CARNATIONS.}

I am now going to tell you about some of the prettiest flowers in our gardens, and some that I think you are very fond of. I allude to the Pinks (Dianthus plumarius) and the Carnations (Dianthus caryophyllus). The carnation being the oldest flower, I mean that which has been longest in cultivation, I will begin with it, and tell you all I know of its history.

You will be surprised to hear that the carnation is sometimes found wild in England, and that it even grows in abundance on the old walls of Rochester castle, and other ancient buildings. You must not, suppose, however, that this wild flower is quite so beautiful as the carnations of our gardens; on the contrary, it is a single flower, that if you have seen it, you have no doubt mistaken for a wild pink.

There are several sorts of carnations. There are 
the Cloves, which smell like a clove, and which are generally all of one colour, a deep red. There are the Flakes, which are of two colours, in broad stripes down each petal; and the Bizarres, which have never less than three colours, and are marked irregularly with numerous narrow stripes and spots. The picottees are generally smaller than the carnations, and the ground of their petals is white, with

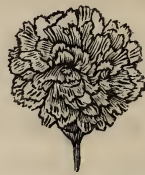

PICOTTEE.

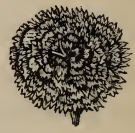

L.

PINK. a narrow margin of some dark colour, and generally some very small spots on the other part. Picottee means dotted. Scarlet, purple, and pink are the colours of the carnations, on a white or yellow ground; and the flowers are valued according to the clearness of their colours and the distinctness of their marks.

It is not exactly known of what country the pink is a native, but it is supposed to be of some part of Europe. The flowers are more fringed than those of the carnation. I do not know the exact marks of distinction which florists have for the different kinds of pinks, but I know that the most beautiful are called Laced Pinks. 
Pinks are more common than carnations, because they are more easily grown, but both require some care. Carnations are very apt to burst in the bud, and then the flower is spoiled, as the petals come out all on one side; so that florists who are very particular tie a thread round the bud, and put a circle of curiously cut pasteboard round it, to keep the flower together when it expands. They are both increased by what are called pipings, that is, cuttings of the tips of the shoots.

The Chinese Pink (Dianthus chinensis) is an annual or biennial pink, so that if you sow the seeds of it in your little garden, you will have plenty of pinks of all shades of red, purple, and white ; for in a large bed, you will hardly find any two alike.

There are several kinds of dianthus which grow wild in England; and one of these (Dianthus armeria) is called the Deptford Pink, because great numbers of it were formerly found near Deptford. There is scarcely any county in England in which you will find more beautiful wild flowers than in Kent. The soil is generally dry and chalky, and the flowers seem to like to grow in it.

You know the Sweet William? Yes, but I do not think that you know that it belongs to the same 
genus as the pink. It does, and its botanic name is Dianthus barbatus, or the Bearded Pink, or Divine Flower; for that is the literal English of dianthus. The Sweet William is not a native of England, but was brought here from the south of France, nearly three hundred years ago. I do not know why it was called sweet William. The Mule Pink is a hybrid between this and the carnation.

OTHER PLANTS BELONGING TO THE NATURAL ORDER SILENACEÆ.

The Soapwort (Saponaria officinalis) is a pretty little flower, like what you might fancy a doll's pink. It grows best on rockwork or in pots, as it is a terrible thing for spreading, and its roots creep under the ground like those of couch grass. The leaves of the soapwort form a lather like soap, and will take out spots of grease. So the plant is called soapwort.

Have you ever seen Lobel's Catchfly (Silene armeria)? It is a common annual flower in our gardens, and it is rather pretty. The name of catchfly alludes to a gummy sort of moisture on the stems, to which small flies stick when they fly against it. There is another kind of silene, called the Bladder Catchfly, 
or Bladder Campion (Silene inflator), the flower buds of which puff out, as if they thought themselves too great to let the leaves approach them. The leaves of this kind, when boiled, are good to eat, and taste like peas. In 1685, the inhabitants of Minorca, after a swarm of locusts had destroyed all their common vegetables, saved themselves from famine by eating this plant, the glutinous property of which had frightened the locusts, and prevented them from attacking it.

The Scarlet Lychnis (Lychnis Chalcedonica), the Corn Cockle (Agrostemma Githago), and the Rose Campion (Lychnis flos Jovis), all very showy and well known flowers, belong to this order, as do the Ragged Robin of the hedges (Lychnis flos cuculis), the Red Batchelor's Buttons (Agrostemma sylvestris), the Purple Sandwort (Arenaria rubra), and many others.

One of the plants belonging to this order is the common Chickweed (Stellaria, or Alsine, media), the seeds of which little birds are so fond of. This plant, common as it is, has several curious things about it. The flowers open every day, when the sun shines, about nine o'clock in the morning, and continue open till 12 at noon, when they close. When they first 
expand, their footstalks stand quite erect; but when the flowers fade, the footstalks hang down, as though ashamed of their burden, till the seeds ripen, when they stand up again, as though to show that they have something to be proud of. In rainy weather the flowers do not open, and the stalks hang down all day. The chickweed also is a remarkable instance of the sleep of plants. At night the leaves approach in pairs, so as to enclose the tender buds; those nearest to the bud first wrap themselves round it, and then the two next below, which are furnished with longer stalks, in order that they may reach the bud, and lend their aid in folding round it, and in protecting the tender end of the shoot.

Thus wonderfully and beautifully has the Great Creator provided for the protection of this trifling weed! Almost every plant I have mentioned shows similar instances of His kindness, forethought, and power; but as it would confuse you and take too long for to tell you all, I only repeat to you some of the most striking.

THE TAMARISK.

Now come into the garden, for I want to tell you about the common rue; but look as we go along at 
that tree with such light feathery foliage. That is the French Tamarisk (Tamarix gallica); but it does not thrive well in my garden; it likes the sea side, and it will stand the sea breeze better than any other tree that I know. The tamarisk belongs to the natural order Tamariscenæ.

The Rue Tribe (Rutacece).

The common Rue (Ruta graveolens) is a plant with very bluish green or glaucous leaves and yellowish flowers, both which have a very disagreeable smell. Graveolens signifies heavy scented, and any one who has ever smelt the rue, must allow that the name is well applied. It was formerly believed that the smell of rue would drive away witches, and it was called the Herb of Grace; because it was thought that no one who wore it could be hurt by evil spirits. In Germany rue is given between two slices of bread and butter to children who have the worms, but it would be rather dangerous if taken too much of. It is also given to poultry when they have the roup ; and to dogs that have the distemper. So it is generally grown in every garden for the use that may be made of it.

The Fraxinella (Dictamnus albus) also belongs to 
the rue tribe. This plant, when rubbed, has the smell of lemon peel, and it is remarkable for a fact which the daughter of Linnæus discovered respecting it.

This young lady, going into her garden at night, to examine some plant or insect, chanced to set down a candle near the Fraxinella, when to her great surprise, she saw a flame play round the plant; she removed her candle, but still the flame was there, and it had a very singular effect in the darkness of the night. It was afterwards found that the glands of the Fraxinella are full of fragrant oil like those of the myrtle; and this oil, when the weather has been very hot and dry emits an inflammable gas, which readily takes fire and burns, without injuring the plant.

The Diosmas (also belonging to Rutaceæ) are very strong smelling plants, natives of the Cape of Good Hope ; where the Hottentot ladies use them as perfumes. If you were to stroke one with your glove on, you would not be likely to forget the smell; for you would be reminded of it every time you put on your glove, for days, nay, weeks afterwards. 


\section{The Geranium Tribe (Geraniàcece).}

Most probably the only Geranium you ever saw was the Herb Robert. I know all you are about to say about keeping geraniums in pots in windows and greenhouses; but still I repeat that I do not think you ever saw a real geranium but the one I have mentioned; though there are several other kinds of the genus to be found wild in England. You look still more and more astonished. The fact is that what are commonly called geraniums are Pelargoniums; while the real geraniums are what I have told you.

There are a great many different kinds of Pelargoniums; but most of them are hybrids raised from the seeds of the horse-shoe geranium (Pelargonium zonale), the common scarlet (Pelargonium inquinans), the hooded-leaved (Pelargonium cucullatum), the oak-leaved (Pelargonium quercifolium), and the rosescented (Pelargonium capitatum and graveolens). The species are all natives of the Cape of Good Hope; but the hybrids have been raised from seed in this country, and on the continent.

Pelargonium signifies the stork's bill; Geranium, 
the crane's bill; and Erodium the heron's bill, all the names being derived from the shape of the seed pod, which in all these genera, looks like the head and beak of a bird. Most of the kinds of Geranium and Erodium are little hardy weeds, which grow without any care in British meadows; but the Pelargoniums are all natives of the Cape of Good Hope, and will not live in the open air during winter in England. The seed pods of the whole genus when ripe, and quite dry, burst with a snapping noise, and the different divisions of each pod curl up when they have burst, and let out their seeds. The seeds themselves are often very beautiful, and curiously netted all over their surface.

\section{The Balsam Tribe (Balsaminea).}

The Balsam (Balsamina hortensis) is a very beautiful tender annual, a native of the East Indies, which was first brought to England about two hundred and fifty years ago. There are now many kinds of balsam ; most of which are what are called hybrids, and have been raised from seed in England, but some are different species, that have been introduced since the first kind was imported. The balsams are all raised from seed sown on a hot bed; and when 
the plants come up they are first put in very little pots, and then transplanted several times into larger and larger ones as they grow, till at last they are seen going into flower, after which they are not transplanted any more, but supplied with plenty of water till they expand their flowers; which, when the plants are thus treated are always very fine.

The Noli-me-tangere, or Touch-me-not (Impatiens Noli-me-tangere), belongs to the same natural order as the balsam; and they both show their relationship to the geranium tribe, by the manner in which the seed pods burst and curl up, when they discharge their seeds. Touch the seed pods of this plant, which is called Jumping Betty. It is a kind of impatiens with small flowers. There it has made you jump, though you knew what to expect. See the seeds are all gone, and the sides of the seed pod are curiously rolled up.

\section{The Nasturtium Tribe (Tropaolea).}

Now we are in the garden, I will tell about a plant, the flowers of which you know very well, and which I mentioned to you before, when I was talking of the cress. I mean the common garden Nasturtium (Tropæolum majus). The seeds of this plant when 
pickled are used as capers; and the young and tender shoots are very good to eat as salad. It is on this account as I before told you that the Tropæolum majus, is called Nasturtium, because that is the botanical name of the water cress; and because the tender shoots of this plant tasted like it, it was first called Indian cress, and afterwards nasturtium. The old English name of the flower is the yellow larkspur.

In the French work called Le Langage des Fleurs, it is said that the larkspur signifies lightness, from its brilliant yellow flower; and that it takes its name of larkspur from its seed being marked like claws. Both these circumstances show that the flower here meant.is the nasturtium; for the real larkspur never has yellow flowers, and its seeds, which are very small, and black, are quite smooth and shining.

There are several annual kinds of nasturtium, varying merely in colour, and one that is of a very dark rich brown; but there are others which are perennials, which vary in form. One of these is called Tropæolum tricolorum, and another the Canarybird flower (Tropæolum peregrinum). Both these are climbing plants, and are generally kept in the greenhouse. 


\section{The Wood Sorrel Tribé (Oxalidacece).}

Perhaps some of the prettiest flowers in English greenhouses are those called the Wood Sorrel or Oxalis. There is one kind, Oxalis crenata, the tuberous roots of which have been recommended as a substitute for potatoes; but which I think very few people would like to eat, as they are very insipid. The stems and leaves of these plants are acid.

\section{QUESTIONS.}

1. What is the wood of the Box tree used for? 2. What plant is the castor oil made from, and where is it chiefly made? 3. Is Indian rubber made from only one tree? 4. What are the principal garden flowers belonging to the Pink tribe? 5. Why is Rue grown in so many gardens? 6. What is remarkable about the Fraxinella? 7. What is the proper name of the plants usually called Geraniums? 8. In what respect do Balsams resemble geraniums?

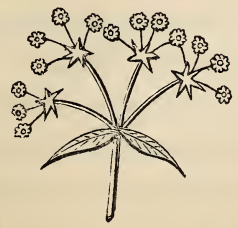




\section{CHAP. XV.}

THE ROSE TRIBE, INCLUDING ROSES, BRAMBLES, STRAWBERRIES, ETC. THE APPLE TRIBE. PEARS. THE MOUNTAIN ASH. THE WHITE BEAM TREE, THE QUINCE, AND THE MEDLAR. THE HAWTHORN. ALMONDS, PEACHES, NECTARINES, AND APRICOTS. PLUMS AND CHERRIES. THE FEAST OF THE CHERRIES AT HAMBURGH. THE COMMON AND PORTUGAL LAURELS.

\section{The Rose Tribe (Rosacea).}

THE Rose is generally called the Queen of Flowers; and it is indeed one of the most beautiful grown in our gardens, as well as one of the sweetest. I need not tell you what a rose is, but I may tell you what a great many different kinds of roses there are. There are above a hundred species; besides I do not know how many hybrids and varieties. There were above twelve hundred differently named sorts in the nursery of Messrs. Loddiges at Hackney some years ago; and I dare say there are a great many more now.

One of the best known of these roses is the common Cabbage Rose (Rosa centifolia), which is said to have a hundred petals. It is a native of Mount 
Caucasus, but it has been a long time in cultivation in our gardens. The moss rose is a variety of this kind. There is a little German poem which tells so pretty a fable about the moss rose, that I will try if I can recollect it.

The goddess of flowers was one day much fatigued and exhausted, with performing her numerous duties; and at last, quite worn out, she threw herself under the shade of a rose bush. Refreshed and invigorated by the agreeable shade of the plant, and the fragrance of its flowers, when she was about to depart she asked the rose what she should do to repay the benefit she had received. "Make me more beautiful," said the rose, who appears to have been somewhat vain. "That is almost impossible," replied Flora, who was very polite; " and indeed I can only give you a new charm, by concealing part of what you already possess." So saying, she threw a clothing of moss round the flower, and told the rose that it was an emblem of how much modesty added to beauty.

The French rose (Rosa gallica) is the one that was the badge of the House of Lancaster; and it is also the one imitated in the ornament called the rose in architecture. It is large and flat, of a beautiful deep 
rose colour with bright yellow stamens. The damask rose (Rosa damascena), sometimes called the Rose à quatre Saisons is another very beautiful rose; and it is from these three kinds that rose water, attar of roses, oil of roses, and conserve of roses are made.

The best attar of roses comes from Persia, Syria, and Cashmere. It is sometimes called otto of roses, but attar is an Arabic word, signifying perfume. It is made by steeping the petals of the rose in water, and exposing them to the heat of the sun for several days, when the oil contained in them is drawn out by the excessive heat, and floats on the surface of the water. This oil is the attar of roses.

Travellers in the east speak with great delight of the fields of roses which spread over many acres; particularly near Damascus, where the whole city is perfumed by the fragrance of the rose plantations which form a kind of belt round it. Bishop Heber tells us that there are rose fields of many hundred acres in extent round Ghazepoor in India; he adds that it takes two hundred thousand roses to make the weight of a rupee, of the pure attar, and this quantity sells for ten pounds. The pure attar is, however, generally adulterated by oil, or some similar substance before it is sent to Europe. 
Besides the roses I have already told you about, there are the double Yellow Rose (Rosa sulphurea); the Ayrshire Rose (Rosa spinosissima); the common White Rose (Rosa alba); the Sweetbrier or Eglantine (Rosa rubiginosa); the common Dogrose (Rosa canina); and many others. Perhaps the most beautiful of the genus are the common China rose (Rosa indica), and its varieties, the Noisette and the tea-scented roses. Then there is the dark crimson China Rose (Rosa semperflorens); the Fairy Rose (Rosa Lawrenceana); and the Seven Sisters (Rosa Grevillei), the peculiarity of which is that the flowers are always produced in bunches of seven each, and that these are always of seven different colours, viz. white, light blush, dark blush, light crimson, dark crimson, scarlet, and purple. This rose grows very freely, and flowers abundantly, but it does not live many years.

I think now you will begin to be tired of my chapter on roses; and so I will only mention two more: viz. the Musk Rose (Rosa moschata); and the Banksian Rose (Rosa Banksia); the latter being of two kinds; one with white flowers, and the other a pale buff. 


\section{THE BRAMBLE.}

The Bramble belongs to the same natural order as the rose; and it resembles it in its flower, for the flowers of all the kinds of bramble look like little single roses. The common Blackberry (Rubus fruticosus) grows wild in the hedges, and I dare say you have often tasted its fruit, and been scratched by its thorns; for all the brambles are furnished with strong and sharp hooked prickles. The Dewberry (Rubus cæsius) is another sort of bramble; and you will perhaps be surprised to hear that the raspberry (Rubus Idæus) is another. Look however at the fruit of the raspberry and that of the blackberry, and you will see that they are very much alike; and the flowers are still more so. The wild raspberries which grow in the woods are much smaller, and more acid than those grown in the gardens.

The raspberry is what is called a travelling plant; that is, the same stalks do not produce fruit above three or four years in succession, but before the stalks die down they send up others to supply their place beside them; these in their turn send up others a little farther on; and in this way, a raspberry, if left to itself, would in time travel across a small garden. 
The gardeners however every two or three years take up the suckers, and make a fresh plantation with them.

THE STRAWBERRY.

After the raspberry what can come more naturally than the Strawberry. We always class them together in our gardens and at our tables; and modern botanists also class them together in their systems. The Strawberry (Fragaria vesca) has been called a berry with its seeds on the outside; but the fact is, that these little things that look like seeds are seed pods or capsules, each of which has a seed inside. There are a great many kinds of strawberry. The wild strawberry of the woods is very small, it is of a dark scarlet, and it has a very fine flavour. The Alpine strawberry greatly resembles it; and this kind is in great favour on the continent, particularly in Holland, where they never think of giving you a breakfast in the strawberry season, without a large plateful of that fruit.

The principal other kinds of strawberry are Keen's Seedling, which is the best for general use ; the old Pine, which has a fine flavour but does not bear well; the Hautbois, which has a still higher flavour, and is 
a still worse bearer ; the Green Strawberry, the fruit of which, even when ripe, never becomes red; the Scarlet, which is generally used for ice cream, on account of its beautiful colour; and lastly, Wilmot's Superb, which has not much flavour, but has been grown so large, that a lady is said to have asked for a slice of one, thinking it too big to venture on a whole strawberry at once. The strawberries which are generally sold in the streets, and called fine Hautbois, are of the sort called Keen's seedling.

OTHER PLANTS BELONGING TO ROSACEÆ.

The Potentilla and the Geum, two very beautiful flowers, belong to this order; and there are many varieties of both, particularly of the former, all so beautiful, that it is very hard to say which is the best. The double yellow Corchorus, now called Kerria japonica, that beautiful plant, which we so often see trained against the walls of cottages, also belongs to it. It is a curious fact that though the double variety of this plant has been in England ever since the year 1700 , the single flowered plant or species was not introduced till 1836. The Japanese, of whose country it is a native, do not like strangers, and most of the plants which we have obtained from 
Japan have been had through the medium of the Chinese.

The Spiræa is a very beautiful genus. These plants are shrubs with very small and elegant flowers clustered together in spikes or heads. One of these (Spiræa salicifolia), commonly called Bridewort, or Queen's Needlework, is a native of Siberia, from which country it was introduced nearly two hundred years ago. Another kind, Spiræa bella, which has beautiful heads of pink flowers, is a native of Nepal, and was introduced in 1820; while another (Spiræ aerifolia), still more beautiful, from its light feathery white flowers, is a native of North America, and was introduced in 1827. There are a great many other kinds of Spiræa; but these will be enough to give you an idea of the genus.

\section{THE APPLE TRIBE.}

The Apple (Pyrus Malus) is one of the most useful fruits we have. Besides being very good to eat raw, or made into pies and puddings, it is used to make cider; which may be called apple wine, since it is made of the juice of the apple after it has been ground and pressed, in the same way as port and sherry, and other foreign wines, are made from 
the juice of the grape. In France, they make a kind of jam called raisiné, of apples boiled down with new wine; and this raisiné the French children eat spread on bread, in the same way as English children eat raspberry jam.

The Crab is the wild apple, and from its juice that very strong vinegar called verjuice is made. The word pomeatum comes from the apple; for in Queen Elizabeth's time, when pomeatum was first invented, it was made of the pulp of apples beaten up with lard and rose water.

The apple, in a botanical point of view, is formed like the plants belonging to the myrtle tribe, by the swelling of the lower part of the tube of the calyx, while the upper part remains on like the crown of the pomegranate, and forms the eye of the apple. This is the case with all the Rosacea, and you will find it in the hips and haws of the hedges; the one being the fruit of the wild rose, and the other of the hawthorn, both of which plants belong to the same natural order. Now, when you next see an apple or a pear, you will remember that what is called the eye is in fact the remains of the calyx. The apple blossom is like a single rose, and it is very beautiful. The seeds are the kernels; and they are found in a cavity 
in the heart of the apple, protected by that curious substance that we call the core.

If I were to attempt to tell you all the different kinds of apples, I should soon tire you, and you would not remember half of them, so instead, I will repeat to you the song the farmers in Devonshire sing to their apple trees, on Christmas eve.

Here's to thee, old Apple Tree,

Long may'st thou bud, and long may'st thon blow,

And long may'st thou bear good apples enow.

Hats full! caps full!

Bushels full! sacks full!

And my pockets full too.

Huzza! Huzza!!

The Pear (Pyrus communis) is not quite so useful as the apple, because it does not make such good pies and puddings, but perry is made of it, which may be called pear wine. Pears are very good stewed; and there are some little boxes, which I have seen in the grocer's shops, full of pears dried in France in such a way as to be very nice.

There are a great many kinds of pear; but the best are those called the Flemish pears, most of which were raised from seed by Professor Van Mons of Brussels. 
I must not quit the apples and pears without telling you about the Sand Pear (Pyrus sinensis), which is a native of China, and which is so gritty, that when you eat it you seem to have your mouth full of sand. I must also mention the Woolly Pear tree (Pyrus crenata), a native of Nepal, the leaves of which look quite white, and feel soft and downy to the touch, from their thick covering of wool; the Siberian Crab (Pyrus baccata), so well known for its beautiful little red and yellow fruit; which look like gigantic cherries on the tree, and which make so delicious a sweetmeat when preserved in apple jelly; the Transparent Crab, or Astrachan Apple (Pyrus Astracanica), which looks like golden fruit when hanging on the tree; and the Chinese Crab (Pyrus spectabilis), the flowers of which are more beautiful than those of any other of the apple tribe.

The Mountain Ash (Pyrus aucuparia) is another well known tree belonging to this genus. It is very common in Scotland, where it grows on the mountain sides, and down in the deep ravines, where no mortal foot has ever trodden. Its red berries are very ornamental. The Scotch call this tree the Rowan tree, and believe that witches have no power where there is rowan tree wood. In Yorkshire they call it wiggin, 
and Mr. Waterton, a gentleman who has written some very delightful books about birds and other animals, tells a curious story about this tree in his Essays on Natural History.

THE WHITE BEAM TREE, THE QUINCE, AND THE MEDLAR.

The White Beam tree (Pyrus Aria) is one of the most prudent trees we have. It waits patiently till all the other trees (except the Ash and the Mulberry) have unfolded their leaves; and then, when all danger from spring frosts appears to be gone by, it slowly opens its buds. When the leaves unfold, they appear to be still prudently wrapped up to avoid danger from cold, for the under surface of the leaf is covered with a thick down, from which the tree takes its name. It is a native of Britain, and its berries, which resemble those of the mountain ash, are much liked by birds.

The wild Service (Pyrus torminalis), the American Service (Pyrus Americana), with its purple berries; and the True Service or Sorb tree (Pyrus Sorbus) are trees, all of which bear more or less resemblance, either in leaves or fruits, to the white beam tree, or the mountain ash. The fruit of the sorb tree is 
eaten at dessert, when half decayed, like medlars, and it has nearly the same taste.

The Quince tree (Cydonia vulgaris) is well known for its beautiful golden-coloured fruit; which, however, is not good to eat raw, though it gives an agreeable flavour to apple pies, and makes a delicious marmalade. It was found originally near the city of Cydon in Crete; but it now grows wild in the south of France, and in Germany on the banks of the Danube. There is another kind of Quince (Cydonia Sinensis), which is a native of China; but the most beautiful of all the genus is the bright scarlet flowered shrub, which used to be called Pyrus japonica; but which is now discovered to be a kind of quince, and is named Cydonia japonica. It is a native of Japan, and was introduced in 1815; and it is so hardy that it lived uninjured through all the dreadful winter of 1837-8, which killed so many plants. The Pyrus or Cydonia japonica, in mild winters, continues in flower all the year, and makes the garden gay with its bright scarlet flowers.

The Medlar (Mespilus germanica) is a tree that grows wild in England, and has been in cultivation in British gardens ever since the British had gardens. The fruit is not eaten till it is beginning to decay. 
There is only one kind of Medlar properly so called, though there is a tree that used to be considered a kind of medlar (Eriobotrya or Mespilus japonica), the Loquat Tree. This tree is a native of Japan, and though it requires a hot climate to ripen its fruit, it is grown in many countries for its large handsome leaves.

THE HAWTHORN.

What a number of agreeable ideas are excited by the very name of the Hawthorn! The sweet-smelling May, the breath of spring, the fields green with long grass, the trees covered with their young and tender foliage, are all associated with the idea of this plant. It seems almost unnatural to break through the veil which poetical recollections have thrown round the hawthorn, to tell you of its botanical name, and to describe it like other trees, yet I know not why I should hesitate to do so. The common Hawthorn (Cratægus oxyacantha) is a low tree, with small shining leaves, numerous thorns, sweet smelling flowers, and small red apple-like fruit. You laugh to hear me call the haws apples, yet apples they are, though certainly very small ones. It is true the seeds in the centre seem stones instead of kernels; 
but the fact is, they only differ in the lining of the cavities for their seeds, being bony instead of thin and papery. The construction of the flowers of the apple and the hawthorn are just the same, and the calyx remains on the ripe fruit in the same manner in both.

There are a great many varieties of Cratægus oxyacantha; some have red haws, which is the common colour; in others they are black, or dark purple, and in others yellow. The flowers of one kind are double, and these are very beautiful, for when they come out they look like little white roses, or clusters of the double flowered cherry; and when they have been out a fortnight or three weeks, they turn of a most beautiful pink.

There are also hawthorns with pink single flowers, with single scarlet flowers, and with double scarlet flowers. Then there are some varieties which grow straight up like Lombardy poplars, and others that have gracefully drooping branches like a weeping willow. One of this kind near Edinburgh is said to be the very tree under which the unfortunate Mary Queen of Scots plighted her faith to Darnley. The most remarkable of all the hawthorns is, however, the Glastonbury thorn, and this is so peculiar in its 
habits, that I must tell you what is said to be its history.

The Glastonbury thorn does not blossom at the same time as other hawthorns, but at Christmas; and I have seen a sprig of it gathered on Christmas day, which had on it at the same time ripe fruit and flowers. The legend relating to it is, that Joseph of Arimathea, when he came to England to found the first Christian church, struck his staff into the ground at Glastonbury, and it instantly took root, and shot forth into leaves and flowers. On this spot the Abbey of Glastonbury was founded; and there is within its precincts an old hawthorn tree, which produces its blossoms in winter instead of summer, and young plants from which have been spread all over the kingdom.

There are many other kinds of thorns besides the hawthorn and its varieties. There is one with large bright scarlet fruit, which is called Cratægus coccinea; and another (Cratægus punctata), the fruit of which is covered with little dots. The Cockspur Thorn (Cratægus crus-galli), has very long strong thorns. There is a dwarf variety of this tree, which grows about five feet high. Here it is, with a little girl and her dog standing under its shade. See what 
a nice little tree it would make for you to put in your own garden.

I should tire you if I were to tell you of all the thorns, so I shall only mention two or three more, the fruit of which is good to eat. The Azarole Thorn is a

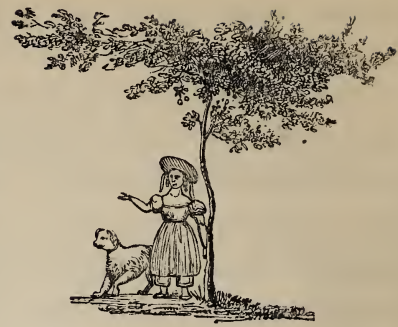

DWARF COCKSPUR THORN.

large handsome tree, with yellowish fruit. The Aronia Thorn has yellow fruit, like little apples, which are delicious to eat, and which make very nice tarts; and the Eastern Sweet-scented Thorn has large fruit of a beautiful coral colour, and whitish green leaves. There is another kind also with whitish green leaves, which has large yellow fruit, remarkable for having what are called the bracteal leaves growing to the fruit.

The Pyracantha is the last thorn that I shall tell you about. It has evergreen leaves, and bright scarlet berries that the birds are very fond of. I have one of these plants trained against the veranda round my cottage, and there is a thrush in my garden that knows it well. I never saw a bird eat like that 
thrush. I counted twenty berries that he took one after the other; and at last he seemed to go away rather because I frightened him by moving, than because he had done eating.

The Cotoneaster and the Amelanchier both belong to this order; and there are many kinds of both genera. The cotoneasters have all white flowers and red berries; and the amelanchiers have all white flowers and black berries. One kind, the Snowy Mespilus (Amelanchier botryapium), comes into flowers early in spring, and it is covered with a sheet of blossoms. Its berries ripen before any others, and they are very good to eat. The leaves of this tree become of a beautiful deep red in autumn. The Arbutus-leaved Aronia (Pyrus or Mespilus arbutifolia) is a very pretty little shrub, which is covered with white flowers in summer, and with purple or red berries in autumn.

THE ALMOND TRIBE.

All the plants belonging to this division of the Rosacea abound in prussic acid, and from the leaves of some of them a strong poison may be distilled; and yet some of our most delicious fruits are among 
them : the plum, the cherry, the apricot, the almond, the peach, and the nectarine.

The common Almond (Amygdalus communis) contains, as no doubt you well know, a very sweet kernel, which is very good to eat with raisins at the dessert, and which, covered with sugar, makes a very nice sugar plum. All this you know ; but very likely you do not know that the fruit of which this is the kernel, is a hard dry kind of peach, all skin and stone. The thick downy skin is taken off, and the stone it contains cracked. The kernel is then found within, enveloped in an aril or thick wrinkled skin, which is very unwholesome, and which is, therefore, generally taken off the almonds before they are eaten. This is done by steeping the kernels in hot water, when in a few minutes the hard thick skin shrivels up, and the white kernel is easily slipped out.

The almond tree is one of those few trees which come into flower before they come into leaf; and its beautiful large pink blossoms look very beautiful indeed, because they come out when nearly all the trees around them are bare of their leaves.

The peach and the nectarine are only two different species of the same genus, and they have been some- 
times found growing on the same tree. The Peach (Persica vulgaris) is downy, and the Nectarine (Per sica lævis) is smooth. This is all the difference, for the flowers are so much alike that you would not know them apart. A fruit has been found which was half smooth skinned and half downy, so that it was both a nectarine and a peach.

Some of these fruits are called clingstones, and these you have hard work to separate from the stone; and others freestones, and these separate from the stone without any difficulty. You must have seen both kinds. There is a double blossomed peach tree, which is very beautiful when covered with its delicate pink flowers, but which does not bear any fruit.

The Apricot (Armeniaca vulgaris) has white flowers, and its fruit is covered with a downy skin like the peach. This tree is a native of Armenia, and other nations of the east. It was introduced into England by the Romans, and is now grown in almost every fruit garden.

THE PLUM TREE.

There are a great many different kinds of plum tree; but as there are only two plums which grow 
wild in England, I will begin with one of them. This tree is generally called the Blackthorn or Sloe. You laugh at my calling the sloe a plum, but it is one, though certainly, I confess, not one of the most agreeable to eat. However, it is at any rate as good as the English native apple, the crab ; and you must remember that all these improved sorts, which are so much more agreeable to the palate, are the effects of cultivation.

The sloe is called in France the mother of the woods; because it sends up so many suckers, that in a short time, if left to itself, it will cover a tolerably large piece of ground with thicket; and this is the reason that the farmers in England do not like to see sloe trees in their hedges. The botanical name of the sloe is Prunus Spinosa, which means the Spiny Plum Tree.

The Bullace (Prunus insititia) is another kind of wild plum; but the plum cultivated in our gardens is called Prunus domestica, and all the different sorts, such as the Green Gage, the Orleans, the Magnum Bonum, \&c. are only varieties of it.

You know, I suppose, that prunes are dried plums. The French plums and prunes are first dried in the sun, and then in the oven, putting them in and taking 
them out again several times till they are quite dry. In some cases the operator turns the stone in the plum round, without breaking the skin, and presses the two ends of the plum together, so as to make it quite round instead of oval. This, however, is only done with the finer kinds that are to be packed in boxes.

The Brignole plums are peeled before they are dried, by women, who only use their thumb nails for the operation, as any kind of iron or steel knife would injure the delicate colour and transparency of the fruit. They are then stuck on little rods, so as not to touch each other, and hung up to dry. The stones are afterwards taken out by hand, and the plums pressed together, so as to make them quite round; after which they are packed in boxes for sale. It is a curious fact, that these plums were prepared in the time of Henry IV. of France, about 1597, in exactly the same way as they are now.

\section{THE CHERRY TREE.}

There are two distinct kinds of wild Cherry. One (Cerasus sylvestris), a little black cherry, called the Gean in Scotland, and the Merries in Suffolk, from which all the Bigarreau or hard-fleshed cherries are 
descended; and the other (Cerasus vulgaris), the Kentish or Flemish Cherry, from which all the May Dukes, Morellos, and all the soft-fleshed juicy cherries have originated. All the hard-fleshed cherries are more or less bitter, and all the soft-fleshed kinds are more or less sour. Of all the first kind the Bigarreau is the best, and of the latter, I think the May Duke. You will perhaps think that this name signifies that the cherry ripens in May; but the fact is, that May Duke is a corruption of Medoc, the province of France where the variety was first raised. The word Merries is also a corruption of the French word Meriser, which is derived from the words amère, bitter, and cerise, cherry.

Cherries are said to have been first brought to England by the Romans, and to have been introduced into Italy by Lucullus a Roman general who lived 68 в. с., and who brought the tree from Cerasus in Asia. This may be true of the juicy acid cherries; but the hard-fleshed bitter kinds are found wild in Italy, France, and even England. In some parts of France, the poor people live in a great measure on the fruit of the wild cherry; which they dry in order to keep it during winter. Soup made of these dried cherries, with a little bread, and a little butter, is the 
common nourishment of the wood cutters and charcoal burners in the forest during winter.

The strong spirit which the Germans call kirschwasser, and which tastes something like whiskey, is made of the little black wild cherry; as is the liqueur called moraschino. The cherries are crushed and fermented and then distilled alone to make the kirschwasser; but the mass of crushed cherries is mixed with honey before it is distilled to make the moraschino.

Now I am talking about cherries I must tell you a little tale that I heard when I was at Hamburgh. A great many years ago that city was besieged by a powerful army, and the citizens, finding that they could not defend themselves much longer, began to consult what they should do to save their wives and children from destruction. "We can die ourselves," said they, "but it will be dreadful to see these little innocent ones perish; and when the soldiers take the town, they will all be murdered." No one, however, could devise any plan to save them, and the council separated, each returning sadly to his dwelling.

When the chief burgomaster reached his own house, he was so oppressed with grief, that he could not help speaking of what had passed to his wife 
and children. They listened with deep attention, and remained in silence for some time, till at last, his youngest daughter, whose name was Agnes, and who was a little girl about seven years old, said "Let us go to the soldiers, papa, and beg them to save our lives."

The burgomaster was struck with this idea, which he regarded as an inspiration from Heaven. He sent to re-assemble the chief citizens, and going to the council with his little daughter in his hand, he told them what she had suggested. They received the idea with shouts of applause, and it was determined to act upon it immediately. Accordingly all the children in the city between the ages of five and ten were collected; and a parley having been sounded, they advanced with Agnes at their head.

The soldiers in the enemy's camp were astonished at this procession, and ran into the tents to call their officers to look at this novel sight. In the mean time the children advanced singing their evening hymn, and recommending themselves to the protection of God; the least following close behind Agnes, and the older ones ranked according to their age and size. When they reached the camp, Agnes stepped forward, and said, "We come to ask you to spare 
our lives, and those of our fathers and mothers." They had told her to say mothers only, but she could not help putting in her father too.

The officers and soldiers were many of them husbands and fathers; and those who were not, thought of their mothers and sisters; when they saw these poor helpless little children, fearless from their very helplessness, they were strongly affected, and some of them burst into tears. "Let us spare them! Let us save the city!" cried they all, with one voice; and while the general sent a herald to declare that he would spare the city, if the soldiers who had defended it, would yield themselves prisoners of war, his own soldiers ran into a neighbouring cherry orchard, and tore down boughs of cherries which they gave the children to carry home with them. Agnes felt so grateful, that she went up to the general, and thanking him in her own simple words, she put up her little mouth to kiss him for saving her father and mother; and the general, stern man that he was, felt the tears roll down his weather-beaten cheeks, at the innocence and simplicity of the child. The children then returned to the city, laden with their cherry boughs, which they carried in their 
hands, and singing a hymn of thanksgiving and praise.

In memory of this story the people at Hamburg used to hold a festival every year, called " the Feast of the Cherries ;" during which a number of children walked in procession through the city, carrying boughs in their hands, ornamented with cherries; and for aught I know, to the contrary, the same festival is continued now.

The Allsaints Cherry (Cerasus semperflorens), which has drooping branches; the Ground Cherry (Cerasus Chamæcerasus) which never grows higher than two or three feet; the Choke Cherry (Cerasus borealis), the fruit of which is so hard and dry it almost chokes those who attempt to eat it, and the black Carolina Cherry tree (Cerasus or Prunus nigra) are all common in English gardens. You must not suppose that the latter kind has black flowers, or black fruit, the fact is it takes its name from its bark; and its fruit, which is more like that of a plum than a cherry, is so much liked by birds, that it is said you are sure to have them in your garden, if you have a black Carolina cherry tree.

The double Japan cherry, generally called the 
dwarf almond in the nurseries, is a pretty little shrub with double pale pink blossoms, and the Chinese Cherry is very like it. The Perfumed Cherry (Cerasus Mahaleb) which blossoms the first in spring, and the Bird Cherry (Cerasus Padus) are very ornamental in their flowers, and the birds are very fond of their fruit. Insects are also so fond of the leaves of the bird cherry that it is said they will never touch any other tree, while there is a bird cherry left in the garden.

THE COMMON AND PORTUGAL LAURELS.

The common and Portugal Laurels are both cherry trees! that is, they both belong to the genus Cerasus. The common Laurel (Cerasus Lauro-Cerasus) was indeed formerly called the Cherry Bay, or Cherry Laurel, from the resemblance between its leaves and those of the true laurel, or sweet bay tree. It is a native of the mountains of Persia, and also of the Crimea, and when it was first sent from the latter country, to Constantinople, it was called the date or plum of Trebisond. The first laurel grown in England belonged to "Master James Cole, a merchant of London," in 1597, who planted it in the garden of his country house at Highgate, and defended it from 
"the bitterness of the wintry cold, by casting a blanket over it." From this carefully preserved tree, arose all the numerous laurels now to be found in England.

The leaves of the laurel contain a great deal of prussic acid, and thus, though one or two may be used to give a flavour to custards, puddings, \&c., they are dangerous when taken in large quantities; and the water distilled from them is a deadly poison. The Portugal Laurel (Cerasus lusitanica) is so called because it was sent to England from Portugal in 1648; though it is supposed not to be a native of Portugal, and to have been brought thither from the Azores.

\section{QUESTIONS.}

1. What are the three roses used for making rose water, \&c.? 2. What is attar of roses? 3. What other well known fruit belongs to the same genus as the blackberry? 4. What is the botanical name of the eye of the apple? 5. What is particular about the white Beam Tree? 6. What is the botanical difference between apples and haws, and in what are they alike botanically? $\quad 7$. What berries are thrushes particularly fond of ? 8 . What is the botanical difference between the peach and the nectarine? 9. What two plum trees grow wild in England? 10. What are the two great divisions of the cherries? 


\section{CHAP. XVI.}

BEANS AND PEAS. SWEET PEAS. KIDNEY BEANS. LUPINES. LABURNUM. BROOM. FALSE ACACIA OR LOCUST. GLEDITSCHIA. KENTUCKY COFFEE TREE. ACACIAS. GUM ARABIC. LIQUORICE. TAMARINDS. INDIGO. RICE PAPER. SAINTFOIN, LUCERN, AND CLOVER.

\section{The Pea and Bean Tribe (Leguminosce).}

The common Bean (Faba vulgaris) is a native of Persia, and is found wild on the banks of the Caspian Sea. I do not know when it was introduced into England, but it must have been a great many years ago, for all account of it is lost. The bean is the type of the Leguminous tribe; that is to say, all the plants belonging to that tribe are more or less like the bean in the shape of their pods, and the manner in which the seeds are placed in them. All pods formed like those of the bean are called legumes; and all the great number of plants that belong to this order or tribe agree in this one particular, however dissimilar they may be in others. There are a great many sorts of beans; such as the Broad Windsor, the 
Early Mazagan, the Horse Bean, and many others, but they are all varieties of Faba vulgaris.

The Pea (Pisum sativum) is cultivated both in gardens and fields. It is a native of the south of France; and, like the bean, it has been so long in cultivation in England, that it is not known when it was introduced. There are a great many different sorts; the earliest of which are the Warwick and the early Charlton. The Marrowfat, and Rouncival, generally grow very high, and are excellent peas to eat, and the Prussian Blue is a great bearer. But the most remarkable kind are the Sugar Peas, which the French call pois sans parchemen, which are boiled in their pods, and eaten like kidney beans. The pods of this pea are very sweet, and being without any of the thick husky skin which lines the pod of the common pea, they are very tender.

The Sweet Pea (Lathyrus odoratus) belongs to a different genus to the common eatable pea. There are six or seven different varieties, some natives of the south of Europe, some originated in England from seed, and one from Ceylon; all of which are pretty and very sweet scented. One which is half red and half white, is called the Painted Lady. The Tangier or Lord Anson's Pea (Lathyrus Tingitanus) resembles 
the sweet pea in form and colour, but it has not a sweet smell.

The Underground, or Earth Pea (Lathyrus amphicarpos), is a native of Syria, and it has pink flowers tinged with blue. In this singular plant there are underground stems, which bear flowers and pods exactly like those above ground; except that the underground stems, leaves, and flowers, are all whitish, and not so fully expanded as those which have grown in the open air.

The seeds of all the kinds of lathyrus are unwholesome, and even dangerous to eat in any quantity; and those of the Chickling Vetch (Lathyrus sativus) have the singular effect of making the muscles of those persons who eat them become rigid. About a hundred years ago, a great farnine having happened in Wirtemberg, from all the wheat being spoiled, the people made flour of the seeds of this weed, which grows wild in their country. The effects were most extraordinary; the muscles of their faces became fixed-they could neither laugh nor cry; and when they attempted to walk, they marched like wooden figures ; because, from the stiffness of their muscles, they could not bend either their ancles or their knees. In the like manner their arms and fingers became 
stiff; and when they opened and shut their mouths it was by a violent effort, which made them look like the little wooden heads used as nut crackers. These symptoms came on suddenly, and without any pain; so that the unfortunate persons were scarcely aware of their own state, till they found it out by the laughter of their companions, who in a short time, however, were afflicted in the same manner.

In consequence of the fatal effects of this meal not only upon human beings, but upon pigs, horses, and pigeons, edicts were issued by the dukes of Wirtemberg and Tuscany, forbidding the use of it ; excepting when mixed with at least double the quantity of wheat flour, when it was found not to do any harm.

The Everlasting Pea has pink flowers, and the Large-flowered Pea (Lathyrus grandiflorus) is very handsome. I was delighted with this pea when I had it first. I planted it against my trees, and I was so proud of its large beautiful flowers, that I showed them to every body who came to see me; but in a few years these peas spread so fast, that they came up all over my garden, and provoked me more than any weed.

The Tare or Vetch (Vicia sativa) is a plant that horses are very fond of when it is given to them in a 
green state, and it is a great treat for horses kept in towns, as it is an agreeable change from dry corn and hay. The Lentil (Ervum lens) will be familiar to you by name, as it is mentioned in the Holy Bible. It is not often eaten in England; but in France and Germany, people are very fond of it, and give it to their children as a very nourishing kind of food.

The Kidney Bean (Phaseolus vulgaris), which has been cultivated as a vegetable in England, since the time of Queen Elizabeth, is a native of the East Indies. It is the unripe pods that are eaten in England; but in France and Germany, the ripe seeds are preferred, and under the name of haricots blancs, form a part in a great variety of dishes. The Scarlet Runner (Phaseolus multiflorus) is a native of South America, which was introduced in 1633; and it was then so much admired for its flowers as to be generally grown in flower gardens, and always included in the seedsmen's lists of flower seeds. Its unripe pods are by many preferred to those of the common kidney bean; but its ripe seeds are not so good for the kitchen, as they are dark purple, streaked with reddish purple and black, and have a very thick skin.

The Lupine (Lupinus) is a well known garden flower. It is interesting, because when you sow the 
seed, the two cotyledons or seed leaves are so large that you may easily see them open, during the process of vegetation. If you put a lupine seed, or a bean, into a small hyacinth glass, or bottle filled with water, so that the seed may be suspended in the water, you will see the manner in which seeds vegetate in the earth.

First the aril or skin which covers the seed will crack and slip off; next the seed itself will begin to divide into two parts; and then the root will be seen projecting from the little knot that there was on one side of the seed before it was put into the water. The two pieces which the seed split into will now take the appearance of leaves; and, from the upper part of the same knot which sent down the root, will rise, first other leaves, different in shape from the two seed leaves (which are in fact the two halves, or cotyledons as they are called, of the seed), and afterwards a leading shoot, which becomes in time the stem of the plant. The knot from which the root and ascending shoot, or plumule, have sprung, is called the collar, and any injury done to it is sure to destroy the plant. Here is a common bean, which will serve to explain what I have been saying still better than the lupine, because it is larger. See how 
readily it splits into two cotyledons, and how plainly you may see the germ of the future plant in both. Here is another bean, which I contrived to fix in the mouth of a crocus glass, so as to keep the seed in water and allow room for the descending root. See

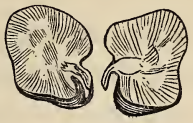
COTYLEDONS OF A BEAN.

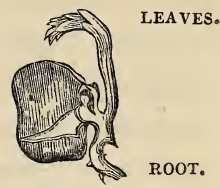

1.

MODE OF GROWTII

OF A BEAN.

here is the plumule ascending, and the root, the point of which I have accidentally broken off; while the skin of the bean is cracking, and will soon fall off, to give the cotyledons room to expand into what are called the seed leaves. There are a great many kinds of lupine; but one of the handsomest is called Lupinus Cruikshankii, its flowers are white, blue, and yellow, and the plant itself frequently grows six feet high.

I am now going to tell you about some of the plants belonging to this genus, which are trees having papilionaceous flowers; that is to say, flowers more or less like those of the bean and pea, and all somewhat resembling the shape of a butterfly. These flowers have their petals in three distinct forms: one petal is larger than the others, and stands up; this 
is called the standard. Two petals in the lower part joined together form the shape of a boat, and are called the keel; and two little petals between the standard and the keel are named the wings. All flowers of this shape are called papilionaceous, and all plants that bear them belong to the order Leguminosæ. There are some plants belonging to this order that have differently shaped flowers; but these I shall tell you about by and by.

There are several trees in English gardens belonging to this order; but they have so many different names, and I have so little to tell you about each, that I am sure you would never remember much about them, unless you were to see the plants. For this reason, I will only tell you a few particulars about the most remarkable of these trees, and you will know the rest by their drooping racemes of flowers.

The Laburnum (Cytisus Laburnum) is one of the most beautiful of these trees. Its golden chains of flowers hang in profusion over the trellis work of my verandah during spring and early summer, when flowers give most pleasure to the eye and heart. Many a cottage garden has been decked with one of these beautiful trees, and many an arbour has been 
shaded by these lovely blossoms. The French call this tree false ebony; because its wood is nearly as black as ebony, and sometimes serves as a substitute for that wood. The wood of the Scotch Laburnum (Cytisus alpinum) is used in Scotland alternately with holly to make the staves of the little wooden vessels called bickers or noggins. The holly wood is smooth, hard, and quite white; and the laburnum wood is smooth, hard, and black; so the two make a pretty mixture, and look very well together. The Scotch laburnum has larger leaves, and larger flowers than the common kind, and some of its flowers are sweet scented. The seed of the laburnum is often sown among valuable foreign trees, to save them from being injured by hares or rabbits, as while there is a bit of laburnum to be had, no hare or rabbit will touch any other tree. There is a kind called the purple laburnum, but the flowers, instead of being purple, are only of a dingy pink, and not at all pretty.

The common Broom (Cytisus scoparius) belongs to the same genus as the laburnum. This is the plant used for making besoms. The long twig-like branches of this tree are cut in the summer, and first spread out to dry, and then tied together with twigs 
of hazel or withy. The Portugal Broom, or Whiteflowered Cytisus (Cytisus albus), and the Spanish Broom (Sparticum junceum), with yellow flowers, are very ornamental plants in shrubberies.

The American Locust (Robinia pseud-acacia) is frequently called the Acacia Tree, but it might more properly be called the White Laburnum, for its blossoms are much more like those of the laburnum than those of the acacia, which I shall tell you about by and by. The flowers come out in long bunches, and smell very sweet; and the leaves of the tree are what are called pinnate, that is, formed of eight or ten pairs of leaflets. These

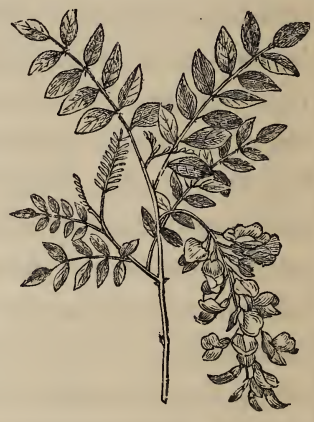

PAISE ACACATA, OR LOCUUST. leaflets close together at night, so that the tree may be said to shut its eyes when it goes to sleep.

This tree grows very fast when it is young, and as its young shoots consist almost entirely of heartwood, they are more durable than young shoots of most other trees. But this premature excellence, like every thing that is premature, does not last long; and when the robinia attains the size of a timber tree, 
its wood is scarcely worth the trouble of cutting down. The branches, too, with their light graceful foliage and beautiful flowers, are so brittle that they break whenever there is much wind, and leave their ragged stumps a sad emblem of the fate of great pretensions unbased on solid worth. The roots, being of what is called the travelling kind, run along just beneath the surface of the ground, throwing up suckers, and impeding the progress of the plough.

There are several kinds of robinia or false acacia. The Pink-flowered Acacia (Robinia viscosa) has the tips of its flowers tinged with pink. The Parasol Acacia (Robinia umbraculifera) is a beautiful tree, spreading its branches, which droop at their extremities just like an umbrella. The Rose Acacia (Robinia hispida) is the last I shall mention. This is a beautiful shrub, with bunches or drooping racemes of large rose-coloured flowers. Unfortunately this elegant shrub, like its tree relations, is liable to be broken by every wind that blows. I had a fine plant, loaded with its deep rose-coloured blossoms, just opposite my window ; but one morning, after a stormy night, when I came into my garden, I found it broken off just above the root, and the whole 
shrub, with all its beautiful leaves and flowers, lying shattered on the ground.

The Gleditschia, or Thorny Acacia, is another tree belonging to this order that I must tell you about, because it is the only tree that I know that has thorns issuing from its trunk. Other trees have thorny branches, but here the very trunk is beset with strong branched thorns.

The beans or seeds of the Kentucky Coffee Tree (Gymnocladus canadensis), which are contained in very large pods, make a very good substitute for coffee. The most curious part of this tree, however, is that in winter it looks as though it were quite dead ; and it does not even show any buds in spring. For this reason the inhabitants of Canada, of which country it is a native, call it Chicot, or the Stump Tree. A short time ago, having the rheumatism in my arms so badly that I could not prune the trees in my garden myself, I hired a man, who said he knew all about gardening in all its branches. As he boasted so much, I thought it very likely he did not know much, so I determined to watch him; but unfortunately, the morning he came, I overslept myself, and when I came into my garden, there was the leading shoot of my poor stump tree lying on the 
ground. "What have you been doing here, my man ?" asked I. "Why, sir," says he, "I do believe the tree is dead altogether, and I might as well have taken it up by the root; but as I thought I would give it a chance, I only cut it down." And so my poor tree was sacrificed, because my gardener did not know its natural habit of growth; and I was punished for indulging in sleep when I ought to have been up and attending to my duty.

Now I have told you so much about the false acacias, I think I should say a few words about the true ones. The true Acacia (Acacia vera) is the tree which yields the gum arabic. It is a native of Africa, and has yellow flowers, not of a pea-flower shape, but in little heads like the flowers of Acacia dealbata that I shall show you by and by. In the country where the gum arabic tree grows, which is principally near Senegal, there are alternate seasons of rain and drought. About the middle of November, when the rainy season has quite closed, a gummy juice exudes from the trunk and branches of the acacia; and in about a fortnight this juice thickens into gum, sometimes hanging from the branches like worms, and at others forming large lumps on the trunk as big as an egg. Towards the middle of De- 
cember, the Moors encamp in the forest to begin their harvest of gathering the gum, which harvest generally lasts about three weeks. The gum, when gathered, is packed in very large sacks of tanned leather, and brought on camels and bullocks to the sea port towns, where it is sold to the English and French merchants who come there to buy it.

There are many other kinds of acacia which are natives of different parts of the world; but the most curious is the Silk Tree (Acacia julibrissin), which is remarkable for its flowers, which look like little tufts of silk about an inch long. The leaves of this plant afford a most convenient natural parasol; when the sun shines bright, they expand and afford a most agreeable shade, but when the weather is cloudy, they close up like those of the sensitive plant and hang down. This tree is a native of Persia, but it grows quite well in the open air in Italy, where I have seen trees of it forty feet high.

The Wattle trees, or Acacias of New Holland are very pretty. There are a great many of them which you may see in the gardens of the horticultural society; but they are all more or less like the acacia dealbata. This tree is called the Black Wattle tree in Australia; but for what reason I am sure I do not 
know, for the stem and branches look as if they were covered with white meal. These trees as you will see have not pea-flowers, but they have pods, or legumes, and that is sufficient to make them belong to the natural order Leguminosæ.

\section{The Sensitive plant (Mi-} mosa pudica) is nearly allied to the acacias. This little

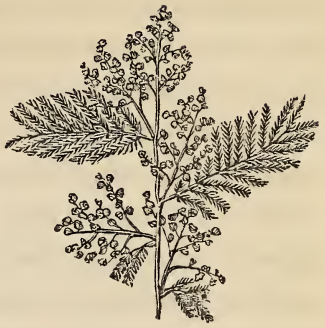
ACACIA DEALBATA, OR BLACK WATTLE TREE.

modest plant shrinks from the slightest touch, closing the leaflets of her leaves, and drooping them as though humbly to beg for mercy from the passer by. This plant is an annual, and is commonly sown in hothouses, where you may have often seen it; but you probably do not know that it has lilac flowers, which are like little balls, and grow five or six together, on one stalk. This plant is a native of Brazil.

- The Carob tree (Ceratonia siliqua) has pea-flowers. This plant is much cultivated in the south of Europe for its pods, the pulp of which is eaten; its vulgar name is St. John's Bread, because some people have fancied that the wild honey which St. John fed on in 
the wilderness was the pulp of its pods; but this is evidently a mistake, as the tree only produces sweet pulp when cultivated in rich soil. The husks which the prodigal son desired to partake of with the swine, are supposed to have been the shells of this plant, after their pulpy matter was stripped off.

The Moreton Bay Chestnut (Castanospermum australe) the only fruit tree that has been discovered in New Holland, is nearly allied to the carob tree. Its legumes contain four large seeds, strongly resembling the common sweet or Spanish Chestnuts, which are very good when roasted.

There are many other trees with butterfly flowers; such as the Siberian Pea tree (Caragana arborescens), and the Salt tree (Halimodendron argenteum), a native of the salt fields of Siberia, which has its leaves covered with a long whitish silky down; the different kinds of Bladder Senna (Colutea), the bladdery capsules of which crack with

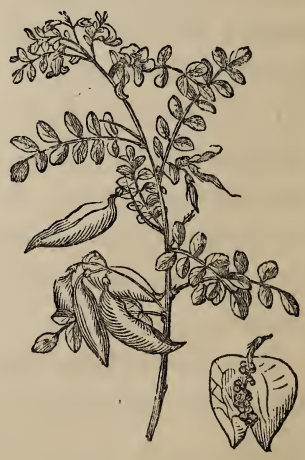

BLADDER SENNA.

a loud noise when clapped between the hands; the 
beautiful plant from New Zealand, with scarlet flowers, called the Parrot's-beak (Clianthus puniceus); the Coral tree (Erythrina crus-galli); that elegant climbing Chinese shrub, with lilac laburnum-like and fragrant blossoms, Wistaria or Glycine sinensis, and the Judas tree (Cercis Siliquastrum). This tree (which was formerly believed to be that on which Judas hanged himself) produces its beautiful pink flowers from the hard bark of its trunk and branches. The flowers are slightly acid, and when fried in butter, make very nice fritters. All these plants are very beautiful, and there are many more; but I fear you will not be able to remember the names even of these.

Common liquorice is made from the root of a plant, belonging to the Leguminosæ, which is a native of the south of Europe, but which is cultivated in different parts of the continent, and even in some places in England. The best liquorice is made in Spain. The liquorice plant (Glycyrrhiza glabra) is propagated by suckers;

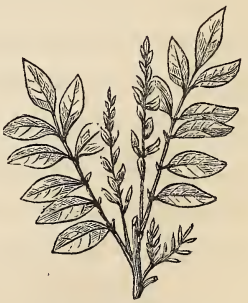

COMMON LIQUORICE. and the plants must be three years old, before the 
roots are ready for taking up. When liquorice is to be made, the roots are boiled, and the glutinous matter which comes from them is strained from the water, and when sufficiently dry it is rolled into long cylindrical cakes, which are called stick liquorice, and are sent to England wrapped up in bay leaves. Little bits of these leaves are often found attached to the pieces of stick liquorice bought in the shops. The refined liquorice is made by dissolving the common kind, and mixing it with gum arabic or common glue, and then rolling the paste formed by the mixture into little narrow cylindrical sticks not thicker than a quill; breaking or cutting them into proper lengths, and lastly polishing them by rubbing them together in a box.

The Tamarind (Tamarindus indica) is the seed pod of a large spreading tree, with very pale green leaves, a native of the East Indies. The flowers are yellow beautifully streaked with red, and with very dark stamens. The wood of the tree is very firm and hard, and it is used for building in the East Indies. The tamarinds we buy,

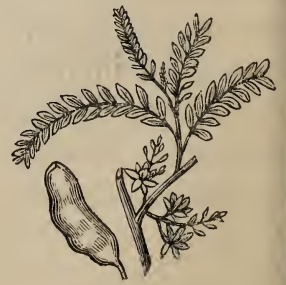

TAMARIND. 
are both from the East and West Indies; those from the East Indies are preserved without sugar, but those from the West Indies are preserved by pouring some of the boiling sugar, when the sugar is making, on the pods; and when there is no raw sugar at hand, by putting alternate layers of fruit and common brown sugar in a jar.

You have no doubt seen necklaces made of red beads each having a black spot at one end. These beads are the seed of a tree called the Red Bead Tree, (Ormosia coccinea) which has large blue flowers; and which is a native of Brazil. The beautiful seeds are enclosed in pods like those of all the other plants belonging to this order; but there is generally only one seed in each pod.

The Wild Liquorice (Abrus precatorius), a native of the East Indies, also produces red seeds, with a black spot on each, that are used as beads, though they are neither so large nor so handsome as the others. This plant is a delicate twining shrub; and as its roots, when boiled, produce a sweet eatable substance, like liquorice, it is called wild liquorice.

The Amorpha fruticosa or false Indigo, is an American tree, the shoots of which are used for making a substitute for indigo. The real indigo is 
however made from a plant called Indigofera tinctoria, a native of India. Indigo is one of the most profitable articles of culture in Hindostan. The indigo is made from the leaves and young shoots; which are ready for gathering about two months from the time of sowing, and which must be gathered in the rainy season, or they will be too hard and dry to yield much indigo. When cut, the leaves and young shoots are steeped in water till all the fleshy matter is separated from the fibrous part; the water is then strained from this substance, which is pressed in cloth bags, and afterwards put into shallow vessels to dry in the sun; when dry it is cut into pieces about an inch square, and packed in casks or sacks for sale. Indigo is also cultivated in the West Indies, and prepared there in the same manner as in Hindostan.

The common Senna (Cassia lanceolata) is a native of Upper Egypt. It is a shrub two or three feet high, with yellow flowers, and pinnate leaves, each consisting of four or five pairs of small yellowishgreen leaflets. These leaflets are the senna. They are stripped off their stalks, and dried in the sun, and little bits of the pods are often found amongst them. The best senna is from Alexandria; but some is also 
grown in the East Indies. There is a kind grown in the south of Europe and the West Indies called Italian Senna (Cassia obovata), but it is not so good as the other kind. The medicine called lenitive electuary is made from the fleshy part of the pods of another plant, called the Purging Cassia or Pudding Pipe tree, (Cassia or Cathartocarpus fistula). It is a native of the East Indies, and the dried pods are brought to England, where the druggists boil them, and use the sediment mixed with the pulp of prunes, and tamarinds, and with liquorice, and senna tea, to make the medicine.

Rice paper is made from a leguminous plant called Eschynomenè aspera. Now what part of the plant do you think is the rice paper? Perhaps you may have thought, like a little girl I am acquainted with, that rice paper was made of rice flour mixed with water, so as to form a paste, and then pressed smooth. It is quite a different thing. The stalks of the plant are full of pith like those of the bulrush, and when the rind has been peeled off, the pith is cut in thin slices round and round. When it is all cut up, the pieces are moistened, and put under a heavy weight to press them smooth; and they are are afterwards blanched to make them of a pure white, or tinted 
with any colour that may be fancied. Rice paper is principally made at Canton in China; but the plant grows wild also in the East Indies, in marshy places and on the borders of lakes. It is used by the Chinese to make artificial flowers.

Before the rice paper was thought so valuable, the Hindoos used to make light hats of it by cementing several pieces together; and fishermen used to tie bundles of its twigs together and use them as a raft, on account of their extraordinary lightness. With this bundle under his arm, and his net on his shoulders, the Hindoo fisherman used to fish the whole day in the deepest and most extensive waters, without a boat.

There are many other curious foreign plants belonging to this division of the Leguminosæ, the most singular of which is the Moving Plant (Desmodium or Hedysarum gyrans). This plant in a hothouse, when in the heat also of the sun, seems to begin to feel itself fidgetty, and it jerks first one leaf and then another, without any one touching it. Then one leaflet will begin to turn and quiver; or perhaps every leaf and leaflet on the whole plant. Sometimes all the leaves will be in a violent state of agitation, shaking in every part; and at other times only one 
or two leaves will move, and those slowly up and down. This very curious plant has violet-coloured flowers of no great beauty, and it is a native of Bengal.

The Chorizema is a little plant which I mention merely for the sake of telling you the origin of its name. It is formed of two Greek words which signify to dance at the sight of water, and the origin of this singular name is as follows. A French botanist named Labillardiere visited the south-west part of New Holland, in search of plants. The country was then only inhabited by the natives, who are savages; and the botanical party were exposed to many difficulties and dangers; and particularly they suffered greatly from the want of fresh water.

After travelling for several days oppressed with heat and fatigue, the small quantity of water which they carried with them became exhausted; and they searched eagerly for a spring. They found one; but, alas! on tasting it, the water was found to be salt, and not fit to drink. They went a little farther and found another; but it also was salt. Wearied with successive disappointments, and just sinking from the combined effects of thirst and fatigue, they at last came to a spring with fresh water, and the 
delight they felt made them almost wild with joy. On the banks of this fresh water they found the pretty little plant in question; and Labillardiere gave it a name which signified to dance with joy at the sight of water, to commemorate what he and his companions had experienced.

I am now going to tell you about a few of the common English plants, belonging to the Leguminosæ, that is, which have butterfly-like flowers, and their seeds in pods. The first of these is the common Furze or Gorse, as it is called in England, or Whin, as it is called in Scotland. The Furze (Ulex Europæus) grows wild on most English and Scotch commons; and its brilliant yellow flowers, which are almost always to be found in the greatest abundance, give a gay and cheerful appearance to many a heath, which, without them, would be but a dull and dreary waste. The furze of England, and of most other parts of Europe, is prickly, and not eatable by cattle till it has been bruised; but in Ireland there is a kind that is perfectly smooth.

The Rest Harrow (Ononis fruticosa) is a little shrubby plant, very common in English fields, which takes its name from its long and spreading roots arresting the progress of the harrow and plough. 
The Kidney Vetch is another British plant of this order. One species (Anthyllus barba Jovis) is called Jupiter's Beard, or the Silver Bush, from the long silky hairs that grow from every part of the plant. This plant has a very pretty effect on rock work.

There are many kinds of forage plants also belonging to this order. The Saintfoin (Onobrychis sativa) is a plant which will grow in the poorest and most rocky soil. It sends its deep roots down through the fissures of the rocks in search of nourishment, and with the little it finds, it contrives to support its large branching and spreading stems. Saintfoin usually lasts eight or ten years, and it is almost invaluable as a food for horses and cows in those rocky districts where no grass will grow.

Lucern (Medicago sativa) is another forage plant that lasts many years. Do you know what a forage plant is? It is a plant that is used as food for horses and cattle, and lucern is a very valuable plant of this kind, not only because it will last many years, but because it will bear cutting four or five times every year. It is reckoned excellent food for cattle, particularly for cows, as it makes them give a great deal of rich milk, which of course produces a great deal of butter. 
In Switzerland there grows a particular kind of clover, with yellow flowers, called Melilot (Melilotus officinalis), the seeds and flowers of which are bruised, and mixed with the curd of the Gruyere cheese to give it its peculiar flavour. If ever you go to Paris, you will most probably taste this cheese, as it is more common there than any other, and if you do, you will perceive what a strong flavour it has.

The common Red Clover (Trifolium pratense) also belongs to this order. Its flowers do not bear much resemblance to those of the pea and bean, but it has the essential character of the order in its podded seeds. Cows are so very fond of clover, that when they are turned into a field of it, they are apt to eat so much as to become what is called blown or hoven. They swell out to a great size, and if not relieved, would soon die. What do you think the relief is? It is to stick a sharp-pointed knife into the body of the animal between the ribs, when the wind comes out, and the creature is instantly relieved.

The Dutch White Clover, or Creeping Trefoil (Trifolium repens), is supposed to be the Irish shamrock, and the plant figured for clubs in a pack of cards.

Now just think over what a number of interesting 
plants I have told you about that belong to the order leguminosæ; that is, that have their seeds in pods like the common bean. This order includes the common bean, the pea, the kidney bean, and the lentil, among the vegetables used at our tables; the lupine, the sweet pea, and the everlasting pea, among our common flowers; the laburnum, the robinia or false acacia, the gleditschia, the acacias of New Holland, the Judas tree, and many others, among the ornamental trees in shrubberies; the tamarind, liquorice, and senna, among the medicines; rice paper, and various other substances, among the curiosities; and vetches, clover, lucern, and saintfoin, among the food for cattle.

\section{QUESTIONS.}

1. What are the distinguishing marks of the Bean and Pea tribe? 2. What is the colour of the wood of the Laburnum? 3. What is peculiar in the Gleditschia or Thorny Acacia? 4. What is the habit of growth of the Stump Tree? 5. What tree produces the gum arabic, and where does it grow? 6. What is the only fruit tree of New Holland? 7. What tree produces flowers from its stem? 8. What part of the liquorice plant is liquorice made from? 


\section{CHAP. XVII.}

THE SAXIFRAGE TRIBE, LONDON PRIDE, AND HYDRANGEA. THE HOUSE LEEK TRIBE. THE TURPENTINE TRIBE. THE NETTLE TRIBE. NETTLES, HEMP, HOPS. TREES BELONGING TO THE NETTLE TRIBE. THE FIG, THE BANYAN TREE, THE UPAS TREE, THE BREAD FRUIT TREE, AND THE COW TREE. THE MULBERRY. MODE OF TREATING SILKWORMS.

\section{THE SAXIFRAGE TRIBE.}

WHo is there among you who has not seen London Pride-the pride of all those little street gardens and beaupots, where nothing else will grow? This plant is a kind of Saxifrage (Saxifraga umbrosa), and there are many other kinds in our gardens; some of them natives of England, like the London pride, and others natives of different countries, some even of China.

The Hydrangea also belongs to the saxifrage tribe, and though it is of a different genus to the London pride, it has somewhat the same kind of flowers, only very much larger. If you were to see the flowers of the London pride through a powerful 
microscope, you would know what I mean. The hydrangeas, however, are all shrubs, and the London pride is an herbaceous plant. The common $\mathrm{Hy}-$ drangea (Hydrangea hortensis) was thus named in compliment to a French lady whose name was Hortense. It is a native of Japan and China, and it is called in the latter country Fundan-kwa. The flower of the hydrangea is first of a greenish white, then it turns pink, and then purplish; but it may be made to turn blue by planting it in peaty soil, or a sandy loam, or by watering it with alum or chalybeate water, or with water in which sheep's dung has been steeped. Hydrangeas are generally kept in greenhouses, but they have been known to grow six feet high in the open air, with branches thirtythree feet round, and to have one thousand heads of flowers on a plant expanded at one time. There are several other kinds of hydrangea, the prettiest of which has leaves like an oak.

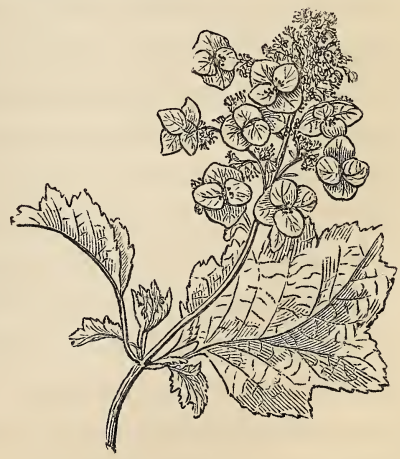

OAK-LEA VED HYDRANGEA. 


\section{THE HOUSELEEK TRIBE.}

There are many curious plants belonging to the natural order Crassulaceæ, the Houseleek tribe, but most of the prettiest will only live in a greenhouse, such as the genus Crassula and others. The common Houseleek (Sempervivum tectorum) is quite hardy, but there are some kinds which are tender; and one, called the Tree Houseleek (Sempervivum arborea), a native of Greece, grows six feet high. All these plants are called sempervivum, because they will live almost for ever, it is so difficult to kill them. I knew a little girl who picked up a bit of the common house leek in the road, that had been trodden on. It looked very miserable and dirty, and most people would have thrown it away; but the little girl was very fond of plants, and she brought it home to her mamma, who put it in a pot with some sand, and by keeping it in a hot dry place, it soon grew to be a nice plant.

The plants belonging to the genus Sedum, or Stonecrop, take their botanical name from their growing on rocks so bare of earth, that there is no apparent nourishment for their roots, so that they look as if they were sitting on the rocks; and 
sedere is Latin for to sit. The name of stonecrop alludes to their growing on stones in the same manner. Bryophyllum calycinum is a very curious plant belonging to this tribe. If a leaf of it be laid on damp earth, a young plant will grow from every notch in the leaf. It is a native of the East Indies, and requires a hothouse in England; and though it is not very beautiful, many persons grow it from curiosity.

All the plants belonging to the houseleek tribe are succulent, and they are all found on rocks, stones, old walls, and in short in any dry and hot situation where not even moss can grow. They require very little soil and very little water, except when they are going to flower, when they should have a great deal. All plants require water when they are going to flower, and if they are kept dry at that season, the flowers will be small and badly coloured.

THE TURPENTINE PLANTS, OR TEREBINTHACER.

Nearly all the plants in this order yield some kind of balsam or turpentine, and nearly all the vegetable varnishes are made from them. Different kinds of balsamodendron yield the balm of Gilead, the balsam 
of Mecca, and the fragrant substance called myrrh, which we read of so often in the Holy Bible. There is a common English weed which is called myrrh, because it is sweet-scented, but the myrrh we read of in HoLY Writ is a kind of gum, which exudes from the bark of a small thorny tree, a native of Arabia, called Balsamodendron Myrrha.

The balsam of Tolu is produced by two trees, natives of Peru (Myrospermum toluiferum and Peruiferum), which grow about forty feet high, and have small yellowish flowers. The balsam is a kind of gum which flows from cuts made in the bark. The Tolu lozenges, which I dare say you have taken when you have had a cough, are made of this balsam mixed with sugar, cream of tartar, and starch.

The pistachia nuts, which, when covered with sugar, are eaten by children and even grown people in France, are the fruit of a tree called Pistacia vera;

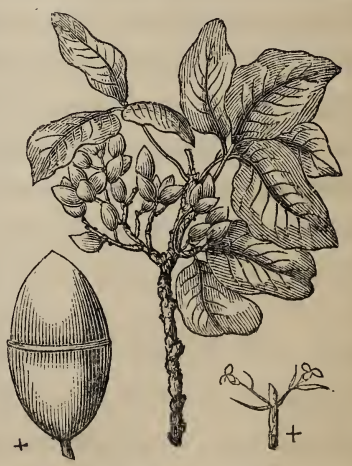

FISTACHIA NUT TREE. and the Scio turpentine (not the common turpentine) 
is the gum or resin of another tree of the same genus, called the Turpentine Tree (Pistacia terebinthus). The Mastick Tree (Pistacia Lentiscus), from which the mastick varnish is made, belongs to the same genus. All these trees are natives of the south of Europe and the north of Africa.

You have no doubt seen some of the Rhus or Sumach Trees, and particularly the Venetian Sumach (Rhus Cotinus), with its roundish leaves and feathery blossoms, which last make the French call it the Periwig Tree (Arbre aux Perruques). The Stag's Horn Sumach (Rhus typhina); the Varnish Sumach (Rhus vernicifera), which yields the gum used in making the fine Japan varnish; and the Gum Copal Tree (Rhus copallina), from which is made the Copal varnish, all belong to the same genus. They are all poisonous ; but there are three other kinds of sumach, which are still more dangerous. These are the Poison Wood (Rhus venenata), the Poison Tree (Rhus toxicodendron, and the Poison Oak (Rhus radicans). This last plant is as common in the woods of America as the ivy is in Europe; and if any one, when cutting wood, chances to wound it, so as to be touched with the sap, or to inhale the smell of the wounded part, it will occasion the whole body to 
swell fearfully, as though the person had been bitten by a viper. A person's hand having been, by way of experiment, completely covered with the sap of this tree, the skin first became as hard as leather, and then peeled off in scales. When the whole body is affected by the odour of any of these plants, a number of pustules, like those of the small pox, appear on the skin, and these are followed by a violent inflammation and fever.

The leaves of the Duvaua (a newly introduced plant, belonging to the same natural order as the Rhus) are so full of a kind of oil or turpentine, that when thrown into water, they start and jump as if they were alive, discharging a jet of oily matter into the water at every start. A handful of leaves thrown into a bason of water will swim on the surface, and seem as if they were dancing. The Cashew Nut Tree (Anacardium occidentale) from Jamaica, and the Mango Tree (Mangifera indica) from the East Indies, also belong to this order, as do many others; many of which are poisonous, and most of which yield some kind of gum suitable for making varnish. The juice of many of the species also serves as a kind of natural marking ink, as any thing written with it on linen turns black, and will not wash out. 


\section{The Netrle Tribe (Urticacea).}

You will perhaps be surprised to find that the Nettle tribe includes the fig tree and the mulberry, with many other plants quite as unlike a nettle as these trees. The reason why botanists have classed these plants together, is that they agree in having their stamens and pistils in different flowers, and in having their leaves covered with rough or stinging hairs, which is the case more or less with all the plants of this order. This order is, however, by some botanists divided into two: the first part comprising the nettle, and all the plants which like it have watery juice, and many of which have their stamen and pistil bearing flowers on different plants; and the second containing the fig, mulberry, bread fruit, cow tree, \&c. which have a milky juice, and generally both kinds of flowers on one plant.

HERBACEOUS PLANTS WITH WATERY JUICE BELONGING TO THE NETTLE TRIBE.

Do you know what I mean when I talk about herbaceous plants? I mean plants the stems of which are not woody. When the stems are woody, the plants are called ligneous. All trees and shrubs 
are ligneous; and all annual and perennial plants are herbaceous.

The nettle is a well-known stinging plant, of which there are several kinds; two of which are common in England: viz. the common Nettle (Urtica dioica), and the Roman Nettle (Urtica pilulifera). Both these plants are furnished with stings which consist of small projecting tubular bristles or prickles, communicating with a bag filled with poisonous juice; they are perforated at the point, and when they are gently pressed vertically, the pressure forces the poison to ascend the tube, and enables the point to lodge it in the skin. Notwithstanding this the tender shoots of the common nettle are used in spring, boiled as a vegetable, or made into a sort of broth, when they are very good. The caterpillars of one of our most beautiful butterflies feed on the nettle; and I have found when I have kept these caterpillars, and wanted to gather nettles for them to eat, that they did not sting me, if I laid hold of them by the collar of the plant, and pulled them up. The stings appear all to point upwards, and when you take hold of their lower part, they do not do any harm.

Bad as the sting of the common nettle is, it is 
nothing to that of some of the Indian species. A sting from the Urtica crenulata has been known to bring on a locked jaw ; and a nettle found in Timor, which is called by the natives Satan's leaf, is said to have occasioned death.

The Hemp (Cannabis sativa) is a very useful plant for cordage. The fibres of the nettle also are so strong that in cases where the plants have grown on rich land, they may be made into ropes and other articles like hemp. The hemp is cultivated in the same manner as the flax, which I have already told you about; and when pulled, it is laid in water to steep like the flax, before the fibres are made into cordage. You have seen a rope walk no doubt, and therefore will know how the fibre when it has been separated and spun is made into rope. Hemp seeds are used for making a coarse kind of oil, and for feeding birds, who are so very fond of this food, that they would eat almost to kill themselves if they were permitted. It is said that feeding a bullfinch entirely on hemp seed, will change its red and yellow feathers to black, but I can hardly think that this can be the case.

The Hop (Humulus Lupulus) is also a very useful plant, though in a very different way from the hemp. 
The ripe capsules of the hop are very bitter, and they are dried and saved, to mix with malt for making beer. The hop is a climbing plant, and in the hop districts, the plants are planted in rows, and twined up poles, like vines. It is a pretty sight to see the hop picking time. The poles are pulled up with the plants covered with their ripe capsules, are laid horizontally on a wooden frame, and the hops pulled off by women and children. They are thrown as they are picked on a hair cloth, and carried on that to the kiln to be dried. The kiln is a large room, the floor of which is full of holes to admit the heat from a stove below. When the hops are sufficiently dry they are carried to another room or granary to cool. When ready to be bagged, that is, packed in sacks for sale, a bag is prepared by fastening its mouth strongly to an iron hoop, and then passing it through a hole or trap door, always left for that purpose in the floor of the drying room. Every thing being ready, a few hops are tied in the lower corners of the bag to serve for handles when it shall be full; the hops are then put in, a few at a time, and the packer gets into the bag, and treads them down as firm and hard as possible. When the bag is quite full, it is drawn up, unloosed from the 
hoop, and the end sewed up, the two upper corners being tied in the same manner as the lower ones for handles.

All these plants have their stamens in one flower and their pistils in another; and these flowers are on different plants. Do you remember what the stamens are? They are generally long slender threads in the centre of the flower, each of which bears a little oblong anther which is covered with a yellow dust, that is called the pollen. The pistil is a little knob in the centre of the flower, which, after the pollen has fallen upon it, swells, and in time becomes the fruit. Now the nettle, the hemp, and the hop, and many other kinds, have some plants that never bear any fruit, that is those which have only stamen-bearing flowers; and others that have only fruit-bearing flowers. This is very curious, and I hope you will remember it.

TREES WITH MILKY JUICE BELONGING TO THE NETTLE TRIBE.

I shall now tell you about the plants which compose the second division of the order Urticaceæ, which are all trees, and all produce a milky juice, that, when dry, partakes more or less of the nature of caoutchouc. 
The common Fig tree is well known for its dried fruit, and if you look at the walls of my cottage you may see the plant in a living state. The leaves of the fig tree are large and somewhat rough, and when broken off the tree, milk issues from the stalk. This milk possesses, in a considerable degree, the properties of caoutchouc, and there is no doubt but that Indian rubber might be made from it, if it were thought desirable, and also for the same reason that silkworms might be fed on the young and tender leaves. I say for the same reason, since it is found, that it is this property in the leaves of the mulberry, that enables the worms fed on them to produce strong silk; and that, if the worms are fed on leaves in which this property does not exist, the silk is not strong enough to be wound off the cones without breaking.

The fruit of the fig tree is very curious. You never see the tree in flower, for the fact is, the flowers are hidden in the fruit. When the fig tree forms its leaf buds early in spring, it forms also little green figs, which are round, and about the size of the end of your little finger. These little knobs are, in fact, the flower buds; and the ripe fruit may be called the seed pod, or rather a capsule containing many seed 
pods. Here, we will gather one of the little green figs from my tree, which grow near the points of the shoots. I will take my penknife and cut it open. See how the milk follows the knife. Now look at the inside. That fringe-like appearance is in fact the flower of the fig; and if you were to examine it with a microscope, you would distinctly see the numerous stamens and pistils of which it is composed. I say the flower, but the fact is that there are many flowers, some consisting only of stamens, and others having each a little calyx, with one pistil in the middle of it. As the fig increases in size, these flowers increase in size also, till at last the pistils change into those little brown grains which you find in such abundance in the centre of dried figs, and each of which contains a seed. Thus you see that what we call the fig is in fact only a fleshy covering, in which the real flowers and fruit are contained.

Ripe figs are thought excellent fruit by some persons, while others do not like them ; but dried figs are general favourites, at least with all the little folks with whom I am acquainted. Perhaps you would like to know how these dried figs are prepared. I will tell you all I know about them. Those sent to the English market are principally ripened in Greece 
and Asia Minor. They are left on the tree till they are fully ripe, which is known by a drop of sweet liquid appearing to hang from the eye. The figs are then gathered and placed on wicker hurdles, in a dry airy shed, and every morning when the dew is off they are exposed to the sun, and remain in the open air during the hottest part of the day. To facilitate the process of drying, the figs are occasionally flattened by the hand; and in moist dull weather, they are placed in rooms warmed by stoves. When thoroughly dried they are packed in rush baskets, or in boxes, in layers, alternately with long straw or bay leaves, and in this state they are sold to the fig merchants. In some parts of the south of France figs are prepared by dipping them into hot lye made from the ashes of branches of the fig tree, before they are dried; the use of the lye being to harden their skins, and thus to make them keep better. It is the white fig only that is dried in the south of France, and this is the kind generally put into the small rush baskets of figs that are sold in Covent Garden market.

The ripe figs sold in England are generally ripened against walls, or in hothouses; but at Tarring, between Brighton and Worthing, there are fig orchards in which the fig trees grow like apple trees, in the 
open air. I have walked in these orchards and seen the ripe figs hang down over my head as if asking to be gathered.

The Banyan tree (Ficus Indica), which is a native of India, is also a kind of fig tree. The fruit it bears are formed in the same manner as the figs of the common tree, but they are red, and about the size of a cherry. The Brahmins use the leaves as plates to eat

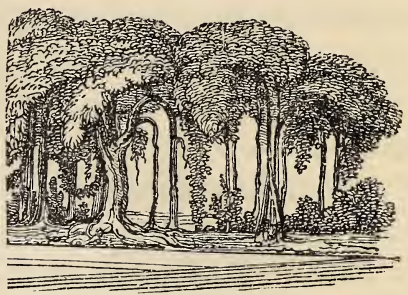

BANYAN TREE. off; and birdlime is manufactured from the tenacious milky juice. The great peculiarity of the banyan tree is, however, its habit of growth. The branches spread to a great extent, drooping at their extremities till they touch the ground, and as soon as they do so, taking root. As soon as this is the case, the stems of what were the branches thicken till they become almost as big as the parent trunk. In this way one tree soon becomes a wood, the trees in which are all joined together by numerous arches, so as to form a kind of verdant cloister. Another singular habit of this tree 
is, that if the seeds are carried by birds, or in any other way chance to drop, into the axils of the leaves of other trees, the young plants produced by these seeds send down roots, which by degrees envelop every part of the other tree except its head. In these cases it is not unusual to see the original tree at the height of seventy feet or eighty feet, peeping through the fig tree, as though wondering how it came there.

The Indian rubber tree (Ficus elastica), from which the caoutchouc first took that name, is also a native of India. Its figs are small, and not eatable, and its leaves are thick and leathery. When wounded, it yields a great quantity of milk ; which, when exposed to the air, separates into a fine elastic substance, which is the Indian rubber, and a kind of whey-like liquid. Fifty ounces of milk yield only about fifteen ounces of caoutchouc, while the Brazilian tree (Siphonia elastica), that I told you about before, yields three or four times as much. For this reason, now that so much Indian rubber is used for waterproof clothes, it is nearly all obtained from Brazil.

The Pippul tree (Ficus religiosa) is held in great respect by the Hindoos, as they believe their God Vishnoo to have been born under its branches. The 
leaves are used in India for feeding silkworms, and are said to produce remarkably strong and wiry silk. On this tree and the Indian rubber tree, the insect is found. which produces the substance called lac, of which sealing wax is made. The insect is of the same genus as the cochineal insect, and is called Coccus ficus. This little insect pierces the branch of the fig tree to deposit its eggs, when a milky juice exudes, which hardens down the twigs, and in this state is called stick lac. When broken off and boiled in water, it is called seed lac; and when melted and formed into thin plates it is called shell lac, and it is in this state that it is used for making the best sealing wax.

The Sycamore fig (Ficus sycomorus) is a native of Egypt, where it is generally planted by the road sides, on account of the refreshing shade afforded by its large leaves, and widely spreading branches. Its figs are small, and very sweet; and, contrary to the usual habit of fig trees, they are not produced on the young branches, but in clusters on the trunk and old wood. The timber of this tree is said by some to be that of which the mummy cases were made. This tree is frequently called the sycamore in the HoLY Bible; and it was on a tree of this species, and not on the 
European sycamore, that Zaccheus mounted to see our Saviour enter Jerusalem. All the fig trees have the same property as the Papaw tree, of rendering meat tender that is hung among their branches. The oldest, and toughest meat, if hung upon a standard fig tree, will become tender in a few hours.

The Bread fruit tree (Artocarpus incisa) is a native of the South Sea Islands, and it requires so hot a climate, that the winters of Bengal are said to be too cold for it. The fruit is as big as a large melon, and contains a kind of pulpy matter, which, when roasted, tastes like crumb of bread. The seeds are also roasted, and taste like chestnuts. The Jack tree (Artocarpus integrifolia) bears an enormous prickly fruit, which often weighs sixty or seventy pounds. Its pulp is yellow, and it is not so good as the bread fruit. It is a native of the East Indian Archipelago. Both these plants are trees from forty feet or fifty feet high, and both exude, when wounded, a quantity of milky juice from which birdlime is made.

The Upas tree of Java (Antiaris toxicaria) has been long celebrated, but so many fictions have been mixed with its history, that its very existence at last came to be doubted. The fabulous story of this tree is as follows: "The poison tree grows in a deep 
valley surrounded by mountains, and its baneful influence is such that no living creature can approach within fourteen or fifteen miles of it without falling a victim to the poison it exhales. The ground is white with the bleached bones of the men and animals that have fallen sacrifices to its venom, and no vegetable can sustain life within the magic circle over which its influence extends. There it stands, the tyrant of the waste, alone in its melancholy grandeur, exhaling its poisonous exhalations, which it is impossible to breathe and live, and which rise like a cloud over the valley, and make the very sky that is above it seem to mourn the horrors it encloses, while the rays of the sun can never penetrate the gloom."

The story continues, that the poison from the tree was that always used by the Emperor of Java, to destroy those persons who had offended him; and for this reason it was necessary to send persons to collect it from the tree, though, as it was a service of great danger, none but criminals condemned to death were employed. "These men," the story adds, "were to be pardoned if they returned in safety. Before they set out on their fatal journey, they visited a Malay priest, who lived fifteen miles from the tree, which was as near as any person could venture to live, and whose 
office it was to prepare the criminals for their task. A priest, who had held this office thirty years, declared that not one in twenty of those who visited the tree returned. All criminals that had been condemned were allowed to choose between instant execution, and the chance of pardon by visiting this tree; but such was the dread inspired by the Upas poison, that comparatively few availed themselves of the offer. The criminals who had chosen this lot then put on their best clothes, and travelled, accompanied by their friends and relatives, to the residence of the priest. There they were each furnished with a pair of leathern gloves, and a long leathern cap, descending as far as the breast, having two eyeholes with glasses, to permit the wearer to see; they were also each furnished with a silver or tortoiseshell box, in which they were to carry the poison. When thus dressed, the criminals took leave of their weeping friends, and following the directions of the priest, ascended a particular mountain, on the other side of which they were to find a running stream, following the course of which was to conduct them to the tree."

Can it be believed that this story, which was published by a Dutch surgeon of the name of Foersch in the year 1783, was entirely a fabrication; at least 
in all the parts relating to the criminals, the danger of approaching the tree, and its solitary situation. The real upas tree always grows in a wood among other trees, and its poison consists in a milky juice which flows abundantly from any incision made in the bark. This milky juice, which is in fact a kind of caoutchouc, which hardens by exposure to the air, is not half so dangerous to the persons who gather it as the gum or resin of some of the kinds of Rhus. If it touches the skin, it occasions a slight eruption, but nothing more. The poison requires to be prepared by mixing it with different herbs, which occasion it to ferment before it produces its full effect. There is a valley in Java like the cratur of a volcano, which is constantly emitting a poisonous gas, like that produced by burning charcoal in a close room; but this gas is not only destructive to animal life, but would kill the upas tree, as well as every other vegetable exposed to it.

The upas tree is often from seventy feet to one hundred feet high, with small flowers and a fruit like a plum. The inner bark contains a fibrous substance which has been converted into ropes.

The Cow tree of South America, or, as it is called by the inhabitants of the Caraccas, Palo de Vacca, 
yields, when wounded, abundance of rich milk similar to that afforded by a cow when she has newly calved. The negroes are very fond of it; and it is said that the Indian women, in those parts of the country where the Europeans have not settled, come every morning to the cow tree with their calabashes to get milk for their families, as the country people in Europe would take a pitcher to the well for water. This milk has been tasted by Europeans and found very good. This is a very remarkable, and almost unique instance, of the milk of one plant belonging to a tribe being wholesome, while that of every other plant belonging to the same tribe is poisonous; but it is the exception, and not the rule.

The Mulberry is the next tree I shall tell you about. The Black Mulberry (Morus nigra) has been called the wisest of all trees; because it is the last to put forth its leaves in spring. When it does begin, however, it loses no time, as its leaves unfold so fast that in hot climates the cracking of the buds as they burst open may be distinctly heard. You have probably heard of Shakespeare's mulberry tree. It was a black mulberry, and it was planted by Shakespeare in the little garden belonging to his house in New 
Place, Stratford upon Avon, in the year 1609-just two hundred and thirty years ago.

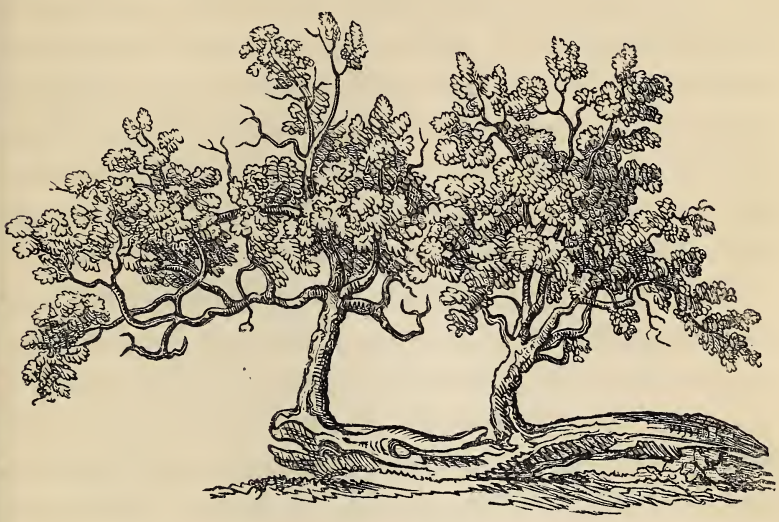

OLD MULBERRY TREE AT CANTERBURY.

The milky juice of the mulberry is not so good as that of the fig for making Indian rubber, but in very hot countries a coarse kind is sometimes made from it. The fruit is like a large blackberry, and you will find a seed in each of the fleshy masses, of which it is composed. The mulberry tree lives to a very great age; that planted by Shakespeare was nearly two hundred years old when it was cut down, and it was then still a thriving tree. When the tree gets old it 
has a way of renewing itself by sending down roots from its branches like the banyan fig tree. If a tree is blown down, the old trunk takes root; and every branch becomes a tree. There is an old tree at Canterbury that this happened to. In the like manner, if a large branch of a mulberry tree be cut off, or blown off by the wind, and merely stuck in the ground, it will grow without any trouble, though it may be as thick as a man's arm.

You have no doubt often heard that silkworms feed on the mulberry, and have probably supposed that it was the same kind of mulberry as that of which you had eaten the fruit. It is, however, quite different; the leaves are much smoother and thinner, and the fruit is white and not eatable. The White Mulberry (Morus alba), and all its numerous varieties, are cultivated for the sake of their leaves all through the south of Europe; and they are now beginning to be very much cultivated also in America. The trees on which the silkworms are fed are generally cut down every year, because the leaves of the young shoots are more tender, and better for the worms, than those which grow on the old branches. Would you like to hear the history of the silkworm? If you would, I will tell you all I know about it. 
The labours of the silkworm are said to have been first noticed by a Chinese Empress 2700 years в. c. This lady having observed the beautiful yellow silky cocoons the worms made, had them gathered and brought to her, and amused herself with trying to unwind the silk. The silk being discovered, the arts of spinning and weaving it soon followed. The Chinese it is said kept the knowledge of this manufacture to themselves for above two thousand years; and though probably there is some mistake in the date of the discovery, it is quite certain that the Chinese knew the means of procuring silk long before the inhabitants of any other country that we know of.

The first silk seen in Europe was brought by the officers of Alexander the Great, on their return from their Persian wars, 350 years B. C., and you may easily imagine how delighted the Grecian ladies were with their new acquisition. The select coteries of Athens could talk of nothing else, and the only wonder was what this splendid new substance could be made of. Some thought it was the bark of a tree, others that it was the fibre of some vegetable like hemp, or that it was a kind of grass growing on the leaves of trees, and some even supposed it to be a mineral, or spun stone like the asbestos: not 
one ever guessed that it was the work of a poor little dirty-looking worm, that they would certainly have crushed beneath their feet if they had seen it lying in their way.

For many years after its introduction, silk sold for its weight in gold; and even in the year 280 A. D. the Roman emperor Aurelian is said to have denied his wife Severa a robe of silk because it was too dear! All this time no one knew what silk was made of. It was first all procured from the Persians, but it was soon discovered that the Persians only bought it of the Chinese; and when the Roman merchants learnt this, and began to deal with the Chinese themselves, they tried every means in their power to discover the secret origin of the silk, but in vain. At length in the reign of Justinian, after the seat of the Roman empire had been transferred to Constantinople, two monks arrived there from China, who disclosed the secret of the silkworms. The emperor on hearing this, was most anxious to procure some of the worms, and though their exportation was forbidden under pain of death, the monks contrived to bring some of the eggs to Europe in the hollow of their pilgrims' staves. They had brought at their first visit seeds of the white mulberry, which 
is a native of China, and had not been before grown in Europe ; and these seeds having been sown, had produced young plants by the time the monks arrived with the eggs of the silkworms. The eggs were hatched in a hotbed, and the young worms being carefully fed with mulberry leaves, and attended to, they succeeded perfectly, and from that time, the silkworm was cultivated in Greece.

Silk was thus introduced into Europe, and the culture of it commenced, in 555, in Greece. It was long confined to that country, till, in 1130, the manufacture was removed to Sicily; and in 1440 silk manufactures were first established in France, from which last country we still get most of the silk used in England. The first silk stockings seen in England were sent as a present to Henry VIII., and they were made of a piece of silk, cut out in the form of the leg, and sewed together behind. The first knit silk stockings were worn by Queen Elizabeth. Since the year 1825 silkworms have been cultivated in America, and the silk made from them is very good. Many attempts have been made to introduce the culture of silk into England, but they have always failed, from the want of heat in the English summers. 
I will now tell you how they manage the mulberry plantations. They cut down the mulberries every year, so that instead of growing like trees, they make only bushes, all of young shoots, like underwood in a forest. The leaves are gathered all at once in the middle of the day, when the sun has dried off the dew. The person employed to gather them strips them off upwards, and deposits them in a bag kept open with a hoop, and provided with a loop and strap to pass over his shoulders. When the leaves are gathered, the trees must be stripped entirely of every leaf; as this is found not to injure the tree half so much, as when only part of the leaves are taken off at a time. The reason of this is, that if all the leaves are taken at once, it produces a sort of artificial winter for the tree; which afterwards forms new buds, and sends forth new leaves just as if a second spring had come. This cannot be the case, if some leaves are left on, for then the tree cannot form new buds where they are; and as the sap must go to every part of the tree at once, if it moves at all, the whole system of its circulation receives a severe shock.

Now would you like to know how to manage the silkworms; or rather, how they are managed by the 
people who have the care of them, when their silk is to be used in manufactures? The eggs, which are of a pale lilac or slate colour, when kept in a cool place will preserve their vitality for several months; that is to say, they have been known to keep good more than a year. When they are to be hatched, they are put into houses built on purpose for keeping the insects in; which have numerous windows for the admission of air, and are furnished with tables and shelves, on which the insects are kept. These shelves and tables have moveable ledges all round them to prevent the insects from falling off. When the mulberry begins to unfold its leaves, it is time to commence the hatching of the eggs. They are then laid on the tables and shelves, and the rooms are heated with stoves, if the natural heat of the climate be not thought sufficient.

When the eggs begin to turn white, they are covered with sheets of writing paper turned down at the edges, and pierced full of holes with a large knitting needle. On the upper side of this paper are laid some young twigs of mulberry, which the insects will smell as soon as they are hatched; and as soon as they are able, will crawl through the holes in the paper, and upon the twig, to try to eat 
the leaves. As fast as the twigs become full of insects they are taken to another shelf, where they are laid on a coarse kind of blotting paper, and some chopped leaves given to the insects, which will soon make them leave the twigs and begin to eat; while the twigs are taken back to the hatching place, for fresh worms to crawl upon. The young worms on the blotting paper are well fed with chopped leaves, and do little else but eat and sleep, till at last they seem very poorly, and after a day or two of illness they begin to change their skin. The silkworm is now in the second stage of its existence, and it is become so strong, that it will eat the young leaves of the mulberry without being cut at all. A great part of this age is also passed in sleep. The third age begins after the insect has changed its skin a second time, and it now becomes lively and vigorous, and will eat even full grown leaves without cutting. After changing its skin a third time, the insect gets into its fourth age, when it changes to a flesh colour, having before been black, and it now eats greedily. Towards the end of this age the insects seem very ill, and at last become torpid, and seem dead; but they are only preparing for the last stage of their existence, and after changing their skins for the last time, they 
enter on their fifth age. They now begin to eat voraciously night and day, and they will eat any thing that is given to them. During the whole period of the life of the caterpillars, the shelves on which they lie will require to be frequently cleaned out; the caterpillars being always attracted to one end of the shelf by fresh leaves, while the other end is being cleaned.

When the caterpillars cease to eat, and run to and fro, frequently looking up, it is an indication that they are preparing to make their cocoons. They have now become transparent, of a clear pearly hue, and the green circles round their bodies will appear like gold. Twigs of oak, tufts of dandelion, rolled up shavings, cornets of paper, and various kinds of sprigs are then placed on the tables and shelves to serve as a support to the insects, and to give them an idea of security. They then immediately begin to make their cocoons by spinning them with threads that are exuded from their mouths. The cocoons are generally finished in from seven to fourteen days. When the insects have done working, the cocoons are taken from the twigs and sorted: those that are double, or in any way imperfect, are thrown aside, a certain number are saved that they may become 
moths and lay eggs, and the rest are set apart for reeling off the silk. The insects in the cocoons are then killed by exposing them to great heat; and the cocoons, having been cleared of the external loose covering which is called flos silk, are thrown by handfuls into vessels of pure soft water, placed over small furnaces of charcoal. When the water is just on the point of boiling, the cocoons are sunk under water with a whisk for two or three minutes to soften the gum, and loosen the silk. The whisk is then moved lightly about till two or three of the ends of the silk threads adhere to it. These are then drawn out, and fixed on the wheel to be wound off; and the silk is reckoned good or bad, in proportion to the length to which the silken threads will bear being wound, before they break.

This is the raw silk, and many, many more hands are required before it can be manufactured into the various articles of clothing made from it. When you put on a silk frock, or even a silk glove, you little think of the labour that has been employed to bring it to the perfection in which you see it.

There is a Tartarian mulberry with deeply cut leaves and red fruit; and an American mulberry called Morus rùbra, or the red mulberry, the fruit of 
which is red instead of black, but it is not of much value, as the fruit is not very good to eat, and the leaves are too rough for the silkworms.

The Paper Mulberry (Broussonetia papyrifera) is a native of Japan, and it is worth telling you about, because what is called India paper is made from the bark. The young shoots of every year are cut in autumn into pieces about a yard long, and boiled till the bark shrinks from the wood, which is then taken out and thrown away, and the bark after being dried, is preserved till wanted. When the paper is to be made, the dried bark is soaked in water, and after having been scraped on both sides, it is boiled in a lye made of ashes till its fibres can be separated by touching them with the finger. The pulp is afterwards shaken about in the water till it looks like tufts of tow. It is then mixed with rice boiled quite soft, and the mass thus formed is afterwards pressed and rolled out in the same manner as is done with paper made in the usual way from the pulp of old rags.

The Osage Orange (Maclura aurantiaca) is another tree, the leaves of which have been used for feeding silkworms. This tree is a native of America, near the Mississippi. Its leaves are smooth and shining, 
and when broken, milk comes from them. The fruit is like a large Seville orange, of a beautiful golden colour, but it is not good to eat. The wood is of a bright yellow, and so fine grained, and elastic, that the Indians use it to make their bows of, and call it Bow-wood. There is another kind of Maclura a native of the West Indies, which is called the fustick tree (Maclura tinctoria), and which is used in that country to make a yellow dye.

\section{QUESTIONS.}

1. What tribe of plants does London pride belong to? 2. What other well known plant belongs to the same tribe? 3. What are the qualities of the different kinds of sumach? 4. What remarkable plants belong to the nettle tribe? 5. What is remarkable about the fig tree? 6. Which kind of mulberry is used for feeding silkworms? 7. What tree is India paper made from?

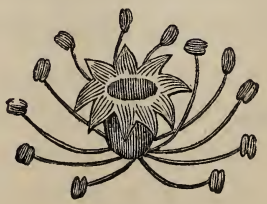




\section{CHAP. XVIII.}

THE ENGLISH OAK. AMERICAN OAKS. OTHER KINDS OF OAK. THE CORK TREE. THE BEECH. THE SWEET CHESTNUT. HORNBEAM. HOP HORNBEAM. HAZEL. CHARACTERISTICS OF THE CUPULIFERE.

\section{The Oak Tribe (Cupuliferc).}

What Englishman is there who has not heard of the British oak? And what American who is not proud of the beautiful oaks of his native land? Old as I am, I remember the rich glow of an American autumn, the first $I$ ever spent in the country. The white oaks, eighty feet or a hundred feet high, with their bright violet-coloured leaves, and shining white barked trunks; the Scarlet Oaks, in all their brilliant variety of hues; the Post Oak, with its strangely formed leaves of blackish green; and the bright yellow of the maples. When I think of these things, I cannot help sighing for those noble trees which once spread over the space now covered with fields and towns. And yet I ought not to regret the progress of civilization. The wild forests only gave 
shelter to wild beasts, and men almost as wild as the creatures they passed their lives in hunting. Arts and manufactures were unknown, and all the nobler faculties of the mind were deadened, because they were uncultivated.

But I forgot it was not of the trees of America that I was about to speak; I must first tell you about one of the chief trees of your native land-the British Oak : that tree of which your ships are built, which form the wooden walls of which England is so justly proud.

The British Oak (Quercus Robur) is a widely branching tree, with large strong arms, and an immensely thick trunk. Its roots spread as widely as its branches, and it looks as if no human force could ever tear it up. Its fruit is the acorn, which is supposed to have been eaten by the ancient Britons, but which has long been only used for feeding pigs. Even in William the Conqueror's time, woods were valued according to the number of swine which it was supposed they could keep. The principal use of the oak timber is for ship building, but when used for other purposes it lasts an amazingly great number of years. There are some doors to an inner chapel in Westminster Abbey, which are said to have 
formed part of the original abbey, which was built in 611 , and which consequently must be now more than one thousand two hundred years old; the wood-work of the shrine of Edward the Confessor, in the same abbey, is eight hundred years old; and there is an oaken chair which is said to have remained in its present situation five hundred and forty years.

The ancient Britons were the first who used the oak for ship-building, the Romans and other ancient nations having made their ships of alder and other light woods. The ships of the ancient Britons were, however, more like what we should now call boats, or rather canoes, if we are to judge of them by the specimens which are occasionally discovered, and one of which is in the court yard of the British Museum. This is a canoe, rudely hollowed out of a single oak tree, and perhaps partly burnt out, for the want of proper tools to work with. There is some difference between these ships and the ships of modern times; one of which, to carry seventy-four guns, requires two thousand trees, each of a hundred years' growth, and which would occupy fifty acres of ground to give them room to grow.

The acorn is the only fruit of the oak, and yet I dare say you have heard of and seen oak apples; 
and last summer you may have seen oak currants, for they were very abundant. The oak apples are the work of a kind of gnat, and if broken open, in their interior will be found a number of cells, each containing a fleshy grub, pupa, or perfect insect, according to the season of the year. The oak currants are formed by another kind of gnat,

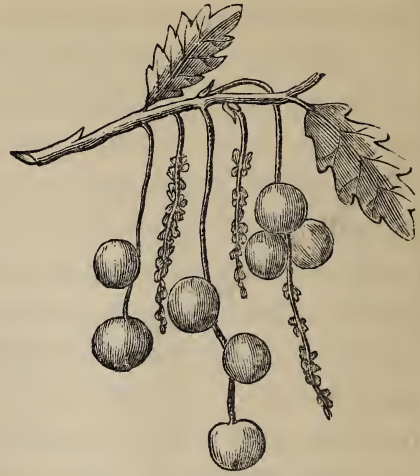

OAK CURRANTS.

which raises the tumour which is to serve as its nest in the flower of the oak. The artichoke gall, also found on the oak, is the work of another kind of gnat. Branches of oak with gall nuts or apples on them are eagerly sought for on the twenty-ninth of May, to carry in procession in honour of King Charles the Second, who escaped, after the battle of Worcester, by hiding himself among the thick branches of an oak tree. This tree has long been dead, for every one who came to see it was so anxious to have a bit of the tree which saved a king, 
that they actually killed the tree by wishing to preserve it.

I shall now tell you about a few of the most remarkable oak trees that I have heard of. The Abbot's Oak, at Woburn Abbey, is interesting, from the abbot of the abbey having been hanged upon it, in 1537, by order of Henry the Eighth. You know, I suppose, that this king, when he abolished monasteries, most cruelly ordered all the abbots and monks to be hanged who would not allow that he was supreme head of the church. This they could not do, unless they had acted against their consciences; for, according to the Roman Catholic religion, to which they belonged, they acknowledged no head of the church but the pope. Many of the abbots, fearing death, and tempted by the offer of a pension, swore whatever the king pleased; but the abbot of Woburn nobly disdained such a compromise, and he was hanged, with the prior of Woburn, the vicar of the next parish, and several of the monks, on this tree, which still stands a monument of the cruelty and injustice which men are led to commit, when they suffer their passions to get the better of their reason. The Raven Oak, in Dorsetshire, was remarkable for a large lump or excrescence which bulged out of 
its trunk at about sixty feet from the ground. The tree was stately and tall, and its smooth trunk was without a single branch till far above the excrescence. On this oak a pair of ravens built their nests every year, for so many years in succession, that at last the tree came to be called the Raven tree. Many were the attempts of the boys in the neighbourhood to get this nest; for though there were many nests on the neighbouring trees, they were so easy to obtain that they were not valued, and it was the difficulty of getting this that made it so charming. Year after year, however, they tried in vain ; the smooth branchless trunk was difficult to climb, and sixty feet was a tremendous height; but even when this height had been attained, there was the large excrescence to be passed, and this proved an insurmountable obstacle. So the ravens built their nests year after year in perfect security, till at last an order was received by the forester to cut the tree down. It was early in spring when this was to be done, and the female raven was sitting on her nest. The forester was very sorry for her, but he was obliged to do his duty, and he hoped that when they began to cut down the tree, the noise and disturbance it would occasion would frighten her away. But he was mistaken. The axe resounded 
through the forest, the saw grated harshly as the woodman passed it to and fro through the butt of the tree, a cord was tied round the trunk, and the tree rocked to and fro, tottering to its fall, yet still the poor raven sate on-she could not leave her young. At last down came the tree with a mighty crash, and the poor raven and her young were all crushed by the fall.

There are or were many other celebrated oaks in England. There was the Fairlop oak, under the shade of the boughs of which a fair was held every year, no booth being suffered to be erected beyond the cover of the boughs of the tree, which extended over a space three hundred feet in circuit. This tree measured forty-eight feet round its trunk, and when it was unfortunately destroyed, by a party, who had been dining under its shade, having accidentally set fire to it, its remains were used to make the pulpit and reading-desk in St. Pancras church, New Road, London. The Yardley oak, which was planted by Judith, niece to William the Conqueror, and which was the subject of Cowper's beautiful lines addressed to an oak tree, stands in Yardly Chase, on the estate of the Marquis of Northampton, who has had an inscription placed upon the tree, begging persons not 
to injure it, by cutting pieces off to take away, but to preserve it in honour of the poet Cowper. The Parliament oak is remarkable for a parliament having been held under its boughs, by Edward I. in 1290 . It stands in Clipstone Park, in Nottinghamshire, which is supposed to be the first park ever enclosed in England. Then there is the Shelton oak, which Owen Glendower mounted to see how the battle went which was fought at Shrewsbury, in 1403, between Henry IV. and Harry Hotspur; and the Cowthorpe oak, in Yorkshire, which is the largest known, as it measures seventy-eight feet round the trunk at the widest part.

In other countries there are also many remarkable oaks. There is the Wallace oak, at Ellerslie, in Scotland, that Wallace concealed himself in; in France, there is the Chapel oak of Allonville, the hollow trunk of which is turned into a chapel; and in Westphalia there is another chapel oak, and one used as a sort of castle, with people living in it.

The American oaks are in general more remarkable for the beauty of their foliage than for the strength of their wood. The White Oak (Quercus alba) produces tolerable timber, and its leaves, as I have already mentioned, change in autumn to a 
bright violet colour. Its acorns are large and very sweet, and on some trees they are of a very deep blue. There are several other kinds with differently shaped leaves and acorns, some of which are almost hidden by their cups, only the point of the acorn peeping out. Here is a sprig of what is called the Mossy-cupped Oak in America, which will show what I mean. You must not confound this, however, with the mossy cupped oak of Europe, for that is the Turkey Oak (Quercus Cerris), and quite different from the American tree. Then there is the Red Oak (Quercus rubra), the leaves of which turn of a deep purplish red in

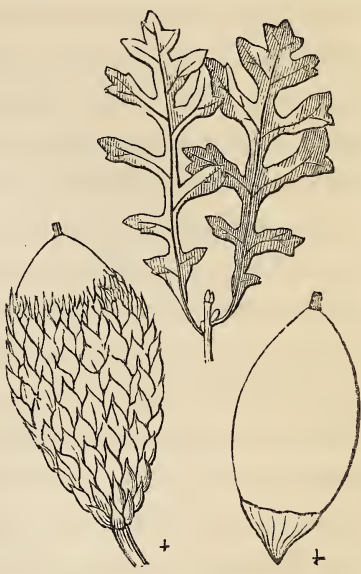

AMERICAN MOSSY-CUP OAK. autumn; and the Scarlet Oak (Quercus coccinea), with leaves turning of a bright scarlet; the Quercicitron (Quercus tinctoria), the bark of which dyes a bright yellow; and the Pin Oak (Quercus palustris), which is a very handsome tree, with very small 
acorns. All these kinds, except the white oak, have timber so coarse grained and so porous, that they will not hold wine or spirits. But the most curious of all the American oaks is the Bear Oak (Quercus ilicifolia), which never grows above three feet or four feet high, though it is a complete tree, and bears abundance of acorns. It is called the bear oak because the bears can eat the acorns, of which they are very fond, as they stand on the ground. The Willow Oak (Quercus Phellos), which has long narrow leaves like a willow, is also a native of America; as is the Live Oak (Quercus virens), which is the principal oak used by the Americans for ship building.

There are several kinds of oak in Europe besides the British oak. One of these is the Turkey or Mossy-cupped Oak (Quercus Cerris), the acorns of which are bitter, and of which species there are a great many very handsome varieties. Then there is the Evergreen Oak (Quercus ilex), which is a native of the south of Europe, particularly of Spain and Italy. This oak will grow close to the sea shore, without being injured by the spray of the sea. The Sweet-acorned Oaks (Quercus Ballota and Quercus gramuntia), the last kind having small prickly leaves, something like those of the holly, and very 
long acorns, almost like the drop of an ear-ring. These are the acorns mentioned in Don Quixote, that Sancho Pançha's wife is said to have sent as a present to the duchess; and they are still constantly eaten by the labourers in Spain.

The Kermes Oak (Quercus coccifera) has been long celebrated for producing the scarlet dye called kermes. The oak itself is rather a shrub than a tree, seldom rising above three feet or four feet high. The kermes has the appearance of a berry or seed; but, like the apple of the common oak, it is the work of an insect, only it is a species of the coccus or scale insect like the cochineal, instead of a gnat. It is hard work gathering the kermes, on account of the prickly leaves of the oak; and the merchants who buy them instantly steep them in vinegar, and afterwards expose them to heat, to kill the insect enclosed. When this is done the kermes are ready for sale; and it is said that the scarlet dyed with them is more permanent than that dyed in any other manner.

You will perhaps be surprised to hear that the cork tree is a kind of oak. It is so, however, and its acorns differ very little in appearance from those of the common oak. It is a native of Spain and the south of France; where it forms an evergreen tree 
from twenty feet to thirty feet high. The cork is the bark, which in old trees becomes enormously thick. The first cutting of bark is taken off when the tree is from fifteen to twenty years old, but this is porous and of little value. Eight or ten years after, a second cutting is taken off, but even this is only sold to fishermen for their nets. The third cutting, eight or ten years afterwards, produces good cork; and from this time, as long as the tree lives, which is generally two or three hundred years, the bark is taken off every ten years without injuring the tree.

In the course of my travels I visited the Cork convent at Cintra. In this convent all the furniture is made of cork. Now, you know cork is very light, so these articles of furniture, which look very heavy and substantial, seem to spring up into your hands when you attempt to lift them. When I was at the Cork convent I laid hold of a very heavy-looking chair, and actually tumbled backwards, when I found it so much lighter than I expected.

Now, would you like to know how they manage to get off the bark of the cork tree. They take a sharp hatchet and make a circular cut all round the trunk of the tree, just under the main branches; and another a little way above the surface of the ground. Then 
they make two or three cuts lengthways, to separate the bark into two or three pieces, according to the size of the tree. When they have done this, they introduce the handle of the hatchet, which is shaped like a wedge, under the bark, and gently loosen it from the tree. The pieces, however, when taken off, are curved, because the tree being round, the bark is naturally in the shape of the tree, and it is wanted to be flat. The pieces of bark are therefore first scraped, to clear them from the rough part of the outer surface, and then held over a blazing fire till they become quite hot and scorched; after which they are laid flat on the ground, and kept in that position for some time with heavy stones. This is the reason why all thelarge pieces of cork, which you see at the corkcutters' shops, look so black on the outside. You may often see cork trees in England; and there is a very large one in the Fulham nursery.

There are a great many other sorts of oaks; some natives of Mexico, and some of Java, and some of India, with very curiously shaped leaves, and acorns; but I shall only tell you of one more, which is a native of Asia. This tree (Quercus infectoria) produces the galls used in making ink. These galls, when full grown, are about the size of a boy's marble, and they 
364

PETER PARLEY'S

are the nest of a kind of gnat, the young of which may often be found in the galls bought in the druggists' shops. Ink is made by steeping them in water, and adding to them sulphate of iron. This, with the addition of gum arabic, makes the common kind of black ink, but there are many other ways of making it. Besides these galls, the Quercus infectoria produces another sort of gall, nearly as large as an egg, but round. These galls have been quite lately discovered to be the far famed apples of the Dead Seafair and smooth to the eye, but crumbling at the touch to dust and bitter ashes.

The common Beech (Fagus sylvestris) is a very handsome tree. Its smooth white bark and majestic habit of growth distinguish it, even in winter, from all other trees; and in summer it is known by thickness and refreshing coolness of its shade. The fruit of the beech is called mast, and it is covered by a husky coat like that of the chestnut, except that it is three cornered. The Purple Beech is a very beautiful tree, and when its rich dark purple leaves glisten in the sun, they have a beautiful effect. There is a very handsome tree of this kind at Enville in Staffordshire, the lower branches of which sweep the ground. There is also a cut-leaved beech, and a tufted beech, 
but they are all varieties of the common species. In America we have two kinds, the white and the red, both somewhat different from the European ones. There is a kind of beech (Fagus Betuloides) which grows in Van Diemen's Land, and was called the myrtle tree by the first settlers, I suppose because it is an evergreen; and which still bears that name in the colony. Some time ago I read in a newspaper, that there were myrtles in Van Diemen's Land seventy feet high, with trunks twenty-one feet round; and I was quite astonished, for I never heard of such myrtles before in my life. In a little time, however, I recollected the odd names the people in Van Diemen's Land and New South Wales give to trees, and on inquiry, I found that their myrtle tree was a beech.

The beech has one peculiarity that I never observed with any other tree, though I am told it has happened with oaks, and various other plants; it is, that where the branches touch each other, they have a tendency to grow together, so as to make curious little arches and holes, in what appears the trunk of the tree. Sometimes two beeches grow together, forming but one head, though they have two roots, and two trunks. In France, the beech 
mast is used for making oil, and the remainder of the mast, after the oil has been extracted, is given to poultry and pigs to fatten them, and to cows to make them produce rich milk. The wood of the beech is very fine grained and hard; and it is used to make wooden bowls, and spoons, and salad forks. In Paris it bears a higher price than any other for fuel; and its branches and spray are distilled for producing pyroligneous acid.

The Sweet Chestnut tree (Castanea vesca) is well known for its nuts, which, as I dare say you know, are excellent when roasted over the fire. If ever you have been in Paris, you must have seen the old women, with their little furnaces at the corners of the streets, roasting the marrons, which are the largest and best kind of chestnuts, and which smell so deliciously, that though I know them to be unwholesome, I never can help stopping to taste one. But chestnuts are principally eaten for food in the south of France and north of Italy. There, when the nuts are ripe, they are knocked off the trees with long poles, and the peasants tread off the husks with their heavy sabots. The chestnuts are then dried on a kiln, and afterwards put loosely in sacks, which have been previously wet, and thrashed, or rubbed 
upon a large table or bench, to get the skins off. They are then ground into flour, which is used as corn flour is in England. The chestnuts sold in England for eating are chiefly imported from Spain, and this is the reason that the sweet chestnut tree is frequently called the Spanish chestnut. It is not a good name, however, for the tree is a native of Asia Minor, and was not introduced into England from Spain, but from Greece, which was the first place it was brought to in Europe.

The wood of the chestnut is good when young, but in old trees it becomes shaky, or what the French call dialled. That is, when it is cut down, it splits into a number of little cracks, all proceeding from the centre, like the rays of a star; and of course is of no use but to burn. Some time ago it was supposed that the wood work of Westminster Hall, and of other old buildings in England and on the Continent, were of chestnut, but it is now discovered that they are of a particular kind of British oak.

I must now tell you about some remarkable chestnut trees. One of the oldest and largest in the world stands on Mount Etna, and is called Castagno di Cento Cavalli, or the Chestnut of the Hundred Horses. This seems rather curious, but I will tell 
you how this tree came to have such a strange name. About the year 1420, Joan II., queen of Naples,

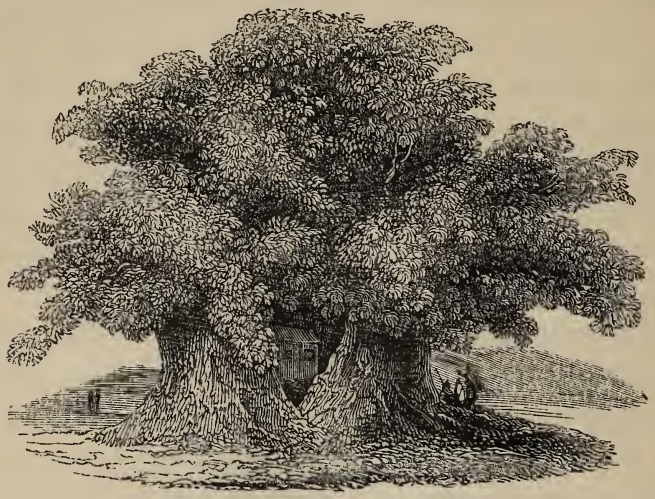

CHESTNUT OF THE HUNDRED HORSES.

being threatened by many enemies, wished to obtain the support of Alfonso of Arragon, who was then king of Sicily. For this purpose the queen (who was a very artful woman) determined to visit the young prince in person; and she accordingly set sail for Sicily, attended by numerous officers of her court. The young king ordered horses to be furnished to her and her suite, and sent officers of his own to meet her, and conduct her to his court. It was on this 
journey that Joan of Naples visited Mount Etna, and that she and her attendants, amounting in all to a hundred persons on horseback, took shelter from a heavy shower under this magnificent tree; the branches of which, the story tells us, were so thick, and spread so widely, that not one of the party felt a single drop of rain.

The glories of the Castagno di Cento Cavalli have long since departed. The trunk has been long quite hollow, and within the last forty or fifty years some country people have turned it into a house, in which they live and have an oven where they dry the chestnuts from the tree for making flour; using its own wood for fuel. With people thus living upon its vitals, the poor chestnut tree of Mount Etna must no doubt soon be no more; yet still the wreck of its mighty trunk measures two hundred and four feet in circumference; and its broken and shattered arms stretch out, as though imploring for mercy and protection.

There are some very old chestnut trees in England, particularly one at Tortworth in Gloucestershire, which is said to have been planted by the Romans, when they were masters of Britain. There are records extant which show that it was an old tree in 
the time of William the Conqueror (1066), and that in the time of Stephen (1135), it was so remarkable for its age and size, that it was used as a land mark ; that is, as a point to measure distances from. It is now a ruin like the Mount Etna chestnut; but as it is taken great care of by Lord Ducie, to whom it belongs, it may yet last a century or two longer. In the park at Cobham in Kent, there is a fine old chestnut called the Four Sisters, and there are many others in different parts of the country. There are also some very old chestnuts in France; particularly the Great Chestnut of Sancerre, which, though known to be more than a thousand years old, appears to be still in a bealthy growing state, and the chestnut of Plessis, which is remarkable for having been used by Louis IX. of France, who was a cruel tyrant, for hanging those persons on, whom he wished to get rid of.

We have a dwarf chestnut in America which we call Chincapin (Castanea pumila). It is a pretty little tree, or rather shrub, seven or eight feet high, and bears abundance of fruit, about the size of hazel nuts, which the children in America eat raw. There are several curious kinds of chestnuts, natives of Java and India, but very little is yet known by botanists about them. 
The Hornbeam (Carpinus Betulus) is chiefly known from having been formerly used in the old style of gardening to make hedges. The hedges of the labyrinths in which the courtiers of Henry VIII. so much delighted, and at troubles occasioned by which, that king himself is said to have laughed so heartily, were all of this tree; as were the star, the goosefoot, and all the other fancies in which gardeners showed their skill in those days, when it was the fashion for gardens to be as unlike nature as possible, and for no tree to be allowed to grow in its natural shape. The hornbeam hedges which were fashionable in England three or four hundred years ago, for making these devices, were ten feet or twelve feet high, trimmed quite smooth, and the top of the hedge sometimes clipped straight, and sometimes cut into half moons. The walks between these hedges were of gravel kept very smooth, or of grass well rolled and closely shaven.

Do you not pity the people who had no other gardens than these? No beautiful flowers, no open lawns, no spreading trees. Every thing was prim and formal, as though the very trees were dressed up in state for company, and every thing like freedom or enjoyment of a garden was forbidden. 
The hornbeam possesses no great beauty either in its flowers or leaves. The flowers form a long loose pendulous catkin, consisting of bracteas, or little thin leaves, rather than flowers. At the bottom of each of these little skin-like bracteas the seed forms, in the shape of a small hard oval nut. There is an American hornbeam, but it differs very little from the European kind; and there are two sorts in Asia which are said to be very handsome.

The Hop Hornbeam (Ostrya vulgaris) takes its name from the curious shape of its catkins of flowers, which look just like hops. Altogether it is a much handsomer tree than the common hornbeam. The Virginian Hop Hornbeam is also rather a handsome tree; and near New York, brooms are made of it by shredding the end of a branch of suitable dimensions. The wood is so hard, that in America the common name of the tree is Ironwood.

What tree do you think I am going to tell you about now? It is one that I think you know very well. At any rate, you know its fruit; and if you have ever lived in the country, you have no doubt helped to gather it. Now, can you guess what it is ? No; then I must tell you a little more. Did you ever taste a hazel nut? Now you know what I mean. 
Yes, it is the tree, or rather shrub, which the common nut grows upon, that I am now going to tell you about.

The common Hazel (Corylus Avellana) is a large shrub, with numerous stems rising from the same root. The leaves are rather rough, and the greenish flowers hang down in long and graceful catkins. These flowers, however, do not produce fruit, for they consist only of stamens; the real fruit-producing flowers are small, and of a bright crimson, looking like little fiery stars. The kernel of the nut is very good to eat, but it is covered with a rough skin, which is very indigestible, and therefore should always be taken off before the nut is eaten.

There are a great many different kinds of hazel nuts, such as the cob nut, the Barcelona nut, and the filbert; but they are all varieties of the common sort. The origin of the name filbert is said to have been full beard, in allusion to the husk, which is longer and more deeply cut in the filbert than in the common nut; but some of the old English poets give it a much more fanciful origin. They tell us that a beautiful nymph, named Phillis, having charmed the fairy king, and made him fall in love with her, so enraged the fairy queen, that in a fit of jealousy she 
made a long beard spring from Phillis's chin. Phillis was so grieved at the loss of her beauty, for, as you may suppose, she did not look very handsome in her long beard, that she pined herself to death; and her fairy lover in pity changed her into a tree, the fruit of which was first called Phillis's beard, a name which, in course of time, became corrupted into filbert.

In ancient times it was believed that certain gifted persons could find out hidden treasures, by holding what was called a divining rod in their hands. This rod was generally a forked twig of hazel, which the diviner held by the two ends, so that the angle of the forked part pointed outwards, and when he drew near the hidden treasure, it suddenly dipped downwards, as much as to say, there it is. You will hardly believe it possible that grown up people could believe in such child's play, but they actually did; and in the remote parts of the country, where education and general knowledge have made but slow progress, divining rods have been used as late as the beginning of the last century.

I shall now tell you a real use that may be made of hazel rods. Hazel rods, cut as nearly as possible of the same size, and varnished, form an admirable material for constructing rustic garden seats and 
flower baskets. An agreeable variety may be produced by using alternately rods that have been peeled, and rods with their bark on, or rods that have been stained with logwood or some other dye, and then arranging them in a pattern. I have seen a complete landscape produced in this manner in the back of an arbour, or garden seat.

There is a very handsome variety of the hazel with purple leaves, and another with cut leaves. There is also the Constantinople Nut (Corylus Colurna), which grows to be a large tree, and the husk of which looks fringed like a tassel; and there are two kinds of American nuts.

Now the oak, and all the trees I have mentioned since, are considered to belong to the natural order Cupulifera, which means literally cup-bearing, because they all have their nuts contained partially or entirely in a kind of cup. You will be able to comprehend this readily in the case of the oak, because the acorn really appears seated in a little cup; but it is not so plain with regard to the other trees. Yet the fact is, the cup of the acorn, the husks of the beech and the chestnut, the little bracteal leaf of the hornbeam, and the husk of the nut, are all of the same nature. They are all different kinds of invo- 
lucres, which first surround the pistil-bearing flower, and afterwards, becoming hardened or elongated, adhere to the ripening fruit. Some botanists call this natural order Corylaceæ, because all the trees in it bear some resemblance to the hazel, the botanic name of which is Corylus.

\section{QUESTIONS.}

1. What tree is principally used in Britain for ship building? 2. How many oaks does it take to make a seventy-four gun man-of-war? 3. What is the Woburn Oak remarkable for? 4. What kind of acorn is still constantly eaten in Spain? 5. What are the oak apples and oak galls? 6. What is the origin of the name of Spanish Chestnuts? 7. Of what country is the sweet Chestnut a native? 8. What were Hornbeams formerly used for? 9. What use is made of hazel rods?

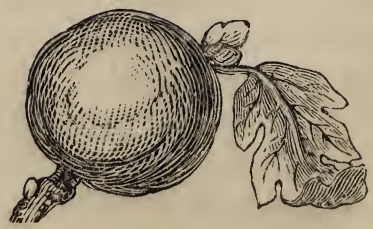




\section{CHAP. XIX.}

THE BIRCH. LINES OF VEGETATION MARKED IN ASCENDING LOFTY MOUNTAINS. BIRCH TENTS AND CANOES. THE ALDER. THE ELM. THE NETTLE TREE. THE WALNUT. THE HICKORY. THE HISTORY OF NAPOLEON'S WILLOW, AND JOHNSON'S WILLOW. THE POPLAR. USES OF TREES BELONGING TO THE WILLOW TRIBE. PLANE TREES. GREAT PLANE TREE OF BUYUKDERE.

\section{The Birch Tribe (Betulacece).}

WHEN I was telling you the distinguishing marks of the oak tribe, or Cupuliferæ, I did not mention among them, the fact, that plants of that tribe have their stamens and pistils in separate flowers; and also, that their stamen-bearing flowers, are disposed in catkins, which are so called, because they hang down like cats' tails. I did not tell you this, because these characteristics are not confined to the oak tribe. Birch trees and alders agree with the oaks exactly in these particulars, but they differ in not having any involucre or cup round their fruit.

There are many interesting things to be said about 
the birch. These trees are the last that are found on lofty mountains before the traveller arrives at the dreary region of perpetual snow. As the traveller ascends, by degrees the trees get smaller and smaller. First the fruit trees disappear altogether; then the maples, limes, and beeches; higher up the oaks vanish, and the forests look black with immense masses of pines and firs. Above, a few little willows appear shrunk down to paltry shrubs, and dwarf rhododendrons and heaths nearly cover the ground, with here and there an alder, and abundance of birches. Higher still, all the rest disappear, and the birch alone remains; shrunk down indeed to the size of a shrub, but still growing vigorously, till at last it touches the very margin of the snow.

The common Birch (Betula alba) is the most graceful of all trees. Its silvery bark, and elegantly drooping branches justly entitle it to the name it has acquired of the Lady of the Woods. Even when the leaves have fallen, its long catkins, have a singular and beautiful appearance. It is also a very useful tree. Its bark scarcely ever decays, and it is used by the Laplanders for covering their huts. A kind of wine is made of the sap which exudes when a hole is bored in the trunk. Oil is also made from 
the bark, and pyroligneous acid is distilled from the branches. The spray is burnt for smoking dried fish, mutton, hams, and beef, and also for distilling whiskey. In short, I cannot tell you one half of the uses to which it is applied; and the poor people who have no other tree, find in it, a substitute for all those of which nature has deprived them. With the birch for their timber tree, and the rein-deer as a substitute for horses and cattle, these poor people

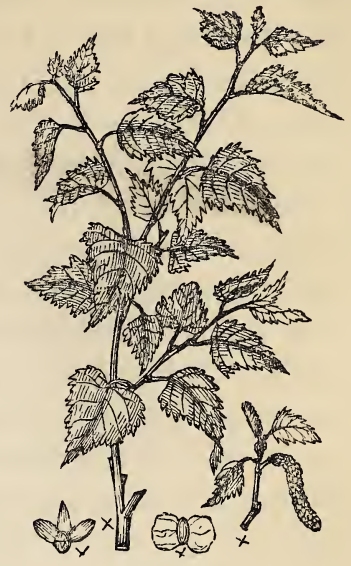

BIRCH TREE. manage to live, and even to enjoy all the luxuries of which their habits are susceptible. So merciful has the Almighty Creator been even to these poor Laplanders, who seem to dwell on the extreme verge of civilization.

There is one use yet of the birch which I have not mentioned-birch rods are made of it-but I dare say these are things with which you have not the least desire to become better acquainted. 
There are a great many different sorts of birches. One with drooping boughs, sweeping the ground, and "arching like a fountain's shower ;" and several American kinds, some distinguished by their upright catkins, and somewhat stiff habit of growth; and others as graceful and beautiful as the European lady of the woods. One of the last (Betula papyracea) the Canoe or Paper Birch, has a bark which forms a very good substitute for paper, when divided into thin laminæ; and which, when entire, is made into canoes. To procure proper pieces for this purpose, the largest and smoothest trunks are selected. In the spring, two circular incisions are made several feet apart, and two longitudinal ones on the opposite sides of the tree; after which by introducing a wooden wedge, the bark is easily detached. The plates are usually ten or twelve feet long, and two feet nine inches broad. To form the canoe, they are stitched together with the fibrous roots of the white spruce, about the size of a quill, which are deprived of their bark, split, and rendered supple by steeping them in water. The seams are then coated over with the resin of the Balm of Gilead fir. Great use is made of these canoes by the American Indians, and by the French Canadians in their long journeys 
into the interior of the country; for as the canoes are very light, they are easily carried on the shoulders from one lake to another. A canoe calculated to contain four persons with their baggage, weighs only from forty to fifty pounds, and some of them are made to carry fifteen persons. In the settlements of the Hudson's Bay Company, tents are also made of this bark, and they are not only easily carried, but so rapidly put up, that a circular tent twenty feet in diameter and ten feet high, does not require more than half an hour to pitch it. When I was among the Indians I have often seen these rind tents, and floated down the streams in birch canoes.

The Alder (Alnus glutinosa) differs from the birch, principally in having its catkins of pistil-bearing flowers in bunches of four or five together, whereas those of the birch are always solitary. The seeds also of the birch have a membrane on each side which those of the alder have not. The alder may be almost called an aquatic tree, since it is never found of a large size, but in wet swampy ground, where scarcely any other tree will grow. In dry situations, it becomes poor and stunted; and on mountains dwindles down to a shrub. It thrives best by the side of a dull sullen looking pond, where 
its stiff form when reflected in the still water, seems in perfect harmony with the scene. There are several kinds of alders, but most of them are shrubs; and only two of them can be called ornamental. One of these, Alnus cordifolia, is a large handsome tree, with broad, deep green, shining, heart-shaped leaves; and the other, Alnus viridis, is a shrub, profusely covered with its long gracefully drooping

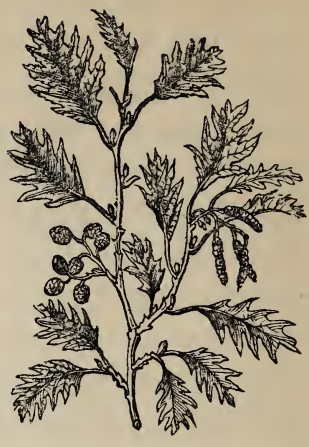

ALDER TREE. catkins.

\section{The Elm Tribe (Ulmacea).}

The English Elm (Ulmus campestris) is a tall upright growing tree with few branches, and those very small in proportion to the height and thickness of its trunk. In this respect it affords a striking contrast of the oak, the branches of which are very thick and spreading. It is on account of its upright and compact habit of growth, that it is a favourite tree for hedgerows. In Italy, elms are generally planted in rows, with the branches kept short like 
the steps of a ladder, to serve as props to the vines, which are planted at their feet. This practice is frequently alluded to by the ancient Roman authors, and particularly by Virgil in his Georgics; and it is curious to find the Italian peasants training their vines in the same manner, and on the same ground, as their Roman forefathers did so many ages before them. Elms are subject to many diseases, and to the attacks of numerous insects, particularly to those of a little creature not so big as a small fly, which eats its way into the timber, and in a short time destroys the tree.

There have been several remarkable elm trees. One at Crawley on the road from London to Brighton has its hollow trunk paved with bricks, and made into a kind of room, which is about twelve feet wide. This room has a door which is generally kept locked, but on particular occasions certain persons belonging to the parish dine in it. A large elm formerly stood at Hampstead, in which there was a staircase leading to a turret at the top, in which people used to sit and enjoy the prospect. This tree was blown down about a hundred years ago. And lastly, in Kent, there is the lifeless trunk yet standing of the Chipstead elm, which died in 1836. The owner of this 
celebrated tree has placed a fence round the mound on which it stands, and a seat close to the tree, the trunk of which is still of enormous bulk.

The Scotch or Wych Elm (Ulmus montana) has not so upright a trunk as the English elm, and it soon divides into long, widely spreading, somewhat drooping branches, forming a widely spreading tree. The wych elm is a native of Scotland, and you will perhaps be anxious to know what it has to do with witches, as appears implied by the sound of its name. The fact is that the name is wych, not witch, and wych in Saxon signifies a salt spring, as Nantwich, Droitwich, \&c. But what has this to do with the elm? you will ask. Have a little patience and I will tell you. There is no wood in England that will bear the corrosion of salt so well as the elm; and all the troughs which convey the salt water from the salt springs to the vats for boiling and evaporating the water are made of elm. You will now see why the tree is called wych elm. The most remarkable wych elm in England is at Tutbury in Gloucestershire, it is above sixty feet high, and has branches which extend above sixty feet from the trunk on each side, but there are some much larger in Scotland, for there is one at Pollock above ninety feet high. 
The Dutch Elm (Ulmus suberosa) has thick corky bark, almost like that of the cork tree. The Chinese Elm (Ulmus chinensis) is a very curious little plant, which the French call the Tea of the Abbé Gaulois. This last name arises from the Abbé Gaulois, who lived in the reign of Louis XV., having sent to China for a specimen of the tea plant, and the person whom he employed, having brought him this plant instead. The Chinese elm is naturally a dwarf, but the Chinese contrive to make it look still smaller than it really is, by planting it in a China vase, and giving it but little nourishment. I have seen some of these trees, looking as if you saw a real old elm through the diminishing end of a telescope. The Chinese contrive to distort the trunk, and give it an appearance of old age, by tying wires round it, and fastening them to stakes so as to make the stem crooked. They then wound the bark to produce protuberances, and mutilate some of the branches to give them the appearance of the withered stumps of a tree in extreme old age. And thus an elm tree is produced not above one or two feet high, which has a writhed and knotty trunk, rough and weather-stained bark, and partly dead branches; possessing in short all the appearance of a forest tree in the last stage of decay. 
There are a great many other kinds of elm, some natives of America, and some of England, but the handsomest is the Weeping Elm (Ulmus rubra).

The Nettle tree (Celtis Australis) is remarkable for its fruit, which resembles a small cherry, and is supposed to have been the Lotus of the ancients, the food of the Lotophagi, which Homer says was so delicious as to make those who ate it forget their country. I do not know how this may be, but I only know that if the fruit was not very much better in Homer's days than it is now, the Greeks must have had a curious taste in fruit. The wood of the nettle tree is very smooth and fine grained, and it is used in France for carving the figures of saints for the Roman Catholic churches. It is also used for making tubs and cisterns, and for hay forks. Of the latter, so many are made of it, that there is one plantation in France, from which above five thousand dozens of hay forks are made every year! Besides this, when the tree is cut down, it sends up a number of strong and vigorous shoots, which are used for whips, ramrods, and walking sticks.

There are several other kinds of nettle tree; some natives of Europe, and some of America, but the most remarkable is that called the Hockberry or Hoop Ash 
(Celtis crassifolia), which has large thick leaves and black fruit.

\section{The Walnut Tribe (Juglandacea).}

The common Walnut (Juglans regia) is a noble tree, with widely spreading branches, and large leaves. It is a native of Persia, but it has been cultivated in Europe for many ages. The ancient Greeks called it the Royal Nut, and dedicated it to Diana; but the Romans called it Juglans, or the nut of Jove. In modern times, it is cultivated not only for its fruit, but for its wood, which is reckoned better than any other for making muskets of. There are many different kinds of the common walnut distinguished by their fruit; the most curious of which is called the Titmouse Walnut; because its shell is so tender that these birds can pierce it with their bills, to obtain the kernel, which they will pick out, and leave the rest of the shell and husk remaining on the tree.

I have already told you that the walnut is a noble tree, but I must now say a few words on its botanical character. Its leaves are what is called pinnate; that is, they consist of several pairs of leaflets, and a solitary one at the extremity. The flowers are in 
catkins, something like those of the oak, and the hazel, but longer, and fuller; and, as is the case with those trees, the stamens and pistils of the walnut are in different flowers. What we call the walnut is in fact the stone of the hard, but fleshy husk in which it is enclosed; and the part that we eat is the kernel, which, like the kernel of the hazel nut, and that of the almond, is covered with a thick skin unwholesome to eat. This kernel, when the skin is taken off, will be found to separate readily down the middle into two cotyledons, like the seed of the lupine; and the germ of the young plant may be easily discerned at the point at the extremity of the kernel, with the part which is to form the root pointing outwards. This is commonly called the heart of the walnut.

Walnuts are not only used for eating, but for making oil, particularly in Switzerland; and many a happy hour I have passed in that country in the walnut harvest. The nuts are knocked off the tree in September, but it is in November that what I call the harvest commences. Then the young men and maidens assemble in the farm houses, to crack the walnuts, and take them out of their shells. The walnuts should be used as soon as possible after they are 
taken out of their shells, and these good peasants help one another, so that all the walnuts belonging to each person may be taken out at once.

I was at one of these parties, where thirty persons sat round a long table. A man at each end cracked the walnuts by hitting them on the point with a wooden hammer, and as soon as this was done, he tossed them down the table. Then there was laughing and joking as the young men and maids caught the rolling walnuts. Then the song and the merry tale went round, and when the kernels were all picked out of their shells, there was a shout of joy; they all rose, the table was put away, and they continued dancing all the remainder of the evening.

The kernels of the walnuts are afterwards crushed and pressed, and the mast or paste, left after all the oil has been pressed out, is made into little cakes, and sold to the children of poor people under the name of pain amer, or bitter bread. The husks of the walnuts are burned, and their ashes are mixed with water, to make what is called a lye for washing linen. A dark brown dye is also prepared from walnuts, which is used by persons who pretend to be gipsies, to dye their face and hands of the same colour as those of the real gipsies; and this dye is made from the juice 
of the husks, or unripe fruit. If you were to help the cook when she is pricking walnuts before pickling them, you would soon see what a colour walnut juice can dye, by your own hands.

In America we call our walnut trees Hickories. There is one kind, the Black Hickory (Juglans nigra), which makes a very lofty tree. The leaves have six or eight pairs of leaflets, while the common walnut has but three, and the fruit is round, instead of oblong. The husk is very thick, and the nut is as hard as a stone. When cracked, which is not a very easy task, it will be found half full of hard ligneous partitions, and the kernel very small, and not worth eating. The wood is very hard and very durable; so much so that we have a proverb which says, "as tough as hickory." When put into the ground this wood lasts longer than any other, and for this reason coffins are made of it. We also make shingles of it. Perhaps you do not know what these are. They are thin pieces of wood about eighteen inches long, and six inches broad, which we use instead of tiles to cover houses with.

The Butter Nut (Juglans cinerea), the Bitter Nut (Carya amara), the Water Hickory (Carya acquatica), and the Pig Nut (Carya porcina), are all dif- 
ferent kinds of hickory, of not much value for their fruit. The Pecan Nut (Carya olivæformis) is, on the contrary, very good. This nut was a great favourite with General Washington; and it is said by a French gentleman, who served in his army in 1782, during the American war, that during the whole campaign, he had his pockets always full of these nuts, and was continually eating them!

The Shell Bark Hickories (Carya alba, and sulcata) have nuts enveloped in a very thick husk, which opens into four parts when it is ripe, and lets the nut drop out. The nut has a very thin shell, but it is so hard that it is as difficult to break as some of the thick ones. The kernel, however, is worth taking some trouble for, as it is large, and very sweet and good.

I have only one more species to tell you about, and this is called the Mocker-nut Hickory (Carya tomentosa). The nut is very large, and looks tempting, but the shell is very thick and extremely hard; and even when it is broken, there are such strong partitions in the inside, that only a very little bit of the kernel can be picked out, before there is another shell (as each partition may be called from its hardness) to be broken, and then another, and so on. For this 
reason it is called the mocker nut, as it seems to be mocking you as you go on.

There is very little difference between the hickory and the walnut; in a botanical point of view, the flowers are not exactly the same, and the husk of the walnut when ripe bursts irregularly, when it does open, and drops with the fruit enclosed; while the husk of the hickory nut opens, while on the tree, into four smooth divisions, and lets the fruit drop out. The nut of the hickory is also smooth, while that of the walnut is rough; and the tree of the former is not so robust as that of the latter.

\section{The Willow Tribe (Salicacece).}

There are two distinct kinds of Willow, those with narrow leaves, which are the true willows, and those with round leaves, which are the sallows. The willows are also again divided into the shrubby kinds or osiers, which are cut down every year, and the shoots sent up by which are used in making baskets and hoops; and the tree willows, which grow sixty feet or seventy feet high. Besides these great divisions, they are subdivided into above two hundred different species.

The Weeping Willow (Salix Babylonica) is one of 
the tree kind. It is a native of the banks of the river Euphrates near Babylon, and it is mentioned in the Holy Bible. It is said to have been first planted in England by Pope, the celebrated poet, who chanced to be with Lady Suffolk when that lady received a parcel from Turkey. This parcel was bound round with withy, and Pope taking up one of the pieces, found it so green that he thought it would grow, and he observed that perhaps it might produce something not already in England. The story goes on to say that he planted the piece of withy in his garden, where it grew to be the tree afterwards so celebrated under the name of Pope's Weeping Willow. This tree was cut down in 1801 by the person who then possessed the willow, because he was annoyed at so many persons coming to ask to look at it.

The weeping willow is generally planted near water, where it has a very pretty effect; but it is also planted in churchyards, and over monumental urns in pleasure grounds, because, as a French writer observes, "its sweeping branches, and long leaves give the idea of the dishevelled hair, and neglected drapery of a mourner." The tree called Napoleon's Willow grew at St. Helena, and Bona- 
parte, when he first went there, used to enjoy sitting under its shade. The night that he died, a violent storm shattered the willow to pieces; and when he was buried, Madame Bertrand, knowing how fond he had been of this tree, had several cuttings of it planted round his grave; and from these all the trees brought to England as Napoleon's willow have been raised.

Johnson's Willow was one of the kind called by botanists Salix Russelliana. This tree stood near the public footpath in the fields between the city of Lichfield and Stow Hill, the residence of the lady whom Dr. Johnson used to call Molly Ashton. The doctor was very stout, and as he was not the best of walkers, he was very glad to sit down under this tree, to rest before he climbed the hill. Hence it was called his tree. In 1781, it was measured by the doctor's desire, and it was found to be about fifty feet high, and that the circumference of its branches was two hundred feet, it being then apparently about one hundred years old. A few years after, the doctor died, and the tree gradually fell to decay, till in 1810 a violent storm carried away half its boughs; a few years afterwards part of the trunk fell, and left a hollow gap, in which some silly boys 
made a fire. The poor tree of course took fire, but it was saved from destruction by a gentleman, who saw it, sending for the parish engine; though it was very much weakened by the accident, and a few years afterwards it was blown down.

The Black Sallow (Salix capræa) is well known for its large and handsome catkins of yellow flowers. The flowering branches of this species are called palms by the country people, and are gathered on Easter Sunday by the children and young people in commemoration of the entry of our Saviour into Jerusalem. I do not know why this shrub was fixed upon as a substitute for the real palm tree, which only grows in hot countries, for it is as unlike as possible.

The poplars are nearly all of them well known trees. The White Poplar or Abele Tree (Populus alba), has a very curious effect when it is seen at a little distance. The underside of the leaves of this tree is quite white, and the upper side very dark green, so that when the wind blows, the leaves seem of two different kinds, or rather, the white side looks like flowers.

The Aspen (Populus tremula) is remarkable for the constant trembling of its leaves. The Black 
Poplar (Populus nigra) has its catkins rather short, and those of the stamen-bearing flowers are of a dark red. These catkins have a very curious effect on the tree, but still more so when they fall off, as they look exactly like great red caterpillars. The capsules of the seeds are enveloped in a kind of cotton, on which account, in Suffolk, the tree is called Cottonwood.

The black Italian Poplar (Populus monilifera) produces still more cotton on its seeds than the common black poplar. The ground under the seedbearing trees is often indeed quite white, as though covered with down, at the season when the seeds are ripe. The botanical name of this species signifies the necklace-bearing poplar, in allusion to the appearance of its seed-pods, which look like the beads of a necklace, strung at regular distances from each other.

The Lombardy Poplar (Populus fastigiata) is remarkable for its stiff upright habit of growth, its shape being nearly that of the flame of a candle. The catkins are very much like those of the black Italian poplar, and its seeds have very nearly as much cotton.

All the poplars and willows have their stamen- 
bearing or male flowers on one tree, and their fruitbearing or female flowers on another. This is one great point of difference between them and the birch tribe, in which both kinds of flowers are on the same tree. Another point is that the seeds of plants of the willow tribe are hairy or woolly, which those of the birch tribe are not. The willows and poplars are so little alike in general appearance, that I think no one, who was at all acquainted with trees, could mistake one for the other; and yet their botanical distinctions are very slight. The willow has nothing like a calyx to its flowers, while the poplar has a little membrane, which may be considered as the rudiment of one; and the poplar has never less than eight stamens in each male flower, while the willow has scarcely ever more than five. This is nearly all the difference that botanists can discover between them. The bark of all the trees belonging to the willow tribe is good to take in cases of fever; and it is a remarkable provision of Almighty Wisdom, that these plants, particularly the willow, grow in swampy situations, where fevers are most abundant; so that the same soil that produces the disease, produces also the remedy. The wood of both the poplars and the willows is very white, soft, and elastic, and it is 
used for making bats to play at cricket with, and for lining carts and wheelbarrows for carrying stones, as from its elasticity it does not receive any injury from a blow. When the large White Willow (Salix alba), that stood on the common at Turnham Green, was blown down in the dreadful storm of November, 1836, the wood of the whole tree was instantly bought up by the cricket-bat makers.

The Plane Trees (Platanus orientalis and occidentalis) are nearly allied to the willow tribe, but are distinguished by their round heads of flowers. They are both noble trees, particularly the oriental plane tree. This is a favourite tree in Persia, where it is called Chinar; and there are few cottages in that country without a plane tree, for the inhabitants to sit under its shade. There is a plane tree at Buyukdere, in Turkey, which is supposed to be one of the largest trees in the world. The trunk of this tree, which is hollow, is one hundred and forty-one feet in circumference, and when the Turks encamp in the valley in which it stands, it affords a magnificent tent to the seraskier who commands them, and all his officers. This enormous tree cannot be less than two thousand years old.

The American Plane Tree is called with us Button- 
wood, Sycamore, and Cotton Tree. It is remarkable for the great quantity of down which covers the under surface of its leaves when they first expand, and which becomes gradually detached from them in the course of the summer. In some parts of the United States, where the tree is very abundant, the inhabitants regard it with dread, as they think that this down, detached and floating in the air, produces irritation of the lungs, and finally consumption. The occidental plane was one of the first American trees introduced into England.

\section{QUESTIONS.}

1. What is the last tree found npon lofty mountains? 2. What is the hotanical difference between the Alder and the Birch? 3. Why is the Elm preferred to the Oak for hedge rows? 4. What is supposed to be the origin of the name of the Wych Elm? 5. What was the Nettle Tree called by the ancients? and what does Homer say of its fruit? 6. Of what country is the common Walnut a native? 7. What is the timber of the Walnut used to make? 8. What kind of leaves has the Walnut? 9. What are Walnuts used for besides eating? 10. What are the American Walnuts called? 11. What is the principal quality of the Hickory wood? 12. What is the difference between Willows and Sallows? 13. What are osiers? 14. What is remarkable about the leaves of the American Plane Tree? 


\section{CHAP. XX.}

THE MEZEREON. THE SPURGE LAUREL. THE SWEET BAY. THE CAMPHOR TREE. THE CINNAMON. PEPPER. BEET AND MANGOLD WURTZEL. RHUBARB. HEATHS. ARBUTUS TREE. BILBERRIES AND CRANBERRIES. RHODODENDRONS, AZALEAS, AND KALMIAS. THE PRIMROSE TRIBE. CONVOLVUluS. PHLOXES. LOBELIAS. CAMPANULAS OR BLUE BELLS.

\section{The Mezereon Tribe (Thymelacea).}

IT is a remarkable fact in the history of plants, that some of the prettiest and simplest looking are the most poisonous. Who, for example, looking at the pretty flowers and bright red or yellow berries of the common Mezereon (Daphne Mezereum), would suppose that it was poisonous? Yet so it is; these berries are a deadly poison to mankind, though birds eat them uninjured. The bark, too, of all the plants belonging to this order is so acrid, that if moistened and bound on the skin, it produces blisters, in the same way as the bark of the clematis, which I told you about before.

If you gather one of the flowers of the common mezereon, and open it, you will see that the stamens 
are not placed as we have been used to see them, but fixed to the inside of the tube of the flower. You will see, too, that there is no calyx, or rather, as a botanist would describe it, there is no corolla; for that pretty lilac part, which we call the flower, they call a coloured calyx. If we examine it still more closely, we shall find that the coloured skin will peel off, and leave another coloured skin behind, so that the flower is double, or, as the French botanists describe it, lined. The fruit of the mezereon is a little plum rather than a berry, as it encloses only one seed or stone.

There are many kinds of daphne with lilac flowers, resembling those of the common mezereon; and there are some with greenish flowers, such as the common Spurge Laurel (Daphne Laureola); but they all agree in the formation of their flowers,

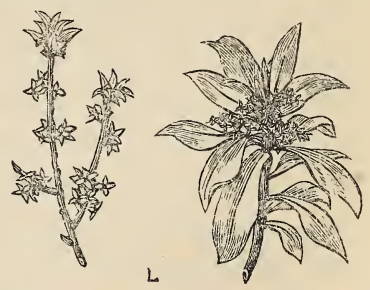

MEZEREON. SPURGE LAUREL. which is the same as what I have described. They also all agree in producing a fine kind of fibrous inner bark. In the plant called the Lace Tree, or Lagetta (Lagetta lintearia), which is a native of 
Jamaica, this inner bark is so like lace, that ruffles, a frill, and a cravat, were cut out of it, and sent as a present to Charles II. The curious little tree called Leatherwood (Dirca palustris) also belongs to this order.

The Laurel or Cinnamon Tribe (Lauracea).

The Sweet Bay (Laurus nobilis) is the true Laurel of the ancients; and it was with branches of this tree that the Roman warriors were crowned after their victories. Into this tree Daphne was fabled to have been changed; and this tree was dedicated to Apollo. In the middle ages it was customary to place wreaths of sweet bay, with the berries on, round the heads of those students who had won prizes at the university; and hence the term bachelor of arts, \&c., from the Latin word for these berries, baccalaureus. These students were so absorbed in their studies, that they had no time to marry; and hence, when a man remained unmarried longer than usual, it was said that probably he was a student or bachelor; and from this the term of bachelor came to be applied to all unmarried men.

The American Sassafras Tree (Laurus Sassafras) forms a large tree. Chips of its wood are steeped in 
water, and the decoction is drunk by persons who have scorbutic diseases, or eruptions on the skin. There are several other kinds of Laurus, natives of America.

The common Camphor Tree (Laurus or Cinnamomum Camphora) is a native of China and Japan, but it is cultivated in many parts of the East Indies. The camphor is the sap of this tree, and it is procured by cutting the branches into small pieces, and throwing them, with the leaves, root, bark, or any part of the tree that may be convenient, into an iron vessel with water, and then slowly distilling them. The steam rising from the wood, \&c., is collected in an earthen vessel stuffed with straw, which is placed as a cover over the iron pot. The camphor rises with the steam and lodges in the straw, from which it is afterwards purified, and melted into lumps for sale. There is another kind of camphor tree, a native of Sumatra, which produces the camphor in large pieces inside its trunk; but as a large tree must be cut down to procure a very small quantity of camphor, it is very dear and but little used.

The Cinnamon Tree (Laurus Cinnamomum, or Cinnamomum verum) is a native of Ceylon. The cinnamon is the inner bark of the small shoots. The 
season for stripping the bark off is from May to October. The whole of the bark is stripped off, but as only the inner bark is the cinnamon, it is tied in bundles without drying, and left to ferment till the outer bark readily peels off, when the remainder is rolled up into quills or pipes about three feet in length, the lesser quills within the larger ones, and in this state it is ready for sale. Camphor is also made from the root of this tree by boiling it, and an oil, used to adulterate oil of cloves, from the leaves ; so that you see almost every part of the tree is made useful. The substance called Cassia bark, which is used to adulterate cinnamon, is the produce of another tree of this genus.

\section{The Pepper Tribe (Piperacece).}

After telling you about cinnamon, I will say a few words about another kind of spice, though certainly a very different one, the common pepper, with which you must all be acquainted. The Pepper Vine (Piper nigrum), a native of the East Indies, is a climber, of no beauty in its flowers, which are produced in long spikes, and are succeeded by the fruit, which is a berry. The black pepper is this berry dried, and the white pepper is made by steeping the berries in water 
so as to deprive them of their skins, and then drying them in the sun. The long pepper is from another

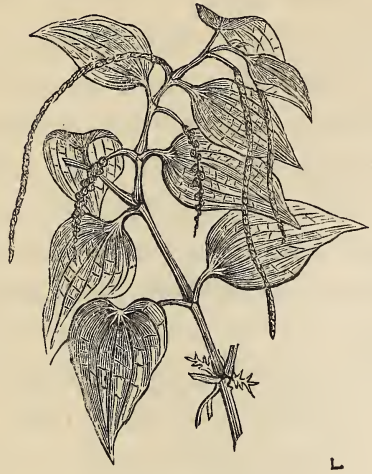

COMMON PEPPER.

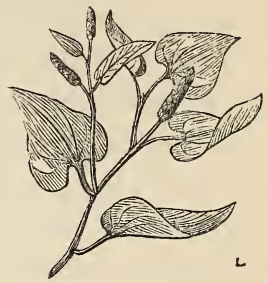

LONG PEPPER.

species of the same genus. The Betel (Piper Betle) is used in the east to chew in the mouth, as sailors do tobacco ; and in Malabar it is reckoned very unpolite to speak to any one without a quid in your mouth.

\section{The Goosefoot Tribe (Chenopdiacea).}

Now let us take a walk in my garden. I want to look at my spinage. I believe I have never before mentioned this plant to you, and so I will tell you 
something about it now. The Spinage (Spinacia oleracea), belongs to the same natural order as the beet, and the goosefoot, and many other common weed-like plants. All these plants have greenish or reddish flowers of no beauty, but their leaves are generally large and handsome. Look at my spinage; it is the Flanders kind; and see what large handsome leaves it has. The stems would be hollow and branching, and the flowers greenish; but I take care not to let my plants produce either flowers or stems, as I want the leaves only.

The Beet (Beta vulgaris) is too large a plant for me to grow in my little garden. I mean, that its leaves take up too much room. It is a native of the sea coast of the Mediterranean. There are several kinds, the red, the yellow, and the white; and the root of the red, as I suppose you know, is eaten, after it has been boiled, either with meat when sliced and vinegar has been poured over it, or in salads. There is one thing curious about the red beet, and that is, that if the root be broken or scraped, or any thing be done to it to break the outer skin, all the colouring matter will boil out of it; and instead of being of the bright beautiful red colour you generally see it, it will be of a nasty dirty white. The Mangel 
Wurtzel (Beta altissima), and the Chard Beet (Beta cicla), are two other species of this genus. The first is much used for cattle, as indeed the common beet is ; and the Chard beet is grown for its leaves, the thick ribs of which, when cut out and boiled, eat like sea kale. Sugar is made from the roots of all these species, but the best is from the white-rooted variety of the common beet. There are large manufactories for making this sugar in France, and I have often seen and tasted it. It is very white, and much crystallized, but it requires more of it to make things sweet than of the common kind.

The Strawberry Blite (Blitum virgatum); the weed called the Fat hen or Goosefoot (Chenopodium album), the Glasswort (Salicornia herbacea), the fleshy stems of which (for it appears to have no leaves,) are often pickled to imitate samphire, and the ashes of which are used in the manufacture of glass; the prickly saltwort (Salsola Kali) the ashes of which yield soda in abundance, and the Garden Orache (Atriplex hortensis) all belong to this order. Those curious flowers called Princes' Feather, and Love-lies-bleeding (Amaranthus hypochondriacus, and caudatus), though they do not belong to the goosefoot tribe, are very nearly allied to it. 
The Buckwheat Tribe (Polygonacece).

I dare say you will be surprised when I tell you that the common rhubarb, the buckwheat, the sorrel, the persicaria, the weeds called knot grass, and docks, and that pretty little red flowering plant, which you have seen in such abundance on the large piece of water in Kensington Gardens all belong to this tribe.

The common tart Rhubarb (Rheum undulatum) is a native of China, and has not been introduced into Europe much above a hundred years. It is the stalk of the leaf which is eaten. About twenty or thirty years ago, this plant was only grown in gentlemen's gardens, and was thought a great rarity; but now above a hundred acres are planted with it in the neighbourhood of London alone. Near Deptford there are large fields of the kind called the Gigantic Rhubarb, the great stalks of which grow so high and bear such immensely large leaves, that if you and I were to be in different parts of the field, we could not see each other.

The rhubarb that you take as physic is the root of a kind with deeply cut leaves, called Rheum palmatum. This plant is a native of Bucharia, and it is 
chiefly cultivated for its roots in Turkey, Tartary, and China. The roots are taken up twice a year, and after they have been cut into pieces of a moderate size, a hole is bored through them, and they are hung up to dry in some shady place.

There are a great many other kinds of rhubarb, the footstalks of the leaves of all of which are eatable, though some kinds are not so good as others; and the roots of all of which may be used as physic.

The Sorrel (Rumex acetosa) is well known for its acid leaves; and it is in common use as a vegetable in France. The common Dock (Rumex obtusifolius) which belongs to the same genus, is a most troublesome weed. Its leaves and stalks are of no use, its long root can hardly be pulled entirely out of the ground, and the abundance of its seeds makes it sow itself, and spread rapidly. You will perhaps wonder how so disagreeable and troublesome a weed came to be classed with so useful a plant as the rhubarb, but if ever you have seen the dock and the rhubarb both in flower and seed, you will see how much they are alike, and why they have been classed in the same natural order.

The British plant called Snakeweed (Polygonum 
Bistorta) is evidently of the same construction as the Garden Persicaria (Polygonum orientale); which differs in its larger and deeper coloured flowers, which are indeed of a bright crimson, and in their being disposed in panicles or bunches of short rounded spikes. The wild persicaria commonly called Redshanks, and the little Water Pepper (Polygonum Hydropiper) are both very pretty; and the Buckwheat (Polygonum Fagopyrum) is the favourite food of pheasants when in seed, and of bees when in flower.

The Marvel of Peru (Mirabilis) though it does not belong to this tribe is nearly allied to it.

The Heath Tribe (Ericacea).

Perhaps there are few plants which convey more agreeable ideas to the mind than the common Ling or Heather (Calluna vulgaris). On the sides of the mountains in Scotland and Ireland, it sometimes forms a bed of close matting extending for many miles together. The stems are recumbent or trailing, repeatedly and irregularly branched. The plant is of slow growth, seldom making shoots of more than three or four inches in one season, even when young; and 
when of five or six years' growth not more than half that length, but it is of great duration. The fine fragrance of the heath, the soft bed it makes in a Highland residence, when an unexpected stranger is in want of a night's lodging, the high flavour it gives the sheep fed upon it, the delicious honey that bees make from its flowers, are all too well known to need repetition. Its little bell-shaped red flowers you must also be acquainted with, but you probably do not know that its seed vessel is so constructed as to retain the seed in it for a whole year. The seeds will also retain their vitality for many years, and on old heath land laid down in grass, plants will often appear, after an almost incredible length of time.

There are a great many different kinds of heath. There is the Tree Heath (Erica arborea) a native of the Pyrenees, where it grows from ten to twenty feet high; and the Cornish Moor Heath (Gypsocallis vagans), which creeps quite close to the ground. The Cape heaths have many coloured globe-shaped, bellshaped, or tube-like flowers; some glutinous, and some smooth, but all beautiful. These plants, which require the protection of a greenhouse in England, are all natives of the Cape of Good Hope, where an 
astonishing number of kinds are found growing in a very small space.

Then there are the Andromedas with their beautiful bell-shaped rosy flowers, which hang their heads like bashful virgins blushing at the admiration they excite ; and the Arbutus or Strawberry tree (Arbutus unedo) covered with bell-shaped, half transparent flowers, that are succeeded by fruit, which look just like ripe strawberries. These are not very good to eat; indeed the name "unedo" which is applied to the tree, signifies once eaten, meaning that if the fruit were eaten once no one would wish to taste it a second time. This tree is a native of the south of Europe, and it also grows wild on the shores of the lake of Killarney, where there are some of the most beautiful arbutus trees in the world. There are several species of this genus, the most interesting of which is the Arbutus Andrachne, which is a native of Greece, and is distinguished from the common kind, by its red bark, which is continually peeling off, and has a very singular effect.

The Rhododendrons are beautiful shrubs belonging to this tribe. Some of these are natives of Asia, such as Rhododendron ponticum; and the Nepal tree 
Rhododendron (Rhododendron arboreum). Here is a sprig of it, with its splendid flowers, which look as if they were made of crimson velvet. There are also some Indian Azaleas. But by far the greater part of both azaleas and rhododendrons come

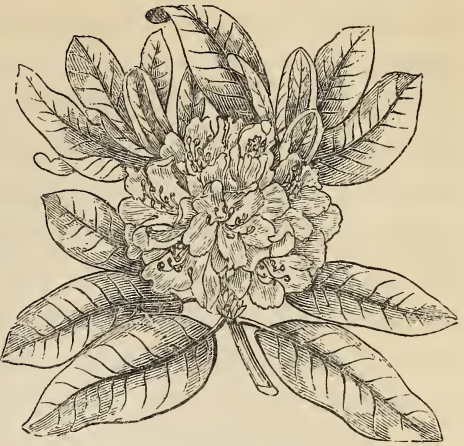

TREE RHODODENDRON. from America, where the woods are rich with them as undergrowth. The Kalmias mix with them, and altogether form the finest mass of flowering shrubs that perhaps the world can produce. Rhododendron Catawbiense, which is one of the American kinds, is so named because it is found in the greatest abundance on the banks of the river Catawba in Virginia.

Have you ever tasted Bilberries or Whortleberries (Vaccinium Myrtillus)? They grow in great abundance on commons in some parts of England and Scotland. Cranberries (Oxycoccus palustris) also grow wild in Scotland and Ireland; but the small cranberries which are sold in London, mostly come 
from Sweden, and the large ones, which are a different species (Oxycoccus macrocarpus), come from America. Cranberries are grown in marshy soil, almost in water; and sometimes in a box of peat earth suspended in water, in which way they produce immense crops.

As almost all the handsome hardy plants of the heath tribe are from America, rhododendrons, kalmias, and azaleas, are commonly called American plants; and when you hear of an American ground at a gentleman's seat, it generally means a patch of bog or peat earth planted with these shrubs. At High Clere in Berkshire, and some other places, these shrubs are sown in the woods, and present in England the richness of an American spring. The Epacris is a pretty heath-shaped flower nearly allied to this tribe, though it is not included in it.

\section{The Primrose Tribe (Primulacece).}

What flower can be more beautiful than the common Primrose (Primula vulgaris) when it covers whole banks in a shady wood, with its beautiful pale yellow flowers glistening amidst its thick mass of leaves? There are double lilac primroses, and double white, double straw colour, and double scarlet, but I do not think any of them superior to the little modest 
flower, which forms so great an ornament to the English woods in spring.

There are many other well known flowers belonging to this genus. There are the Oxlip (Primula elatior), the Cowslip (Primula veris), the Chinese Primrose (Primula prænitens), and the Auricula (Primula auricula). But where you will ask is the Polyanthus? Does not that belong to the primrose tribe? It does, and it is generally supposed to be a variety of the common primrose, though some fancy it a variety of the oxlip. From the name I should think it belongs to the former. The common primrose sends up its flowers singly, and the polyanthus has a great many on one footstalk. Hence the name of polyanthus, which signifies many-flowered, seems well given to distinguish it. Besides if you take a common primrose, and water it with liquid manure, the flowers will gradually turn reddish. In whatever way the polyanthus originated, it is now a very common flower; and there are a very great number of sorts, which have been raised by florists. The most beautiful have a rich dark centre, and a clear yellow margin. The more clear and distinct these colours are, the more beautiful the flower is esteemed.

The auricula is also a florists' flower. I cannot 
pretend to tell the names by which the different kinds are distinguished, but I can tell you the principal divisions. These are grey edged, green edged, white edged, and self. The first three kinds explain themselves, but the last may not be generally understood. It means all of one colour, or rather of different shades of one colour. These self-coloured auriculas are not reckoned so valuable as the other kinds.

Among the other plants belonging to the primrose tribe are the Cyclamens, with their blotched leaves, curious pink flowers, and still more curious seeds. Some of these are natives of the south of Europe, some of Persia, and one, the Ivy-leaved, of England. I do not think there are any natives of America, at least I never heard of any. The common name of cyclamen is sow bread; because in Italy the wild swine almost live upon its bulbs. When the flowers of the cyclamen fade, the footstalks will themselves close up to the ground round the seed pod, as though to take care of it, till the seeds are ripe, when the pods burst and scatter them abroad. The seeds however are a long time before they produce flowers ; as the bulb of the cyclamen, like other bulbs, is said not to flower till it is five years old. 
The American cowslip (Dodecatheon Meadia), the Soldanella, the Lysimachia or Loose-strife with its yellow flowers, and the Anagallis or Pimpernel, all belong to this tribe. Moneywort (Lysimachia Nummularia) is a trailing plant with bright yellow flowers, which, when planted in a pot, and left to hang loosely down over the brim, or among rock work, has a very pretty effect. The wild pimpernel (Anagallis arvensis) has been called the shepherd's weather glass, because it never opens its flower when it is likely to rain. It is also one of the flowers used for making the floral clock, as it opens every morning in dry weather at seven o'clock, and closes at two in the afternoon.

\section{The Bindweed Tribe (Convolvulacea).}

The wild Convolvulus of the hedges, or Bindweed, (Convolvulus or Calystegia sepium); and the little pink convolvulus of the fields (Convolvulus arvense) are two of the prettiest of the British native flowers. The first of these, and most other plants belonging to this order, have twining stems. You know the shape of the flower of the convolvulus, and no doubt have seen how curiously it is folded up in the bud, or when the convolvulus does not choose to expand 
its beauties to the day. The different parts belonging to this tribe are rather capricious in this particular, as some only open their flowers at night, and others only in the day. But they are all so beautiful that we are glad to see them at any hour.

One of the kinds of convolvulus is the plant which produces jalap. This medicine is made from the root, and it is a very violent purgative. The sweet potatoe (Convolvulus Batatas) is another kind. It was from the word Batatas that the name of potatoe was taken; and this kind was in general use, long before the now common potatoe was discovered in America. It is amusing to read what some of the old writers on plants say on this subject. They treat the Virginian potatoe, as it was called, merely as a novelty, and consider it not worthy of being compared to the batatas.

The Ipomæa is an extremely beautiful flower, so like the convolvulus in shape that you would scarcely know the difference. It is, however, very different in hardiness ; for it requires to be nursed as a greenhouse or hothouse plant. I had a beautiful plant of ipomæa rubro-cærulea, in a pot, under my veranda, which opened three or four of its large and beautiful blue flowers every morning, and though they only 
lasted a day, they were almost as handsome, after they closed and begun to fade, from the beautiful pink that they became, as they had been when they were fully expanded.

One of the plants belonging to this order, is so very curious in its appearance and habits that I must tell you something about it. It first appears rising from the ground near the stems of heaths, or furze, or some other wild plant on a common, and looks like clusters of reddish cords curiously twisted together. It then curls itself round the plant at the foot of which it had lain, and as soon as it is firmly settled there, it detaches itself from the ground and hangs on the plant round which it had intwined itself, till killed by the first frost. This strange plant is called the Dodder (Cuscuta europæus).

The Greek-valerian Tribe (Polemoniacece).

This order contains some of our most ornamental garden flowers. There is the Phlox, with all its numerous species and varieties, the most beautiful of which is the brilliant Phlox Drummondi; the Leptosiphon, the Gilia, and all its different kinds, of which, Gilia tricolor is, I think, the prettiest; Ipomopsis, with its splendid flowers; and lastly that 
magnificent climbing plant the Cobæa, the flowers of which are so beautiful.

\section{The Lobelia Tribe (Lobeliacece).}

It is remarkable that the principal genus of this tribe includes the most delicate little flowers; such as Lobelia erinoides, which is of so delicate and beautiful a blue, and with such slender and fragile stems, and the Lobelia cardinalis which is a tall stronggrowing plant with large coarse leaves, and flowers of the most brilliant scarlet. Most of the lobelias are natives of the Cape of Good Hope, and South America. The Cardinal flower (Lobelia cardinalis) is a native of Virginia, from which country it was brought to England about the year 1628; and as soon as it flowered, it was presented to Henrietta, queen of Charles I. Her Majesty, it is said, exclaimed, on seeing it, that it was a brave flower, and begged that it might be called the Cardinal flower, because it was just the colour of the cardinal's stockings—and so, the Cardinal flower it was called. The name of Lobelia was afterwards given to this genus in honour of Mathias L'Obel, a learned Fleming, who was appointed botanist and physician to James I. of England; for in those days, plants were little re- 
garded, except for their medical properties, and few persons were botanists, who were not physicians.

\section{The Campanula Tribe (Campanulacece).}

Among the numerous plants belonging to this order, perhaps one of the best known is Venus's Looking Glass (Campanula or Prismatocarpus speculum). It is a pretty, low-growing, bell-shaped, purple flower, which has been sometimes found wild in Kent; and it is said to be called Venus's lookingglass, from the somewhat mirror-shaped form of the flower. In floral language it stands for flattery.

The Pyramidal Bell flower (Campanula pyramidalis) is a splendid plant when properly trained. This plant, in floral language, is made to signify gratitude; because it so amply repays the trouble taken to manage it. The little Bluebell of the hedges (Campanula rotundifolia) is one of our prettiest wild flowers. The common name of this plant is the Bluebell, but it is often called the Harebell, particularly in poetry ; there is another plant called the harebell, and in some parts of England also the bluebell, which is a kind of wild hyacinth. The Canterbury Bell (Campanula Medium) is a native of Germany, but it has been grown in English gardens for more 
than two hundred years. The Blue Throatwort (Trachelium cæruleum) also belongs to this order, and is a very handsome plant. It is a biennial, and is a native of Italy. All the plants belonging to this tribe exude a milky juice when they are broken. Most of them have bell-shaped flowers, in which the petals appear all joined together; but in others the petals are quite distinct.

\section{QUESTIONS.}

1. What are the qualities of the Mezereon tribe? 2. What is peculiar in the flowers of this tribe? 3. What tree was the Laurel of the ancients? 4. What tribe does the common Camphor tree belong to? 5. What tribe does the Cinnamon tree belong to? 6. What part of the tree is the cinnamon? 7. What kind of plant produces pepper? 8 . What tribe does the Beet belong to? 9. What tribe does the Rhubarb belong to? 10. What country do the Greenhouse Heaths come from? 11. What country produces most of the Rhododendrons, Azaleas, and Kalmias? 12. What plant produces jalap?

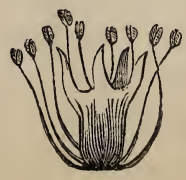




\section{CHAP. XXI.}

JESUIT'S BARK, OR QUINQUINA. THE COFFEE TREE. IPECACUANHA. THE HONEYSUCKLE TRIBE. SNOWBERRY, THE JASMINE. ELDER TREE. LAURUSTINUS AND GUELDER ROSE. VIPER'S BUGLOSS. FORGET-MENOT. THE COMPOSITE. THE NIGHTSHADE TRIBE. TOBACCO. THE POTATOE, THE LOVEAPPLE OR TOMATO, AND THE EGG PLANT. THE MINT TRIBE. VERBENAS. SNAPDRAGON AND FOXGLOVE. THE OLIVE TRIBE, THE ASH TREE, THE MANNA ASH, AND THE PERIWINKLE.

\section{The Coffee Tribe (Cinchonacece).}

THis is a most important order, as it contains some valuable plants. The Coffee tree (Coffea arabica) is one of these; the Peruvian Bark, or Quinquina, which is so much taken in medicine, is another; and Ipecacuanha, which is made from the root of Cephaelis Ipecacuanha, a little creeping half herbaceous plant, found in damp shady forests in Brazil.

The Peruvian Bark, or Quinquina (Cinchona scrobiculata) is, as the name imports, a native of Peru. It is said to have been first discovered about two hundred years ago, by a Spanish Jesuit. This man 
had the habit of breaking off little bits of trees, and chewing them in his mouth, and he discovered that the bark of this tree was extremely bitter. Soon after, this Jesuit suffered severely from a kind of ague, and as he knew that the strengthening medicines called tonics, which were given in similar cases in Europe, were very bitter, and as he could not get any of these medicines in South America, he was determined to try an infusion of this bark. He did so, though it might have been poison, as strong bitters frequently are; but it so happened that it was a tonic, and just suited to his complaint. Shortly after this,

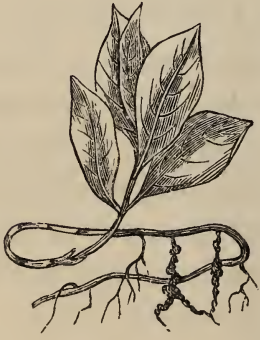

IPECACUANHA.

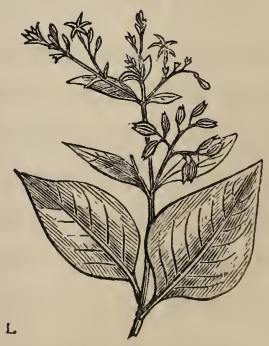

PERUVIAN BARK.

the Countesa Chinchon, vice-queen of Peru, was seized with the same kind of ague, and the Jesuit, 
who was acquainted with her confessor, recommended him to advise her to try this new remedy. The countess did so, and was cured. Of course the bark soon came into fashion, and it was named Cinchona after the lady, and Jesuit's Bark after the Jesuit. I do not know whether this tale be true or not, but it is what is generally told on the subject.

The bark is taken off the tree, nearly in the same manner as the cinnamon bark is stripped off; and it is dried in the sun as quickly as possible. The greatest care is taken to shield it, while drying, from the dew, as the slightest damp changes the bark black. There are a great many kinds of cinchona, all of which produce tonic bark, but the kind I have told you about is the most common.

The Coffee plant (Coffea arabica) is an evergreen shrub, with shining leaves, and fragrant white flowers. The fruit is a berry which is red at first, but afterwards becomes purple. The part we use for making coffee is the bean or seed, and of these seeds there are two in each berry. When the fruit is ripe, the pulpy part of the berry begins to shrivel. The berries are then gathered, and placed in the sun to dry. They are afterwards passed between wooden rollers to 
separate them from the husks, and are then sifted, winnowed, and put into casks for sale. The coffee beans are of a greenish tinge, and before they are ground, they are roasted by putting them into a round iron vessel, and turning it backwards and forwards over a clear fire, till the beans get of a light or chestnut brown. They must be then taken out of the iron vessel immediately (or they will get black), and cooled be-

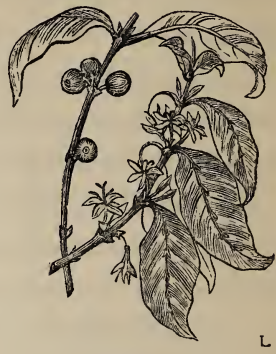
COFFEE TREE. fore they are ground. Coffee is much taken by studious persons, as it is said to have a great effect in clearing the brain.

The coffee plant is a native of Persia, and from that country it was introduced into Arabia about the middle of the fifteenth century. In 1554 the first coffee houses were opened in Constantinople. From that country it spread gradually through Europe. It did not reach Paris, however, till 1660 ; and a few years afterwards it was introduced into England by Daniel Edwards, a Turkey merchant, who having a Greek servant, named Pasque Roffee, who under- 
stood the roasting and making of coffee, set up a coffee shed in the churchyard of St. Michael's, Cornhill. This was the first coffee house in England.

The taste for coffee having increased the demand for it, the Dutch, who were always mindful of their own interest, contrived to obtain some coffee plants from Persia, and to plant them near Batavia, and in their other settlements in the East Indies. Plants were afterwards sent to the West Indies, where large plantations have been formed, and whence most of the coffee drunk in England is imported. Great quantities are also imported from Brazil. In making the plantations the coffee plants are raised from seed, and afterwards arranged in rows. They require great heat, but at the same time do not thrive unless they have abundance of moisture and shade. For the latter purpose, trees with large leaves are often grown in the coffee plantations, and these trees are called the coffee mammas. It requires a large plantation to yield only a moderate quantity of coffee, as scarcely any plant produces more than two pounds of coffee, and very few even so much.

The Honeysuckle Tribe (Caprifoliacec). The common Woodbine of the hedges (Caprifolium 
Periclymenum) has been often celebrated by poets. It is one of the sweetest ornaments of English woods ; and twining round a pole, or over a trellis in a garden, it is highly ornamental. It is, however, injurious to trees when twined round them, as it buries itself in their trunks, and impedes their growth. The Dutch Honeysuckle, and the late red, are varieties of the common woodbine. The Japan Honeysuckle (Caprifolium japonicum), or Gold-and-silver plant, has its flowers half yellow and half white. The Evergreen Honeysuckle (Caprifolium gratum) is one of the hardiest and most constant flowering species. It is a native of North America. The Trumpet Honeysuckle (Caprifolium sempervirens) is also a native of America, and it is a very beautiful flower, from its being a deep scarlet. The Chinese Honeysuckle (Caprifolium or Lonicera flexuosum) is delightful for its fragrance. All the twining honeysuckles are sweet, but this is the sweetest. It twines round my veranda ; and when I come home at night, after having been out all day, and I am fatigued and exhausted, if I smell this sweet flower at a distance, as I am toiling wearily along the road, I feel revived and strengthened, for that delicious fragrance brings with it the idea of home. 
All the twining honeysuckles twine from east to west. They follow in their course the sun. But there are other honeysuckles which do not climb or twine; that are stiff, upright plants, and that have no fragrance. These are called Fly Honeysuckles, and the commonest of them is called Lonicera Xylosteum. There are several other kinds of lonicera; such as the Tartarian Honeysuckle, a kind with red berries (Lonicera alpigena), one with blue, one with black, and one with white. All these have not their flowers in bunches like the twining honeysuckles, but two little flowers grow together at the end of each twig.

The Snowberry (Symphoria racemosa) belongs to the same order; and in fact the flowers are very much like those of the Tartarian honeysuckle. It is a native of North America; and is sometimes called St. Peter's-wort. You will perhaps be surprised to find that the elder belongs to the same natural order. The common Elder (Sambucus nigra) is a low tree, with black berries, and white flowers, which have a most unpleasant smell. It grows wild in Britain, and throughout Europe and Asia. There is a variety of it with cut leaves. The American Elder (Sambucus Canadensis) is a shrub from four to six feet 
high, the flowers of which have scarcely any smell; but the Spanish Elder (Sambucus racemosus), which has red berries, is the handsomest of the genus.

The Laurestinus (Viburnum Tinus) is the next plant I shall tell you about. It is a native of the south of Europe and north of Africa; and it is a very valuable plant in the London gardens, because it flowers all winter. There is a kind with shining leaves, which is more tender than the common kind. The other kinds of viburnum are so different from the laurestinus, that you would not think that they belonged to the same genus. The Tree Viburnum (Viburnum Lentago); the Wayfaring tree (Viburnum Lantana), and the Guelder Rose (Viburnum Opulus), are the most remarkable of these. This last has a very pretty effect in a shrubbery, and it is sometimes called the Snow-ball Tree, from its snow-white balllike flowers. The name of Guelder Rose is supposed to be taken from the garden variety of it having been first grown in Belgium in Guelderland.

\section{The Madder Tribe (Stellata).}

This order includes several well known British plants, among which I may mention the Bedstraw (Galium 
verum), the Sweet Woodruff (Asperula odorata), and the Madder (Rubia tinctoria). The flowers of the Bedstraw are sometimes used in the country to make curds and whey; but this is only when the proper rennet (which is the dried stomach of a calf) cannot be procured. The seeds of the bedstraw, when roasted, taste something like coffee. The woodruff is so very sweet, that the country people dry it, and put it into their drawers like lavender, to scent their linen; and the madder is used for dying scarlet. This last plant is a native of the south of Europe, but it is cultivated in many countries for its roots. These are taken up in September and twice dried in a kiln. They are afterwards cleaned and ground, or pounded in a mill, to make them yield their rich dye.

\section{The Borage Tribe (Boraginacece).}

The Viper's Bugloss (Echium vulgare), and the garden flower Phacelia tancentifolia, will give an idea of the curious manner in which the flowers of plants belonging to this order are disposed. They grow in a sort of coil, and in these plants they are disfigured by the long hairs which surround them. The Hound'stongue (Cynoglossum), the Lungwort (Pulmonaria), the Comfrey (Symphytum), and the common Borage, 
all belong to this order. Besides these, there is the Gromwell (Lithospermum), the Latin name of which signifies a stony seed, from its seeds actually looking like little stones. The Alkanet root (Anchusa tinctoria) is another of these plants ; but the most interesting is the Forget-me-not (Myosotis palustris).

Have you ever heard the legend of this pretty flower, and how it obtained its name? One day, the story tells us, two young people who were soon to be married were walking together on the banks of the Danube, when the lady saw one of these beautiful blue flowers just peeping above the water. It was the only one the blossoms of which had expanded, and the lady tried to reach it; but it was too far distant. Her lover, seeing her wishes, bastily bent over the water, but just as he reached it his foot slipped, and he fell into the stream. Unfortunately the river in that part was very deep; and there was a strong current, which, in spite of his efforts, carried him down the water. In vain he struggled, in vain his distracted bride called for assistance-his fate was sealed-once more he rose, he cast a desponding look towards the unhappy girl, and exclaiming, " Forget me not!" sank back, and the waters closed over him for ever. 
The Compound-flowered Plants (Compositce).

All the plants belonging to this order have compound flowers; that is, what we are accustomed to call the flower is in fact a flower head, composed of a cluster of little flowers or florets. For example, the flower of the daisy, that of the French marigold, and that of the dandelion, are all composed of a number of compound flowers, forming what is called a ray, and fixed round a centre called a disk, also composed of flowers, but of flowers of a different kind to those in the ray. All these flowers are called compositæ, because they are composed of many other flowers, and they are divided into other sections, according to some other points which they have of resemblance.

One of these sections consists of the succory-like plants. This division contains the Lettuce (Lactuca sativa), the Endive (Cichorium Endivia), the Salsify (Tragopogon porrifolius), the Scorzonera hispanica, or Spanish Viper's Grass, the Sow Thistle (Sonchus oleraceus), the Hawkweed (Hieracium), the Chicory (Cichorium Intybus), the Dandelion (Leontodon Taraxacum), and many others. All these, when the stem is broken, give out a milky juice, and they are all eatable ; many of them are, indeed, in constant use 
for the table. Besides the milky juice, they are botanically distinguished by their florets being all what is called ligulate, that is, tube-shaped at the bottom, but looking as though part of the mouth of the tube had been torn off. In all the compositæ, the ray of the flower head is composed of flowers of this kind; but in the succory-like plants, all the florets are of this shape, and there is no distinction between the ray and the disk.

The next division is of the thistle-like plants. This section comprises all the Thistles (Carduus), the Blue-bottles (Centaurea), the Artichoke (Cynara Scolymus), and many other plants. The choke of the artichoke is in fact a collection of florets, separated from each other by numerous stiff hairs, which grow out of the part called the artichoke bottom, but are separated from it by boiling. The flowers in this division are composed entirely of tubular florets like those of the disk, where the ray and the disk are distinct; so that if the succory-headed flowers were all ray, the thistle-headed flowers may be called all disk.

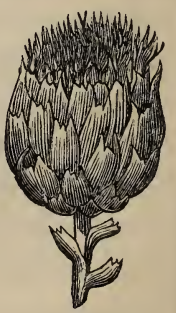

ARTICHOKE IN FLOWER. The third section is by far the most numerous, and 
it is composed of all the flowers which, like the daisy, have both ray and disk. You will see the difference between these florets strongly marked in the sunflower, in which their shape is marked more distinctly than in so small a flower as the daisy. This is the Radiate section (Corymbiferæ), and it con tains the common Daisy (Bellis perennis), of which the Hen and Chickens Daisy is a variety; the Sunflower (Helianthus annuus); the Jerusalem Artichoke (Helianthus tuberosus); the Asters, the Chrysanthemums; the common Marigold (Calendula officinalis); the French Marigold (Tagetes patula); the African Marigold (Tagetes erecta); Wormwood (Ar temisia Absinthium); the Southernwood (Artemisia Abrotanum); Elecampane (Inula Helenium); the Dahlias; Coltsfoot (Tussilago Farfara); Groundsel (Senecio vulgaris); Chamomile(Anthemis nobilis); the different kinds of Everlasting (Helichrysum, Gnaphalim, and Xeranthemum); and thousands of others.

\section{The Nightshade Tribe (Solanece).}

This contains the Deadly Nightshade, the Henbane, the Tobacco, and the Potato, besides many other interesting and well known plants.

The Deadly Nightshade (Atropa Belladonna) is 
a plant with very large leaves, and livid purple bellshaped flowers, which are succeeded by shining black berries. These berries are poisonous, and act by stupifying. It is said that when a Danish army invaded Scotland, several centuries ago, the Danes ate of these berries, mistaking them for fruit, and became so completely stupified, that a large army was destroyed by a few Scotch peasants.

The Mandrake, about which so many strange tales have been told, is another species of the same genus (Atropa Mandragora). This plant has a curiously shaped root, forked so as to resemble two legs, a body, and sometimes arms; and from this circumstance it was anciently supposed to be half a man and half a plant, and it was said to shriek when it was drawn out of the ground. People, taking advantage of this story, pretended to show mandrake roots as a great curiosity; and because they would not always grow in the proper shape, an ingenious plan was contrived of forcing the root of the black bryony, which is very flexible and very tenacious of life, into an earthen mould, so as to make it take any figure that might be wished; I have seen one that exactly resembled two children; and these roots they took about and sold as great natural curiosities. The 
mandrake has white flowers veined with purple, and scarcely any stem.

The Henbane (Hyoscyamus niger) is a native of Britain, and is generally found growing wild on heaps of rubbish or banks near old towns. Its leaves are broad and hairy, and they have a very disagreeable smell. The flowers are of a yellowish white veined with purple. The Thorn Apple (Datura Stramonium), the elegant garden flower called Datura Metel, and the superb Brugmansia (Datura arborea, or Brugmansia suaveolens), all belong to this order; and the last is one of the most splendid plants grown in England. Its long tube-like flowers, their snowy whiteness, and delightful fragrance, combine to make it a most valuable plant in an ornamental point of view, though I have never heard of its being applied to any use.

The Tobacco (Nicotiana Tabacum) is another plant belonging to this order. It is grown for its leaves, which are used for making tobacco and snuff. It is cultivated for this purpose in America, of which country it is a native, and the West Indies. It is planted in rows, and when the leaves are fully grown and ripe, which is known by their becoming brittle, the whole plant is cut off with a knife close to the ground, and taken to the drying shed. The plants 
are then tied together in pairs, and hung up to dry upon lines stretched across the shed. When sufficiently dry, the leaves are stripped off the stalks, and made into small bundles, which are placed in a heap to heat, the heap being covered with blankets. When no more heat is perceived in the heap, the bundles are ready to be packed in casks. Before the tobacco is used, the bundles are opened, and

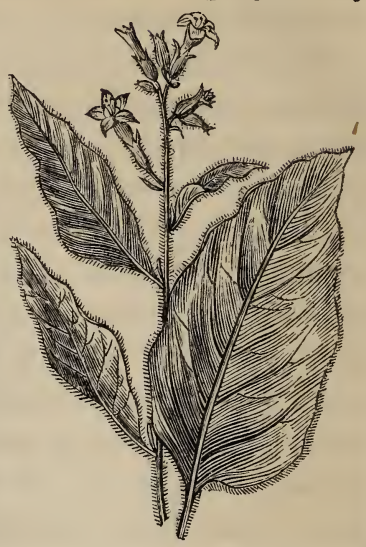

товассо.

the leaves moistened with salt and water. Some of the leaves are then made into cigars, by drying them before a fire, and rolling them in a mill round a stick; and other leaves are cut into small pieces with a fixed knife, and then spun in cords; this is for making what are called quids of tobacco, which sailors are so fond of chewing. Other leaves are formed into large rolls, which the tobacconists cut into small pieces for smoking, or dry and grind into a powder, which is called snuff.

There are many kinds of tobacco, but the com- 
monest is the Virginian tobacco, which I have already told you about, and which has pink flowers. The other kinds have some of them white flowers, some green, and some scarlet, and their leaves make different kinds of tobacco; something also depends on the manner of drying; but all kinds of snuff, cigars, and tobacco, are made from some species or other of the genus Nicotiana.

You have no doubt heard the story of Sir Walter Raleigh, who first brought the tobacco from Virginia, and who, having but little of it, used to smoke it privately. One day his servant came unexpectedly into the room, and seeing fire and smoke coming out of his master's mouth, he thought he was on fire, and happening to have a vessel full of water in his hand, he threw the water on his master to put him out! The beautiful Petunias are nearly allied to the tobacco, and belong to the same natural order.

The Potato (Solanum tuberosum) was also introduced by Sir Walter Raleigh, and, as I told you when speaking of the convolvulus batatas, it was at first thought very inferior to that root. By degrees, however, its excellence has been generally acknowledged every where, even in France, where I remember the time when they said potatoes were only 
fit for the English and the pigs. The flower of the potato is rather pretty, and its fruit is what is called the potato apple, and is poisonous. The tubers form themselves by degrees in the ground, and the real roots are the little fibres attached to them. The Bitter-sweet of the hedges (Solanum Dulcamara) is very nearly allied to the potato, and its red berries are poisonous. The Tomato or Love Apple (Solanum Lycopersicum), and the Eggplant or Aubergine (Solanum Melongena), both bear fruit which is eaten when cooked, but which would be injurious in a raw state.

\section{The Mint Tribe (Labiata).}

This order contains nearly all those sweet smelling herbs which are so useful in our kitchens: the Thyme (Thymus vulgaris), the Marjoram (Origanum vulgare), the Balm (Melissa officinalis), the common Horehound (Marrubium vulgare), the Mint (Mentha viridis), Peppermint (Mentha piperita), Pennyroyal (Mentha Pulegium), and Sage (Salvia officinalis). Besides these, there are the Rosemary (Rosmarinus officinalis), the Lavender (Lavandula Stæchas), and many others. There are also many beautiful flowers belonging to this order, particularly the ornamental 
kinds of salvia. If you have ever seen the flower of the common sage, or of the Dragon's Head (Dracocephalum), these two plants will give you an idea of the shape of all the flowers belonging to this order.

\section{The Vervain Tribe (Verbenacea).}

Have you ever seen the beautiful scarlet Verbenas that grow in pots, and sometimes in the open air? They are mostly natives of South America, but the common vervain grows wild in Britain. This plant was used by the Druids in their sacrifices, and was worn even within the last century as an amulet or charm against an evil eye. There are purple, yellow, and white ornamental verbenas, as well as scarlet, and they are all very beautiful. The sweet scented vervain used to be called Verbena tryphylla, but botanists have now changed its name, and call it Aloysia citriodora. You will be surprised to find that the East Indian timber tree, the Teak (Tectoria grandis), belongs to this order.

\section{The Figwort Tribe (Scrophulariacea).}

The Mullein or Flannel Plant (Verbascum pulverulentum), which has yellow flowers, is one of the handsomest of the native British plants. It grows 
quite erect, and from three to six feet high, forming a pyramidal spike of yellow flowers. The Purpleflowered Verbascum (Verbascum phœnicium) is also a very handsome plant. Many well known flowers belong to this order: the Snapdragon (Antirrhinum majus), the Calceolarias, with all their numerous and beautiful varieties, the Toadflax (Linaria), the beautiful climbing plants Maurandya, Lophospermum, and Rhodochiton; the Collinsias; the Schizanthus, Salpiglossis, and Penstemon; the Foxglove (Digitalis purpurea); the Musk Plant (Mimulus moschata); the Veronica ; and Scrophularia, or Figwort, from which the order takes its name. The Snapdragon and the Foxglove will give you an idea of the general shape of plants belonging to this order; but there are several of very different and very curious shapes, such as the Schizanthus and the Calceolaria.

The Olive Tribe (Oleacece).

The principal use of the Olive is to make oil, but the fruit is pickled in salt and water, and eaten after dinner to give a relish to the wine. I do not like it, and I do not think you would; but people who are accustomed to take a great deal of wine, lose the 
fineness of their taste, and require something of very strong flavour. The leaves of the olive tree are of a bluish green, something like those of the willow. I do not think that they are at all pretty. They grow in great abundance in the south of France and Italy, and also near Athens, in Greece. An olive plantation is very monotonous, that is, nearly the same in every part; and as the greyish green leaves wave to and fro, they have a dull and almost sleepy look. Some people admire them, but I only tell you what I think. The olive takes root as easily as the mulberry or the willow, and if you stick a branch in the ground in rather moist soil, it will be sure to grow.

The Privet (Ligustrum vulgare), the Phillyrea, the American Snowflower or Fringe Tree (Chionanthus Virginica), and the common Lilac (Syringa vulgaris), all belong to the same order as the olive; as does also the Ash.

The common Ash (Fraxinus excelsior) is one of the most elegant of the native British trees; and the weeping variety is still more so than the common kind. Manna is a substance which exudes from the Flowering Ash (Ornus europæa). It is only in hot countries and in hot weather that it is produced, and it oozes out of the bark like a clear liquid, which 
soon thickens, and is scraped off. This is the best kind of manna, but as there is very little of it, a more expeditious way of procuring it has been devised. This is done by piercing the trunk, and fixing a slender twig or piece of straw, which the manna runs down and cakes over. This is the reason that the common manna of the shops is tube shaped. There is another kind of manna, the produce of a plant called Alhagi Maurorum, which is a native of Arabia, but so little of it is produced, and it is so dear, that it is seldom sent to Europe.

The common Jasmine (Jasminum officinale) has white flowers of most delightful fragrance. It is a climbing shrub, a native of Asia, and rarely ripens its seeds in this country. The yellow Nepal Jasmine (Jasminum revolutum) is also a beautiful climbing shrub. The Sambac or Indian Jasmine (Jasminum Sambac) only gives out its fragrance at night, but it is sweeter than all the rest.

The Periwinkle (Vinca major) does not belong to this order, but it is nearly allied to it. The Italians call this plant Hundred Eyes, because its beautiful blue flowers peep out from among its evergreen leaves like eyes. This plant, in the language of flowers, is consecrated to agreeable recollections, because Rous- 
seau saw it for the first time when in company with a very dear friend. He was then young. Fifty years passed away, and he had become old, when one day, climbing a hill, he saw this plant. "Ah, there is the periwinkle," cried he, and, forgetting all the infirmities of age, he ran to it and kissed it. Time, sorrows, all were forgotten, and the feelings of youth returned vividly at the sight of that plant. For this reason the French consider the periwinkle as the emblem of tender remembrances.

The Gentian is also nearly allied to the Oleaceæ, as is also the Periploca, though neither of them belong to it. The periploca is a climbing plant, with very dark brownish purple flowers, which has the singular property of destroying flies. Under a bower covered with a plant of periploca, there were found hundreds of flies lying dead.

\section{QUESTIONS.}

1. What are the principal plants belonging to the Coffee tribe? 2. What are the three great divisions of the Compositæ? 3. What are the most important plants belonging to the Nightshade tribe? 4. What are those of the Mint tribe? 5. What tree produces salad oil ? 6. What tree produces the common manna? 


\section{CHAP. XXII.}

THE SCOTCH PINE; THE SPRUCE FIR; THE SILVER FIR, THE LARCH, THE CEDAR OF LEBANON, AND THE DEODARA. THE CYPRESSES. THE WHITE AND RED CEDARS. THE ARBOR VITÆ. THE JUNIPERS. THE YEW AND THE SALISBURIA. DISTINGUISHING MARKS OF THE DICOTYLEDONOUS PLANTS.

\section{The Pine and Fir Tribe (Coniferce).}

Of all the cone-bearing trees perhaps none are more generally useful than the Scotch firs, or pines, as they are more properly called. From these trees come all the deal used in building houses, for making boxes, and in short for so many purposes, that, with the exception of ship building, I think deal is more generally useful than oak; and deal is the timber of the Scotch Pine (Pinus sylvestris). There are enormous forests of this tree in different parts of the world, but the largest are in Sweden and Norway, and in Prussia, Russia, and Poland. There are very large forests also in Canada; and from all these countries deal is sent to England. The Scotch Pine also grows wild in Scotland, and there are forests of 
it in the Highlands. In the United States there are immense forests of pines and firs on poor, dry, sandy soil where nothing else will grow, and these forests are called pine barrens. The pine forests stretch as far as the eye can reach, day after day, as the traveller proceeds, till they absolutely seem interminable. I have travelled above five hundred miles through these forests ; only occasionally meeting with a kind of village of $\log$

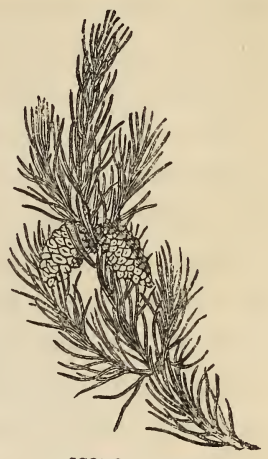

SCOTCH PINE.

houses among the trees, inhabited by wood cutters.

When the trees in pine forests are cut down, they are sometimes dragged through the woods as I described the mahogany trees, that I told you about before; and sometimes they are tied together and floated down the rivers like rafts ; and in Switzerland, where some pine trees grow on the side of a lofty mountain amid many rocks and valleys, a kind of inclined plane was contrived, which was called the slide of Alpnach, which extended from the summit of Mount Pilate to the Lake of Lucerne, a distance of above eight English miles. This slide consisted of 
a great trough, formed of twenty-five thousand pine trees, wide enough to admit a large tree, and six feet deep. In order to preserve its regular slope, this great slide had to be conducted sometimes over rocks, sometimes over valleys, on strong scaffolding raised to support it, and sometimes through tunnels. The slide was kept constantly wet to prevent it from taking fire by the rapidity with which the trees passed along it; and this was so great that a gentleman who stood beside one part of it, declared he could only strike the largest tree with a stick once, as it rushed by, however quickly he tried to repeat the blow. A tree a hundred feet long took only six minutes to run the whole eight miles and a half.

Deal is not the only useful production of the pine and fir tribe. They all yield turpentine, tar, pitch, lamp black, \&c. Common turpentine is the produce of the Scotch pine, Strasburg turpentine comes from the silver fir, and Venice turpentine from the larch.

To procure the turpentine from the Scotch pine an incision is made in the tree; a deep notch cut in the part near the root, so as to form a kind of bason, and the bark is stripped off from the incision to the notch. The resinous matter soon begins to run, and as fast as the notch becomes full it is emptied with 
small ladles, and the matter it contained is put into baskets, which are set over stone or earthenware jars. The fluid part which runs into the jars is the turpentine, and the solid part which remains in the basket, when purified by boiling, is the common yellow rosin. Oil of turpentine and spirit of turpentine are distilled from the raw turpentine; and what is left after the distillation is the common black rosin or colophony which players on the violin use to resin their bows. Tar is made by cutting the wood and roots into small pieces, and burning, or rather, charring them in a close oven, or heap covered with turf through which the tar runs in the form of a thick black fluid. The Swedish tar is the best, and the American the worst. The reason is that the Swedish tar is made from wood just cut down; whereas the American tar is made from dead wood picked up in the forest. Lamp black is the soot that rises from the wood while it is burning to make the tar; and pitch is tar boiled till it becomes quite dry. The yellow rosin is used in making the common coarse yellow soap, in the proportion of three hundred weight of rosin to ten hundred weight of tallow; and shoemakers' wax is made of pitch, oil, and suet. Many other useful articles are made from the produce of the pine and fir tribe; but what I have 
mentioned will be sufficient to show you the great usefulness of these trees.

There are a great many different kinds of pines; all of which have long narrow leaves, produced in little bunches of two, three, four, or five in a sheath. This sheath is a little bit of white skin, and the root of each bunch or bundle of leaves is enclosed in it. The Spruce Fir (Abies excelsa), on the contrary, has its leaves short and broad; and if you examine them closely you will find that they have no smooth upper side, but consist of two leaves glued together so as to show only their under sides. So that the leaf of the spruce fir has the mid rib sticking out on both sides, while all other leaves have it sticking out only on the under side. The cones of the spruce fir also always hang down.

The spruce fir is called Abies excelsa, which signifies the tall spruce fir, with great propriety, for it is the tallest of European trees. It grows frequently from a hundred and twenty to a hundred and fifty feet high, and sometimes to a hundred and eighty feet. This is far short of the eucalyptus trees of New Holland that I told you about some time ago; and also of some other trees of New Holland that I shall tell you about by and by, but still it makes a 
noble tree; and the tree is so straight that you may stand under the branches close to the trunk of one of these large trees, and look up to the sky, which appears gleaming above you just as if you were in a well. The spruce has a curious habit of having such of its branches as touch the ground, take root, and become young trees. Thus a circle of young trees is formed round the old tree; as curious, though not so picturesque, as those that form round the banyan tree. It is the lower branches of the spruce fir only which take root, so that the old and young trees look like a tree pegged down to make layers in a nursery; but the banyan tree sends its roots down from its upper branches, and thus forms a series of verdant arcades. Burgundy pitch, which is used for making plasters to put on the chest when people have a bad cough, is the resin of the spruce fir. An incision is made in the tree, like that I told you about in the Scotch pine; and when the resin has run out it is put into a cauldron of boiling water which melts it, and clears it from all impurities. Spruce beer is made from the young shoots of the American white spruce fir, which are boiled in water and mixed with molasses or sugar.

The Silver Fir (Picea pectinata) has flat single 
leaves with a streak of white on the under side, on each side of the midrib, and the cones stand upright on the branches. It is a noble tree, but it does not grow so high as the spruce fir, the largest silver fir we have any account of being only about a hundred and forty feet high.

The Larch (Larix europæa) is the only one of the pine and fir tribe which loses its leaves in summer. It is a native of the south of Europe, but it will grow and thrive on the coldest mountains of Scotland higher than the Scotch pine.

The Cedar of Lebanon is one of the noblest of trees. It is not very high, but its spreading branches give it an air of nobleness and grandeur. Its native country is Mount Lebanon, where every year is held a festival called the feast of the cedars. To reach the cedars, it is necessary to travel several miles up the mountain, when the traveller will arrive at a monastery of the Virgin Mary, which is situated in a valley, sunk as it were in the mountain's side. The Maronites, as the monks in the monastery are called, serve as guides to the cedars, which are several miles higher, and which grow only in one place, which is also a kind of valley in the side of the mountain. The feast of the cedars is held on the day of the transfiguration 
of our Saviour, which occurs in August, and on that day, the patriarch of the Maronites, and a number of

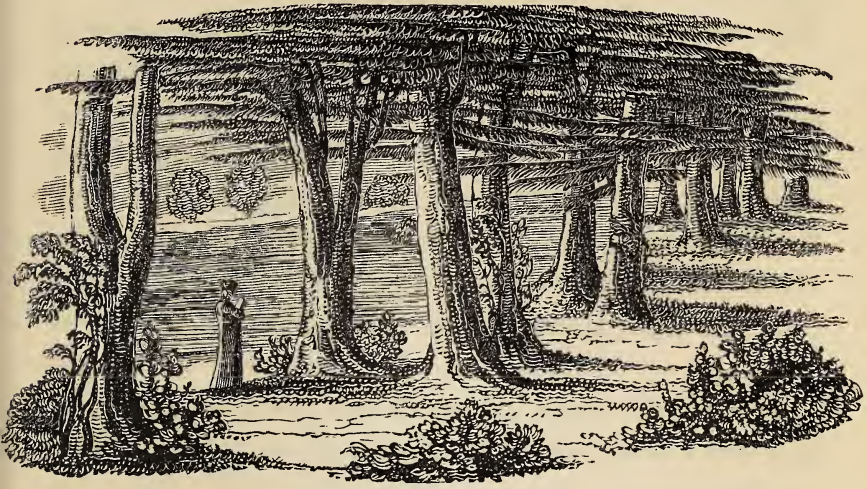

CEDAR GROVE.

bishops, priests, and monks, attended by five or six thousand pilgrims, repair to the mountain, where the patriarch celebrates high mass on an altar erected under the shade of one of the largest and oldest cedars.

This custom is still continued, as we find from a visit paid by some French gentlemen to these celebrated trees in September, 1836; but the oldest and largest trees are now in a state of decay. Nearly all 
of them bear the marks of having been struck and furrowed with lightning; and in several places rude altars of stones were found, which had been used on the occasion of the grand festivals. Besides the very old trees, some few others were found of different ages, but none apparently of less than a hundred years' growth. There was not one single young tree, and the soil being covered above six inches deep with the fallen leaves, cones, and scales of the cedars, it is almost impossible that any of the seeds which fall from the trees should reach the ground so as to germinate.

The Deodara, or Indian Cedar (Cedrus Deodara) is a still nobler tree than the common cedar. It has not been many years introduced into England, so that the trees of it in this country are but small; but in India on its native mountains, the Himalayas, it grows above a hundred and fifty feet high, with its magnificent branches spreading over a space six or eight hundred feet in circumference. There are many loftier trees in the world, but none with more widely spreading branches. The leaves of the deodara cedar are of a bluish green, and the wood, which is close and fine grained, is supposed to be the most durable in the world. I have seen a table of it, which has 
been highly polished and looks like a slab of brown marble.

The Chili Pine (Araucaria imbricata) has long slender, snake-like branches closely covered with hard thick leaves, which are placed close together, and one above another like the scales of an artichoke. The cones are very large, and each contains above two hundred seeds each nearly as big as a chestnut. The seeds or nuts are the principal food of the Araucarian Indians, in whose country the tree grows; and who live on those high South American mountains, which are called the Chilian Andes.

The Brazil Pine (Araucaria Braziliensis), is very much like the Chilian pine, but it is more tender, and less lofty. The nuts also are smaller; but they also are eatable, and they are commonly sold in the markets of Rio Janeiro.

The Norfolk Island Pine (Araucaria excelsa), is perhaps the loftiest tree in the world. It is a majestic tree growing sometimes to the height of two hundred and fifty feet, and sometimes even higher. The branches grow regularly spreading out on each side; but they have not the majesty and grandeur of those of the cedar. The trunk also is slender in proportion to its enormous height. This tree is too 
tender to stand in the open air in England, without protection; but it is a curious fact that some fossil remains have been found in Dorsetshire, which appear to have been parts of this tree. The Norfolk Island pine is only found in the warmest parts of New Holland. The Moreton Bay Pine (Araucaria Cunninghamia) is a smaller tree of the same kind, also a native of New Holland.

The Chinese Fir (Cunninghamia lanceolata); the Amboyna Pine (Dammara orientalis) ; and the New Zealand or Cowrie Pine (Dammara australis) are other trees belonging to this tribe. The latter produces a clear kind of resin, which becomes quite hard by exposure to the air. When broken it looks like coarse greenish glass, and it is found excellent for making varnish.

All these plants have their seeds in cones, which are divided into a number of scales, at the lower part of each of which there is a seed. These cones are of different shapes and sizes, but they all agree in these particulars. All these trees, except the dammaras, have what the Germans call needle leaves, that is, long and narrow in proportion to their length ; and all of them, except the larch, are evergreen. This is the first division of the cone-bearing trees, or Coni- 
feræ; and it is called Abietinæ, from abies, the spruce fir, because all the trees composing it grow tall and upright, something like that tree.

As I have thus told you all I know about the first division of the cone-bearing trees, I am now going to tell you about the second division, which is called Cupressinæ, because the trees in it all bear more or less resemblance to the cypress, which is called cupressus. Nearly all the plants belonging to this division have scaly, imbricated leaves, like those of the araucarias, but smaller; imbricated meaning that their leaves lie one over the other, like tiles on the roof of a house. The fruit of all of the cupressiniæ also is roundish, and the scales few. Among the trees belonging to this division are the American Arbor-vitæ (Thuja occidentalis), the Chinese Arborvitæ (Thuja orientalis), and the Weeping Arbor-vitæ (Thuja pendula), which the Chinese plant over their graves and monuments as the Europeans do the weeping willow; the Gum Sandarach Tree (Callitris quadrivalvis); and the common or evergreen Cypress (Cupressus sempervirens). This last is the tree which gives its name to the whole division; and it grows upright, with its branches sitting close to the stem, and tapering upwards. Its wood is supposed to be 
the gopher wood of which the ark was made, and the Egyptians made their mummy cases of it. The ancient Greeks, also, who had died for their country, had their ashes preserved in cypress, as its wood was considered more durable than any other. The Turks plant it in their burying grounds, and it is also planted in cemeteries in Europe.

The Cedar of Goa (Cupressus lusitanica) is a very elegant tree, with bluish green foliage. It is rather tender in England, it being a native of the East Indies; but it grows so well in Portugal, that some persons have thought it a native of that country.

The Deciduous Cypress (Taxodium distichum) is an American tree, which grows above a hundred and twenty feet high. It thrives best on the banks of rivers or lakes, where the points of its roots can reach the water. The roots, which spread along the ground, throw up knobs or protuberances, which are of a conical shape, and quite hollow, and which the natives use for beehives. These knobs, which are called cypress knees in America, vary in height from one foot to ten feet, and no one, as yet, has been able to explain their cause. This cypress grows principally on those marshy grounds in North America which are called the dismal swamps. These are large 
tracts of boggy ground formed by the overflowing of the rivers, in which scarcely any other trace of vegetation is found but what is afforded by these trees. The ground is too soft to walk on, and the only means of passing through this dreary region seems to be by stepping from knee to knee of the cypress. The lower part of the trunk of the tree is hollow like the knees, for five or six feet from the ground. When any of the trees in the cypress swamps near the Mississippi are to be cut down, the negroes wait till the time of the inundation, and then they get canoes, and surround the tree, cutting it down above the hollow part. The tree is then floated to the Mississippi, and down that river to whatever place may be most convenient.

The White Cedar (Cupressus thyoides) grows in the same kind of situations in North America as the deciduous cypress, but not on the same swamps; on the contrary, there are cedar swamps and cypress swamps. In the Dismal Swamp, near Norfolk, in Virginia, there are both cedars and cypresses; but even there they do not mix, the cedars being in the centre of the swamp, and the cypresses round its margin. If ever you have seen a branch of the white cedar with a cone attached to it, you will know the 
way the leaves grow in all the plants belonging to the genus Cupressus, and also the shape of the cones. The deciduous cypress has quite different leaves, but its cones are nearly the same, only smaller.

As the white cedar was a kind of cypress, so the Red Cedar (Juniperus virginiana) is a kind of juniper. It is a tree from forty to fifty feet high, a native of America; and its fruit is rather a berry than a cone. The timber of this tree is red, and a great deal of it is sent to England to make blacklead pencils, though the Bermudas cedar is preferred for that purpose. The Bermudas Cedar (Juniperus Bermudiana) is much used in the West Indies for wainscoting rooms and various articles of furniture, because it is never attacked by cockroaches or other insects. It is used in England for making blacklead pencils, and shavings of it, under the name of cedar shavings, are put into drawers to keep away moths. The tree is not common in England, as it requires protection during winter, and it has no beauty to repay so much care.

The common Juniper (Juniperus communis) is an evergreen shrub, a native of Britain and of all the north of Europe. The berries are used in making gin, which is simply a spirit distilled from corn, and 
flavoured by an infusion of these berries. The Savin (Juniperus Sabina) is also a low shrub, with a very unpleasant smell and disagreeable taste. There are many other kinds of Juniperus, natives of different parts of Europe and Asia; but I do not think there is any one peculiar to America but the Red Cedar.

\section{The Yew Tribe (Taxacea).}

There are few old churchyards in the country places of England which do not contain a yew tree. The thick foliage of this tree casts so dense a shade, that scarcely ever a blade of grass will grow below its branches, and it is one of the most gloomy of trees. The berries of the yew are red and wax-like; they are open at the top, and filled with a glutinous liquid, in the midst of which is a brown oval nut. The leaves are narrow, and of a very dark green. The yew does not grow very high; the largest $I$ ever heard of was not quite sixty feet; but the trunk is generally of great thickness.

One of the most remarkable yews in Great Britain is that at Fortingal, in Perthshire. This was a large tree in the time of the Romans; and Fortingal, which signifies the camp of the strangers, was so named because the Romans had an encampment near it. 
The tree is now a mere shell, and the funerals which take place in the churchyard which has been formed round it, pass through it. The yew trees at Fountains Abbey are also very old, as while the monastery was building there in 1132, the monks lived under the shelter of these trees, which were so large and thick, and stood so close together, as to form a very good substitute for a roof. The Harlington Yew is remarkable for the curious shape in which it used to be clipped till within the last forty years, but it is now suffered to take its natural shape.

The wood of the yew is very finely grained, particularly the root; but the great use of the wood formerly was to make bows. Before the invention of gunpowder, bows and arrows were used in battle, and the battle of Agincourt, and those of Poictiers and Cressy, were principally won by the adroitness of the English with this weapon. The bows in those days were from four to six feet long, and they were all made of yew. The arrows were best of ash, but they were made of several kinds of light wood. The bowmakers were called bowyers, and the arrow-makers fletchers. As late as Elizabeth there was a law compelling every man to practice shooting with a bow and arrow; and Newington Butts was one of the 
places where there was a butt for people to shoot at. Now the yew is very seldom used for bows, and they are made of the different ornamental woods of South America; but now they are not wanted to kill men with.

There is a kind of yew, called the Irish yew, which instead of having spreading branches, has them pointing upwards. This variety was first observed on the mountains of Fermanagh, in Ireland, but it is now grown in many places.

The Salisburia or Ginkgo tree (Salisburia adiantifolia) is a deciduous tree, with very curiously shaped leaves, which is considered to belong to the same natural order as the yew, though it is very different in appearance from that tree. The salisburia is a native of Japan, and its fruit is a nut, which is sold in the markets of Japan and China for food. It has borne fruit in France, but not yet in England.

All the plants I have hitherto told you about are called dicotyledonous. This seems a hard word, but you will not think it so when I have explained what it means. Do you remember what I told you about the lupine? Well, if you take a lupine seed, or a bean, or a pea, or a nut, or any seed that is large enough, of any of the plants I have been telling you 
about, you will find that it splits readily into two halves; and these two halves, when the plant begins to grow, turn into seed leaves, and are called cotyledons. Every one of the plants that I have been telling you about has two or more cotyledons; and dis signifies two, so that all these plants are called dicotyledonous. Now the plants I am going to tell you about have seeds which will not split naturally into two, and they have only one seed leaf; therefore as monos signifies one, they are called monocotyledonous.

All the plants that have two cotyledons have their leaves netted with veins like an oak leaf or a vine leaf ; but all the plants that have only one cotyledon have their leaves ribbed or marked only with straight veins like grass. Look! here is a leaf of grass, and here a vine leaf. See, the veins of the one are all in lines, and the other like net-work.

The trees of the two kinds also increase differently. The dicotyledonous trees are slender when young, and get thicker by successive layers of young wood, which grow on the outside of the old wood, under the outer bark; but the monocotyledonous trees are their full size when young, only they are then filled with a quantity of soft fibre, which gradually becomes 
hard wood as they get old. I do not know whether you will understand this, but it is not of much consequence at present. When you get older, and study what is called vegetable physiology, you will understand it easily. There are very few trees belonging to the monocotyledonous plants except the palms, and these I shall tell you about presently.

\section{QUESTIONS.}

1. What tree is deal the wood of ? 2. What are the resinous products of the Pine and Fir tribe? 3. What tree is Burgundy pitch made from? 4. What tree is supposed to be the loftiest in the world? 5. What genus does the White Cedar belong to ? 6. What genus does the Red Cedar belong to? 7. What use was formerly made of the wood of the yew? 8. What are all the plants called that have been mentioned previously to the end of this chapter?

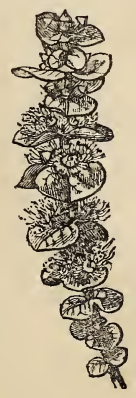




\section{CHAP. XXIII.}

THE GINGER PLANT.

THE INDIAN ARROW ROOT.

THE

NARCISSUS TRIBE.

AMERICAN ALOE.

SNOWDROP, SNOW FLAKE. CORN FLAG, IRIS. PINE APPLE. ORCHIS TRIBE. DATE PALM. COCOA NUT. SAGO PALM. CABBAGE TREE. THE LILY TRIBE, TULIPS, LILIES, ONIONS, AND GARLIC. CROWN IMPERIAL, SQUILLS, STAR OF BETHLEHEM, HYACINTHS, LILY OF THE VALLEY, ASPARAGUS, BUTCHER'S BROOM, NEW ZEALAND FLAX, THE YUCCA, AND THE ALOE.

The Ginger Tribe (Scitaminea).

THE Ginger plant (Zingeber officinalis) is a native of the East Indies, but it is cultivated extensively in the West Indies. The flowers are red, and grow out of a kind of spathe. The root is the part we use for ginger, and it is taken up when the leaves fade. That to be used as the black ginger is then washed, scalded, and afterwards dried in the sun; but the white ginger is only washed and dried without scalding. The root used for preserving is taken up before it is ripe. It is then scalded and steeped in water till it is quite tender, and afterwards put into jars, and covered with a thin syrup. 
The Turmeric (Curcuma longa) is a fleshy rooted plant, which yields a bright dye that is often used by cooks when they want to give a yellow tinge to their made dishes, as it is not at all un wholesome. It is also used for dyeing. The root of another species of the same genus (Cur cuma angustifolia) produces what is called East Indian Arrow Root.

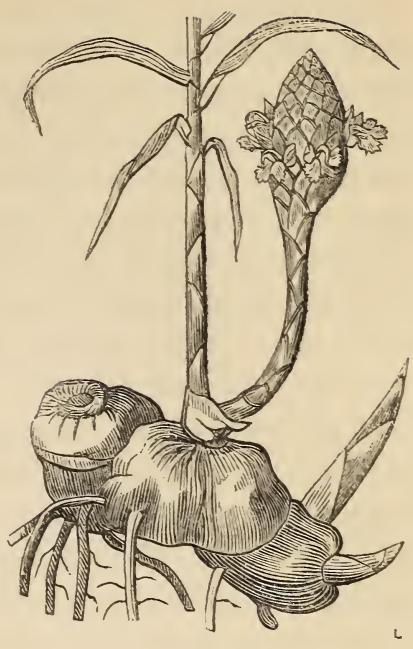

GINGER.

The most common Indian Arrow Root is, however, that made from the root of Maranta arundinacea, which, though not in the same order as the ginger, is nearly allied to it. The name of arrow root is derived from another plant of the same genus, the juice of which was taken by the Indians as an antidote to the effects of poisoned arrows. The root of the Maranta arundinacea is fleshy and tuberous. When 
taken out of the ground, it is washed, so as to free it from every particle of earth. It is then grated on a wooden grater, or pounded in a wooden mortar. The pulp thus formed is washed in water, when the flour it contains separates from the fibrous matter, and falls to the bottom of the vessel. The fibrous matter is

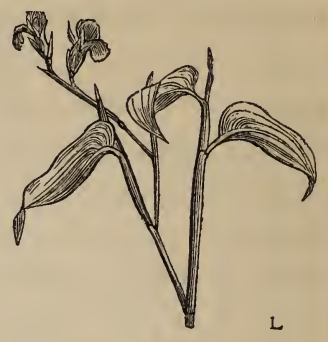

INDIAN ARROW ROOT. then removed by the hand, and the water drawn off from the sediment, after it has been suffered to remain some time to settle. The quantity of arrow root which is imported into England, amounts to four hundred thousand pounds weight every year!

The Indian Shot (Canna Indica); the Garland flower (Hedychium coronarium); the Strelitza; the Plantain tree (Musa paradisiaca); and the Banana (Musa sapientum), are all nearly allied to the Indian arrow root. The plantain and banana trees are natives of the West Indies, and they serve there at once for bread and potatoes. There is a new and most delicious fruit lately introduced into England from the Isle of France, which is called Musa Cavendishii, in honour of the Duke of Devonshire. 
The Spiderwort Tribe (Commelinacea).

The Spiderwort (Tradescantia cærulea) is a well known inhabitant of our gardens. It received its somewhat odd name, because when its leaves are broken and pulled asunder, a thread may be drawn of the sap, as fine as that of a spider. The Commelina cælestis, which belongs to the same order, has flowers of a most beautiful bright blue.

\section{The Narcissus Tribe (Amaryllidacece).}

Most of the plants belonging to this tribe are bulbous-rooted, and with very showy flowers. Among the commonest are the numerous kinds of Narcissus; of which there are above a hundred different species, besides a great number of varieties. The best known are the Poet's Narcissus (Narcissus poeticus); the Polyanthus Narcissus (Narcissus Tazetta); the Jonquil (Narcissus Jonquilla): the Hoop-petticoat (Narcissus Bulbocodium); Butter-and-eggs (Narcissus incomparabilis); and the common Daffodil (Narcissus Pseudo-Narcissus). They are all beautiful flowers; and some of them are very sweet, though their scent is said to be unwholesome. They are all natives 
of different parts of Europe ; and the common daffodil grows wild in England.

The Alströmerias, the flowers of which are generally scarlet and yellow; the Agave or American Aloe, and many other curious and beautiful plants belong to this tribe. The aloe was formerly believed to flower only once in a hundred years. This, however, is not the case, as it is found to flower sooner or later according to the treatment bestowed upon it. The flower stalk grows straight up, with branches of flowers on each side, like a candelabra. The leaf is very large and thick, and contains a quantity of succulent matter, from which starch has been made in South America. This plant has been so long grown in the south of Europe, that it has become almost naturalized; and hedges are made of it, where the climate is warm enough for the plant to grow in the open air. It is also a favourite plant in shrubberies. In the north of Italy and Lombardy, where the plant will not live through the winter without protection, they use imitations made of copper, and painted green. The genus Amaryllis contains some very handsome lily-like flowers, of the most brilliant colours. Several of these are called lilies, and they are all bulbs. 
The Snowdrop (Galanthus nivalis) is a well known British flower, which appears almost through the snow. Galanthus signifies milk flower, and nivalis means snow. It is a bulbous rooted plant, and when it comes up, the flower appears first through the ground, without any bud. There is another kind of snowdrop, a native of the Crimea, which is called Galanthus plicatus, and is much larger than the common kind. The Snowflake (Leucojum vernum) is a tall elegant flower, resembling a snowdrop. In floral language, it is the emblem of innocence, and it is dedicated to St. Agnes. The word Leucojum signifies white violet. There are several sorts of snowflake, the spring, the summer, and the autumnal.

\section{The Cornflag Tribe (Iridacece).}

The greater part of the plants composing this order, as well as the last, are bulbous rooted. The common Cornflag (Gladiolus communis) is a very showy flower, and there are some other species of the genus that have splendid flowers; one of these, the Parrot Cornflag, has its flowers curiously striped with scarlet and green.

The Iris or Flag flower is another splendid genus of flowering plants. The bulbs of one species (Iris 
Florentina), when pounded, and treated like arrow root, furnish the powder called Orrice root in the shops. The name of orrice root is indeed said to be only a corruption of iris root. The Chalcedonian Flag-flower (Iris susiana) is perhaps the finest of the genus, but there are many others very handsome. The Ixias, the Tigridia or Tiger Lily, and many other plants belonging to this order, are very ornamental; but I pass them over to come to the Crocus, which is one of the most valuable of our early flowers. You must know the crocus with all its beautiful varieties of purple and gold. The striped purple and white Scotch crocus is generally the first to make its appearance in spring, but it is soon followed by the brown and yellow cloth-of-gold. The bright yellow follows, and then come the lilac, purple, and white or cream-coloured. All are beautiful, and when they are planted in patches of a good many bulbs of the same kinds together, they look, at a little distance, when in flower, like the patterns of a Turkey carpet.

Saffron is only the dried petals of the autumnflowering Crocus (Crocus sativum), and there are large fields of this bulb grown in Essex for the purpose of making saffron. 
THE PINE APPLE.

The Pine Apple (Bromelia ananas, or Ananassa sativa) does not belong to any of the tribes I have mentioned, but to a separate one called Bromeliaceæ, though in its leaves it greatly resembles the agave. It is a native of South America, where it grows in the greatest abundance, but its fruit in a wild state is very acid, and bears but little resemblance to that of the cultivated plant. The fruit of the pine apple is in fact a head of flowers, the calyxes and

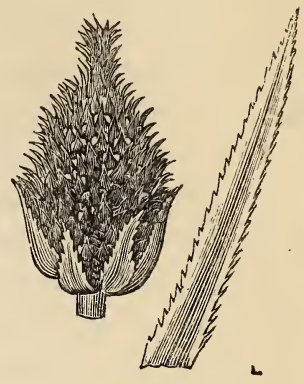

PINE APPLE IN FLOWER. bracteæ of which are fleshy, and grow together so as to form the fruit. These flowers in a wild state would have produced seed; but in a state of cultivation they are only marked in the ripe fruit by what gardeners call the pips. Here is a pine apple in flower, but in a state of cultivation the flowers drop off without producing seed; and the calyxes swell up below them, so that most persons who eat pine apples have no idea there has ever been a flower upon them. 
The pine apple plant dies when it has produced its fruit, but young plants are raised either from the crown, which grows at the head of the spike of Howers; or from suckers, which are young plants sent up from the root.

The Orchis Tribe (Orchidacea).

You may probably have seen the Wild Orchises which grow in woods in England, and may know that some of them have flowers that look as though bees, flies, or spiders, were settling in them; but these flowers, curious as they may be thought, are nothing to the wild and varied forms of the South American and Mexican Orchidaceæ. These plants generally grow on trees, with their roots hanging down in the air; and their flowers not only present the most extraordinary forms, but the brightest, and most varied colours. It would be in vain to attempt to tell you their names, for there are above a hundred different genera, and I do not know how many species in each; but I must mention one, Vanilla aromatica, because its dried fruit is frequently mixed with chocolate, and several kinds of sweetmeats are made of it. This little plant is not properly one of the orchidaceæ, but it is very nearly allied to them, and 
like most of them, it is what is called an epiphyte, that is, its roots grow in the air, and not in the ground.

\section{The Palm Tribe (Palmacece).}

The Date Palm (Phœnix dactylifera) is preeminently the tree of the desert, as it will grow where no other tree is to be seen. It does not rise very high, seldom exceeding forty feet, and never being higher than sixty feet; but travellers have described it as of enormous height, and towering to the skies, because they have seen it growing where there were no other trees to compare with it. Besides this, the habit of growth of the date palm gives the idea of a lofty tree, from its straight, simple, scaly trunk, which rises to its full height without a branch, and is crowned at the top with a spreading tuft of large leaves. These leaves are very large, being frequently ten or twelve feet in length; and the fruit is produced in large clusters, weighing from twenty to thirty pounds each. You have no doubt tasted dates, and know that they are very good to eat, but you can have no idea of the value they are of to the inhabitants of the desert. They have no other fruit tree, they have no corn, and no vegetables, and the dates serve them as a substitute for all these important articles of food. The dates 
require no preparation except drying, to fit them for a foreign market. When the seed or stone of the date is burnt, its soot is used by the Chinese in making Indian ink. The wood of the old trees is very hard, and is used for building; and the leaves, after having been soaked in water, are manufactured into hats, mats, and baskets. The petioles afford fibres, from which ropes are made ; and the sap is made into wine. The Cocoa-nut Palm (Cocus nucifera) is found in all the tropical regions growing on the verge of the sea, and even on reefs and sand banks, as soon as they emerge from the ocean. The tree rises like a lofty column, eighty or ninety feet high, with its slender trunk marked with numerous rings, that are produced by the remains of the footstalks of the leaves, which fall off annually. The crown on the summit consists of twelve or fifteen leaves, each fourteen or fifteen feet long. The flowers proceed from a kind of spathe, like that you saw the flowers come from of the ginger; and as soon as the nuts begin to form, fresh flowers are produced; so that during the wet season, this tree is always in flower, and always in fruit.

The uses of the cocoa nut tree are almost innumerable; the roots are chewed like tobacco, the trunk 
of the old tree is useful for its timber, and that of the young tree for any purposes for which hollow tubes are required; the young buds make an excellent vegetable; the leaves are used for thatch, and for manufacturing pails, baskets, hats, and numerous articles of clothing, and even paper, the midrib serves as oars for rowing boats with, and the point of the leaf bruised for making brushes. From the sap, sugar is procured, by boiling and drying; palm wine is also made, and arack distilled from it; from the pith of the young stem a kind of sago is made; and the fibrous bark is employed to make cordage, and also to stuff mattrasses. The outer husk is used as a basket, and the shell as a drinking vessel; the milk is very nourishing, and the nut is not only good to eat, but by pressure it yields an excellent oil.

The name cocoa is said to be taken from macaco, the Portuguese word for a monkey, from the curious marks like eyes and mouth on the cocoa nut. These marks are the places through which the young shoots from the seed would be protruded. As only one of them, however, is generally wanted, this one may be known by pricking it with a pin, as it is soft while the others are quite hard. Thus wisely has our great Creator provided for the protection of the 
germ of the young tree. He has encircled the seed with moisture to preserve its vitality in the burning climate in which the tree grows, if the nut should fall on land; and He has enclosed it in a hard shell to protect it, in case it should fall in the water, or against the rocks, providing a place where the young and tender shoot may break through, as it could not penetrate the hard part of the shell.

The Sago Palm (Sagus Rumphia) is a tree somewhat resembling the common date palm. It grows wild in the East Indies. The sago is made from the pith washed in water, and then rubbed through a coarse cloth. The substance is then placed in a shallow saucepan over a slow fire, and stirred constantly till all the moisture is evaporated. The rubbing through the cloth, and subsequent stirring, break it into grains about the size of peas; and it is in this state when it is bought in the shops.

There are many other kinds of palm trees, but they all agree in the straight trunk free from branches, and the crown of leaves. The fan palm has fanshaped leaves, and this, which is the hardiest of the species, is found in abundance on the shores of the Mediterranean. The others will only grow in the open air within the tropics. The cabbage palm, men- 
tioned in Paul and Virginia, has a very slender stem not more than six inches in diameter in the thickest part, though it is sometimes a hundred feet high. The cabbage is formed by the young undeveloped leaves in the centre of the expanded tuft. It is tender, and when cooked it forms a most agreeable food. When it is gathered, the slender trunk must be broken off near the root, to obtain the cabbage at its summit.

\section{The Lily Tribe (Liliacea).}

Who would suppose that the Tulip and the Lily belonged to the same natural order as the Garlic? But it is so, and more, botanists comprise in the same order the Asparagus, the Crown Imperial, the Agapan thus, Squills, the Star of Bethlehem, the Hyacinth, the Lily of the Valley, Butcher's Broom, New Zealand Flax, the Yucca, and the Aloe.

How shall I attempt to describe these plants to you? The tulips and lilies would themselves occupy many days. You know that they are bulbous rooted plants, and that the tulips have as many names as they have colours. All the tulips grown by florists are varieties of one species, Tulipa Gesneriana; except the yellow tulip, which has a sweet scent, and is 
called Tulipa sylvestris, and the little highly coloured tulips which are grown in pots early in spring, and are called Van Thol tulips, (Tulipa suaveolens). The parrot and double tulips are varieties of Tulipa Gesneriana, but they are not valued by florists; neither are the self-coloured kinds. The only tulips a florist thinks worth growing, are those with tall upright stems, and cup-shaped flowers, clearly and distinctly marked, and quite white in the centre. Of these perfect tulips there are five distinct sorts. Prime Baguettes, very tall upright stems, with flowers marked with brown on a white ground; Baguettes Rigaut, similar to the former, but not so tall ; Incomparable Verports, cherry or rose on a white ground; Byblomens, dark purple or white, and very large flowers; Roses, rose-coloured on white merely edged; and Bizarres, dark stripes on yellow.

The lilies are not so numerous in their varieties, but there are many distinct sorts. The Martagon lilies, or Turk's caps, and the common lilies are, however, the only distinct shapes; and all the other kinds merely vary in the size and colour of their flowers.

The Crown Imperial (Fritillaria Imperialis), and the common Fritillary (Fritillaria Meleagris) are 
common garden bulbous-rooted flowers. The first is remarkable for the little drops of water that remain without falling in the bell of each flower; and the latter for its chequered or chess board appearance inside. There are several varieties of fritillary, and they are all curious looking flowers: they will all grow well in the shade of trees.

The Garlic (Allium sativum) is a bulbous-rooted plant with a very strong smell; it is well known for the use made of it in seasoning. The common onion belongs to the same genus, and its botanical name is Allium Cepa. Chives are called Allium Schœnoprasum; and Leeks Allium Porrum. The shallot is Allium ascalonicum. All these useful plants belong to the same genus; and it is the bulbous roots of all of them that are used for food. There are many other kinds of Allium some of which are handsome garden flowers, but all of which have more or less of a strong smell of garlic, when gathered.

The Agapanthus, or African Lily, is a beautiful blue flower. Its botanic name of Agapanthus signifies lovely flower, and I think it is well named. The Hemerocallis or Day Lily is another beautiful plant, with ribbed leaves, and elegant flowers.

The Squills (Scilla italica) are beautiful flowers a 
good deal like those of the hyacinths. Scilla nonscripta is the other harebell of the woods, that I told you about when we spoke of the Campanula rotundifolia, or bluebell. Scilla Peruviana is a magnificent flower. The Star of Bethlehem or Ornithogalum is very nearly allied to the squills. In fact, though they may be easily known asunder, there is scarcely any botanical difference. The medicine called Oxymel of Squills, is made from the root of Ornithogalum Squilla.

The Lily of the Valley (Convallaria majus) and Solomon's Seal (Polygonatum multiflorum); are both elegant looking plants with bell-shaped flowers; and both grow wild in Britain in woods and shady places. The lily of the valley is most abundant in the woods near Woburn in Bedfordshire; and it is from that county that the London market is supplied. Nothing can exceed the delicious fragrance of this flower when fresh, but it loses its sweetness when it is dried. Solomon's seal takes its odd name from its roots, which when cut in two present some curious marks that look like letters, and have thus been compared to the characters on Solomon's seal.

The garden Hyacinth (Hyacinthus orientalis) is a flower of which there are said to be two thousand 
varieties. I cannot pretend to tell you the names, for I do not know a tenth part of them; and there are no great divisions of them as there are of the tulips, and carnations. The colours of the hyacinths are white, blue, and red ; some are single, some semidouble, and some double. The white are reckoned most beautiful when they are dark in the centre. The Grape Hyacinth (Muscari botyroides) is a curious looking flower, the summit of the spike of which looks like a tassel.

The Asparagus grown in gardens (Asparagus officinalis) is a native of Britain, and grows wild on the sea-shore. Its young shoots in this wild state, are, however, too tough, and too slender to be eaten. It is grown for the table, by planting it in beds deeply trenched and richly manured; and this treatment renders it thick, succulent and tender. It has a very long tap root, that is a root that goes straight down into the earth; and it is curious to see gardeners trenching the ground to the depth of four feet for this little plant, while they make a bed only one foot six inches deep for a large peach tree; for all fruit trees have spreading roots, and they never thrive unless their roots are near the surface of the ground. There are several sorts of asparagus, which are grown 
in Italy as ornamental shrubs, but they are not common in Britain.

Butcher's Broom (Ruscus aculeatus) has the very strange habit of producing its flowers and fruit in the middle of its leaves. This is the common kind, which is called Butcher's Broom, because butchers used formerly to tie bunches of it together, to keep the flies away from their meat. The Germans call it Mouse Thorn for nearly the same reason; for they put it in their pantries over cold meat to keep

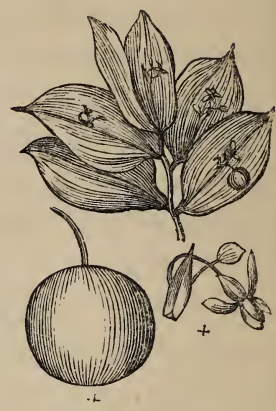

BUTCHER'S BROOM. away the mice. The leaves of the plant are very sharp pointed and prickly, and when the mice come near it they prick their noses and run away. There is another kind of Ruscus, a climbing plant that bears its flowers round the margin of its leaves. The climbing plants called Smilax, the fleshy root of one of which produces the sarsaparilla; the black Bryony (Tamus communis); the Yam (Dioscorea sativa), which serves instead of both bread and potatoes to the negroes in the West Indies ; the Elephant's Foot, or Hottentot's Bread (Testudinaria elephantipes), 
the root of which is eaten by the Hottentots ; the different kinds of Arum; all belong to this tribe.

The Yuccas are large aloe-like plants with tall spikes of bell-shaped flowers. There are many different kinds, but Yucca gloriosa, or Adam's Needle, is the most common. You must take care not to hurt yourselves with the points of the leaves of this plant, for they are very hard and strong. The aloes are plants very similar to the

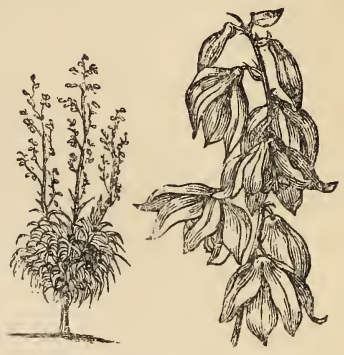

YUCCA OR ADAM'S NEEDLE. yuccas, but with differently shaped flowers. The drug called aloes, is made from the juice of the leaves of Aloe soccotrina. The leaves are cut off close to the stem of the plant, and placed in large tubs. A great quantity of juice runs from them, and the remainder is pressed out. This juice is afterwards boiled or set in the hot sun, and in either case, it depo sits a sediment, which is the

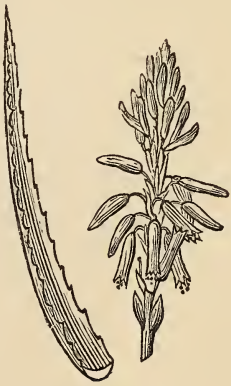

BITTER ALOE. 
drug called Aloes. The New Zealand Flax (Phormium tenax) belongs to the same division of Liliaceæ as the aloe. It is the fibrous part of the leaves that is used to make cordage.

\section{QUESTIONS.}

1. What part of the ginger plant is the ginger? 2. What natural order does the Snowdrop belong to ? 3. What plant produces saffron? 4. What are the principal plants belonging to the natural order Iridaceæ ? 5. What is the fruit of the pine apple composed of ? 6. What is remarkable about the flowers of the Orchis tribe? 7. What are the principal products of the Palm tribe? 8. What are the principal plants belonging to the Lily tribe?

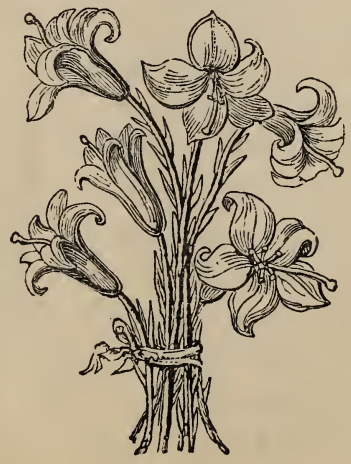




\section{CHAP. XXIV.}

THE GRASS TRIBE, INCLUDING WHEAT, RYE, BARLEY, OATS, INDIAN CORN, MILLET, RICE, THE SUGAR-CANE, THE BAMBOO. AQUATIC PLANTS. RUSHES, DUCKWEED, ETC. MOSSES, FERNS, LICHEN, SEAWEED, AND FUNGI.

\section{The Grass Tribe (Graminea).}

THE most important of all the monocotyledonous plants are included in the Grass tribe. Important, you will perhaps say, they may be to horses and cows, but what have we to do with them? Much more than you imagine. This class of plants includes all the kinds of corn, the rice, and the sugar-cane, besides many other very valuable plants.

The plants which supply corn are called by botanists the cereal grasses. They are Wheat (Triticum æstivum), Rye (Secale cereale), Barley (Hordeum vulgare), Oats (Avena sativa), and Maize or Indian Corn. Of these, wheat is the most valuable, as its grain, when ground, affords by far the greatest quantity of flour, and this flour makes the most nourishing bread. There are a great many different kinds of wheat; but in England the sorts generally sown are the spring wheat and the winter wheat, the latter 
being the kind most depended upon for the crop. The ground on which wheat is to be sown requires a great deal of ploughing, as wheat succeeds best on strong firm land. When the land has been ploughed, and ploughed again, and harrowed, the seed is sown either by a man walking all over the field with a box strapped before him, and throwing the seed out of it by handfuls, which is called broadcast; or by a machine, into which the seed is put, and which being drawn across the field, sows the seed in straight lines, which is called drilling.

When the wheat is ripe, it is cut by persons called reapers, who hold a handful of stalks in one hand, while they cut them through below with a sharp hooked knife, called a reaping-hook or sickle. Each handful of wheat as it is cut is laid on the ground in heaps, with the heads all the same way; and then it is tied in large bundles, which are called sheaves, and set one upon another till they are dry. Then the corn is carried home, and either made into a stack or put into the barn till it can be thrashed. Thrashing is beating the heads of corn either with two sticks fastened together with a piece of leather, and called a flail, or with a thrashing machine. When the grains are thus separated from the straw, they are 
winnowed, by passing over them a machine like a small windmill, which blows away from them the little bits of straw and husks that were among the grains, and which are called the chaff. The wheat is then ground between two stones in a mill, and the husky part, which is the bran, is separated from the flour, by brushing the latter through a fine sieve that the bran cannot pass through.

The straw of the wheat is principally used in England for thatching, and for making beds for horses and cows; but it is also used for making bonnets. The best straw for this purpose is that grown on dry chalk; and thus the best bonnets are made at Dunstable, which is surrounded by chalk hills. The Leghorn bonnets are made of a very fine-stalked wheat, quite different to the common kind. It is cut green, and bleached by laying it for a long time in the river Arno, which has a gravelly bottom. This fine straw is plaited without splitting it, and this is the reason the Leghorn bonnets are so strong.

Rye and Indian corn are reaped like wheat, but barley and oats are mown like grass. Barley is used in England principally for feeding poultry and for making malt. For this last purpose the barley is steeped in water till it begins to grow, and then it 
is put upon what is called a kiln, under which is a stove, and dried. This shrivels up the young shoot, and the barley is now become malt. Oats are used for feeding horses, and also for making oatmeal, which is used for making oat cake, gruel, \&c. Indian corn seldom ripens in England, but a great deal of it is grown in America, where they eat a delicious dish called homminy, made from it, as furmety is from unground wheat.

Millet (Panicum milliaceum), and Rice (Oryza sativa), are two other plants belonging to this order, which form important articles of food. Rice is particularly valuable. This plant differs from all the bread corns in requiring to be grown almost in water; that is, the ground it is grown in must be kept covered with water, while the plants are growing. As soon as the grain has swelled, the ground is suf-

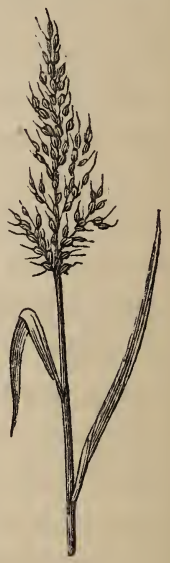
fered to dry, so that when it is cut down the reaper stands on dry land. It is afterwards dried, and thrashed like corn, and there is a reddish skin on each grain, which is taken off by passing it between 
two flat stones in a kind of mill, before it is fit for sale. Both rice and millet are grown in Italy. A great deal of rice is grown in the East Indies, where the Hindoos call it paddy; but the best rice is that grown in Carolina, in North America.

The Sugar-cane (Saccharum officinale) is merely a kind of grass or cane full of an extremely sweet juice. A plantation of sugar-canes in the West Indies sends up every year shoots from six feet to ten feet long. These are then cut off, and carried to the mill. This mill merely consists of two iron róllers, between which the canes are pressed till all the juice runs from them. This juice is then mixed with quicklime and boiled. All the impurities rise

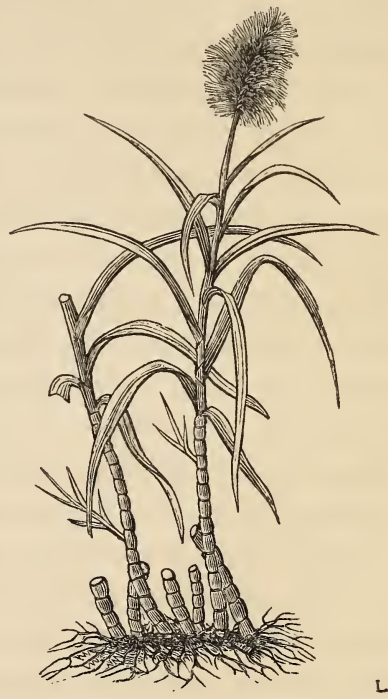

SUGAR-CANF, to the surface, and are carefully skimmed off. When 
sufficiently boiled, the syrup is put into what is called a cooler, and stirred with wooden instruments to break the crust that forms on the surface. It is afterwards poured into casks, which have little holes bored in the bottom stopped with cane. The syrup which is not condensed filters through these canes, and leaves the sugar behind. The syrup is the molasses or treacle, and the sugar, the common coarse brown sugar of the shops. This sugar is afterwards refined by adding various substances to it; and the lump sugar is cleared and whitened by the addition of bullock's blood, plaster of Paris, eggs, and other things. You must not suppose that these things remain in the sugar; on the contrary, they combine with the impurities which the sugar contains, and when the sugar is boiled, they rise to the surface in the form of scum. This sugar-bakers' scum, as it is called, is the richest of all manures for plants, and it is used by florists for their prize auriculas. Sugar-candy is formed by boiling sugar in water till it begins to crystallize, and then dipping threads in it. Part of the sugar crystallizes round the threads, and the remainder is run into moulds, and forms barley-sugar. Rum is distilled from the molasses, or from coarse sugar and water. 
The Bamboo (Bambuca arundinacea), of which canes and bamboo seats are made, and the Calamus, of which rattan canes are made, and which the ancients used for their pens, also belong to this tribe; as do many other interesting plants.

I shall only now say a few words on the grasses. When you walk across a meadow, and see it covered with grass, you little suspect the amazing number of sorts of grass that contribute to form the verdant carpet beneath your feet. The commonest grass is the Poa annua; but there are, among many others, the Rye Grass (Lolium perenne), the Quaking Grass (Briza media), the Dog's-tail Grass (Cynosurus cristata), the Cock's-foot Grass (Dactylis glomerata), the pasture grasses, particularly that of which sheep are so fond, Festuca ovina, the Feather Grass (Stipa pennata), the Cat's-tail Grass (Phleum pratense), the Bent Grass (Agrostis vulgaris), the Fox-tail Grass (Alopecurus pratense), and many many others. These names will give you an idea of the wonderful number of things that there are in nature that we pass by without seeing; and of the advantage of knowledge in increasing our means of enjoyment. The person who knows nothing of plants walks across a grass field, without feeling the slightest interest in 
it, further, perhaps, than that the grass is more agreeable to the feet than the dusty road; but the botanist finds amusement and delight in every blade of grass, and with every plant that he examines he feels his heart expanded with wonder and gratitude to the Great Creator of all he sees.

AQUATIC AND MARSH MONOCOTYLEDONOUS PLANTS.

The Flowering Rush (Butomus umbellatus) is a common water plant in England. The stem resembles that of a rush, and it has a large spreading umbel of deep rose-coloured flowers. The Water Plantain (Alisma Plantago) is another British plant. It has rather large, broad, ribbed leaves, and white flowers. Both this plant and the flowering rush are said to be remedies for the hydrophobia.

There are also numerous kinds of rushes. The Dutch Rush (Juncus acutus) is so rough that it is used for polishing copper and other vessels, and is of essential service in Holland in keeping the banks together, which have been erected to keep out the sea. This rush, and some other kinds, are planted on the top of the banks, and their long roots run down through them, and become matted together so 
firmly as to hold up the bank. The common British rushes (Juncus conglomeratus, and Juncus effusus) are used to make mats, rush baskets, and the bottoms of chairs. They are also used as the wicks for rushlights, and were formerly employed for strewing on floors before the invention of carpets. They are still used for that purpose in Poland; and I have dined at the table of a Countess in that country, where the floor was covered with a kind of rush (Acorus calamus), which is very fragrant when trodden on.

The Bullrush tribe (Typhaceæ), the Sedge tribe (Cyperaceæ), and the Duckweed tribe (Pistiaceæ), are three other tribes of water plants. The Duckweed (Lemna minor) grows in great abundance on stagnant water, and each leaf has a separate root. Ducks eat this plant greedily, and gold fishes are said to be very fond of it.

THE MOSSES, THE FERNS, THE LICHENS, THE SEAWEED, AND THE FUNGI.

The Mosses, when closely examined, are as curiously contrived for producing their seed, as the noblest plant I have told you of. The humble moss upon the wall is as admirably adapted for its situation, and the purposes it was intended to answer, as the loftiest 
forest tree. The ferns are equally interesting. Neither of these tribes produce flowers, but their seeds are beautifully constructed and protected. The ferns were long thought to have no seed, but it is now known that the little brown patches on the under side of the leaves, which appear in spring and are ripe about August, contain the seed.

The Lichens are the little moss-like plants, which grow on dead wood, and sometimes also on rocks and stones. Some are rather larger and more important, such as the Reindeer Moss (Cenomyce rangifernia), Iceland Moss (Cetraria islandica), and Orchil (Roccella tinctoria). The Seaweeds (Algæ) are a host in themselves: humble as they seem in the scale of creation, they are not less wonderful in their construction than the other plants; and even those which are so small and fine as to require a microscope to see them, afford, when examined, only new proofs of the power and goodness of God.

The Sponge, which was long supposed to be the work of an animal, is now discovered to be vegetable, and to produce a sort of seed; and the water, like the land, teems with wonders, did we but know in what manner to discover them.

The Fungi are the last plants that I shall tell you 
about. You know the common Mushroom (Agaricus campestris), but you probably do not know the curious manner in which it is grown. When manure has lain in a heap together for a long time in a dry place, some little white threads are occasionally perceived to run through it. These little threads are the mushroom spawn. They are not found in all manure, but when they do occur, if they are placed by gardeners in a bed properly prepared, and kept covered with straw, in a warm place, they will soon produce mushrooms. Several plants belonging to the genus Agaric are poisonous, so that it is always dangerous to eat mushrooms found in the field, unless you are quite sure that they' are the right sort.

The most curious fungi, however, are those that are found on plants, and some of which are vulgarly called blight or mildew. I have already mentioned the mildew to you, and I will now describe to you two kinds, the barberry mildew, and the mildew on the bean and pea. The latter (Uredo Fabæ) looks as though a little whitewash had been thrown accidentally on the leaves affected; but when examined closely, it will be found to consist of a mass of slender white roots curiously interlaced. From these spring a number of little shoots, each bearing a ball- 
like head, which when ripe bursts and discharges seed. The Barberry Mildew (Ecidium Berberidis) looks like rust upon the leaf; but when magnified, it will be found to consist of a number of small orange cuips with a film over each. When ripe, the lids burst, and the top of the cups assumes a ragged uneven appearance; each cup has within it a great number of very, very small boxes, each full of seed. Even the cups are so small as not to be seen without a powerful microscope; and the boxes look like a fine orange powder, as fine as flour between your fingers; and yet every seed that they contain is as perfect, and as fully competent to fulfil the uses for which it was designed, as the largest nut. Such are the wondrous works of God! And so far does His power surpass even the comprehension of man! When I think of these things, and when I see opening at every step fresh subjects of astonishment and admiration, I feel my own weakness, and my utter incompetence to explain to you a tenth part of the miracles by which you are surrounded. I cannot explain to you the wonders of creation; I can only point the way which you may pursue, satisfied that at every step you will find more and more to admire, and more and more to show you the 
immense superiority of the humblest works of God, over the most highly finished works of man. And yet this great, this omnipotent Being, has kindly promised to listen to us when we call upon Him, and has encouraged us to lay all our sorrows at His feet and promised that He will comfort us. Let us then offer up our prayers to Him with deep humility and consciousness of our own unworthiness; but at the same time with perfect confidence in His mercy and goodness; for $\mathrm{He}$ who has bestowed so much care on the very weeds which we trample under our feet, will not despise the prayers of those creatures whom He has created in his own image. Old and feeble as I am, I feel a glow of comfort and happiness spread through my frame, when I think on this subject. I did not forget my Creator in the days of my youth, and $\mathrm{He}$ does not neglect my old age.

And now, my dear children, think of what I have told you. We have passed together many happy days, and I have told you many curious things. May they sink deep into your minds, and may they encourage in you a love for simple and innocent pursuits. Every year when the first breath of spring warms the air, and the timid snowdrop and winter aconite first peep above the ground, may you think of the old 
man who is now addressing you, and remember his lessons.

\section{QUESTIONS.}

1. What natural order does wheat belong to? 2. What other important plants belong to that order? 3. What are aquatic plants? 4. What is the Dutch rush used for? 5. What is the mildew on the leaves of plants?

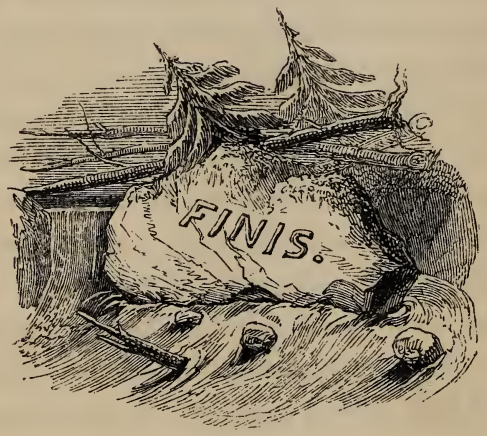

CHISWICK PRESS :

PRINTED BY C. WHITTINGHAM. 




\title{
P059521
}

\author{
Library \\ of the
}

University of Toronto

$\int_{1}^{1}$ 


$$
\text { is }
$$

